Portland State University

PDXScholar

\title{
Multi-Stakeholder Collaborative Learning and Action Precesses for Social Change and Sustainability: The Case of a Regional Food System Effort in the Pacific Northwest
}

Janet Michelle Hammer

Portland State University

Follow this and additional works at: https://pdxscholar.library.pdx.edu/open_access_etds

Part of the Urban Studies Commons

Let us know how access to this document benefits you.

\section{Recommended Citation}

Hammer, Janet Michelle, "Multi-Stakeholder Collaborative Learning and Action Precesses for Social Change and Sustainability : The Case of a Regional Food System Effort in the Pacific Northwest" (2007). Dissertations and Theses. Paper 5805.

https://doi.org/10.15760/etd.7676

This Dissertation is brought to you for free and open access. It has been accepted for inclusion in Dissertations and Theses by an authorized administrator of PDXScholar. Please contact us if we can make this document more accessible: pdxscholar@pdx.edu. 
MULTI-STAKEHOLDER COLLABORATIVE LEARNING AND ACTION PROCESSES

FOR SOCIAL CHANGE AND SUSTAINABILITY:

THE CASE OF A REGIONAL FOOD SYSTEM EFFORT IN THE PACIFIC NORTHWEST

$$
\text { by }
$$

JANET MICHELLE HAMMER

A dissertation submitted in partial fulfillment of the requirements for the degree of

DOCTOR OF PHILOSOPHY

in

URBAN STUDIES

Portland State University

2007 


\section{DISSERTATION APPROVAL}

The abstract and dissertation of Janet Michelle Hammer for the Doctor of Philosophy in

Urban Studies were presented May 11,2007, and accepted by the dissertation committee and doctoral program.

COMMITTEE APPROVALS:

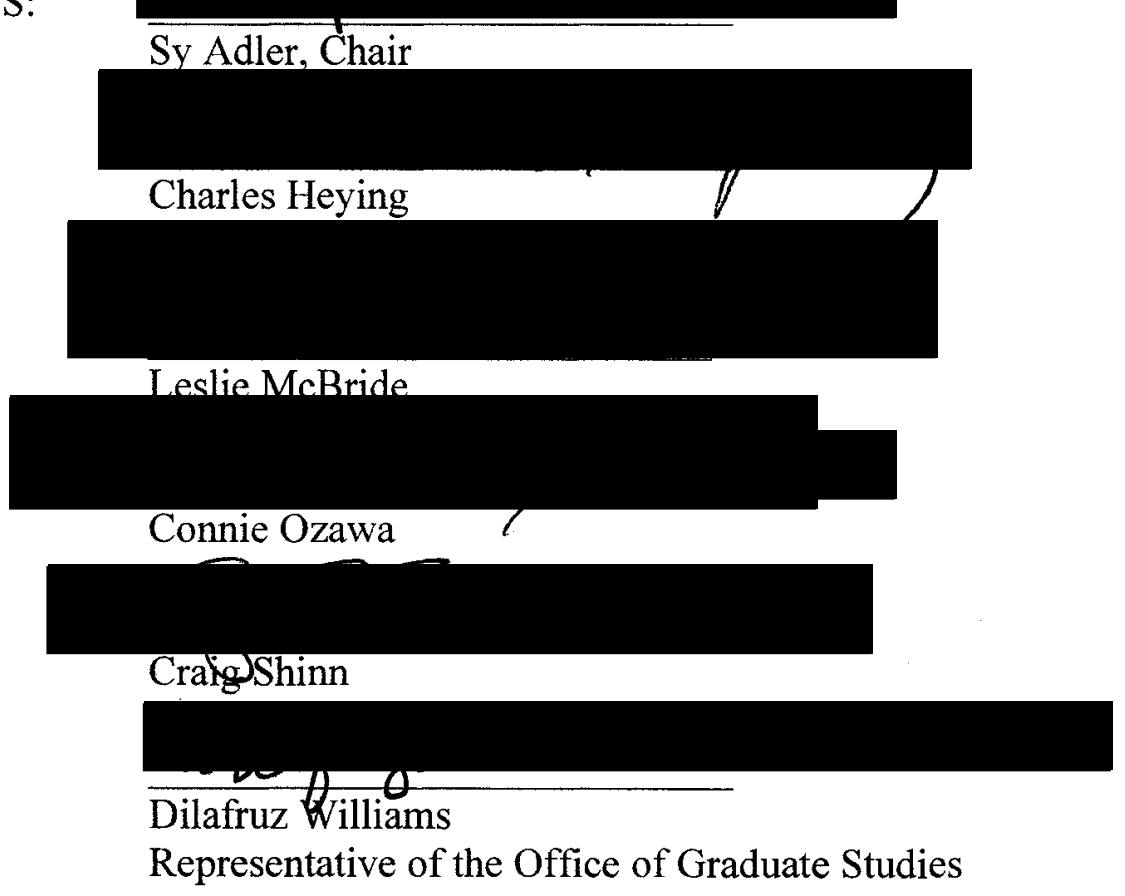

DOCTORAL PROGRAM APPROVAL:

Tony Rufolo, Director

Urban Studies Ph.D. Program 


\begin{abstract}
An abstract of the dissertation of Janet Michelle Hammer for the Doctor of Philosophy in Urban Studies presented May 11, 2007.
\end{abstract}

Title: Multi-Stakeholder Collaborative Learning and Action Processes for Social Change and Sustainability: The Case of a Regional Food System Effort in the Pacific Northwest

Multi-Stakeholder Collaborative Learning and Action (MCLA) is defined as a type of multi-stakeholder process that convenes diverse system members for the purpose of increasing individual and system knowledge and facilitating individual and collaborative activity supportive of movement toward a shared vision or goal. Despite increased theoretical and practitioner attention to the topic, questions remain regarding what reasonably to expect from MCLA processes and how best to design them. Further, little research has addressed the assertion that certain MCLA processes can facilitate domain development. Addressing these questions, this case study applies quantitative and qualitative methods to the analysis of two components of a MCLA process: a large group intervention and an interorganizational collaborative alliance. A range of direct and indirect, tangible and intangible effects was identified at individual and domain levels. Examples include increased understanding about domain issues and partners, new and enhanced relationships, knowledge transfer and 
creation, belief and value clarification, behavior and programmatic change, improved collaborative capacity, and sense of inspiration or connection.

This research confirms the effectiveness of whole systems, participatory, and dialogic design principles, as well as the importance of attending to diverse learning styles and establishing a positive tone. Research questioning the reasonableness of expectations for self-organization regarding both action agendas and collaborative alliances is affirmed.

With respect to domain development, this research confirms that large group interventions can facilitate problem setting, direction setting, and/or structuring. Further, they can foster the system appreciation, networks, and shared vision identified as important to domain development. The importance of referent or bridging organizations is validated, though difficulty structuring such alliances is also confirmed.

MCLA processes are identified as valuable to community and movement development and adaptive governance. A positive but qualified assessment is provided regarding expectations for the potential of MCLA processes to support social change and sustainability. This research advances understanding of likely effects and key design considerations regarding MCLA, however, questions remain pertaining to stakeholder participation, dominant discourses, engagement practices, the role of referent organizations, effect measurement, comparability and appropriate use of various processes, and support of sustainability and social change. 


\section{ACKNOWLEDGEMENTS}

There are so many people who have contributed to making this dissertation possible. To each of you I offer my sincerest gratitude. Thanks especially:

To the Community Food Matters participants, for their commitment to inquiry and action in support of sustainable food systems;

To my financial patrons, for the assistance that helped make this action research possible;

To the librarians, for skillfully and cheerfully accommodating my requests;

To the practitioners and scholars whose work informed and shaped mine;

To my committee members, who encouraged and inspired me;

To Sy, for his guidance and unwavering support;

To my family and friends for their love, faith, and generous assistance...

Thank you for believing in me and in the hope that this work may serve to help bring about a more joyous, sustainable world for current and future inhabitants of this island we call home. 


\section{TABLE OF CONTENTS}

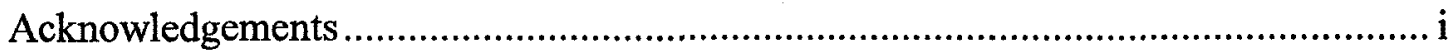

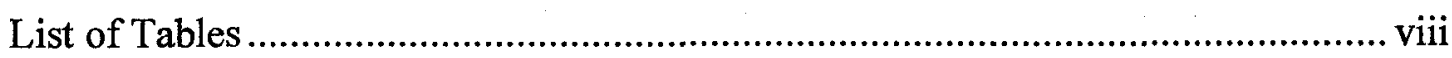

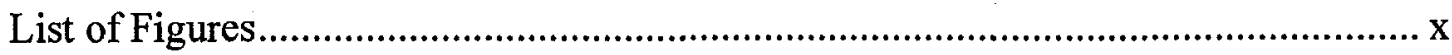

Chapter One: Introduction and Literature Review................................................. P. 1

Multi-stakeholder Processes ............................................................................... P. 1

Multi-stakeholder Processes and Domain Development.................................... P. P. 4

Multi-stakeholder Collaborative Learning and Action ...................................... P. 5

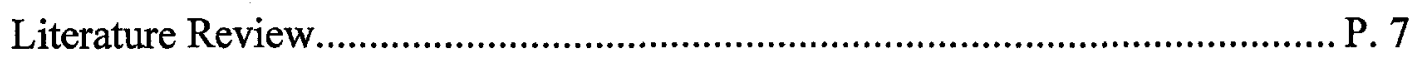

Contributions of this Research................................................................ 15

Chapter Two: Case Description....................................................................... P. 17

Prologue to the Case .................................................................................. P. 17

Birth of Community Food Matters................................................................... P. 19

The Large Group Intervention (Forum) ………............................................ P. 21

Identifying a Home, Structure, and Purpose for the Collaborative Alliance....... P. 24

The W.K. Kellogg Foundation Concept Paper .................................................. P. 28

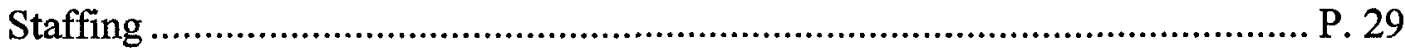

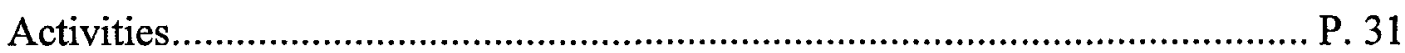

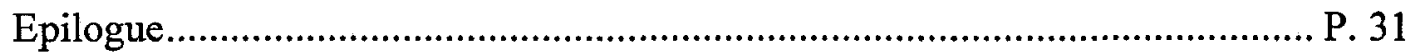

Chapter Three: Research Design and Data Considerations..................................... P. 32

Research Standpoint ............................................................................... P. 32

Research Questions ................................................................................. P. 33 


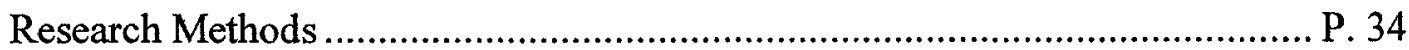

Baseline and Follow-up Survey ................................................................. P. 35

Forum Survey .................................................................................. P. 49

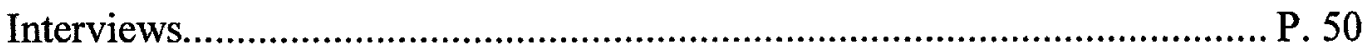

Documents and Archival Data.............................................................. P. 52

Participant Observer Notes ................................................................... P. 52

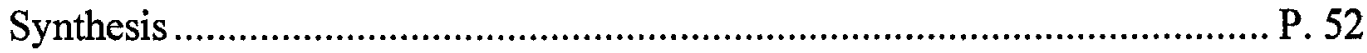

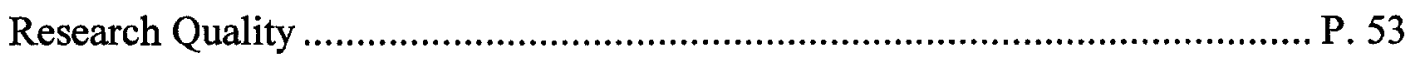

Chapter Four: Case Effects............................................................................. P. 58

Substantive Learning ............................................................................... P. 59

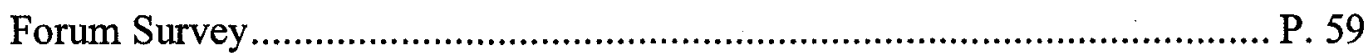

Survey One-B (Follow-up Survey) …………………………................... P. 62

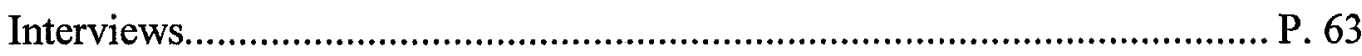

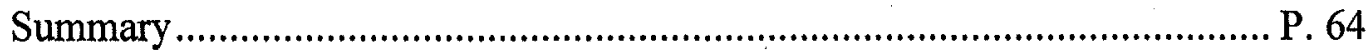

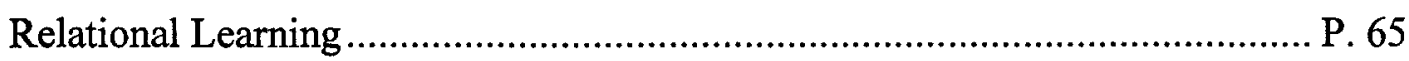

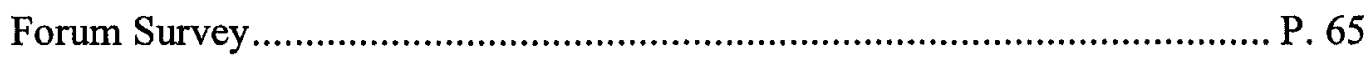

Survey One-B (Follow-up Survey) …………………….......................... 67

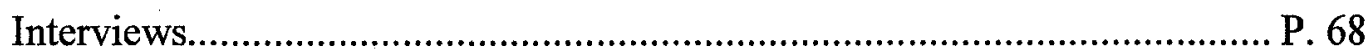

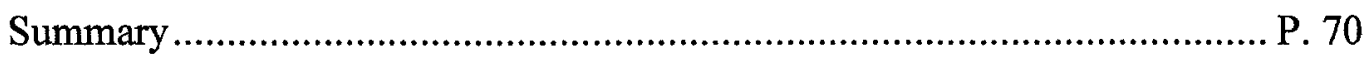

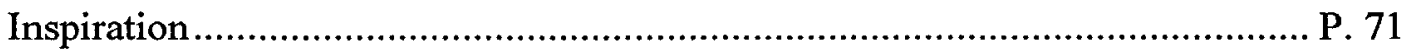

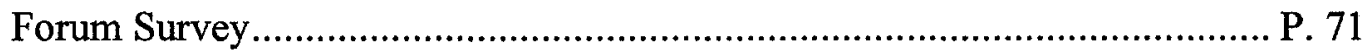

Survey One-B (Follow-up Survey) …………………........................... P. 72 


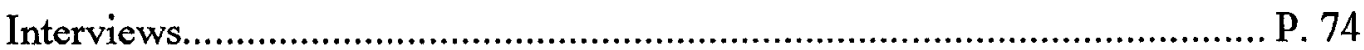

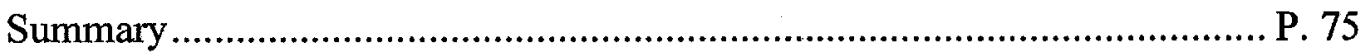

Viewpoint Change.................................................................................... P. 75

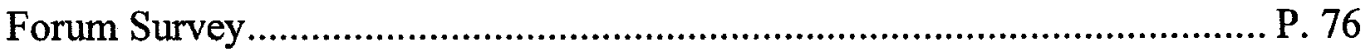

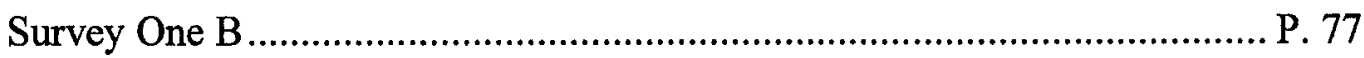

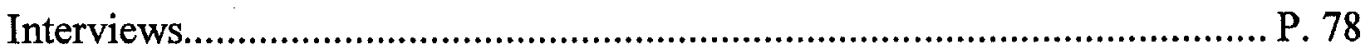

Survey One A and One B Hypothesis Tests.............................................. P. 79

Factor and Cluster Analysis................................................................ P. 125

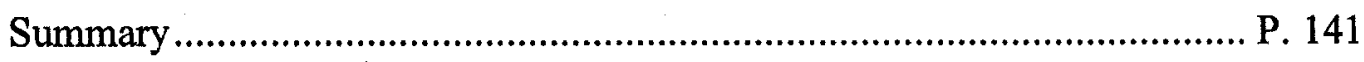

Tangible Outcomes

Forum Survey .................................................................................. P. 144

Survey One-B (Follow-up Survey) ……………...................................... P. 145

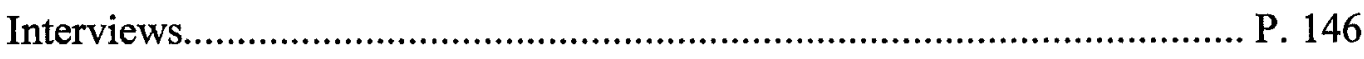

Archival Evidence ............................................................................... 147

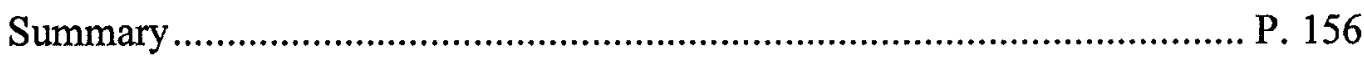

Impacts on the Field .............................................................................. P. 157

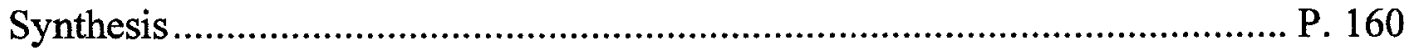

Chapter Five: Case Concordance with MCLA Design Theory ............................. P. 164

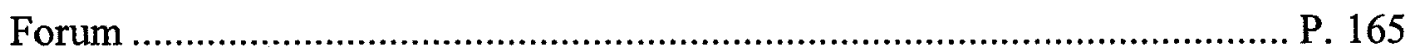

Design Considerations....................................................................... P. 165

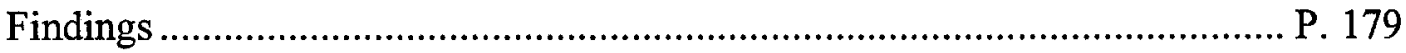

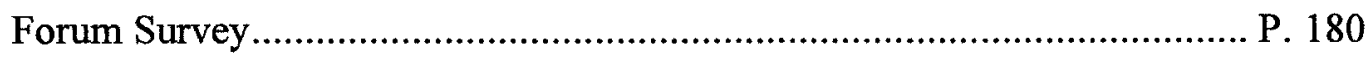


Open Space Action Groups............................................................... P. 185

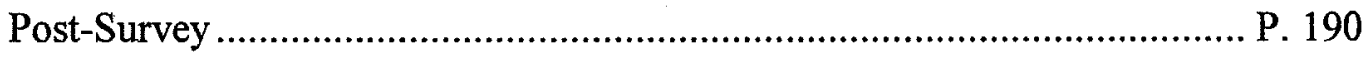

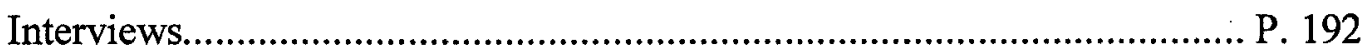

Summary of Forum Findings ................................................................ P. 195

Collaborative Alliance ............................................................................. P. 205

Stakeholder Participation....................................................................... P. 207

Vision and Direction-Setting .......................................................... P. 222

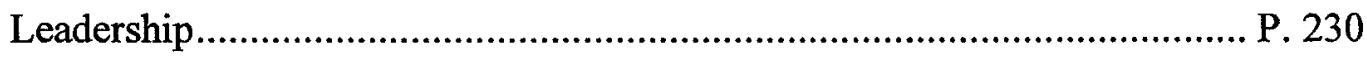

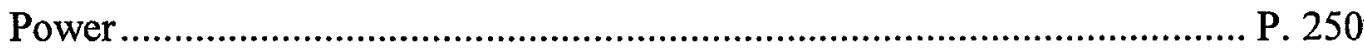

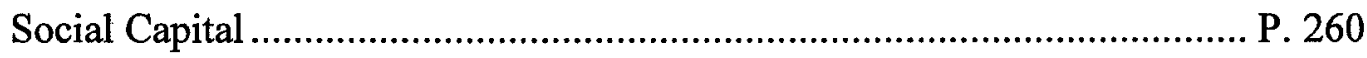

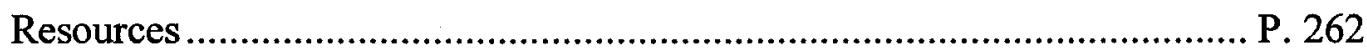

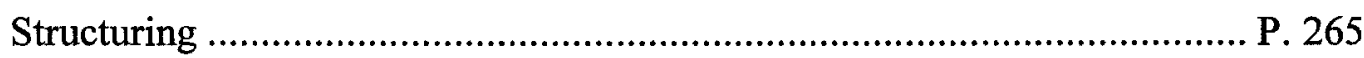

Collaborative Alliance Summary ......................................................... P. 270

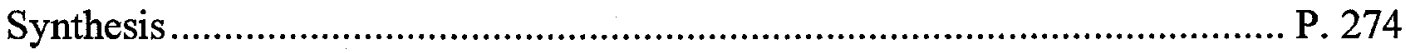

Chapter Six: Conclusions, Implications, Questions.......................................... P. 288

Stakeholder Participation.......................................................................... P. 293

Dominant Discourses ............................................................................ P. 296

Engagement Practices................................................................................... P. 297

Diverse Engagement........................................................................ P. 297

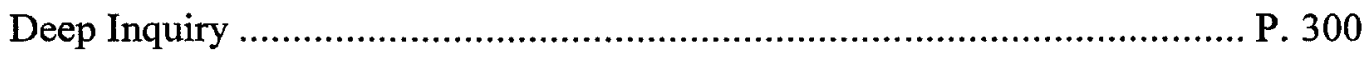

Process Learning ................................................................................. P. 301

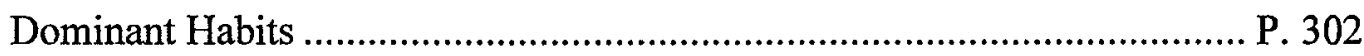


Referent Organization ................................................................. P. 304

Measurement .................................................................................... P. 308

Comparability and Appropriate Use of Processes ..................................... P. 309

Social Change and Sustainability ....................................................... P. 311

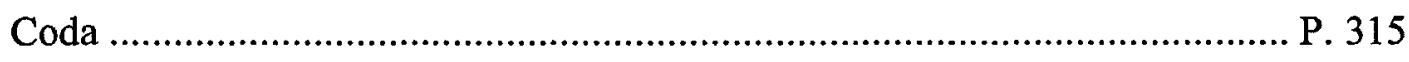

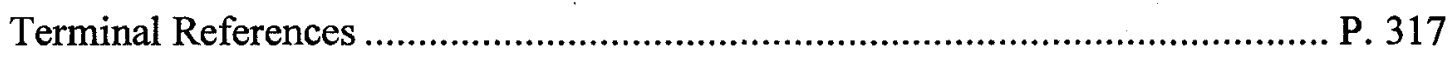

Appendix A: June 2001 Next Steps Form............................................. P. 345

Appendix B: W.K. Kellogg Foundation Food and Society Initiative................. P. 346

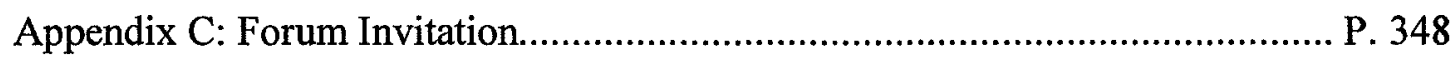

Appendix D: Building a Regional Food Economy Forum Evaluation ................ P. 351

Appendix E: Forum Next Steps Form................................................... P. 353

Appendix F: Follow-up Email Communication ..................................... P. 354

Appendix G: Draft Governance Structure............................................... P. 355

Appendix H: Draft Concept Paper, May 2002 .......................................... P. 356

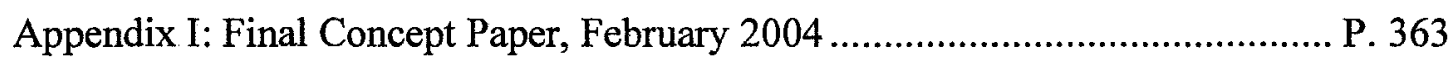

Appendix J: Survey One................................................................. 374

Appendix K: Interview Protocol............................................................. P. 385

Appendix L: School Food Forum Agenda ........................................... P. 388

Appendix M: Regional Food Assessment Forum Evaluation ........................... P. 389

Appendix N: Unrotated and Rotated Component Matrices .......................... P. 391

Appendix O: Forum Orientation Letter..................................................... P. 395

Appendix P: CFM Declaration ............................................................ 397 
Appendix Q: Seed to Supper Draft Curriculum Concept............................... P. 398

Appendix R: Draft Sustainable Food System Indicators .............................. P. 401 


\section{LIST OF TABLES}

Table 1: Literature Review ........................................................................ P. 9

Table 2: Research Populations..................................................................... P. 34

Table 3: Survey One Respondent Age ............................................................. P. 38

Table 4: Survey One Respondent Gender ........................................................... P. 39

Table 5: Survey One Respondent Income............................................................ P. 40

Table 6: Survey One Respondent Education........................................................ P. 41

Table 7: Hypothesis Tests ............................................................................ 4

Table 8: Reliability and Validity in the Literature.................................................. P. 54

Table 9: Hypothesis 1 Findings ………………………................................... P. 82

Table 10a: Hypothesis 2 Findings..................................................................... P. 84

Table 10b: Hypothesis 2 Findings ................................................................... P. 85

Table 11a: Hypothesis 3 Findings................................................................ P. 86

Table 11b: Hypothesis 3 Findings ................................................................. P. 86

Table 12: Hypothesis 4 Findings …………………………................................ P. 90

Table 13a: Hypothesis 5 Findings...................................................................... P. 94

Table 13b: Hypothesis 5 Findings ……………………….............................. P. 95

Table 14a: Hypothesis 6 Findings................................................................... P. 97

Table 14b: Hypothesis 6 Findings ................................................................. 98

Table 15a: Hypothesis 7 Findings................................................................ P. 101

Table 15b: Hypothesis 7 Findings .............................................................. P. 101 
Table 16a: Hypothesis 8 Findings.............................................................. P. 106

Table 16b: Hypothesis 8 Findings ................................................................... P. 107

Table 17: Hypothesis 9 Findings .................................................................. P. 112

Table 18a: Hypothesis 10 Findings................................................................. P. 114

Table 18b: Hypothesis 10 Findings ................................................................. P. 114

Table 19a: Hypothesis 11 Findings................................................................ P. 116

Table 19b: Hypothesis 11 Findings ............................................................ P. 116

Table 20a: Hypothesis 12 Findings............................................................. P. 120

Table 20b: Hypothesis 12 Findings ............................................................. P. 120

Table 21: Pre Eigenvalues And Percent Variance Explained................................ P. 126

Table 22: Post Eigenvalues And Percent Variance Explained .............................. P. 126

Table 23: Component Members Under Three Scenarios for Pre-Survey .............. P. 128

Table 24: Component Members Under Three Scenarios for Post-Survey............. P. 129

Table 25: Pre-Survey Average Scores Loading Scenarios................................... P. 132

Table 26: Post-Survey Average Scores Loading Scenarios .................................. P. 136

Table 27: Forum Evaluation ...................................................................... P. 181 


\section{LIST OF FIGURES}

Figure 1: Case Effects ………………………........................................ P. 161

Figure 2: How and Why MCLA Processes Work …………............................. P. 285 


\section{CHAPTER ONE}

\section{INTRODUCTION AND LITERATURE REVIEW}

Despite increased theoretical and practitioner attention to the subject of multistakeholder processes, questions remain regarding what reasonably to expect from such processes and how best to design them. This chapter introduces the concepts of multi-stakeholder processes, large group interventions, referent organizations, and domain development. Multi-stakeholder collaborative learning and action is defined as a specific type of multi-stakeholder process. Relevant literature is reviewed, and contributions of this research are articulated.

The case description is provided in Chapter Two and the research design and data considerations in Chapter Three. Effects of the multi-stakeholder process are considered in Chapter Four. Concordance between this case and multi-stakeholder collaborative learning and action theory is considered in Chapter Five. Conclusions, questions, and implications for practice and research are provided in Chapter Six.

\section{Multi-stakeholder Processes}

Multi-stakeholder processes (MSPs) are suggested as useful for addressing complex, plural, and uncertain issues (e.g. Bramson \& Buss, 2002; Bunker \& Alban, 1997, 
2005; Calton \& Payne, 2003; Dukes, 1996; Forester, 1999; Healey, 1997; Hemmati, 2002; Innes, 1996, 1999; Pruitt, Waddell, Kaeufer, \& Parrot, 2005; Schusler, Decker, \& Pfeffer, 2003; Trist, 1983; Weisbord, 1992). In these situations - where issues are interrelated, information is distributed, predictions are impossible, and there may be perceived differences of interest to reconcile-MSPs are proposed to have normative, substantive, and instrumental benefits (e.g., people should have voice, better information will result, and agreements will be facilitated) (Pelletier, Kraak, McCullum, Uusitalo, \& Rich, 1999b). MSPs in modern cultures ${ }^{1}$ have roots in a number of fields including Organizational Development, ${ }^{2}$ Policy Analysis, Planning, Conflict Resolution, Education, Community Development, and Natural Resource and Ecosystem Management. MSPs have been applied in such diverse settings as watershed planning, community health promotion, and business strategizing.

Discussion of multi-stakeholder processes is clouded by the fact that they go by many names. Types of MSPs identified in the literature include, for example, multistakeholder dialogue, multi-stakeholder roundtables, cross sector social partnerships, community collaboration, civic collaboration, community problem solving, concertations, dialogic change processes, multi-stakeholder platforms, multistakeholder partnerships, interorganizational collaboration, large group interactions

\footnotetext{
${ }^{1}$ While stakeholders have convened in collaborative learning and action settings in other cultures and times, the focus here is on MSPs in contemporary industrialized societies (which may include stakeholders from non-industrialized, non-Western cultures).

${ }^{2}$ Which include roots in psychology and systems theory (Bunker \& Alban, 1997).
} 
and (sometimes) collaborative planning. MSPs also take many forms. For example, the purpose may be to inform a specific policy or to chart a course for the future of a sector. The timeframe may be a one-time event or an on-going process. The scale may be local, regional, national, or global. The process may be community driven, agency initiated, or statutorily mandated and there may or may not be linkage to official decision-making. The MSP context may or may not include explicit conflict (e.g., a history of animosity or distrust between groups), and may or may not be reactive (e.g., responding to a specific issue or problem rather than starting from a point of developing shared visions and understandings). The participants may all hold positions of authority (e.g., head of an agency or organization), may include grassroots citizens, or entail a mix. The number of participants may range from double digits to over a thousand. Learning assumptions and activities vary (e.g., including presentations by "experts", engaging in critical reflection), as do methods for dealing with disagreement (e.g., create a space for discussion or "parking it").

While there is not a single or dominant definition of multi-stakeholder processes, distinguishing characteristics include convening people with diverse interests or stakes in an issue or domain in a form of "communication, decision-finding (and possibly decision-making) structure" (Hemmati, 2002 p. 19) that improves understanding of the issue, builds and strengthens networks, and aims for equity, accountability, and democratic participation (Hemmati, 2002). 


\section{Multi-stakeholder Processes and Domain Development}

Domains can be thought of as interest, problem, or topic areas. ${ }^{3}$ Domains are suggested to be "underorganized" when regulation mechanisms are not sufficient for task accomplishment and system maintenance (L. Dave Brown, 1980). Domain development is thought to be advanced by networking initiatives, large group interventions, referent organizations, and convening the extended field (Trist, 1983). Large group interventions are a specific type of multi-stakeholder process designed to "get the whole system into the room" in order to build shared understandings and agreements (Bunker \& Alban, 1997). Referent organizations ${ }^{4}$ are suggested to foster domain appreciation (e.g., sense of interconnectedness, emerging trends, and shared future vision) and provide domain regulation (e.g., values, ground rules, relationships) and infrastructure support (e.g., resources, information) (Trist, 1983). This may include networking, convening, and group intervention activities. The structure of a referent organization may be formal or informal, and may change over time. Further, more than one referent organization may exist in a domain at a given time.

\footnotetext{
${ }^{3}$ The term "field" is sometimes also used.

${ }^{4}$ The term referent organization is sometimes used interchangeably or in place of the term bridging organization. Bridging organizations are conceptualized as performing a number of functions including translation, communication, and mediation that can result in trust building, learning or sense-making, conflict resolution, and collaboration (L. David Brown, 1991; Folke, Hahn, Olsson, \& Norberg, 2005). In some instances a distinction can be made; development bridging organizations are primarily concerned with sustainable development and, thus, may seek to cultivate that perspective with stakeholders rather than let a perhaps opposing or incompatible perspective emerge as a guiding vision (L. David Brown, 1993). Though neither the term "referent organization" nor "bridging organization" was used, the Community Food Matters collaborative alliance can be characterized as such.
} 
Domain development is posited to move through three iterative and overlapping phases (Gray, 1985; McCann, 1983): problem-setting ${ }^{5}$ includes identifying stakeholders and coming to appreciate system interdependence and existing conditions; direction-setting includes development of a shared vision and strategy for the domain; structuring includes the development of a regulative framework for the domain.

Multi-stakeholder processes are suggested as facilitative of domain development to the extent that they convene diverse stakeholders, foster shared appreciations (e.g., interconnectedness, emerging trends, and shared future vision), articulate strategy, and/or develop a regulative framework for the domain.

\section{Multi-stakeholder Collaborative Learning and Action}

Given the variety of multi-stakeholder processes, the term Multi-stakeholder Collaborative Learning and Action (MCLA) is offered here to describe MSPs that take a participatory, constructivist, systems perspective in convening diverse stakeholders to share information and articulate and work toward a commonly defined preferred future. Multi-stakeholder Collaborative Learning and Action is defined here as:

\footnotetext{
${ }^{5}$ I prefer the use of a different term such as "issue setting" which is more in line with appreciative and asset-based approaches (e.g., Kretzmann \& McKnight, 1993; Ludema, Cooperrider, \& Barrett, 2001). However, for the purposes of convention, the term problem-setting is used here.
} 
a one-time or on-going endeavor designed explicitly to bring diverse members of a system together for the purposes of increasing individual and system understanding and facilitating individual and collaborative activity that supports movement toward a shared vision or goal.

There are three, interrelated premises for MCLA (and many MSPs):

- we live in a world that is plural - has diverse perspectives and interests; complex - has biocultural systems comprised of innumerable interrelated systems that cannot be fully understood, particularly by one individual or organization; and uncertain - has a complexity and emergence that means it can never be fully predicted or "managed"

- system members' diverse perspectives and interests contribute to our collective understanding of the world and system members have a right to participate in conversations and actions to shape that world

- this plurality, complexity, and uncertainty necessitate fora for building shared understandings of biocultural systems and agreements for defining and working toward a preferred future.

The connection between collaboration, learning, and action is key, for while theoretically all learning is action (knowing is actively constructed even when done subconsciously), and all learning is collaborative (individuals' understandings exist in 
relation to input from others), the interest here is in facilitating collaboration that builds individual and shared understandings and facilitates individual and collective shaping of the world toward a commonly defined preferred future. ${ }^{6}$ A group of teachers who meet to learn about and create a school reform initiative would not count as MCLA because the multi-stakeholder dimension is missing. Nor would a speaker series targeted to diverse school system stakeholders count as MCLA because the collaborative learning and action element is missing. Further, while collaborative learning and action can be exclusionary and maladaptive (e.g., a racist group meeting to "learn about" and plot against another group) - the very point of multi-stakeholder collaborative learning and action is the convening of diverse perspectives to work toward shared understandings and agreements.

\section{Literature Review}

The literature review focused on research that considered effects of multi-stakeholder collaborative learning and action processes and/or concordance between actual interventions and theory pertaining to process design.

\footnotetext{
${ }^{6}$ As per (Daniels \& Walker, 1996), the term "collaborative learning" is not employed here in the sense that it is in antensive education literature referring to peer learning and mentoring.
} 
Seventeen journal articles were identified, with fourteen of the seventeen identified articles published between 2000 and $2005 .^{78}$ The seventeen articles published to date represent twenty-one cases (i.e., some articles address multiple cases). Seven articles (nine cases) pertain to natural resource management (Alvarez, Diemer, \& Stanford, 1999; Daniels \& Walker, 1996; Everett \& Jamal, 2004; Poncelet, 2001a, 2001b;

Schusler, Decker, \& Pfeffer, 2003; Turcotte \& Pasquero, 2001), two articles (four cases) pertain to community and economic development (Oels, 2002; Schafft \& Greenwood, 2003), two articles (two cases) pertain to health care (Clarke, 2005; Polanyi, 2001), and six articles (six cases) pertain to community food security (representing one research project) (McCullum, Pelletier, Barr, \& Wilkins, 2002, 2003; Pelletier, Kraak, McCullum, \& Uusitalo, 2000; Pelletier, Kraak, McCullum, Uusitalo, \& Rich, 1999a, 1999b; Pelletier, McCullum, Kraak, \& Asher, 2003). Search or Future Search events are considered in twelve of the articles (fourteen of the cases), and multi-stakeholder roundtables or partnerships are considered in four of the articles (six of the cases). A summary of this research is provided in Table 1. Salient findings from this research are summarized below.

\footnotetext{
${ }^{7}$ The eleven articles published after the Colloquium and Forum did not influence the research or intervention design, but did significantly influence the analysis.

${ }^{8}$ The Journal of Applied Behavioral Science published a special issue on large group interventions in March $2005(41,1)$. One of the articles in that issue was included in this review (Clarke, 2005). The others deal primarily with descriptions of process methods and, thus, were not included in this review of relevant research.
} 
Table 1: Literature Review

\begin{tabular}{|c|c|c|c|c|c|}
\hline Author & Date & Journal & MSP & Issue & Research Question(s) \\
\hline $\begin{array}{l}\text { Alvarez, } \\
\text { et al. }\end{array}$ & 1999 & $\begin{array}{l}\text { Culture and } \\
\text { Agriculture } \\
21(2)\end{array}$ & $\begin{array}{l}\text { Search } \\
\text { Conference }\end{array}$ & $\begin{array}{l}\text { Natural } \\
\text { Resource } \\
\text { Management: } \\
\text { Community } \\
\text { Forestry }\end{array}$ & $\begin{array}{l}\text { Impact of participatory } \\
\text { planning effort } \\
\text { (Search) on attitudes } \\
\text { related to community } \\
\text { development. }\end{array}$ \\
\hline Clarke & 2005 & $\begin{array}{l}\text { The Journal } \\
\text { of Applied } \\
\text { Behavioral } \\
\text { Science } \\
41(1)\end{array}$ & $\begin{array}{l}\text { Search } \\
\text { Conference }\end{array}$ & $\begin{array}{l}\text { Mental } \\
\text { Health Care }\end{array}$ & $\begin{array}{l}\text { Impact of Search, } \\
\text { particularly on social } \\
\text { relationships. }\end{array}$ \\
\hline $\begin{array}{l}\text { Daniels \& } \\
\text { Walker }\end{array}$ & 1996 & $\begin{array}{l}\text { Environmental } \\
\text { Impact } \\
\text { Assessment } \\
\text { Review } 16\end{array}$ & $\begin{array}{l}\text { Collaborative } \\
\text { Learning }\end{array}$ & $\begin{array}{l}\text { Natural } \\
\text { Resource } \\
\text { Management: } \\
\text { Coastal } \\
\text { Ecosystem } \\
\text { Management }\end{array}$ & $\begin{array}{l}\text { Effectiveness of } \\
\text { Collaborative Learning } \\
\text { model and application to } \\
\text { Ecosystem Based } \\
\text { Management. }\end{array}$ \\
\hline $\begin{array}{l}\text { Everett \& } \\
\text { Jamal }\end{array}$ & 2004 & $\begin{array}{l}\text { Journal of } \\
\text { Management } \\
\text { Inquiry } 13(1) \\
\end{array}$ & $\begin{array}{l}\text { Multi- } \\
\text { stakeholder } \\
\text { Collaborative } \\
\text { Roundtable } \\
\end{array}$ & $\begin{array}{l}\text { Natural } \\
\text { Resource } \\
\text { Management } \\
\end{array}$ & $\begin{array}{l}\text { Role of power in } \\
\text { collaboration, } \\
\text { particularly with respect } \\
\text { to meaning management } \\
\text { and agenda setting. }\end{array}$ \\
\hline $\begin{array}{l}\text { McCullum, } \\
\text { et al. }\end{array}$ & 2002 & $\begin{array}{l}\text { Journal of the } \\
\text { American } \\
\text { Dietetic } \\
\text { Association } \\
102(7)\end{array}$ & $\begin{array}{l}\text { Search } \\
\text { Conference }\end{array}$ & $\begin{array}{l}\text { Community } \\
\text { Food } \\
\text { Security }\end{array}$ & $\begin{array}{l}\text { Meanings of community } \\
\text { food security; degree to } \\
\text { which common ground } \\
\text { could be found; } \\
\text { participatory nature of } \\
\text { event. }\end{array}$ \\
\hline $\begin{array}{l}\text { McCullum, } \\
\text { et al. }\end{array}$ & 2003 & $\begin{array}{l}\text { Journal of } \\
\text { Nutrition } \\
\text { Education } \\
\text { and Behavior } \\
35(4)\end{array}$ & $\begin{array}{l}\text { Search } \\
\text { Conference }\end{array}$ & $\begin{array}{l}\text { Community } \\
\text { Food } \\
\text { Security }\end{array}$ & $\begin{array}{l}\text { How power influences } \\
\text { agenda setting during } \\
\text { Search Conference } \\
\text { process; incorporation of } \\
\text { disenfranchised } \\
\text { stakeholders' most } \\
\text { salient interests into } \\
\text { Search Conference } \\
\text { action agendas. }\end{array}$ \\
\hline Oels & 2002 & $\begin{array}{l}\text { Systems } \\
\text { Research and } \\
\text { Behavioral } \\
\text { Science } 19 \\
\end{array}$ & Future Search & $\begin{array}{l}\text { Community } \\
\text { Development } \\
\text { : Local } \\
\text { Agenda } 21 \\
\text { Planning } \\
\end{array}$ & $\begin{array}{l}\text { Criticisms of FS } \\
\text { including opening, } \\
\text { common ground phase, } \\
\text { and action planning } \\
\text { phase. }\end{array}$ \\
\hline $\begin{array}{l}\text { Pelletier, } \\
\text { et al. }\end{array}$ & 1999 & $\begin{array}{l}\text { Agriculture } \\
\text { and Human } \\
\text { Values } 16\end{array}$ & $\begin{array}{l}\text { Search } \\
\text { Conference }\end{array}$ & $\begin{array}{l}\text { Community } \\
\text { Food } \\
\text { Security }\end{array}$ & $\begin{array}{l}\text { Salience of CFS values } \\
\text { to SC participants; } \\
\text { development of common } \\
\text { ground; satisfaction with } \\
\text { Search Conference. }\end{array}$ \\
\hline
\end{tabular}




\begin{tabular}{|c|c|c|c|c|c|}
\hline $\begin{array}{l}\text { Pelletier, } \\
\text { et al. }\end{array}$ & 1999 & $\begin{array}{l}\text { Policy } \\
\text { Sciences } 32\end{array}$ & $\begin{array}{l}\text { Search } \\
\text { Conference }\end{array}$ & $\begin{array}{l}\text { Community } \\
\text { Food } \\
\text { Security }\end{array}$ & $\begin{array}{l}\text { Effects of democratic } \\
\text { deliberation in a Search } \\
\text { conference to } \\
\text { participants' viewpoints. }\end{array}$ \\
\hline $\begin{array}{l}\text { Pelletier, } \\
\text { et al. }\end{array}$ & 2000 & $\begin{array}{l}\text { Agriculture } \\
\text { and Human } \\
\text { Values } 17\end{array}$ & $\begin{array}{l}\text { Search } \\
\text { Conference }\end{array}$ & $\begin{array}{l}\text { Community } \\
\text { Food } \\
\text { Security }\end{array}$ & $\begin{array}{l}\text { Impact of participation } \\
\text { on viewpoints - stability } \\
\text { of factors and } \\
\text { membership. }\end{array}$ \\
\hline $\begin{array}{l}\text { Pelletier, } \\
\text { et al. }\end{array}$ & 2003 & $\begin{array}{l}\text { The Journal } \\
\text { of Nutrition }\end{array}$ & $\begin{array}{l}\text { Search } \\
\text { Conference }\end{array}$ & $\begin{array}{l}\text { Community } \\
\text { Food } \\
\text { Security }\end{array}$ & $\begin{array}{l}\text { Salience of CFS values; } \\
\text { effectiveness of action } \\
\text { planning: role of power. }\end{array}$ \\
\hline Polanyi & 2001 & $\begin{array}{l}\text { The Journal } \\
\text { of Applied } \\
\text { Behavioral } \\
\text { Science } 37(4)\end{array}$ & Future Search & $\begin{array}{l}\text { Repetitive } \\
\text { Strain } \\
\text { Injuries }\end{array}$ & $\begin{array}{l}\text { Future Search claims } \\
\text { regarding processes } \\
\text { (open, inclusive, } \\
\text { democratic) and outcomes } \\
\text { (mutual understanding } \\
\text { and collective action). } \\
\end{array}$ \\
\hline Poncelet & 2001 & $\begin{array}{l}\text { Policy } \\
\text { Sciences } 34 \\
\end{array}$ & $\begin{array}{l}\text { Multi- } \\
\text { stakeholder } \\
\text { Environmental } \\
\text { Partnership } \\
\end{array}$ & $\begin{array}{l}\text { Natural } \\
\text { Resource } \\
\text { Management }\end{array}$ & $\begin{array}{l}\text { Personal Transformation } \\
\text { from participation in } \\
\text { multi-stakeholder } \\
\text { environmental } \\
\text { partnership: existence, } \\
\text { reasons, implications. }\end{array}$ \\
\hline Poncelet & 2001 & $\begin{array}{l}\text { Environmental } \\
\text { Management } \\
27(1)\end{array}$ & \begin{tabular}{l|} 
Multi- \\
stakeholder \\
Environmental \\
Partnership
\end{tabular} & $\begin{array}{l}\text { Natural } \\
\text { Resource } \\
\text { Management }\end{array}$ & $\begin{array}{l}\text { Evidence of, and } \\
\text { explanations for, conflict } \\
\text { avoidance in multi- } \\
\text { stakeholder partnerships. }\end{array}$ \\
\hline $\begin{array}{l}\text { Schafft \& } \\
\text { Greenwood }\end{array}$ & 2003 & $\begin{array}{l}\text { Journal of the } \\
\text { Community } \\
\text { Development } \\
\text { Society } 34(1)\end{array}$ & $\begin{array}{l}\text { Search } \\
\text { Conference }\end{array}$ & $\begin{array}{l}\text { Community } \\
\text { Development }\end{array}$ & $\begin{array}{l}\text { Better understand } \\
\text { benefits and dilemmas of } \\
\text { participatory approaches } \\
\text { to community } \\
\text { development. }\end{array}$ \\
\hline $\begin{array}{l}\text { Schusler, } \\
\text { et al. }\end{array}$ & 2003 & $\begin{array}{l}\text { Society and } \\
\text { Natural } \\
\text { Resources } 15\end{array}$ & $\begin{array}{l}\text { Search } \\
\text { Conference }\end{array}$ & $\begin{array}{l}\text { Natural } \\
\text { Resource } \\
\text { Management: } \\
\text { Wildlife } \\
\text { Management } \\
\text { Area }\end{array}$ & $\begin{array}{l}\text { Assess evidence for } \\
\text { social learning and } \\
\text { action, process } \\
\text { characteristics fostering } \\
\text { social learning, role of } \\
\text { social learning in } \\
\text { collaborative } \\
\text { management: } \\
\text { particularly id of } \\
\text { common purpose and } \\
\text { transformation of } \\
\text { relationships. } \\
\end{array}$ \\
\hline $\begin{array}{l}\text { Turcotte } \\
\& \\
\text { Pasquero }\end{array}$ & 2001 & $\begin{array}{l}\text { The Journal } \\
\text { of Applied } \\
\text { Behavioral } \\
\text { Science } 37(4)\end{array}$ & $\begin{array}{l}\text { Multi- } \\
\text { stakeholder } \\
\text { Collaborative } \\
\text { Roundtable }\end{array}$ & $\begin{array}{l}\text { Natural } \\
\text { Resource } \\
\text { Management: } \\
\text { Waste } \\
\text { Management }\end{array}$ & $\begin{array}{l}\text { Assess three outcomes: } \\
\text { multi-stakeholder } \\
\text { consensus, learning, and } \\
\text { problem solving. }\end{array}$ \\
\hline
\end{tabular}


Overall, the research provides strong support for the contention that participants in MCLA processes may evidence substantive learning (about issues), relational learning (about other stakeholders), and processual learning (collaborative skills) (Alvarez, Diemer, \& Stanford, 1999; Clarke, 2005; Daniels \& Walker, 1996; McCullum, Pelletier, Barr, \& Wilkins, 2002; Oels, 2002; Polanyi, 2001; Poncelet, 2001b; Schusler, Decker, \& Pfeffer, 2003; Turcotte \& Pasquero, 2001). Where identification of common ground was a specific process goal, and was measured, evidence was also affirmative. Further, parties were able to find areas of common ground - even in conflictual environments and/or the presence of diverse viewpoints (Alvarez, Diemer, \& Stanford, 1999; Clarke, 2005; McCullum, Pelletier, Barr, \& Wilkins, 2002; Oels, 2002; Pelletier, Kraak, McCullum, Uusitalo, \& Rich, 1999a; Pelletier, McCullum, Kraak, \& Asher, 2003; Polanyi, 2001; Poncelet, 2001b; Schusler, Decker, \& Pfeffer, 2003; Turcotte \& Pasquero, 2001). Ambiguity was found to be facilitative of goal setting; that is, diverse groups often can agree more easily on broadly stated preferred goals or outcomes than on means to achieve the goals (Clarke, 2005; Polanyi, 2001; Turcotte \& Pasquero, 2001). Tangible and intangible effects were observed, however intangible and secondary effects were often noted to be the more significant (Clarke, 2005; Polanyi, 2001; Schusler, Decker, \& Pfeffer, 2003; Turcotte \& Pasquero, 2001). Such intangible effects include development of networks, norms, trust, and collaborative capacity. Stakeholder recruitment was identified as a significant challenge in some cases (Everett \& Jamal, 2004; Schafft \& Greenwood, 2003), though 
mostly was not addressed. Further, contrary to claims made by large group intervention proponents, implementation of action agendas was found to be problematic in each research case that examined the issue (Alvarez, Diemer, \& Stanford, 1999; Oels, 2002; Pelletier, Kraak, McCullum, Uusitalo, \& Rich, 1999a; Pelletier, McCullum, Kraak, \& Asher, 2003; Polanyi, 2001; Schafft \& Greenwood, 2003; Schusler, Decker, \& Pfeffer, 2003).

Findings were not consistent with respect to observed changes in viewpoint. ${ }^{9}$ Poncelet (2001b) found that participants in an Environmental Partnership ${ }^{10}$ transformed values and assumptions - and that these transformations appeared to be expansive rather than contractive. That is, understanding of other stakeholders deepened, new relationships were formed, and problem-solving repertoires were expanded. Polanyi (2001) found that participants in a Future Search for the most part did not appear to change personal beliefs. Schusler et al. (2003) found that concerns about the resource issue were revised for participants in a Search Conference, mostly with the types of concerns expanding. Pelletier et al. $(2000 ;, 1999 \mathrm{~b})$ observed viewpoint change for some Search Conference participants and suggest that social or environmental concerns were reduced for some (defined by factor membership and loading); however, details are not provided regarding the ways that individual

\footnotetext{
${ }^{9}$ As per Pelletier et al. (2000 P. 91), the term viewpoint is assumed to "reflect an indeterminate mix of values, beliefs, attitudes, opinions, and factual knowledge."

${ }^{10}$ Comprised of participants from all three of the government, business, and environmental NGO sectors, voluntarily working together to address issues proactively rather than in response to a well defined, existing conflict (Poncelet, 2001b P. 276).
} 
viewpoints changed (e.g., if a person retained a strong concern about hunger but altered their view regarding hunger relief strategies did this appear as a lessoning of social justice salience?). It is not at all clear whether the differences in findings regarding viewpoint change are attributable to variation in intervention methods (i.e., Future Search, Environmental Partnership, Search Conference), definition of viewpoint change, other contextual issues (e.g., different participant characteristics, issues addressed), or research questions and methods.

The notion of power was problematized in five of the research projects. With respect to participation, (Schafft \& Greenwood, 2003) found that cultural, social, and political capital greatly influenced participation, even though concerted efforts to attend to power differentials were made. Similarly, Everett and Jamal (2004) and Poncelet (2001a) found that some individuals and organizations exercise power by opting not to participate in the multi-stakeholder process. Clarke (2005) identified political effects due to changes in network centrality (i.e., increased influence/power).

With respect to agenda setting, Everett and Jamal (2004) found that surface power (defined as decision authority) did not have a substantive influence on the process but that deep power (defined as management of meaning) did, with some voices (sectors) privileged more than others. Voices with the most cultural, social, and political capital had the power to shape agendas and a dominant scientific, technical, instrumental rationality prevailed (science, business, and reform/modernist environmentalist voices 
over social, health, education, culture, and First Nation voices). Poncelet (2001a) found an ecological modernism discourse privileged, defining such a discourse as one that takes an instrumental, economic, rational science collective action approach to ecological issues. ${ }^{11}$ McCullum et al. (2002; , 2003) and Pelletier et al. (2003) found that "powerful" participants more successfully had their salient interests included on the action agendas than disenfranchised participants. Also, as noted above, they found that some viewpoints changed to align with more powerful stakeholders (i.e., those with greater cultural capital and linguistic legitimacy). The authors also identified four mechanisms that influenced agenda setting: managing or controlling knowledge (avoiding sensitive issues), problem framing (choice of terms, premature decisions, narrowly defining interests), trust (selecting participants based upon perceived legitimacy or credibility), and consent (selecting participants based upon anticipated reaction) McCullum (2003).

Conflict minimization was identified by Clarke (2005), Everett and Jamal (2004), McCullum (2002), Poncelet (2001a), and Schluser (2003). Conflict minimization behaviors included disengagement and withholding, reconciliation by seeking common ground, polite behavior, and diffusion of conflict (Poncelet, 2001a). Poncelet (2001a) suggests that a politics of interest perspective is insufficient for explaining the observed pattern of conflict avoidance and posits that cultural models of partnership

\footnotetext{
${ }^{11}$ The term is not uncontested. CF (Andersen \& Massa, 2000; Fisher \& Freudenburg, 2001; Langhelle, 2000).
} 
(as inherently non-confrontational) and a privileged discourse of ecological modernization suggestive of partnership contribute significantly to understanding the phenomenon.

While research to date has contributed significantly to our understanding of multistakeholder processes, important questions remain regarding their design and effects. Further, most research has focused narrowly on one or a few topics pertaining to MSPs and MCLA: There is a need for research that brings a multidisciplinary, holistic perspective to bear on these interventions. Finally, although multi-stakeholder processes have been identified as useful for domain development (Gray, 1985; Trist, 1983), there is little research linking the two.

\section{Contributions of this Research}

This research considers a multi-stakeholder collaborative learning and action case related to sustainable regional food systems. Food systems are an appropriate domain to consider as they evidence the properties of complexity, plurality, and uncertainty suggested to benefit from MCLA. A web of actors interacts through the food system to affect human and ecological health. For example, agricultural lands provide flood control and wildlife habitat to urban ecosystems, while agriculture practices affect water quality, water quantity, fisheries, biodiversity, and farm worker health. Socio- 
ecological health is also impacted through the processing, distribution, and disposal of food products. Community health is impacted through such vectors as access to nutritious and affordable food, diet related disease, food quality and safety, and the supply and safety of food industry workers. The economy is influenced directly through food purchases, as well as indirectly through food system expenditures on inputs, packaging, transportation, and disposal.

This research contributes to the literature in three ways. First, it responds to the call for additional research on MSPs (e.g., Bramson \& Buss, 2002; Bryson \& Anderson, 2000; Calton \& Payne, 2003; Hemmati, 2002) - including more longitudinal research to capture MSP evolution and effects on the field (Clarke, 2005; Everett \& Jamal, 2004; Poncelet, 2001b; Schusler, Decker, \& Pfeffer, 2003; Selsky \& Parker, 2005). Second, this research examines the assertion that MSPs contribute to domain development and does so by analyzing both a large group intervention and a collaborative alliance functioning as a referent organization. Third, considering a diverse range of factors, the research provides a more holistic, contextual understanding of MCLA (Caffarella \& Merriam, 1999; El Ansari, Phillips, \& Hammick, 2001; Imperial, 2005; Innes \& Booher, 2002; Lasker \& Weiss, 2003; Pasquero, 1991; Perkins et al.). 


\section{CHAPTER TWO}

\section{CASE DESCRIPTION}

The following case description provides information essential for understanding the research findings and interpreting them in the context of MCLA theory. The case is a multi-stakeholder collaborative learning and action process (MCLA) that took place in the metropolitan region of Portland, Oregon. The period of analysis is April 2002 to July 2006. The researcher was involved as a participant observer.

\section{Prologue to the Case}

In the mid-1990s I was part of a multi-organizational, collaborative initiative to promote regional food system sustainability in southeast Pennsylvania. An important component of the initiative was our team's convening of a Future Search with approximately 80 key leaders in the region. A Future Search is a large-group intervention technology designed to assist diverse system stakeholders in defining shared visions and action plans (Bunker \& Alban, 1997; Weisbord, 1992). Our team found that participants in the Future Search were profoundly affected, with many talking about the event for years afterward. More specifically, participants were struck by the fact that 1) they had never experienced farmers, planners, educators, 
policy makers, bankers, nutritionists, and other food system stakeholders all in the same room before, 2) the diverse group had more in common than they thought, including an eleven-point shared vision for the future of the region's food and farm system, and 3) their vision would not be achieved unless they worked together to make it happen.

The event made a significant impression on me as well. Though I did not yet have a name for it, I became intrigued by the potential of Multi-stakeholder Collaborative Learning and Action processes to support diverse stakeholders in defining shared understandings and agreements facilitative of more sustainable communities. In time, I decided to further explore the connections between learning, culture, sustainability and community via a doctoral degree program at Portland State University and committed to "service scholarship" that would benefit the community while contributing to practitioner and academic understanding. My interests and commitment were enabled when I received a mini-grant from Portland State University's School of Urban Studies and Planning to explore possibilities for collaboration on regional food system issues.

In June 2001 I convened a group of approximately twenty diverse food system stakeholders to consider the merits of developing a collaborative, systemic regional food system initiative. As events were unfolding, it became clear to me that an excellent opportunity for service scholarship in the area of multi-stakeholder 
collaborative learning and action was materializing. I conceptualized a research design, secured human subjects review approval for survey and interview protocols, and received approval from my dissertation committee to move forward with the research (Colloquium date - April 1, 2002).

\section{Birth of Community Food Matters}

The stakeholders convened in June 2001 included representation from food production, food access, and community and economic development. The group unanimously agreed that the idea of addressing regional food system issues systemically and collaboratively had merit and that the time was right to do so. Participants at the meeting made individual commitments to either assist in developing and guiding the regional food system initiative, review proposal drafts, write letters of support, and/or participate later in projects (Appendix A). The researcher served as convener and manager of the work group formed to develop the collaborative regional food system initiative.

The region was initially defined as "eaters" in the six-county Portland metropolitan region $^{1}$ and producers ${ }^{2}$ within a half-day's drive from the six-county Portland metropolitan area. That definition was later revised to include eaters in the six-county

${ }^{1}$ Clackamas, Columbia, Multnomah, Washington, and Yamhill Counties in Oregon and Clark County in Washington.

${ }^{2}$ Sometimes the term growers or providers was substituted for producers. 
Portland metropolitan region and producers in Oregon and Washington ${ }^{3}$ that serve them. While there was interest in a bioregional definition, initial boundaries were selected based on pragmatics such as availability of geopolitical data, feasibility of scope, and membership served by participating organizations. The regional definition was made with the acknowledgement that it was a "working definition" - a useful heuristic subject to change with time.

The group agreed that while many good efforts were underway "the whole was less than the sum of its parts" and food system sustainability remained compromised. An integrated portfolio of projects providing a holistic and collaborative approach was suggested as likely to positively impact regional food system sustainability. The W.K. Kellogg Foundation ${ }^{4}$ had recently unveiled its Food and Society Initiative (Appendix B) and the group decided to use development of a concept paper to the Kellogg Foundation as a platform for clarifying its strategy. Screening criteria to identify priority projects were developed and members were invited to propose projects that fit with the objectives, leveraged existing resources, included a broad range of stakeholder groups, and had likelihood of success. Participants were reminded that the concept paper may or may not be accepted and that, even if so, additional resources would be required. Thus, the concept paper was supposed to serve as an organizing aide rather than a driver of the collaboration.

\footnotetext{
${ }^{3}$ For some time the focus was Southwest Washington rather than all of Washington.

${ }^{4}$ Referred to in this document as the Kellogg Foundation.
} 
In October 2001, during the project brainstorming and vetting process, Ecotrust ${ }^{5}$ broached the possibility of collaborating on a food systems related event as part of its Conservation Economy Workshop Series. The offer included significant resources in the way of catering, publicity, speaker fees, venue acquisition, and logistical support and carried with it a spirit of collaboration and inclusiveness of the wider food community. The group, which by now had named itself Community Food Matters, agreed that partnering on a regional food system event would be appropriate and beneficial: doing so would provide a venue for learning and action among diverse regional food system stakeholders, a public launch of Community Food Matters, an opportunity to "ground truth" the value and direction of the emerging endeavor including draft project ideas, and a mechanism to identify and invite other appropriate stakeholders to participate in the process.

\section{The Large Group Intervention (Forum)}

A Forum design team was established and the Forum goals were defined as:

- Develop shared vision/values for the region's food system

- Build bridges and partnerships (networks) between individuals and groups working on various facets of regional sustainable community food systems

\footnotetext{
${ }^{5}$ Ecotrust is a Portland-based $501 \mathrm{c} 3$ that fosters a conservation economy in the "Salmon Nation" bioregion extending from Alaska to California.
} 
- Increase individual and collective understanding of sustainability dimensions of regional community food systems

- Define action strategies in support of sustainable regional food systems

- Be a model for other community food system efforts

- Launch the Community Food Matters regional food system initiative.

For communication purposes these goals were condensed as:

- Increase understanding of regional food system issues

- Define action strategies in support of a sustainable regional food system

- Launch the collaborative, regional food system initiative - Community Food Matters.

The planning team intended to have approximately 100 participants at the Forum, with a maximum of 120 . This decision represented a balance between being open to as many people as possible while maintaining a group size that would be manageable for small group work, report outs and relationship building. Approximately 250 invitations (Appendix C) were extended, and 142 people replied. Attendance was approximately 100 (with minor fluctuations in attendance during the event). Efforts were made to invite key stakeholders of influence who should be "at the table" during the process of defining and implementing projects in support of regional community food systems. Potential screening criteria included leadership role in a specific stakeholder organization or community, diversity (rural-urban, ethnic, age, food 
system sector represented), and ability to consider diverse perspectives and work with others.

The event, titled Growing the Regional Food Economy: A Forum for Promoting Good Jobs, Food Access, Environmental Stewardship, and Farm Viability, was held April $11^{\text {th }}$ and $12,{ }^{\text {th }} 2002$ at the recently opened Jean Vollum Natural Capital Center - a LEED certified green building. Benefits of the space (e.g., lighting, air quality, ADA accessibility, non-toxic materials, price, proximity to transit) were deemed to outweigh potential shortcomings (i.e., lack of space for breakouts, few restrooms, and limited parking options). Meals, snacks, and beverages were provided free of charge to participants and consisted of sustainably and locally produced sources. Packaging was minimized and composting and recycling were available.

The Forum design and agenda are discussed in Chapter Five. Forum attendees were asked to complete a Forum Evaluation (Appendix D) and Next Steps Form (Appendix E) developed to ascertain level of interest in participating in CFM, opinion of the value of a regional food systems center, and other feedback.

A follow up communication was sent to participants on May $10^{\text {th }}$ (Appendix F). The communication included a review of the aims of CFM, announcement of the formation of the Launch Team (below), the draft concept paper, the Open Space report outs, and details about how to stay involved. 


\section{Identifying a Home, Structure, and Purpose for the Collaborative Alliance}

Following the Regional Food Economy Forum held April 11th and 12th ${ }^{\text {th }}, 2002$, a "Launch Team" was formed and charged with defining the mission, structure, and home for Community Food Matters (CFM). The team represented expertise in food production, food access, community and economic development, and food system related education. Organizations represented included the Agri-business Council of Oregon, Ecotrust, Food Alliance, ${ }^{6}$ Friends of Zenger Farm, ${ }^{7}$ Growing Gardens, ${ }^{8}$ City of Portland Community Gardens Program, City of Portland/Multnomah County Food Policy Council, Oregon Department of Agriculture, Oregon Economic and Community Development Department, Oregon Food Bank, Oregon State University Extension Service, Oregon State University/Oregon Department of Agriculture Food Innovation Center, Mercy Corps Northwest, ${ }^{9}$ and Washington State University Small Farms Program.

\footnotetext{
${ }^{6}$ A third-party certification organization for sustainable food production.

${ }^{7}$ A sustainable agriculture education center whose target audiences include low income and minority populations.

${ }^{8}$ An organization working with low income populations to install and maintain home food growing gardens.

${ }^{9}$ An economic development organization working with low income, minority, and immigrant populations.
} 
By October 2002, the CFM mission was defined as "improving economic, environmental, and human health in rural and urban communities through the development of sustainable community food systems." The methods for achieving the mission were defined as 1) convening real and virtual spaces for networking and learning about food system issues, 2) collecting and sharing information about regional food system issues, 3) helping to catalyze responses to identified gaps and opportunities.

Establishment of 501c3 status was considered but the team determined it would be prudent to have a "host" for CFM for at least two to three years in order to have an infrastructure to support the organization's growth. The primary candidates for "housing" Community Food Matters were Ecotrust, Oregon State University via the Food Innovation Center, and an OSU-Ecotrust partnership. A draft governance structure was created in July 2002, but was never operationalized (Appendix G). During this time OSU staff encountered budget and staffing restrictions and significant additional cuts were threatened; OSU hosting of CFM seemed to be a less viable option. In November 2002 the team accepted Ecotrust's offer to host the "launch" of CFM for a period of a few years, with the option of spinning off or staying on as appropriate. This decision was based on Ecotrust's (bio)regional vs. state focus, seemingly more stable operating climate, and history of launching new projects in the region. 
The Launch Team became an Advisory Board after the decision was made to move CFM to Ecotrust. It was suggested that being on the Board would entail meeting four times per year, reviewing and providing input on workplan and strategy, providing ideas and resources for events, providing content to the listserv, assisting with fundraising, and having the home organization's name listed on letterhead. In reality, roles and responsibilities for the host institution and board were not clarified or formalized, nor were communication frameworks and decision-making protocols. Time to discuss Board roles and responsibility was on the agenda for the May 2003 meeting, though the discussion was eliminated due to time constraints when the group decided to have a half-day retreat rather than a full-day retreat.

In April 2004, Ecotrust determined that it needed to exit its role of host to CFM. Ecotrust continued to provide bookkeeping and phone support until a suitable alternative was found. One key staff member left the Advisory Board, although another staff member who had been involved since the first gathering in June 2001 remained on the Advisory Board. Ecotrust's exit from its hosting role raised the question of whether CFM should find a new host, become its own non-profit organization, or cease to exist. The matter was taken up at the May 2004 Advisory Board retreat. The value of CFM was reiterated to be networking and information sharing. A model of self-organization was offered by a professor and consultant in non-profit management who facilitated the meeting. The group agreed that it might be 
willing to try such a model, at least in the short term. However, significant issues · were raised and the model was not implemented.

In 2005, CFM "moved" to Portland State University's (PSU) School of Community Health and Nohad A. Toulan School of Urban Studies and Planning under the leadership of Leslie McBride, Advisory Board member and faculty in PSU's School of Community Health, and her colleague Barry Messer, faculty in PSU's School of Urban Studies and Planning. The move stemmed from a grant secured by Drs. McBride and Messer in March 2004 to build faculty capacity to teach about community food systems and place students in community-based service learning settings that would build civic skills related to these issues. ${ }^{10}$ The decision to move was based on funding expected through 2006 and compatibility between CFM's convening, networking, and information sharing objectives ${ }^{11}$ and the University's mandates. During the grant period the idea of morphing CFM into a Center for Food and Community Studies was explored; the idea attracted favorable feedback, however no action was taken.

\footnotetext{
${ }^{10}$ Funding came from PSU's Center for Academic Excellence via the National Corporation for Service Learning as part of the Oregon Civic Solutions project.

${ }^{11}$ The objective of catalyzing projects to respond to identified gaps and opportunities was seen as a subset of the convening role -- facilitating stakeholders in identifying issues and responses rather than advocating for or implementing projects.
} 


\section{The W.K. Kellogg Foundation Concept Paper}

A significant portion of the Launch Team/Advisory Board effort went to development of a concept paper for the Kellogg Foundation's Food and Society initiative. An integrated portfolio of programs and projects was developed aiming for a collaborative, systemic strategy that would promote a sustainable regional food system and also meet the Foundation's articulated interests. By May 2002 a concept paper (Appendix $\mathrm{H}$ ) was developed that defined the program portfolio to include food economy entrepreneurship, expanded and enhanced markets, community food literacy and policy work, and community food system assessment. Projects were defined within each of the program areas.

Although a draft concept paper had been prepared by May 2002, and the group anticipated a June 2002 submission, it took until February 2004 for the final concept paper to be submitted (Appendix I). There were three primary reasons for this delay. First, over time the Launch Team/Advisory Board became less confident that CFM should undertake projects. Board members saw CFM's primary value as a convener of spaces for networking and learning and a hub for meaningful information about the state of the region's food system. Working on a concept paper that included projects when support for projects was waning was obviously problematic. Related to this, many project teams were having difficulty defining their leader, tasks, timelines, and budgets, thus impacting the ability to develop a coherent and complete proposal. 
Finally, having CFM within the fold of another organization caused additional delays (e.g., needing to secure permission to apply to the funder, coordinating with development staff and other application timeframes). The concept paper to the W.K. Kellogg Foundation was submitted in February 2004; word that a full proposal was not invited was received in March of the same year.

\section{Staffing}

CFM "staff" included both volunteers (e.g., AmeriCorps members and interested residents), and paid positions. The director ${ }^{12}$ (the researcher) received remuneration for some services and also contributed significant amounts of pro bono work (approximately 5 to 20 hours per week over the life of the project). Additional paid staff included 10 to 15 hours per week of graduate assistant time to provide support with administrative details, research, and project implementation between March 2004 and June 2006.

In addition to the volunteer Board and project team members, CFM hosted approximately twenty-two other volunteers. ${ }^{13}$ Some were recruited through an AmeriCorps program (seven for 2002-2003 and two for 2003-2004), some were

\footnotetext{
12 Also referred to as the manager or coordinator.

${ }^{13}$ Volunteers who served in a "one-shot" capacity such as assisting with registration at an event or working a shift at the New Seasons Barbeque fundraisers are not included in this figure.
} 
recruited through PSU's College of Urban and Public Affairs, and others were individuals with food system interests who simply heard about the initiative and wanted to "get involved." There were more requests (solicited and unsolicited) to volunteer than could be accommodated. Volunteers were provided with an orientation to the history, mission, and objectives of the organization. Assignments were made attempting to match interests and needs; work plans with tasks and timelines were negotiated.

A number of volunteers made significant contributions, though an equal or greater number did not complete their assignments. Reasons varied from personal issues (e.g., personal health or family problem), prioritization of school or job commitments, and/or dissatisfaction with assignment or placement (e.g., not feeling able to execute tasks or having conflict with sub-team members). Examples of productive volunteer arrangements include a professional photographer interested in food and justice issues who visited local growers and markets to create images for use by CFM; an AmeriCorps volunteer who coordinated a research effort on institutional purchasing; a recent transplant to Portland with significant community food systems experience who assisted with administrative details, curriculum identification, and creation of a database of food related films; and a volunteer who assisted with logo and website development, fund raising, and administrative assistance before transitioning to a position on the Advisory Board (s/he was hired as Executive Director of an 
organization and replaced the exiting Executive Director who had been serving on the Board).

\section{Activities}

CFM (via members, staff, and volunteers) engaged in a number of activities and played a number of roles during the 2002 to 2006 time period. As detailed more fully in Chapter Four, CFM generated reports, hosted events, replied to information requests, wrote letters of support, brokered relationships, created resources lists, spoke to classroom and community groups, facilitated stakeholder meetings, mentored students and young professionals, assisted with curriculum development, and shared ideas and information about sustainable food systems and collaboration.

\section{Epilogue}

Funding for the CFM-PSU effort expired in June 2006, bringing the existence of CFM to an end. At the time of this writing there is no longer a coordinator or director for the initiative. Discussions have occurred with PSU faculty and the Portland/Multnomah Food Policy Council (FPC) staff regarding continuation of listerv maintenance, website maintenance, and data collection and dissemination, however no decisions have been made. 


\section{CHAPTER THREE}

\section{RESEARCH DESIGN AND DATA CONSIDERATIONS}

\section{Research Standpoint}

Interpretivist, critical, and realist paradigms inform the ontological, epistemological and methodological perspectives of this research. The research draws on the case study tradition for its ability to elucidate phenomena in context (Stake, 1995; Yin, $1993,1994)$, and the action research tradition for its commitment to democratic social change (Greenwood \& Levin, 1998). Multiple methods, both quantitative and qualitative, are utilized in a complementary fashion (Bentz \& Shapiro, 1998; El Ansari, Phillips, \& Hammick, 2001; Frey, 1994; Schafft \& Greenwood, 2003; Schutt, 1999; Yin, 1994). This "compatabilist" (Howe, 1988), mixed-methods (Greene, 2005), integrative (Moran-Ellis et al., 2006) approach is taken in the interest of generating more rich, valid, reliable, and complete understandings. 


\section{Research Questions}

As discussed in Chapter Two, the case is a multi-stakeholder collaborative learning and action process (MCLA) that took place in the metropolitan region of Portland, Oregon. The period of analysis is April 2002 to June 2006. There are two, related, research questions:

- What were the effects of a specific multi-stakeholder collaborative learning and action process pertaining to sustainable regional food systems?

- What is the concordance between this specific process and MCLA design theory?

This purpose of this case study is to improve understanding about what reasonably to expect from MCLA processes and how best to design them, as well as the relationships between multi-stakeholder processes and domain development (specifically large group interventions and collaborative alliances).

The case (unit of analysis) is the MCLA process; individual participants comprise embedded units of analysis and the large group intervention (Forum) and collaborative alliance management team (Launch Team/Advisory Board) comprise 
embedded units of analysis (Yin, 1994). The researcher was involved as a participant observer.

\section{Research Methods}

Data from five sources were triangulated to inform understanding of the case. The

five research components include:

- Baseline and follow-up survey

- Forum evaluation survey

- Interviews with Launch Team/Advisory Board members

- Documents and archival data

- Participant-observer notes

Each research component is described in more detail below. Table 2 summarizes the target populations for the surveys and interviews.

Table 2: Research Populations

Survey One

Baseline (One A) - Forum participants and "interested" non-participants.

Follow-up (One B) - All respondents who completed Survey One A.

Survey Two

All Forum participants.

Interviews

Launch Team/Advisory Team members participating between October 2001 and June 2003. 
Baseline and Follow-up Survey

Survey One A and One B, the pre- and post-survey, were designed to yield information regarding beliefs, values and behaviors with respect to community food system issues. The survey included 40 Likert statements about food system beliefs ( 7 point scale), 16 Likert statements about food purchase decisions (4 point scale), 15 Likert statements about food acquisition locations ( 6 point scale), and open questions (e.g., "In what ways do you think that attending this Forum will impact you professionally?"). The survey design was informed by related research on this topic (Dunlap, Van Liere, Mertig, \& Jones, 2000; Kempton, Boster, \& Hartley, 1995; Kloppenburg, Lezberg, DeMaster, Stevenson, \& Hendrickson, 2000; Pelletier, Kraak, McCullum, \& Uusitalo, 2000; Pelletier, Kraak, McCullum, Uusitalo, \& Rich, 1999) and was pre-tested in a graduate studies research seminar. The survey instrument, which received Human Subjects approval from Portland State University, can be found in Appendix J.

Survey One A, the baseline or pre-survey, was administered to persons who registered for the Forum and persons who responded that they wanted to attend but were unable 
to do so (e.g., a scheduling conflict). ${ }^{1}$ The population of invitees who wanted to attend the Forum but were unable to serves as the control or comparison group. This quasi-experimental design provides an opportunity to explore potential differences between Forum participants and non-participants. Respondents who completed the baseline survey were re-surveyed approximately nine months after the Forum. Survey One B, the follow-up or post survey, repeated the baseline survey questions and, on the version sent to Forum attendees (i.e., not to the control group), included additional questions specifically referencing the Forum. An addressed, stamped envelope was provided for all surveys.

Forty-nine Forum participants and sixteen control respondents successfully completed both Survey One A and B ( $49 \%$ of Forum participants and $92 \%$ of participant presurveys, and $46 \%$ of the control group and $76 \%$ of control group pre-surveys). These are moderate response rates, within acceptable ranges, though with potential nonrespondent bias (Assessment, 2006; Babbie, 1983; Baruch, 1999; Mundy, 2002).

Twelve of the forty-nine Forum participants who completed both the pre- and postsurvey were also Launch Team/Advisory Board ${ }^{2}$ members, yielding three comparison

\footnotetext{
'The response card offered three choices: "Yes. I will attend the Forum April $11^{\text {th }}$ and $12^{\text {th }}$," "I am interested in attending but cannot make it. Please inform me of future news and events" and "I am not interested in participating in the Forum or other regional food economy events."

${ }^{2}$ As described in Chapter Two, a core management team formed to guide the CFM collaboration. This group was originally called the Launch Team, and then transitioned to being an Advisory Board/Advisory Council.
} 
groups: Forum participants who were members of the work group $n=12$, Forum participants that were not members of the work group $n=37$, and the control group $\mathrm{n}=16$.

Demographic information for respondents to Survey One A and B is provided in Tables 3 to 6 . The majority of respondents for all three groups were between 20 and 50 years old $(70 \%, 91 \%$, and $81 \%$ for Forum Not Work Group, Forum Work Group, and Control, respectively). The Forum respondent populations were slightly more diverse in age range (membership in each category between 20-30 and 61-70 versus the control group having no members in the $20-30$ or $61-70$ range). There were more female Forum respondents than male respondents (68\% vs. $32 \%$ for Forum Not Work Group and $73 \%$ v $27 \%$ for Forum Work Group) while the control group was evenly split with respect to gender (50\% and 50\%). The three groups had similar percentages of respondents reporting annual household income under $\$ 70,000(56 \%, 44 \%$, and $43 \%$ respectively for Forum Not Work Group, Forum Work Group, and Control). The Forum Work Group respondents, however, reported more household income greater than $\$ 90,000(56 \%, 19 \%$, and $29 \%$ for Forum Work Group, Forum Not Work Group, and Control, respectively). Few respondents reported household income less than $\$ 30,000(8 \%, 11 \%$, and 0, respectively, for Forum Not Work Group, Forum Work Group, and Control). All three groups reported high levels of formal education. A four year degree or greater was reported by $89 \%, 100 \%$, and $86 \%$ of respondents for Forum Not Work Group, Forum Work Group, and Control, respectively. The 
Forum Work Group and Control Group had the highest levels of formal education, with $58 \%$ and $64 \%$, respectively, reporting a Master's degree or higher compared to $38 \%$ for the Forum Not Work Group.

Table 3: Survey One Respondent Age

\begin{tabular}{|c|c|c|c|c|}
\hline $\begin{array}{l}\text { Participation CFM } \\
\text { Work Group }\end{array}$ & Frequency & Percent & $\begin{array}{l}\text { Valid } \\
\text { Percent }\end{array}$ & $\begin{array}{l}\text { Cumulative } \\
\text { Percent }\end{array}$ \\
\hline \multicolumn{5}{|l|}{ Forum, Not Work Group } \\
\hline 20 to 30 & 6 & 16.2 & 16.2 & 16.2 \\
\hline 31 to 40 & 5 & 13.5 & 13.5 & 29.7 \\
\hline 41 to 50 & 15 & 40.5 & 40.5 & 70.3 \\
\hline 51 to 60 & 8 & 21.6 & 21.6 & 91.9 \\
\hline 61 to 70 & 3 & 8.1 & 8.1 & 100.0 \\
\hline Total & 37 & 100 & 100 & \\
\hline \multicolumn{5}{|l|}{ Forum, Work Group } \\
\hline 20 to 30 & 3 & 25.0 & 27.3 & 27.3 \\
\hline 31 to 40 & 3 & 25.0 & 27.3 & 54.5 \\
\hline 41 to 50 & 4 & 33.3 & 36.4 & 90.9 \\
\hline 51 to 60 & 1 & 8.3 & 9.1 & 100.0 \\
\hline 61 to 70 & 0 & 0 & 0 & 0 \\
\hline Total & 11 & 91.7 & 100.0 & \\
\hline Missing & 1 & 8.3 & & \\
\hline Total & 12 & 100.0 & & \\
\hline \multicolumn{5}{|l|}{ Control } \\
\hline 20 to 30 & 0 & 0 & $\mathbf{0}$ & 0 \\
\hline 31 to 40 & 4 & 25.0 & 25.0 & 25.0 \\
\hline 41 to 50 & 9 & 56.3 & 56.3 & 81.3 \\
\hline 51 to 60 & 3 & 18.8 & 18.8 & 100.0 \\
\hline 61 to 70 & 0 & & & 0 \\
\hline Total & 16 & 100.0 & 100.0 & \\
\hline
\end{tabular}


Table 4: Survey One Respondent Gender

\begin{tabular}{|c|c|c|c|c|}
\hline $\begin{array}{l}\text { Participation CFM } \\
\text { Work Group }\end{array}$ & Frequency & Percent & $\begin{array}{l}\text { Valid } \\
\text { Percent }\end{array}$ & $\begin{array}{l}\text { Cumulative } \\
\text { Percent }\end{array}$ \\
\hline \multicolumn{5}{|l|}{ Forum, Not Work Group } \\
\hline Male & 12 & $\overline{32.4}$ & 32.4 & 32.4 \\
\hline Female & 25 & 67.6 & 67.6 & 100.0 \\
\hline Total & 37 & 100.0 & 100.0 & \\
\hline \multicolumn{5}{|l|}{ Forum, Work Group } \\
\hline Male & 3 & 25.0 & 27.3 & 27.3 \\
\hline Female & 8 & 66.7 & 72.7 & 100.0 \\
\hline Total & 11 & 91.7 & 100.0 & \\
\hline Missing & 1 & 8.3 & & \\
\hline Total & 12 & 100.0 & & \\
\hline \multicolumn{5}{|l|}{ Control } \\
\hline Male & 8 & 50.0 & 50.0 & 50.0 \\
\hline Female & 8 & 50.0 & 50.0 & 50.0 \\
\hline Total & 16 & 100.0 & 100.0 & \\
\hline
\end{tabular}


Table 5: Survey One Respondent Income

\begin{tabular}{|c|c|c|c|c|}
\hline $\begin{array}{l}\text { Participation CFM } \\
\text { Work Group }\end{array}$ & Frequency & Percent & $\begin{array}{l}\text { Valid } \\
\text { Percent }\end{array}$ & $\begin{array}{l}\text { Cumulative } \\
\text { Percent }\end{array}$ \\
\hline \multicolumn{5}{|l|}{ Forum, Not Work Group } \\
\hline $10 \mathrm{~K}$ to $30 \mathrm{~K}$ & 3 & 8.1 & 8.3 & 8.3 \\
\hline $30,001 \mathrm{~K}$ to $50 \mathrm{~K}$ & 10 & 27.0 & 27.8 & 36.1 \\
\hline $50,001 \mathrm{~K}$ to $70 \mathrm{~K}$ & 7 & 18.9 & 19.4 & 55.6 \\
\hline $70,001 \mathrm{~K}$ to $90 \mathrm{~K}$ & 9 & 24.3 & 25.0 & 80.6 \\
\hline $90,001 \mathrm{~K}$ to $110 \mathrm{~K}$ & 3 & 8.1 & 8.3 & 88.9 \\
\hline $110,000<$ & 4 & 10.8 & 11.1 & 100.0 \\
\hline Total & 36 & 97.3 & 100.0 & \\
\hline Missing & 1 & 2.7 & & \\
\hline Total & 37 & 100.0 & & \\
\hline \multicolumn{5}{|l|}{ Forum, Work Group } \\
\hline $10 \mathrm{~K}$ to $30 \mathrm{~K}$ & 1 & 8.3 & 11.1 & 11.1 \\
\hline $30,001 \mathrm{~K}$ to $50 \mathrm{~K}$ & 2 & 16.7 & 22.2 & 33.3 \\
\hline $50,001 \mathrm{~K}$ to $70 \mathrm{~K}$ & 1 & 8.3 & 11.1 & 44.4 \\
\hline $70,001 \mathrm{~K}$ to $90 \mathrm{~K}$ & 0 & 0 & 0 & 44.4 \\
\hline $90,001 \mathrm{~K}$ to $110 \mathrm{~K}$ & 2 & 16.7 & 22.2 & 66.7 \\
\hline $110,000<$ & 3 & 25.0 & 33.3 & 100.0 \\
\hline Total & 9 & 75.0 & 100.0 & \\
\hline Missing & 3 & 25.0 & & \\
\hline Total & 12 & 100.0 & & \\
\hline \multicolumn{5}{|l|}{ Control } \\
\hline $10 \mathrm{~K}$ to $30 \mathrm{~K}$ & 0 & 0 & 0 & 0 \\
\hline $30,001 \mathrm{~K}$ to $50 \mathrm{~K}$ & 3 & 18.8 & 21.4 & 21.4 \\
\hline $50,001 \mathrm{~K}$ to $70 \mathrm{~K}$ & 3 & 18.8 & 21.4 & 42.9 \\
\hline $70,001 \mathrm{~K}$ to $90 \mathrm{~K}$ & 4 & 25.0 & 28.6 & 71.4 \\
\hline $90,001 \mathrm{~K}$ to $110 \mathrm{~K}$ & 1 & 6.3 & 7.1 & 78.6 \\
\hline $110,000<$ & 3 & 18.8 & 21.4 & 100.0 \\
\hline Total & 14 & 87.5 & 100.0 & \\
\hline Missing & 2 & 12.5 & & \\
\hline Total & 16 & 100.0 & & \\
\hline
\end{tabular}


Table 6: Survey One Respondent Education

\begin{tabular}{|c|c|c|c|c|}
\hline $\begin{array}{l}\text { Participation CFM } \\
\text { Work Group }\end{array}$ & Frequency & Percent & $\begin{array}{l}\text { Valid } \\
\text { Percent }\end{array}$ & $\begin{array}{l}\text { Cumulative } \\
\text { Percent }\end{array}$ \\
\hline \multicolumn{5}{|l|}{$\begin{array}{l}\text { Forum, Not Work } \\
\text { Group }\end{array}$} \\
\hline HS Grad/GED & 1 & 2.7 & 2.7 & 2.7 \\
\hline Some College & 2 & 5.4 & 5.4 & 8.1 \\
\hline 2 YR College Degree & 1 & 2.7 & 2.7 & 10.8 \\
\hline 4 YR College Degree & 15 & 40.5 & 40.5 & 51.4 \\
\hline Some Grad Work & 4 & 10.8 & 10.8 & 62.2 \\
\hline Master's Degree & 9 & 24.3 & 24.3 & 86.5 \\
\hline Some Doctoral Work & 1 & 2.7 & 2.7 & 89.2 \\
\hline Ph.D. & 4 & 10.8 & 10.8 & 100.0 \\
\hline Total & 37 & 100.0 & 100.0 & \\
\hline \multicolumn{5}{|l|}{ Forum, Work Group } \\
\hline HS Grad/GED & $\overline{0}$ & 0 & 0 & 0 \\
\hline Some College & 0 & 0 & 0 & 0 \\
\hline 2 YR College Degree & 0 & 0 & 0 & 0 \\
\hline 4 YR College Degree & 4 & 33.3 & 33.3 & 33.3 \\
\hline Some Grad Work & 1 & 8.3 & 8.3 & 41.7 \\
\hline Master's Degree & 4 & 33.3 & 33.3 & 75.0 \\
\hline Some Doctoral Work & 0 & 0 & 0 & 75.0 \\
\hline Ph.D. & 3 & 25.0 & 25.0 & 100.0 \\
\hline Total & 12 & 100.0 & 100.0 & \\
\hline \multicolumn{5}{|l|}{ Control } \\
\hline HS Grad/GED & 0 & $\mathbf{0}$ & 0 & 0 \\
\hline Some College & 2 & 12.5 & 14.3 & 14.3 \\
\hline 2 YR College Degree & 0 & 0 & 0 & 14.3 \\
\hline 4 YR College Degree & 2 & 6.3 & 7.1 & 21.4 \\
\hline Some Grad Work & 2 & 12.5 & 14.3 & 35.7 \\
\hline Master's Degree & 5 & 31.3 & 35.7 & 71.4 \\
\hline Some Doctoral Work & 1 & 6.3 & 7.1 & 78.6 \\
\hline Ph.D. & 3 & 18.8 & 21.4 & 100.0 \\
\hline Total & 14 & 87.5 & 100.0 & \\
\hline Missing & 2 & 12.5 & & \\
\hline Total & 16 & 100.0 & & \\
\hline
\end{tabular}

Qualitative survey data was coded and frequencies tabulated. As described below, hypothesis tests were conducted in order to explore change in beliefs and behaviors. Responding to Pelletier et al.'s (2000; Pelletier, Kraak, McCullum, Uusitalo, \& Rich, 1999) research on viewpoint change among Search Conference participants, Q Factor analysis and Cluster Analysis were conducted and are also described below. 
Hypothesis Tests

Twelve hypotheses were tested to determine whether Forum participants evidenced a change in beliefs or behaviors. The first four hypotheses consider whether there were any extant differences between populations at time one (prior to the Forum), the next four hypotheses consider whether there were any differences between populations at time two (nine months after the Forum), and the third set of hypotheses consider whether there were any differences between pre-survey and post-survey responses. Potential differences by amount of time at the Forum, work group participation, and gender are explored. The hypotheses are listed in Table 7.

As discussed below, normality of distribution, homogeneity of variance, and type of data (e.g., interval or ordinal) were considered in determining which statistical tests to run. 
Table 7: Hypotheses Tests

\begin{tabular}{|c|c|}
\hline & Pre-Survey \\
\hline $\mathrm{H1}$ & No difference between forum and non-forum groups in the pre-survey. \\
\hline $\mathrm{H} 2$ & No difference by forum participation (all, most, little, control) in the pre-survey. \\
\hline H3 & $\begin{array}{l}\text { No difference by work group participation (work group, non-work group, control) in the } \\
\text { pre-survey. }\end{array}$ \\
\hline \multirow{2}{*}{$\mathrm{H} 4$} & No difference in responses to the pre-survey by gender. \\
\hline & Post-Survey \\
\hline $\mathrm{H} 5$ & No difference between forum and non-forum groups in the post-survey. \\
\hline H6 & No difference by forum participation (all, most, little, control) in the post-survey. \\
\hline H7 & $\begin{array}{l}\text { No difference by work group participation (work group, non-work group, control) in the } \\
\text { post-survey. }\end{array}$ \\
\hline \multirow[t]{2}{*}{$\mathrm{H} 8$} & No difference in responses to the post-survey by gender. \\
\hline & Change Scores \\
\hline H9 & No difference between pre-survey and post-survey responses. \\
\hline $\mathrm{H} 10$ & $\begin{array}{l}\text { No difference between pre-survey and post-survey responses by forum participation (all, } \\
\text { most, little, control). }\end{array}$ \\
\hline H11 & $\begin{array}{l}\text { No difference between pre-survey and post-survey responses by work group } \\
\text { participation (work group, non-work group, control) }\end{array}$ \\
\hline $\mathrm{H} 12$ & No difference between pre-survey and post-survey responses by gender. \\
\hline
\end{tabular}

Normality of distribution is an assumption for most parametric tests. Given the small sample size of this case study, a normal sampling distribution cannot be presumed. Kolmogorov-Smirnov and Shapiro-Wilk tests were run to confirm assumptions of normality. Kolmogorov-Smirnov test results for each group were significant at or below .05 for most variables and Shapiro-Wilk test results were significant at .01 for most variables; therefore, the normality assumption is not reasonable. While ANOVA and other parametric tests can be robust even when population distributions are skewed, the $F$ test can be sensitive to population skewness if the sample sizes are seriously unbalanced - a condition of this data. 
Homogeneity of variance is another assumption of most parametric tests. Marked violation of the homogeneity of variance assumption can lead to over- or underestimation of significance levels; the more unequal the sample sizes the smaller the differences in variances that is acceptable (G. David Garson, n.d.; Sheskin, 1997). The Levene's test of homogeneity of variance was calculated, with homogeneity identified for most, but not all, variables.

Non-parametric tests were utilized given the non-normal distributions and use of Likert data. ${ }^{3}$ Equivalent parametric tests were run as a comparison given the lesser power associated with non-parametric tests. Potential differences between two groups (H1, 4, 5, 8, 9, 12) were explored with the Independent Samples T test, the MannWhitney test and Phi/Cramer's V test. The Independent Samples T test considers differences in means (distribution of differences between sample means), while the non-parametric alternative Mann-Whitney considers differences in medians. The Phi and Cramer's V tests were run for Question 41 as the four-point Likert scaled used for this question may be more appropriately considered as a nominal rather than ordinal measure. Potential differences between three groups $(\mathrm{H} 2,3,6,7,10,11)$ were explored with the One-way Analysis of Variance test, Kruskal-Wallis test, Phi and Cramer's V tests, and Welch and Brown-Forsythe tests. The Kruskal-Wallis test is a non-parametric alternative to the One-way Analysis of Variance. Where the Levene's

\footnotetext{
${ }^{3}$ Likert scales of seven or more points are often interpreted as interval rather than ordinal data, however, some debate continues regarding this convention.
} 
test for equality of means is less than .05 , equal variance is not assumed and the Welch and Brown-Forsythe tests were computed (Becker, 1999; G. David Garson, n.d.; G. David Garson, n.d.). Again, the Phi and Cramer's V tests were calculated for Question 41 as a nominal rather than ordinal measure may be more appropriate for the four-point Likert scale used for this question. The Games-Howell post-hoc test was used as it is suggested when group size or variance are unequal (G. David Garson, n.d.; Sheskin, 1997; Toothaker, 1993).

Power ( 1 minus beta) is the probability of correctly rejecting the null hypothesis when it is false (being able to identify a difference when there is one). Power depends on alpha (significance level), sample size, and effect size (how much a difference the treatments make) (Keppel, 1991; Stevens, 1996). When effect size is expected to be small (as is the case here) a greater sample size is needed (Keppel, 1991). Also, when differences in means and sample sizes are small (as is the case here) there is less likelihood of finding significance (G. David Garson, n.d.). Thus, power in this study is reduced by the decision to adhere to the alpha convention of .05 , anticipated small effect size, and sample size - which, given the quasi-experimental, naturalistic design, could not be modified. 


\section{$Q$ Factor Analysis}

Q Factor Analysis is a technique for identifying groups of individuals who similarly answer a set of questions or statements. ${ }^{4}$ A matrix is created that places statements in rows and people in columns (an inverse R Factor analysis). Correlations in each cell refer to the degree of similarity with which two people respond to the set of statements: resulting factors ${ }^{5}$ refer to groups of people that responded to the statements similarly (Pelletier 1999, values). The primary steps in analysis include determining the number of components, assigning cases to components, calculating average scores for components, interpreting the components, and, in this case, examining stability of viewpoint and component membership over time.

Q Factor Analysis was conducted using Principal Component Analysis (PCA) in SPSS with varimax rotations. Standard methods for determining the number of factors include Kaiser rule of eigenvalues ${ }^{6}$ greater than or equal to one (especially with twenty to fifty variables), the Cattel scree plot test, and the percent of variance

\footnotetext{
${ }^{4}$ In many instances individuals perform "Q sorts" where statements are sorted according to level of agree/disagree on a point scale akin to the Likert scale used for questions one through forty on the pre/post-survey in this case. For information on Q methodology see Brown (1980, 1993).

5 The terms component and factor are often used interchangeably, though technically components is the accurate term here as principal components analysis is being used rather than principal factor analysis/principal axis factoring.

${ }^{6}$ The eigenvalue for a given component or factor measures the variance in all the variables which is accounted for by that component/factor. A factor with a low eigenvalue is contributing little to the explanation of variability in how individuals respond (the amount of variation in the total sample accounted for by each factor; not the percent of variance explained but a measure of amount compared to other eigenvalues) (G. David Garson, n.d.).
} 
criterion (first $\mathrm{n}$ factors explaining $50 \%$ to $90 \%$ of variance) (Brown, 1980, 1993; G. David Garson, n.d.; StatSoft, 2002).

In Q Factor analysis, factor (component) loadings express the extent to which each case is correlated with a factor. There are no firm rules for determining the significance of factor loadings: .30 or .40 is suggested as a minimum and .50 is suggested as a reasonably strong standard (Brown, 1980, 1993; G. David Garson, n.d.). Issues to consider include sample size (larger sample means smaller loading to be considered significant); number of variables (the larger the number being analyzed the smaller the load to be considered significant); number of factors (the larger the number of factors the larger the size of the loading to be considered significant). Results at .50 and .60 loading thresholds were compared in order to determine how sensitive results were to various loading thresholds. 


\section{Cluster Analysis}

Cluster analysis, another technique for determining the presence of groups, was also performed. Where Q factor groups are based on correlations between respondent scores, cluster groups are based on differences between respondent scores. The two methods can lead to different results as correlations (factor) group people by similarity of response pattern (profile) and cluster groups people by similarity of score or distance between cases.

There are many cluster methods and different methods may yield different results for the same data (Aldenderfer \& Blashfield, 1984). ${ }^{7}$ Given the exploratory nature of the question, a variety of analysis techniques were used and results compared. Nine cluster analysis techniques were performed on Forum participant responses to items one to forty on the pre- and post-survey (a total of eighteen analyses). ${ }^{8}$ The nine cluster tests include: average between Euclidean, average between squared Euclidean distance, average between Euclidean standardized $\mathrm{z}$ scores, average within, single/nearest, complete/furthest, centroid, median, and Ward.

\footnotetext{
${ }^{7}$ For example, linking with the closest individual, closest average individual, closest far individual, or by minimizing within-cluster variance.

${ }^{8}$ The cluster analyses are available from the author.
} 


\section{Forum Survey}

Forum participants were asked to complete a Forum evaluation at the conclusion of the event (Appendix D). This survey was designed to assess the fit between participant assessment of specific Forum elements and theories informing Forum design. As per the Forum design guidelines described in Chapter Five, this included opportunities to be heard, respect for diversity, relevance, learner engagement, comfort of learning environment, climate of trust and respect, opportunities for reflection, pace and timeframe, feeling at ease, and clarity about follow up. Forum survey data also informs questions about impacts (e.g., made contacts, increased understanding, clarified beliefs or values, developed shared vision). Time was allotted at the Forum for completing the survey, with participants invited to stay as long as they needed to complete the survey. Analysis of Forum survey data included simple descriptive statistics, as well as coding of qualitative survey data.

Seventy-one of the 100 Forum attendees completed the Forum evaluation survey (Survey Two). It is likely that a significant portion of non-respondents includes participants who needed to leave early. $71 \%$ is a reasonable response rate, though the potential for non-respondent bias exists. Demographic information was not collected. 
Interviews

Semi-structured interviews were conducted with individuals who served on the collaborative alliance management team. Sixteen interviews were conducted. Fourteen of these individuals attended the full Forum, one attended briefly before leaving for a family emergency, and one was unable to attend. The interviews provide an opportunity to more richly explore impact, meaning, satisfaction, and fit with theory than is possible with the surveys and documents. The interviews were semi-structured, designed in part based on results of the surveys as well as the literature.

Other participants in the process were not interviewed for two reasons. First, survey results indicated that this group and other Forum participants were similarly impacted, reducing the need for follow-up to explore differences between the groups. Second, focusing on members of the management team afforded an opportunity to more deeply understand the MCLA process from the perspective of those involved in its formation and management; perspectives of individuals participating more peripherally on project teams or attending events are interesting and important but are beyond the scope of this research.

The interview protocol can be found in Appendix $\mathrm{K}$. Interviews were conducted in May 2003. Interviews lasted approximately 60 to 90 minutes each. Interviews were 
conducted by the researcher. Participants were reminded that there are no right or wrong answers and that, in the interest of learning as much as possible about what worked and did not in this case, they should feel comfortable offering a full critique including of the researcher. The option of having a more "neutral" party conduct the interviews was considered, however it was determined that having someone familiar enough with the case to identify appropriate probes outweighed potential benefits of hiring an interviewer who had no relationship to the interviewees. To aide interviewee's comfort in being as forthcoming as possible interviewees were given a blank sheet of paper and an addressed, stamped envelope so that they could anonymously submit additional comments. None of the respondents chose to submit anonymous comments. Interviewee ages ranged from the mid-twenties to late fifties. As noted in Chapter Two, interviewees were professionals representing various aspects of food production, food access, and community development and education related to food systems.

Interviews were transcribed, categories were created, and pattern regularities identified (Creswell, 1998; Ely, Anzul, Friedman, Garner, \& McCormack-Steinmetz, 1991). Meaning was derived from both the repetition of phenomena and the single instance (Stake, 1995) (i.e., instances of general agreement and exception were considered). 
Documents and Archival Data

Forum proceedings, meeting minutes, email and listserv records, reports, proposals, announcements, and other such documents were drawn upon to inform analysis of effects and concordance with theory. Over 7,000 documents were generated between June 2001 and June 2006. Analysis focused on material that would inform questions regarding effects (e.g., tangible outputs such as reports) and concordance with theory (e.g., email conversation about an area of conflict).

Participant Observer Notes

Impressions were recorded by the researcher during the course of the process. The notes were consulted in order to aid in the interpretation and confirmation of data.

Synthesis

Areas of convergence and divergence among the research findings were considered (i.e., where the data points toward the same conclusion and where results conflict) and interpretation was informed by extant theory. Triangulating evidence, the research provides a rich and rigorous understanding of the phenomenon. 


\section{Research Quality}

Terms and procedures to address the quality of research vary across methodologies (quantitative and qualitative) and paradigms (positivist, interpretive/constructivist, critical, and realist) (Cresswell, 1998; Ely, 1991; Erlandson, 1993; Lather, 1986; LeCompte and Goetz, 1982; Schutt, 1999; Yin, 1994 clean this). Ultimately, researchers are aiming to ensure that their work is true (credible, internally valid), applicable (transferable, externally valid), consistent (reliable, dependable), and confirmable. Lincoln and Guba (1985) suggest "trustworthiness" as a measure of validity and reliability, with trustworthiness defined as credibility, transferability, dependability, and confirmability (p. 300). They specifically reject the imposition of positivist standards of quality and verification onto non-positivist forms of research, but do identify rough "parallels" between their standards and conventional (positivist) standards. LeCompte and Goetz (1982) and Yin (1984) suggest ways to adapt standards developed for quantitative research to qualitative research. Table 8 summarizes the terms used in these three publications. The following paragraphs speak to how quality concerns are addressed in the proposed research. 
Table 8: Reliability and Validity in the Literature

\begin{tabular}{|l|l|l|l|}
\hline Traditional & Lincoln \& Guba & Yin & LeCompte \& Goetz \\
\hline Internal validity & Credibility & Internal validity & Internal validity \\
\hline External validity & Transferability & External validity & External validity \\
\hline Reliability & Dependability & Reliability & External reliability \\
\hline Objectivity & Confirmability & & \\
\hline & & $\begin{array}{l}\text { Construct } \\
\text { validity }\end{array}$ & \\
\hline & & & Internal reliability \\
\hline
\end{tabular}

Internal validity or credibility (we observed what we think we have observed, our description or interpretation is correct) in this case was addressed through prolonged engagement in the field, persistent observation (critical reflection informed by theory), triangulation of data, provision of contextual information, and member checks (Erlandson, Harris, Skipper, \& Allen, 1993; Guba \& Lincoln, 1994; LeCompte, 1982; Lincoln \& Guba, 1985; Yin, 1994). Each of these is included in the proposed research. Lather (1986) notes that member checks may be limited by the presence of false consciousness, however, this is attended to via the triangulation of data (their check is but one of many checks). Further, sharing the data serves the goal of reciprocity and promoting reflection and learning among the participants (researched). Sharing and discussing results fosters another quality standard - that of catalytic validity or the degree to which the research process stimulates understanding and action (Lather, 1986).

Threats to internal validity associated with quasi-experimental designs (Schutt, 1999) were addressed by checking demographic information to explore differences between 
groups, and making comparisons using data from non-participants who wanted to attend the Forum rather than non-participants who did not want to attend. Maturation, a threat to validity in some quasi-experimental research, was not an issue for this research as group change over time was expected in this context and is part of the study itself. Further, "contamination" may also be part of the story as theory suggests extension of learning benefits into the community. Finally, history effects (something occurs during the experiment other than the treatment that influences the outcome, such as a major event or a newspaper article) were expected to impact both groups equally.

External validity or transferability in this research does not refer to generalizability to a larger population but to applicability to theory and across contexts that share similar (or dissimilar) characteristics (Erlandson, Harris, Skipper, \& Allen, 1993; Yin, 1994). LeCompte and Goetz (1982) replace "generalizability" with "comparability" (delineating the characteristics of the group or constructs clearly enough to serve as a basis for comparison with other like and unlike groups) and "translatability" (delineating methods so that comparisons can be confidently made) (p. 34). Transferability is supported with examples and descriptions, and by linking results to theory (Riege, 2003; Yin, 1994).

External reliability or dependability refers to consistency (procedures are used consistently and carefully), while internal reliability or confirmability refers to 
whether other researchers would arrive at similar conclusions with the same data. Purposive and theoretical sampling, confidentiality, and an audit trail support dependability and confirmability.

Evidence in the proposed research is triangulated in a number of ways: using multiple informants, having the same informant respond to different questions that address the same topic from somewhat different angles, collecting information at different times, and utilizing multiple methods.

A potential limit to the study is the low power associated with the number of respondents in this naturalistic setting, as discussed above. Further, as with any survey achieving less than a $100 \%$ response rate, there are potential non-respondent biases. Another potential limit to the study is associated with the researcher's participant-observer status. However, as all researchers bring biases to their research, what is important is not to pretend that bias can be eliminated, but to be as cognizant and reflective as possible about those biases, to recognize the value of having an insider's perspective, and, in this case, to triangulate methods in order to improve reliability and validity.

The aim of this research is not to be predictive or prescriptive. As Innes \& Booher (1999) note, each process "is uniquely defined by the participants and context; the processes and the stakeholders evolve continuously and unpredictably; and they 
interact with and change their environments while they are at work" (p. 416). At the same time, important contributions can be made to our understanding of effective designs for such multi-stakeholder processes and likely impacts to participants and communities. Such a contribution is made with this research. 


\section{CHAPTER FOUR}

\section{CASE EFFECTS}

The first research question considers the effects of a particular multi-stakeholder collaborative learning and action intervention relating to sustainable community food systems. MSP theory suggests a range of direct and indirect, tangible and intangible effects. ${ }^{1}$ Direct (primary or first order) effects are specifically attributable to the collaborative activity, while indirect (secondary or second order effects) occur outside the boundaries of the collaboration (e.g., a workshop participant shares information that changes someone else's behavior or a spin-off project is developed between two people who met via the collaboration). Tangible effects include things such as plans, policies, proposals, or programs, while intangible effects include things such as social, intellectual, and political capital, or learning.

Results from the five research methods were compared in order to identify significant themes and areas of convergence and divergence. The research methods are described in Chapter Three. Six main themes were identified: substantive learning, relational learning, inspiration, viewpoint change, tangible effects, and impacts on the field. The findings for each of the six categories is presented below, with results for each

\footnotetext{
${ }^{1}$ Proximal effects is another term used - sometimes used interchangeably with primary, direct, first order effects and sometimes referring to effects that occur close in time to the process. Distal effects then refer to secondary, indirect, second order effects or effects that occur later in time.
} 
relevant research method presented sequentially within each category. In the interest of narrative cohesion, interpretation of results is provided in a synthesis and discussion at the end of each category section.

\section{Substantive Learning}

This section reports findings regarding substantive learning effects identified from the Forum survey (Survey Two), follow-up survey (Survey One B), and interview data.

\section{Forum Survey}

On the Forum survey, respondents were asked to rate the following statement:

At the Forum I increased my understanding about the health of this region's food system.

$\begin{array}{ccccc}1 & 2 & 3 & 4 & 5 \\ \text { Strongly } & \text { Disagree } & \text { Not } & \text { Agree } & \text { Strongly } \\ \text { Disagree } & & \text { Sure } & & \text { Agree }\end{array}$

The mean response was 4.25; standardized score $81.25 .^{2}$

\footnotetext{
${ }^{2}$ Standardized mean scores from different scales are calculated as $S=((\mathrm{O}-\mathrm{L}) /(\mathrm{H}-\mathrm{L})) * 10$ where $\mathrm{S}$ is the standardized score, $\mathrm{O}$ is the original rating score on one of the scales, $\mathrm{L}$ is the lowest possible
} 
On the post -survey respondents were asked to rate their agreement with the following, corresponding, statement:

At the Building a Regional Food Economy Forum I increased my understanding about the health of this region's food system.

$\begin{array}{ccccccc}1 & 2 & 3 & 4 & 5 & 6 & 7 \\ \text { Strongly } & \text { Disagree } & \text { Mildly } & \text { Not } & \text { Mildly } & \text { Agree } & \text { Strongly } \\ \text { Disagree } & & \text { Agree } & \text { Sure } & \text { Disagree } & & \text { Disagree }\end{array}$

The mean response was 6.05; standardized score 84.17. Kruskal-Wallis and ANOVA tests controlling for amount of Forum attendance found no significant difference between groups.

Comparatively, the standardized ratings were 81 at the time of the Forum and 84 at the time of the follow-up survey (nine months later). Results indicate that self-rating of increased understanding was strong and stable over time. This was true, even though respondents' mean score for the statement "Prior to this Forum I had a high level of knowledge about regional food system issues" was 3.59 on a five-point scale; the 
standardized score is 64.75 . Respondents also agreed with the statement "The Forum provided a good start to building a shared vision for the region's food system," with the mean score being 4.25 on a five-point scale.

Also at the time of the Forum, participants were asked to respond to the following open-ended question: "In what ways do you think that attending this Forum will impact you professionally?" There were sixty-seven responses to this question (94\% of surveys, and approximately $67 \%$ of Forum attendees). Thirteen respondents (19\%) identified substantive learning effects. For example:

- I will have a broader perspective about the varied yet connected elements of our complex system - I understand the whole system better.

- It will increase my understanding of the issues and stakeholders in this arena. Participants were also asked to respond to the following open-ended question: "In what ways do you think that attending this Forum will impact you personally?" Sixtyfour participants responded to this question ( $90 \%$ of survey respondents and approximately $64 \%$ of Forum attendees). Eight respondents (13\%) identified substantive learning effects. Given the high score on the survey question regarding increased understanding, it is possible that these low figures can be attributed to the fact that participants had already answered the Likert scale question about increased understanding and may have felt little need to repeat the information. 
Survey One-B (Follow-up Survey)

In the follow-up survey (nine months after the Forum), participants were asked to respond to the following open-ended question: "In what ways do you think that attending the April Food Economy Forum impacted you professionally?" Forty respondents replied (62\% percent of surveys and approximately $40 \%$ of Forum participants). Possible explanations for the lower response rate to this question on the post-survey may be that the open-ended questions take more time to complete and were at the end of the survey (survey fatigue), and/or that the respondent felt they had already answered the question on the Forum survey. Twenty respondents (50\%) identified substantive learning effects. For example:

- Helped me understand the number of facets of the regional food system, who's impacted and who is working on it.

- It broadened my knowledge of all the elements of a healthy food system.

- Before, I was unaware of the region's activities.

- Refined the questions/issues surrounding regional food security.

Participants were also asked: "In what ways do you think that attending this Forum will impact you personally?" Thirty-six respondents replied to this question (55\% of surveys and approximately $36 \%$ of Forum participants). Again, possible explanations for the lower response rate to this question on the post-survey may be that the open- 
ended questions take more time to complete and were at the end of the survey (survey fatigue), and/or that the respondent felt they had already answered the question on the Forum survey. Eleven respondents (31\%) identified substantive learning effects. For example:

- It helped deepen the discussion concerning sustainable food systems by raising issues/aspects that I had not strongly considered before attending.

- Made me more aware of local conditions and impact of government.

- It made me realize exactly how many hungry people there are in Oregon.

Interviews

Substantive learning effects identified in the interviews complements the surveys, providing more rich descriptions of the learning that occurred. Examples of substantive learning identified in the interviews include the following:

So for me it's just been this incredible learning experience! Every time I go to a CFM meeting I feel like I double my knowledge. Just in things like, what, for example, farmers deal with or what retailers deal with in the food system; what are the obstacles, what are some of the issues that arise when you're trying to do the right thing- in terms of providing local food. Even what the universities are doing in this realm. I had no idea. Extension services- I had no idea, I knew nothing about Extension services. All of this is this whole wide world that has opened up and it's interesting. Every time I go I feel I learn a lot. I'm excited when it's over.

(Enumerates examples then says)... I think all of those things, that a guy like me in the business side of this don't- am really not in touch with that 
much. That's a nice addition to my frame of reference. Those were all good things. It provides a little more well-rounded view of the whole system.

Yeah, yeah. Now I understand the food system better. Not that I was oblivious to the fact that the small farms are disappearing, but I didn't understand all of their issues...Yeah, deeper understanding of the different components of the food system. And just adding to it, like packaging and waste. ...And, well, I've had more opportunities to learn about sustainability through $\mathrm{X}$ who set me up with people to learn more. I've gained poster making and brochure making experience. I don't know when I would have learned that.

Having the Food Bank there...talking about the state really helped me look at the whole state in a different way. Being there with folks from Ecotrust- where I believe that sustainability and the whole Natural Step approach is important - having a group there that is doing that work has definitely helped me in my thinking about how that kind of thing can happen.

When different members of the group actually give tours or there is a special focus on one of the particular members...Just opportunities to hear from the people who run those facilities or run those organizations and understand what the nuts and bolts of their daily job. It just gives you a whole new world of perspective... I think that just creates huge shifts for the people who are able to be part of those things.

Summary

Consistent with other research, substantive learning is evidenced in this MCLA processes (e.g., Alvarez, Diemer, \& Stanford, 1999; Clarke, 2005; Daniels \& Walker, 1996; Oels, 2002; Poncelet, 2001; Schusler, Decker, \& Pfeffer, 2003; Turcotte \& Pasquero, 2001). Further, the respondents' perception that substantive learning 
occurred was strong and stable over time - even with a relatively high level of prior knowledge about the subject. Of particular note is the degree to which respondent comments regarding substantive learning effects reflect a systems quality. That is, many respondents identified an increased understanding or appreciation for the whole system. As discussed further in Chapter Five, this is a central principle to MCLA. A number of comments reveal learning about and with others - the relational learning effects considered next.

\section{Relational Learning}

This section reports the Forum survey (Survey Two), follow-up survey (Survey One B), and interview findings regarding relational learning effects.

\section{Forum Survey}

At the time of the Forum, respondents were asked to rate their agreement with the following statement: "I made contacts that will be helpful to my work." The mean response was 4.45 on a five-point scale with 5 being "strongly agree." 
Also at the time of the Forum, participants were asked to respond to the following open-ended question: "In what ways do you think that attending this Forum will impact you professionally?" Forty respondents (60\%) identified relational learning effects. For example:

- The networking and partnership will allow me to leverage what I'm able to do... I will call upon many of the organizations I was introduced to.

- Provided a new set of potential collaborators. Broadened my sense of what is possible and what the connections might be with new organizations and issues I hadn't thought of before.

- Great relationship building.

- Networking, built trust.

- It has provided me with contacts and strengthened existing partnerships.

Sixteen participants (25\%) identified relational learning effects when asked: "In what ways do you think that attending this Forum will impact you personally?" Effects identified were similar to those listed above. 


\section{Survey One-B (Follow-up Survey)}

In the follow-up survey (nine months after the Forum), participants were asked: "In what ways do you think that attending the April Food Economy Forum impacted you professionally?" Twenty-eight respondents (70\%) identified relational learning effects. For example:

- Building real, trustworthy friendships and collegial relationships from the public sector.

- Contacts have been invaluable.

- I made some fantastic professional contacts.

- Made professional contacts that would not of otherwise known.

- It helped me to realize there is a larger community interested in and working on many of the same issues as our organization. Provided an opportunity to explore partnerships to work on collaborative projects.

Nine respondents (25\%) identified relational learning effects when asked, "In what ways do you think that attending this Forum will impact you personally?" Effects identified were similar to those above, (e.g., contacts), though also related to inspiration effects detailed below. For example:

- Inspired me enormously and connected me with new and old friends and associates. 
- Understanding that my work of 27 years fits into a larger picture. I am not alone!

\section{Interviews}

Relational learning effects were identified in interviews as well. As noted in the prior section on substantive learning effects, participants learned about each other and respective organizations during this process. Interestingly, for some, this relational learning came not only as participants learned about new organizations but also as they came to understand their own organizations. Examples of relational learning effects include:

I think that's been really valuable. We come from two separate agencies that are sister agencies and have interacted some outside of CFM but it was through CFM that we built really good networks. So, that's been great.

Yeah. For example, I never would have met X, I don't think in a million years [laughs]! But we email all the time and s/he always includes me on some projects. I think that my program and his/hers program are a great fit. So we talk all the time about projects and possible collaboration.

For example, $\mathrm{I}$ became more aware of what $\mathrm{X}$ is doing and vice versa. And as a result of coming in contact with them in the context of CFM we've planned some projects together and have shared advice on how to do our own projects [which drew us into working with another organization]. Both of which have been fruitful. Other examples...well, I became more aware of what the FPC is trying to do...I think that several of the sub-committee's of the FPC have drawn on me for advise... And 
had there not been a place for us, for them to become aware of us as a resource for them, that might not have happened.

You know, I wouldn't still be here in Portland if I hadn't [joined CFM]. So professionally, it really has afforded me some new direction for my own career. I joke with people that I've entered my agrarian phase. And to a great degree, I have... So, involvement in the CFM initiative was an extraordinary opportunity to forge a very broad network for my work... And if I hadn't been in CFM, I wouldn't have met you know, X and I wouldn't [have done this work]... So, you know, it's very helpful for me. Best lunch I ever went to! [laughs]

[In my own organization] We're still trying to work on who we are and kind of what we're doing collaboratively, so I can see where being involved with CFM has actually strengthened my relationships with key partners. It's facilitated communication... Again, the venue of CFM, people who are right next door or one floor up, you'd think it would be otherwise, but we're not. In that case, I'd say it's helped there.

Productive social capital of both a bridging and bonding nature was identified. For example, one interviewee told of a personal connection made at the April Forum where she and another person just "clicked," resulting in "this incredible and very enriching personal relationship." The friendship supported her in healing through a major illness and also contributed to personal and professional involvement in the community. Through the friendship she became a resource person on curricula, wrote a story for a publication, collaborated on a fundraiser, became a CSA host, and identified a guest chef to teach at an event. Another interviewee noted, "I feel supported... I feel like I'm not completely alone in figuring out how to make this work... And just knowing that if I needed to I could call a member... It's not just the 
resource of support and friendship, it's tangible resources that were available that made it easier for me to do this."

\section{$\underline{\text { Summary }}$}

Substantial relational learning effects were evidenced as participants learned about other players in the system, another finding consistent with the literature (e.g., Daniels \& Walker, 1996; Schusler, Decker, \& Pfeffer, 2003; Turcotte \& Pasquero, 2001). This learning impacted respondents' ability to do their job (e.g., more knowledgeably deliver services, have a resource to call upon) and led in some instances to partnerships or collaboration. For some participants, the learning about ways to relate was of a more processual nature. For example, "It made me more of a listener, networker and opened my eyes to more potential." Further, in the member debriefing the notion of leadership development was highlighted. Interviewees noted that their leadership skills were developed through participation in the process - because the relationships made afforded opportunities to grow and because the process modeled relational practices. Turcotte and Pasquero (2001) found that relational learning (e.g., who is who) was cited by participants as a more important outcome than substantive (technical) learning (p. 457). Pelletier (1999a) and Tenkasi and Chesmore (2003) 
similarly attribute much of the success of such interventions to their ability to create social capital - a matter taken up in Chapter Five.

\section{Inspiration}

This section reports the Forum survey (Survey Two), follow-up survey (Survey One B), and interview findings regarding inspirational effects.

\section{Forum Survey}

On the Forum Evaluation survey participants were asked to respond to the following open-ended question, "In what ways do you think that attending this Forum will impact you professionally?" Eleven respondents (16\%) provided responses that reflected a sense of inspiration or commitment. For example:

- The overview and energy was inspiring and supportive.

- Sustain what I do.

- Inspiration to keep going.

- Give me inspiration, energy, and lifetimes of activities to engage in and foster. 
Twenty-four respondents (38\%) made this identification when asked, "In what ways do you think that attending this Forum will impact you personally?" Examples of statements include:

- More reason for hope.

- Gives me hope and energy to keep up the local work.

- It has helped me to look to the positive and to rekindle the optimism that is sometimes lost in day-to-day life.

- Sustain my values and beliefs.

- Inspirational stories that will impact my perspective on my own personal power.

- Increase my commitment.

Survey One-B (Follow-up Survey)

In the follow-up survey (nine months after the Forum), a similar pattern was observed. Six respondents (15\%) identified inspiration effects when asked: "In what ways do you think that attending the April Food Economy Forum impacted you professionally?" For example:

- Reconfirmed my personal commitment. Inspiring. 
- Further inspiration to keep doing the work I'm doing. It filled my heart to see so many other types of professionals caring about the things that are important to me.

- Reinforced my desire to be part of social change.

- It provided me with reinforcement that others care and there is a professional network dedicated to meaningful work and change.

Twenty-three respondents (64\%) identified inspiration or commitment when asked, "In what ways do you think that attending the April Food Economy Forum impacted you personally?" For example:

- It inspired me enormously.

- Felt like part of a movement.

- It gave me hope for our future.

- Provided encouragement to see so many people who share (at least part of) the same vision.

- Inspired me and strengthened my commitment to Food Systems.

- Gave me hope. Made me joyful.

- My enthusiasm and commitment to sustainable agriculture and food system development was renewed. 
Interviews

Similar themes of connection, inspiration, and commitment were identified in the interviews. For example:

I think it provides some morale boosting and inspiration. It's always somewhat uplifting to know that one has compatriots who think about the same thing and who work and struggle with the same thing. And in my first couple of years here, I had sufficient opportunities to come in contact with people in other parts of the country with whom I had that sort of shared experience or that I grew to learn that I had that shared experienced. But it was nice in the context of CFM to know that there were more people in THIS community whose concerns and focus and worldviews overlapped with at least parts of mine or parts of my professional work. So that makes it easier to do the work. You feel like you probably have compatriots.

I think that what CFM does, it certainly does for me at least- create a sense that you know, I'm not working in isolation, that I'm part of something larger and that we're moving toward this kind of- a different system.

It's been spiritually energizing to associate with a group of people with so many varied interests and goals. And appreciate that we really are part of one large system, one larger mission to build a sustainable food system. I appreciate the diversity of politics. The commitment is real apparent. I just like the people.

Knowing like-minded people who really see the greater good, the greater public good, that makes me feel really great to be able to associate with people like that. So, that's the uplifting part. And that's really what you in the end, what you stick with the organization for, because you feel like what you're doing matters and you're uplifted by it. And you see some results.

At the April Forum, I finally felt like this was my community because I met so many people who were interested in the same things I was. 


\section{Summary}

In some regards the identification of substantial connection, inspiration and commitment effects of MCLA participation is an unexpected finding. While the multi-stakeholder literature does speak to creation of common identity and bonds, even unleashing of creativity, this inspirational component is not highlighted. On the other hand, the participant impacts observed in the Future Search events that inspired this research suggest that the findings regarding feelings of connection and inspiration should not be a surprise. The significance of this finding to MCLA theory and community and movement development is considered in greater detail in Chapters Five and Six.

\section{Viewpoint Change}

As noted in the literature review, significant questions have been raised regarding whether participation in MCLA processes lead to viewpoint change and, if so, the types and amount of change that occur. As in sections one to three above, findings from the Forum Survey (Survey Two), follow-up survey (Survey One B), and interviews are presented. This section also presents findings from the statistical 
analysis of Survey One A and One B responses, Factor Analysis, and Cluster Analysis. Findings are synthesized and discussed at the end of the section.

\section{Forum Survey}

At the time of the Forum, respondents were asked to rate the following statement:

"Participating in the Forum helped me clarify my own beliefs and values about sustainable food systems."

$\begin{array}{ccccc}1 & 2 & 3 & 4 & 5 \\ \text { Strongly } & \text { Disagree } & \text { Not } & \text { Agree } & \text { Strongly } \\ \text { Disagree } & & \text { Sure } & & \text { Agree }\end{array}$

The mean response was 4.21 ; the standardized score 80.25 .

At the time of the Forum, participants were also asked on the Forum evaluation survey, "In what ways do you think that attending this Forum will impact you personally?" Seven respondents $(11 \%)$ noted that their beliefs were clarified. For example:

- Better able to clarify my personal beliefs.

- Help me clarify the ways I view and participate in food issues.

- Changes my perspective on looking at agriculture-food production. 
- Caused me to reflect on how my values are being transferred to my actions and how well I'm communicating my values to my children.

- Changed my thoughts on eating habits.

Given the high score on the corresponding Likert scale question, it is possible that this low figure can be attributed to the fact that participants had already answered the question about clarification of beliefs and values and may have felt little need to repeat the information.

\section{Survey One B}

On the post--survey, respondents were asked to rate their agreement with the following, corresponding, statement: Participating in the Forum helped me clarify my own beliefs and values about sustainable food systems.

$\begin{array}{ccccccc}1 & 2 & 3 & 4 & 5 & 6 & 7 \\ \text { Strongly } & \text { Disagree } & \text { Mildly } & \text { Not } & \text { Mildly } & \text { Agree } & \text { Strongly } \\ \text { Disagree } & & \text { Agree } & \text { Sure } & \text { Disagree } & & \text { Disagree }\end{array}$

The mean response was 5.80 ; the standardized score 80 . Kruskal-Wallis and ANOVA tests controlling for amount of Forum attendance found no significant difference between the groups. 
Interviews

Interviewees identified viewpoint effects at the personal level. For example:

I think it's definitely been a good healthy learning experience for me also... it's been very interesting to be challenged to think and see alternative points of view and perspective...[H]aving had a chance to really begin to stop and kind of look and say "Well then what are the ways and ideas that those two perspectives which are both valued begin to be reconciled?" And for me it's beginning to come out in this continuous improvement idea. Where you are you seeing safety, consumer satisfaction, environmental responsibility, social accountability all kind of coming at, in some type of a schema that really can be; you know taking the values from over here and putting them in a schema that can be implemented over here.

I think partly as a result of my participation in CFM I have become more sensitized to the relevance and importance and meaning of very local food systems... I came in contact with more people who are focused on that every day. And so, for me in my own life it made me pay more attention to those things and as I said, it became more front of mind. I heard more people talk about it and think, "Oh wow, I can be more deliberate in my choices as well."

The interviews indicate that individual participants were able to change their thinking about issues and/or people. 


\section{Survey One A and One B Hypothesis Tests}

As described in Chapter Three, pre- and post-survey data was used to examine whether participants in the Forum evidenced a change in beliefs or behaviors. Twelve hypotheses were tested - four considering data collected prior to the Forum, four considering data collected nine months after the Forum, and four considering change data (i.e., differences between pre- and post-survey responses). Potential differences by amount of time at the Forum, work group participation, and gender were explored.

Results for Hypotheses 1 to 12 are presented below, grouped by pre-test, post-test, and difference score evaluations. Results are presented for variables that are significant at the $95 \%$ level for all appropriate tests. Results are also provided for variables that are significant at the $95 \%$ level on one test but significant at the $90 \%$ confidence level for another (i.e., almost the same results with differing tests but not quite); results at the $90 \%$ level are shown in parentheses. A synthesis of results for the three sub-groups follows. 
Pre-Tests

Expecting the Forum and control group to be equivalent prior to the Forum event, Hypothesis One tests for differences between the groups (i.e., Ho $=$ no difference between Forum and non-Forum groups in the pre-survey). Hypothesis Two explores whether Forum participants who attended the Forum for different lengths of time were equivalent prior to the event and tests for differences between the groups (i.e., Ho $=$ no difference by Forum participation all, most, and control in the pre-survey): If postscores reveal a difference between participants based on the length of time they attended the Forum, it is important to consider whether this is attributable to the Forum attendance or whether this group was different prior to the event. Hypothesis Three explores whether respondents who attended the Forum and were part of the work group are equivalent prior to the event with the control group and Forum attendees that were not part of the work group (i.e., $\mathrm{Ho}=$ no difference in the presurvey between Forum with work group participation, Forum without work group participation, and control group): If post-scores reveal a difference between participants based on the work group participation, it is important to consider whether the difference may be attributable to participation in the work group or whether the groups were different prior to the event. Hypothesis Four considers whether men and women scored differently on the pre-survey as the literature indicates gender differences regarding beliefs and behaviors related to food and environment issues 
(DeLind \& Ferguson, 1999; Mohai, 1997; Sachs, 1996; Zelezny, Chua, \& Aldrich, 2000): If post-scores indicate a difference between men and women it is important to consider whether these two groups were similar or different prior to the event, rather than assuming that it was the intervention that impacted them differently.

Hypothesis 1:

Ho There is no difference between Forum and non-Forum groups in the pre-survey. H1 There is a difference between Forum and non-Forum groups in the pre-survey.

Results (Table 9) indicate that the Forum and non-Forum (control) group responses were essentially the same before the Forum. The two groups differed on no more than four of the 71 survey questions (depending on which test was used). There is no prima facie logic for the positive results obtained. It is assumed that these positive results are attributable to random error: at the $95 \%$ confidence level one would expect 3 to 4 false positives $(71 * .05=3.55)$. 
Table 9: Hypothesis 1 Statistically Significant Findings

\begin{tabular}{|l|l|l|l|}
\hline & Mann-Whitney & Independent t & Phi/Cramer's V \\
\hline $\begin{array}{l}\text { Local food prices same } \\
\text { as non-local (8) }\end{array}$ & .034 & .024 & $\mathrm{n} / \mathrm{a}$ \\
\hline $\begin{array}{l}\text { The current food } \\
\text { system maintains } \\
\text { cultural traditions (21) }\end{array}$ & .031 & $(.097)$ & $\mathrm{n} / \mathrm{a}$ \\
\hline Imp. freshness (41) & .044 & & .043 \\
\hline Imp. novelty (41) & & & .028 \\
\hline Source other (43) & $(.094)$ & .008 & $\mathrm{n} / \mathrm{a}$ \\
\hline
\end{tabular}

Hypothesis 2:

Ho There is no difference in pre-survey responses by Forum participation (all, most, control) $)^{4}$.

H1 There is a difference in pre-survey responses by Forum participation (all, most, control).

Hypothesis Two considers whether pre-survey responses are different for participants that stayed at the Forum for different amounts of time (i.e., people who stayed for the full Forum respond differently than people who stayed for part of the Forum).

The omnibus test results indicate that there may be a difference between groups for

\footnotetext{
${ }^{3}$ Survey questions are presented in an abbreviated form in the tables. Survey question numbers are listed in parentheses to facilitate looking up the full text of the Likert statement in Appendix J. As noted above, results are presented for variables that are significant at the $95 \%$ level for all appropriate tests. Results are also provided for variables that are significant at the $95 \%$ level on one test but significant at the $90 \%$ confidence level for another (i.e., almost the same results with differing tests but not quite); results at the $90 \%$ level are shown in parentheses.

"The Forum amount group "little" was removed from analysis of variance given its small size $(n=3)$.
} 
three agree/disagree statements and two sources of home food groceries:

- Children's education should include basic knowledge and skills about growing and preparing food, and the impacts of food choices on themselves, their community, and the environment (17)

- Genetically engineered (genetically modified) foods should not be allowed (26)

- I want to learn more about how food systems - from field to fork - affect economic, environmental, and human health in our community (40)

- Percent of your at home food groceries from the following source in a typical year - source CSA (43).

- Percent of your at home food groceries from the following source in a typical year - farmers' market (43).

Post hocs identified no difference between groups for three of these five questions: 17 (children's education), 26 (no GE), and 43 (source of home groceries farmers market). This may be attributable to low power due to the small sample size, particularly if the treatment effect is quite small, and/or this may be attributable to Type I error for the omnibus test (three to four false positives can be expected at the .05 significance level).

For question 43 (source of home food groceries CSA), the post hoc test identified 
Forum all and Forum most as different at .003 significance, though there is little logic for this finding. For question 40 (I want to learn more), the post hoc test was significant at .09 between Forum all and Forum most. Thus, those that stayed for the full Forum may have been interested in learning more than those that did not. No significant difference between the Forum all group and control group was detected. The control group is comprised of individuals who wanted to attend the Forum but were unable: perhaps they would have stayed for the full Forum had they been able, thus providing a potential logic as to why no difference was identified between Forum all and control when a difference was detected between Forum most and Forum all. Another explanation may be Type I error. Overall, it appears that there was little, if any, significant difference on pre-survey scores between groups of varying Forum attendance.

Table 10a: Hypothesis 2 Statistically Significant Findings

\begin{tabular}{|l|l|l|l|l|l|}
\hline & $\begin{array}{l}\text { Kruskal- } \\
\text { Wallis }\end{array}$ & ANOVA $^{5}$ & $\begin{array}{l}\text { Levene's } \\
\text { Sig. }\end{array}$ & Welch & $\begin{array}{l}\text { Brown- } \\
\text { Forsythe }\end{array}$ \\
\hline $\begin{array}{l}\text { Children's education } \\
\text { should include food system } \\
\text { knowledge and skills (17) }\end{array}$ & .038 & .021 & .000 & & $(.083)$ \\
\hline $\begin{array}{l}\text { Genetically engineered } \\
\text { organisms should not be } \\
\text { allowed in food (26) }\end{array}$ & $(.056)$ & .040 & .363 & & \\
\hline $\begin{array}{l}\text { School food programs } \\
\text { support local health (30) }\end{array}$ & & .040 & .000 & & $(.072)$ \\
\hline $\begin{array}{l}\text { I want to learn more about } \\
\text { food systems (40) }\end{array}$ & .021 & .020 & .077 & & \\
\hline Source farmers' market (43) & & & .029 & .018 & $(.062)$ \\
\hline Source CSA (43) & $(.107)$ & $(.073)$ & .000 & .002 & .016 \\
\hline
\end{tabular}

\footnotetext{
${ }^{5}$ Phi and Cramer's V were run, with no significant measures of association evident.
} 
Table 10b: Hypothesis 2 Statistically Significant Findings

\begin{tabular}{|c|c|c|c|}
\hline & \begin{tabular}{|l} 
All \\
Mean (SD)
\end{tabular} & \begin{tabular}{|l} 
Most \\
Mean (SD)
\end{tabular} & \begin{tabular}{|l|} 
Control \\
Mean (SD)
\end{tabular} \\
\hline $\begin{array}{l}\text { Children's education } \\
\text { should include food } \\
\text { system knowledge and } \\
\text { skills (17) }\end{array}$ & $\begin{array}{l}6.90 \\
(.31)\end{array}$ & $\begin{array}{l}6.45 \\
(.69)\end{array}$ & $\begin{array}{l}6.75 \\
(.45)\end{array}$ \\
\hline $\begin{array}{l}\text { Genetically engineered } \\
\text { organisms should not be } \\
\text { allowed in food ( } 26)\end{array}$ & \begin{tabular}{|l|}
5.55 \\
$(1.88)$
\end{tabular} & \begin{tabular}{|l|}
4.09 \\
$(1.97)$
\end{tabular} & $\begin{array}{l}5.81 \\
(1.47)\end{array}$ \\
\hline $\begin{array}{l}\text { School food programs } \\
\text { support local health }(30)\end{array}$ & $\begin{array}{l}1.59 \\
(.73) \\
\end{array}$ & $\begin{array}{l}1.73 \\
(.79) \\
\end{array}$ & \begin{tabular}{|l|}
.50 \\
$(1.79)$ \\
\end{tabular} \\
\hline $\begin{array}{l}\text { I want to learn more } \\
\text { about food systems }(40)\end{array}$ & $\begin{array}{l}6.76 \\
(.44) \\
\end{array}$ & \begin{tabular}{|l|}
6.27 \\
$(.65)$ \\
\end{tabular} & \begin{tabular}{|l|}
6.31 \\
$(.79)$ \\
\end{tabular} \\
\hline $\begin{array}{l}\text { Source farmers' market } \\
\text { (43) }\end{array}$ & $\begin{array}{l}1.86 \\
(1.22) \\
\end{array}$ & $\begin{array}{ll}1.10 \\
(.57) \\
\end{array}$ & $\begin{array}{l}1.81 \\
(.91) \\
\end{array}$ \\
\hline Source CSA (43) & $\begin{array}{l}1.24 \\
(1.57) \\
\end{array}$ & $\begin{array}{l}.11 \\
(.33) \\
\end{array}$ & $\begin{array}{l}.69 \\
(1.14) \\
\end{array}$ \\
\hline
\end{tabular}

Hypothesis 3:

Ho There is no difference in pre-survey responses by work group participation (work group, non-work group, control).

H1 There is a difference in pre-survey responses by work group participation (work group, non-work group, control).

Hypothesis Three considers whether there is a difference in pre-survey responses of Forum participants that were members of the work group, Forum participants that were not members of the work group, and the control group.

The omnibus test indicates that there may be some differences between groups for question 8 , "In general, when I shop prices for locally grown food are about the same 
as prices for non-locally grown food." No significant difference between groups was detected with the post hoc tests. As noted above, given the sample characteristics, this may be attributable to low power for the post hocs and/or false positives for the omnibus test. Overall, it appears that pre-survey responses do not vary by work group participation.

Table 11a: Hypothesis 3 Statistically Significant Findings

\begin{tabular}{|l|l|l|l|l|l|}
\hline & Kruskal-Wallis & ANOVA & Levene's & Welch & Brown-Forsythe \\
\hline $\begin{array}{l}\text { Local food prices } \\
\text { same as non-local } \\
(8)\end{array}$ & .040 & .032 & .527 & & \\
\hline $\begin{array}{l}\text { School food } \\
\text { programs support } \\
\text { local health (30) }\end{array}$ & .038 & $(.076)$ & .008 & $(.110)$ & $(.109)$ \\
\hline $\begin{array}{l}\text { We are too } \\
\text { dependent on non- } \\
\text { local sources of } \\
\text { food (31) }\end{array}$ & & .000 & & .075 \\
\hline
\end{tabular}

Table 11b: Hypothesis 3 Statistically Significant Findings

\begin{tabular}{|l|l|l|l|}
\hline & $\begin{array}{l}\text { Forum Work group } \\
\text { Mean (SD) }\end{array}$ & $\begin{array}{l}\text { Forum Not Work group } \\
\text { Mean (SD) }\end{array}$ & $\begin{array}{l}\text { Control } \\
\text { Mean (SD) }\end{array}$ \\
\hline $\begin{array}{l}\text { Local food prices } \\
\text { same as non-local (8) }\end{array}$ & 3.83 & 3.11 & 4.31 \\
$(1.53)$ & $1.45)$ & $(1.78)$ \\
\hline $\begin{array}{l}\text { School food } \\
\text { programs support } \\
\text { local health (30) }\end{array}$ & 1.83 & 1.64 & 2.50 \\
$(.94)$ & $(.76)$ & $(1.79)$ \\
\hline $\begin{array}{l}\text { We are too dependent } \\
\text { on non-local sources } \\
\text { of food (31) }\end{array}$ & $\begin{array}{l}5.67 \\
\text { (1.37) }\end{array}$ & $\begin{array}{l}6.50 \\
(1.06)\end{array}$ & 6.31 \\
\hline
\end{tabular}


Hypothesis 4:

Ho There is no difference in pre-survey responses by gender.

H1 There is a difference in pre-survey responses by gender.

Hypothesis Four considers whether there is a difference in pre-survey responses by gender. Clear differences were observed for twelve items (i.e., displayed statistically significant difference at .05 for all measures - Mann-Whitney, Independent $\mathrm{T}$ and, where appropriate, Phi/Cramer's V) (Table 12). These twelve items include:

- Small, local businesses and national corporations are equally viable in our current food system (10)

- The benefits of globalization outweigh the costs (12).

- We are too dependent on non-local sources of food (31).

- It would be risky or dangerous to be dependent on non-local, imported food (34).

- Our government should ensure that businesses are environmentally friendly (36).

- Our government should ensure that businesses pay a living wage (37).

- There should be a vision and strategy to ensure that we have a sustainable food system in our region (39).

- I want to learn more about how food systems - from field to fork - affect economic, environmental, and human health in our community (40). 
- Important of the following to you when making your food purchase decisions - packaging (41).

- Important of the following to you when making your food purchase decisions - healthfulness of product (41).

- Important of the following to you when making your food purchase decisions - wages and conditions (41).

- Percent of your at home food groceries from the following source in a typical year - source CSA (43).

Possible differences were detected for eight items (i.e., significant for some but not all tests). These include:

- Our current food system is socially just (2).

- Food labels should say where the food was grown (24).

- Our current school food programs support local environmental and economic health (30).

- The price of food should reflect its real costs to the environment and human health (35).

- Please rank how important each of the following is to you when making your food purchase decisions -freshness (41).

- Please rank how important each of the following is to you when making your food purchase decisions - locally grown (41). 
- Please rank how important each of the following is to you when making your food purchase decisions -convenient (41).

- Please rank how important each of the following is to you when making your food purchase decisions - organic/sustainable farming methods. (41).

The detected differences seem to indicate that the women respondents are less sanguine about current food system conditions (i.e., lower scores regarding social justice conditions, viability of local businesses, advantages of globalization, and school food and higher scores regarding dependence). These women display a slightly higher sense of social responsibility and food democracy (i.e., higher scores pertaining to labeling where food is from, pricing to reflect true costs, government involvement in environmental health and living wages, desire to learn more about food issues, and need for a vision/strategy). When it comes to food decisions these women appear to care slightly more about health, organic and sustainable practices, local production, packaging, and wages and conditions. They are also more likely to secure food through a CSA and through gleaning. 
Table 12: Hypothesis 4 Statistically Significant Findings

\begin{tabular}{|c|c|c|c|c|c|}
\hline & $\begin{array}{l}\text { Mann- } \\
\text { Whitney }\end{array}$ & Independent $t$ & $\begin{array}{l}\text { Phi/ } \\
\text { Cramer's } \\
\text { V } \\
\end{array}$ & $\begin{array}{l}\text { Mean } \\
\text { (S.D.) } \\
\text { Male } \\
\end{array}$ & $\begin{array}{l}\text { Mean } \\
\text { (S.D.) } \\
\text { Female } \\
\end{array}$ \\
\hline $\begin{array}{l}\text { Our current food system } \\
\text { is socially just ( } 1 \text { ) }\end{array}$ & .043 & $(.051)$ & $\mathrm{n} / \mathrm{a}$ & $\begin{array}{l}2.26 \\
(1.21)\end{array}$ & $\begin{array}{l}1.71 \\
(.98)\end{array}$ \\
\hline $\begin{array}{l}\text { Small, local business are } \\
\text { equally viable }(10)\end{array}$ & .001 & .008 & $\mathrm{n} / \mathrm{a}$ & $\begin{array}{l}2.61 \\
(1.30)\end{array}$ & $\begin{array}{l}1.71 \\
(1.18)\end{array}$ \\
\hline $\begin{array}{l}\text { Benefits of globalization } \\
\text { outweigh the costs (12) }\end{array}$ & .008 & .017 & $\mathrm{n} / \mathrm{a}$ & $\begin{array}{l}2.91 \\
(1.40)\end{array}$ & $\begin{array}{l}2.07 \\
(1.30)\end{array}$ \\
\hline $\begin{array}{l}\text { School food programs } \\
\text { support local health }(30)\end{array}$ & $(.10)$ & .050 & $\mathrm{n} / \mathrm{a}$ & $\begin{array}{l}2.35 \\
(1.60)\end{array}$ & $\begin{array}{l}1.89 \\
(1.17)\end{array}$ \\
\hline $\begin{array}{l}\text { Food labels should say } \\
\text { where food was grown } \\
\text { (24) }\end{array}$ & .056 & $(.08)$ & $\mathrm{n} / \mathrm{a}$ & $\begin{array}{l}6.26 \\
(.81)\end{array}$ & $\begin{array}{l}6.61 \\
(.67)\end{array}$ \\
\hline $\begin{array}{l}\text { We are too dependent on } \\
\text { non-local food (31) }\end{array}$ & .009 & .036 & $\mathrm{n} / \mathrm{a}$ & $\begin{array}{l}5.87 \\
(1.33) \\
\end{array}$ & $\begin{array}{l}6.54 \\
(.90)\end{array}$ \\
\hline $\begin{array}{l}\text { It would be risky to } \\
\text { depend on non-local } \\
\text { food (34) }\end{array}$ & .014 & .022 & $\mathrm{n} / \mathrm{a}$ & $\begin{array}{l}5.43 \\
(1.53)\end{array}$ & $\begin{array}{l}6.31 \\
(1.00)\end{array}$ \\
\hline $\begin{array}{l}\text { Food prices should } \\
\text { reflect true costs }(35)\end{array}$ & .009 & $(.06)$ & $\mathrm{n} / \mathrm{a}$ & $\begin{array}{l}5.91 \\
(1.13)\end{array}$ & $\begin{array}{l}6.45 \\
(1.09)\end{array}$ \\
\hline $\begin{array}{l}\text { Government should } \\
\text { businesses are } \\
\text { environmentally healthy } \\
\text { (36) }\end{array}$ & .035 & .023 & $\mathrm{n} / \mathrm{a}$ & $\begin{array}{l}5.57 \\
(1.38)\end{array}$ & $\begin{array}{l}6.29 \\
(.68)\end{array}$ \\
\hline $\begin{array}{l}\text { Gov should ensure } \\
\text { businesses pay a living } \\
\text { wage ( } 37 \text { ) }\end{array}$ & .005 & .001 & $\mathrm{n} / \mathrm{a}$ & $\begin{array}{l}5.22 \\
(1.57)\end{array}$ & $\begin{array}{l}6.17 \\
(1.00)\end{array}$ \\
\hline $\begin{array}{l}\text { Should be vision- } \\
\text { strategy to ensure a } \\
\text { sustainable regional food } \\
\text { system (39) }\end{array}$ & .013 & .021 & $\mathrm{n} / \mathrm{a}$ & $\begin{array}{l}6.35 \\
(.83)\end{array}$ & $\begin{array}{l}6.80 \\
(.40)\end{array}$ \\
\hline $\begin{array}{l}\text { I want to learn more } \\
\text { about food systems ( } 40 \text { ) }\end{array}$ & .004 & .004 & $\mathrm{n} / \mathrm{a}$ & $\begin{array}{l}6.22 \\
(.74) \\
\end{array}$ & $\begin{array}{l}6.68 \\
(.53) \\
\end{array}$ \\
\hline Imp packaging (41) & .001 & .001 & .013 & $\begin{array}{l}1.57 \\
(.73)\end{array}$ & $\begin{array}{l}2.17 \\
(.67)\end{array}$ \\
\hline $\begin{array}{l}\text { Imp. convenient location } \\
\text { (41) }\end{array}$ & & & .026 & $\begin{array}{l}1.87 \\
(.87)\end{array}$ & $\begin{array}{l}1.98 \\
(.69)\end{array}$ \\
\hline Imp. freshness (41) & .04 & $(.076)$ & .038 & $\begin{array}{l}2.74 \\
(.45)\end{array}$ & $\begin{array}{l}2.90 \\
(.30)\end{array}$ \\
\hline Imp. healthfulness (41) & .014 & .026 & .036 & $\begin{array}{l}2.50 \\
(.60)\end{array}$ & $\begin{array}{l}2.81 \\
(.16)\end{array}$ \\
\hline $\begin{array}{l}\text { Imp org/sust. farming } \\
\text { (41) }\end{array}$ & .026 & .019 & $(.125)$ & $\begin{array}{l}2.13 \\
(.87)\end{array}$ & $\begin{array}{l}2.55 \\
(.67)\end{array}$ \\
\hline Imp. locally grown (41) & .039 & .034 & $(.104)$ & 2.04 & 2.40 \\
\hline
\end{tabular}




\begin{tabular}{|l|l|l|l|l|l|}
\hline & & & & $(.71)$ & $(.63)$ \\
\hline $\begin{array}{l}\text { Imp. wages and } \\
\text { conditions (41) }\end{array}$ & .000 & .00 & .003 & $\begin{array}{l}1.18 \\
(.80)\end{array}$ & $\begin{array}{l}2.05 \\
(.81)\end{array}$ \\
\hline Source CSA (43) & .039 & .006 & $\mathrm{n} / \mathrm{a}$ & $\begin{array}{l}.25 \\
(.64)\end{array}$ & $\begin{array}{l}1.02 \\
(1.50)\end{array}$ \\
\hline Gleaning (43) & & .044 & $\mathrm{n} / \mathrm{a}$ & $\begin{array}{l}.00 \\
(0)\end{array}$ & $\begin{array}{l}.12 \\
(.33)\end{array}$ \\
\hline
\end{tabular}

In summary, at the time of the pre-survey there were no discernible differences between the Forum and control groups, or between the groups whose amount of time at the Forum or work group participation varied. Consistent with the literature, differences were observed between women and men on some beliefs and behaviors regarding food and sustainability issues.

Post-Tests

Expecting there to be a difference between the Forum and control group after the Forum event, Hypothesis Five tests for differences between the groups (i.e., Ho $=$ no difference between Forum and non-Forum groups in the post-survey). Hypothesis Six explores whether post-test scores vary depending upon amount of Forum participation (i.e., Ho $=$ no difference by Forum participation all, most, and control in the postsurvey). Hypothesis Seven explores whether post-test scores vary by work group participation (i.e., $\mathrm{Ho}=$ no difference in the post-survey between Forum attendees with work group participation, Forum attendees without work group participation, and 
control group). Hypothesis Eight considers whether men and women scored differently on the post-survey.

Hypothesis 5:

Ho There is no difference between Forum and non-Forum groups in the post-survey.

H1 There is a difference between Forum and non-Forum groups in the post-survey.

Significant differences were identified between Forum and control groups on five post-survey responses:

- Hunger is a significant issue in our region (6).

- Our current school food programs support local environmental and economic health (30).

- I want to learn more about how food systems - from field to fork - affect economic, environmental, and human health in our community (40).

- Please rank how important each of the following is to you when making your food purchase decisions - taste (41).

- Percent of your at home food groceries from the following source in a typical year - specialty store (43).

Possible differences were detected for two items: 
- Government policies related to transportation, community development, and the environment all affect community food systems (11).

- Please rank how important each of the following is to you when making your food purchase decisions - novelty of item (41).

Items 6 (hunger in the region) and 30 (school food support of local) seem to be reasonable findings as hunger and school food were topics that received a fair amount of attention at the Forum. For "hunger is a significant issue in our region" (6) the mean score rose for Forum participants $(6.59$, s.d. .41 to 6.79 , s.d. .21) and fell for the control group (6.31, s.d. .60 to 6.06 , s.d. 1.13 ), indicating that attendees may have become more aware of the issue through Forum participation and/or that exogenous factors impacted the two groups differently. The same pattern holds for "government policies affect" (11), with attendees posting a mean score increase $(6.69$, s.d. .55 to 6.71 , s.d. .30) and the control group scores evidencing a mean score decrease (6.50, s.d. .82 to 6.25 , s.d. .86 ). The Forum may have sensitized participants to the role of government in shaping food systems. For "Our current school food programs support local environmental and economic health" (30), the mean score stayed the same for Forum participants (1.69, s.d. .80 to 1.69 s.d. .55$)$ and decreased for the control group (2.50, s.d. 1.78 to 2.38 , s.d. 1.72$)$. This may indicate that exogenous factors (e.g., media stories, school food campaigns) impacted the control group differently than participants. However, given the amount of change, this may be attributable to 
random error and/or hold little importance.

With respect to "I want to learn more" (40), the mean score declined for both the Forum group (6.57, s.d. .58 to 6.29, s.d..82) and the control group $(6.31$, s.d. .79 to 5.75, s.d. 1.07), though with a larger decrease for the control group; a significant difference between groups was observed on the post-test. It may be that as food system issues were gaining increased coverage in the community during this time period saturation was occurring and the desire to learn more decreased - though less in Forum attendees who, having given positive reviews of the Forum, may have found that such venues stimulated interest in learning for some participants.

There is little prima facie logic for the finding of significant difference in post-scores between Forum and control groups for taste, novelty, and specialty store (41 and 43). These findings may be attributable to error and/or hold little significance.

Table 13a: Hypothesis 5 Statistically Significant Findings

\begin{tabular}{|l|l|l|l|}
\hline & Mann-Whitney & Independent t & Phi/Cramer's V \\
\hline $\begin{array}{l}\text { Hunger is a significant } \\
\text { issue in our region (6) }\end{array}$ & .002 & .016 & $\mathrm{n} / \mathrm{a}$ \\
\hline $\begin{array}{l}\text { Gov policies affect } \\
\text { community food } \\
\text { systems (11) }\end{array}$ & .020 & $(.059)$ & $\mathrm{n} / \mathrm{a}$ \\
\hline $\begin{array}{l}\text { School food programs } \\
\text { support local health } \\
(30)\end{array}$ & .038 & .012 & $\mathrm{n} / \mathrm{a}$ \\
\hline $\begin{array}{l}\text { I want to learn more } \\
\text { about food systems }\end{array}$ & .042 & .039 & $\mathrm{n} / \mathrm{a}$ \\
\hline
\end{tabular}




\begin{tabular}{|l|l|l|l|}
\hline$(40)$ & & & \\
\hline Important taste (41) & .030 & .029 & .029 \\
\hline Specialty store (43) & .038 & .016 & $\mathrm{n} / \mathrm{a}$ \\
\hline Important novelty (41) & & & .012 \\
\hline
\end{tabular}

Table 13b: Hypothesis 5 Statistically Significant Findings

\begin{tabular}{|l|l|l|}
\hline & $\begin{array}{l}\text { Forum } \\
\text { Mean (SD) }\end{array}$ & $\begin{array}{l}\text { Control } \\
\text { Mean (SD) }\end{array}$ \\
\hline Hunger is a significant issue in & 6.79 & 6.06 \\
our region (6) & $(.46)$ & $(1.06)$ \\
\hline Gov Policies affect & 6.71 & 6.25 \\
community food systems (11) & $(.54)$ & $(.86)$ \\
\hline School food programs support & 1.69 & 2.38 \\
local health (30) & $(.74)$ & $(1.31)$ \\
\hline I want to learn more about & 6.29 & 5.75 \\
food systems (40) & $(.82)$ & $(1.06)$ \\
\hline Important taste (41) & 2.73 & 2.44 \\
& $(.45)$ & $(.51)$ \\
\hline Important novelty (41) & .40 & .81 \\
& $(.54)$ & $(.83)$ \\
\hline Specialty store (43) & 1.23 & 2.0 \\
& $(.92)$ & $(1.31)$ \\
\hline
\end{tabular}

Hypothesis 6:

Ho There is no difference in post-survey responses by Forum participation (all, most, control).

H1 There is a difference in post-survey responses by Forum participation (all, most, control).

Omnibus tests indicate significant difference between groups for significance of hunger in our region (6) and percent of at home food groceries sourced from specialty stores (43), and possibly for importance of taste and importance of organic/sustainable farming methods when making food purchase decisions (41) and percent of at home 
food groceries sourced from CSA (43). The post hocs identified significant differences for significance of hunger in our region (6) and source specialty store and source CSA (43).

The Games-Howell post hoc test identified significant difference between Forum all and control for significance of hunger in our region (6) (.032). As the topic of hunger received a fair amount of attention at the Forum it is reasonable to expect that there may be differences between groups; however, it would be expected that if there were a difference between the control group and Forum all, there would also be a difference for the control group and Forum most. The mean post scores were $6.06(1.1)$ for the control group and 6.83 (.38) for Forum all, with Forum most being in the middle at 6.64 (.67). Comparing pre- and post-survey scores, the Forum all and Forum most participants evidenced an increase in mean score for hunger significant $(6.60, .68$ to $6.83, .38$ and $6.55, .69$ to $6.64, .67$ respectively), while the control group evidenced a decrease in mean score for this item $(6.31, .60$ to $6.06,1.06)$. The difference between Forum most and control may be too small to be detected, or respondents attending the full Forum may have been impacted differently than those attending most of the Forum.

The Games-Howell post hoc test identified significant difference between Forum all and control for source specialty store (43) (.05). Mean scores for source specialty 
store were 2 (s.d., 1.31) for the control group and 1.04 (s.d. .89) for Forum all (roughly $11 \%$ to $25 \%$ of food purchases for the first group and $1 \%$ to $10 \%$ for the second). The Games-Howell post hoc test identified significant difference between Forum all and Forum most for source CSA (43) (.003). Mean scores for source CSA were 1.08 Forum all (s.d. 1.44) and 0 (s.d. 0) for Forum most (with 1 being the range $11 \%$ to $25 \%$ ). There is no prima facie logic for a difference between groups on source specialty store or source CSA; these findings and the lack of identified difference on the other post hocs for importance of taste and importance of organic/sustainable farming methods when making food purchase decisions (41) may be attributable to low power due to sample characteristics or random error, and/or may hold little import.

Table 14a: Hypothesis 6 Statistically Significant Findings

\begin{tabular}{|l|l|l|l|l|l|l|}
\hline & $\begin{array}{l}\text { Kruskal- } \\
\text { Wallis }\end{array}$ & ANOVA & Levene's & Welch & $\begin{array}{l}\text { Brown- } \\
\text { Forsythe }\end{array}$ & $\begin{array}{l}\text { Phi/ } \\
\text { Cramer's } \\
\text { V }\end{array}$ \\
\hline $\begin{array}{l}\text { Hunger } \\
\text { is a } \\
\text { significant } \\
\text { issue in our } \\
\text { region (6) }\end{array}$ & .012 & .004 & .001 & .037 & .015 & $\mathrm{n} / \mathrm{a}$ \\
\hline $\begin{array}{l}\text { Imp org/sust } \\
\text { farm (41) }\end{array}$ & .043 & $(.082)$ & .796 & & & \\
\hline $\begin{array}{l}\text { Imp. taste } \\
\text { (41) }\end{array}$ & .047 & .044 & .017 & $(.062)$ & $(.065)$ & .042 \\
\hline $\begin{array}{l}\text { Source spec } \\
\text { store (43) }\end{array}$ & .035 & .020 & .201 & & $\mathbf{n} / \mathbf{a}$ \\
\hline $\begin{array}{l}\text { Source CSA } \\
\text { (43) }\end{array}$ & .014 & $(.089)$ & .000 & - & $\begin{array}{l}\text { - (at least } \\
\text { one group } \\
\text { with 0 } \\
\text { variance) }\end{array}$ & n/a \\
\hline
\end{tabular}


Table 14b: Hypothesis 6 Statistically Significant Findings

\begin{tabular}{|l|l|l|l|}
\hline & All & Most & Control \\
\hline $\begin{array}{l}\text { Hunger } \\
\text { is a significant issue in } \\
\text { our region (6) }\end{array}$ & 6.83 & 6.64 & 6.06 \\
& $(.38)$ & $(.67)$ & $(1.06)$ \\
\hline Imp org/sust farm (41) & 2.60 & & \\
\hline Imp. Taste (41) & $(.72)$ & 2.09 & 2.19 \\
& 2.77 & $(.83)$ & $(.75)$ \\
\hline Source spec store (43) & $(.43)$ & 2.44 & 2.44 \\
& 1.04 & $.51)$ & $(.51)$ \\
\hline Source CSA (43) & $(.89)$ & 1.80 & 2.00 \\
& 1.08 & $(1.14)$ & $(1.31)$ \\
\hline
\end{tabular}

Hypothesis 7:

Ho There is no difference in post-survey responses by work group participation (work group, non-work group, control).

H1 There is a difference in post-survey responses by work group participation (work group, non-work group, control).

Omnibus tests indicated significant difference for three items:

- Hunger is a significant issue in our region (6).

- In general, when I shop, prices for locally grown food are about the same as prices for non-locally grown food (8).

- In general, when I shop, prices for organic and sustainably grown food are about the same as prices for other food (9). 
Possibly significant differences were identified for:

- Our current school food programs support local environmental and economic health (30).

- I want to learn more about how food systems - from field to fork - affect economic, environmental, and human health in our community (40).

Significant differences between groups were identified with post hoc tests for items 6 (hunger significant in the region), 8 (local same price), and 9 (organic/sustainable same price). The post hocs did not detect significant difference for item 30 (school food supports local health) or item 40 (I want to learn more), suggesting either Type II error (low power due to sample characteristics, alpha level, etc.) or random error in the omnibus test.

For item 6 (hunger significant) post hocs were significant between the control and Forum non-work group at .039 and between the control group and Forum work group at .074. Significant difference on the item "Hunger is a significant issue in our region" seems to be a reasonable finding: Hunger was a topic that received a fair amount of attention at the Forum, and a representative of the Oregon Food Bank and a representative of Growing Gardens - both groups that serve food needs of low income populations - participated in the work group. However, given the results of Hypothesis Six and the lack of a detected difference between Forum Yes Work Group 
and Forum No Work Group, this finding may be attributable to Forum participation rather than work group participation.

For item 8 (local food costs the same as non-local) post hocs were significant between Forum Yes Work Group and Forum No Work Group at .001, and Forum Yes Work Group and control at .004 . This pattern was closely repeated for item 9 (organic/sustainable priced the same as non), with significance at .027 for Forum Yes Work Group and Forum No Work Group and .124 for Forum Yes Work Group and control. The work group participants evidenced more agreement (mildly agree versus mildly disagree/not sure) that locally grown foods are about the same price as nonlocally grown foods (8), and slightly less disagreement that organic and sustainably grown foods are about the same prices as other foods (9) (mildly disagree to not sure versus disagree to mildly disagree). Further, the work group participants evidenced a much larger change in score on these items than the other two groups (3.83 to 5.08 on "local priced same" and 2.50 to 3.58 on "organic/sustainable priced same" compared to 3.11 to 3.56 and 2.19 to 2.33 for Forum No Work Group and 4.31 to 3.69 and 2.31 to 2.69 for control). As this topic was not a major theme addressed by the work group it may be that this finding relates to characteristics of the work group participants rather than the effects of participation in the work group. 
Table 15a: Hypothesis 7 Statistically Significant Findings

\begin{tabular}{|l|l|l|l|l|l|}
\hline & Kruskal-Wallis & ANOVA & Levene's & Welch & Brown-Forsythe \\
\hline $\begin{array}{l}\text { Hunger } \\
\text { is a significant } \\
\text { issue in our } \\
\text { region (6) }\end{array}$ & .007 & .001 & .001 & .047 & .009 \\
\hline $\begin{array}{l}\text { Local food } \\
\text { prices same as } \\
\text { non-local (8) }\end{array}$ & .003 & .003 & .098 & .001 & .001 \\
\hline $\begin{array}{l}\text { Org/sustainably } \\
\text { grown food } \\
\text { prices are the } \\
\text { same as other } \\
\text { (9) }\end{array}$ & .002 & .001 & .004 & .018 & .006 \\
\hline $\begin{array}{l}\text { School food } \\
\text { programs } \\
\text { support local } \\
\text { health (30) }\end{array}$ & $(.073)$ & .026 & .128 & $(.099)$ & $(.067)$ \\
\hline $\begin{array}{l}\text { I want to learn } \\
\text { more about } \\
\text { food systems } \\
\text { (40) }\end{array}$ & .036 & $(.103)$ & .171 & & \\
\hline
\end{tabular}

Table 15b: Hypothesis 7 Statistically Significant Findings

\begin{tabular}{|c|c|c|c|}
\hline & $\begin{array}{l}\text { Forum Work group } \\
\text { Mean (SD) }\end{array}$ & $\begin{array}{l}\text { Forum Not Work } \\
\text { group } \\
\text { Mean (SD) }\end{array}$ & $\begin{array}{l}\text { Control } \\
\text { Mean (SD) }\end{array}$ \\
\hline $\begin{array}{l}\text { Hunger } \\
\text { is a significant issue } \\
\text { in our region (6) }\end{array}$ & $\begin{array}{l}6.74 \\
(.45)\end{array}$ & $\begin{array}{l}6.81 \\
(.47)\end{array}$ & $\begin{array}{l}6.06 \\
(1.06)\end{array}$ \\
\hline $\begin{array}{l}\text { Local food prices } \\
\text { same as non-local }(8)\end{array}$ & $\begin{array}{l}5.08 \\
(1.0)\end{array}$ & $\begin{array}{l}3.56 \\
(1.44)\end{array}$ & $\begin{array}{l}3.69 \\
(1.08)\end{array}$ \\
\hline $\begin{array}{l}\text { Org/sustainably } \\
\text { grown food prices are } \\
\text { the same as other }(9)\end{array}$ & $\begin{array}{l}3.58 \\
(1.38)\end{array}$ & $\begin{array}{l}2.33 \\
(.86)\end{array}$ & $\begin{array}{l}2.69 \\
(.60)\end{array}$ \\
\hline $\begin{array}{l}\text { School food programs } \\
\text { support local health } \\
(30)\end{array}$ & $\begin{array}{l}1.92 \\
(.90)\end{array}$ & $\begin{array}{l}1.62 \\
(.68)\end{array}$ & $\begin{array}{l}2.38 \\
(.131)\end{array}$ \\
\hline $\begin{array}{l}\text { I want to learn more } \\
\text { about food systems } \\
\text { (40) }\end{array}$ & $\begin{array}{l}6.42 \\
(1.24)\end{array}$ & $\begin{array}{l}6.25 \\
(.65)\end{array}$ & $\begin{array}{l}5.75 \\
(1.07)\end{array}$ \\
\hline
\end{tabular}


Hypothesis 8:

Ho There is no difference in post-survey responses by gender.

H1 There is a difference in post-survey responses by gender.

Hypothesis Eight considers whether there is a difference in post-survey responses by gender. Clear differences were observed for nineteen items (three more than on presurvey) (i.e., displayed statistically significant difference of .05 for all measures Mann-Whitney, Independent T and, where appropriate, Phi/Cramer's V). Nine of these items were identified as significant (7) or possibly significant (2) on the presurvey. These include:

- Small, local businesses and national corporations are equally viable in our current food system (10).

- Our current school food programs support local environmental and economic health (30).

- We are too dependent on non-local sources of food (31).

- It would be risky or dangerous to be dependent on non-local, imported food (34).

- Our government should ensure that businesses pay a living wage (37).

- There should be a vision and strategy to ensure that we have a sustainable food system in our region (39). 
- Please rank how important each of the following is to you when making your food purchase decisions - healthfulness of product (41).

- Please rank how important each of the following is to you when making your food purchase decisions - wages and conditions (41).

- Please rank how important each of the following is to you when making your food purchase decisions - locally grown (41).

Ten identified items were "new differences" (i.e., were not identified as significantly different or possibly significantly different on the pre-survey, Hypothesis Four).

These include:

- Our current food system promotes community health (3).

- In general, I make healthy food choices (4).

- Our region is losing small, locally owned businesses (18).

- We have a duty to future generations to leave the earth in as good or better shape than we found it (32).

- In the long run, we can't have a healthy economy without a healthy environment (33).

- Please rank how important each of the following is to you when making your food purchase decisions - shop is locally owned (41).

- Percent of your at home food groceries from the following source in a typical year - source someone else's home garden (43). 
- Percent of your at home food groceries from the following source in a typical year - source u-pick (43).

- Percent of your at home food groceries from the following source in a typical year - source discount food outlet (43).

- Percent of your at home food groceries from the following source in a typical year - source gleaning (43).

Four items identified as significantly different on the pre-survey were not identified as significantly different or possibly significantly different on the post-survey: Our government should ensure that businesses are environmentally friendly (36), I want to learn more about how food systems - from field to fork - affect economic, environmental, and human health in our community (40), Importance of the following to you when making your food purchase decisions - packaging (41), Percent of your at home food groceries from the following source in a typical year-source CSA (43).

Possible differences were detected for eight items (i.e., significant for some but not all tests). These include:

- Our current food system is socially just (2).

- Access to food is a basic human right (19).

- Food labels should say where the food was grown (24).

- Our current school food programs are healthy for students (29). 
- The price of food should reflect its real costs to the environment and human health (35).

- Please rank how important each of the following is to you when making your food purchase decisions -freshness (41).

- Please rank how important each of the following is to you when making your food purchase decisions -convenient (41).

- Please rank how important each of the following is to you when making your food purchase decisions - organic/sustainable farming methods. (41).

As in the pre-survey, the direction and strength of scores are similar between men and women, though the detected differences seem to indicate that the women surveyed are less sanguine about current food system conditions (lower scores for items 3, 10, 12, $23,29,30$ and higher scores for items 18,31 , and 34 ). These women display a slightly higher sense of social responsibility and food democracy (items 19, 25, 32, 37, and 39). When it comes to food decisions, the women surveyed have a slightly stronger sense of their knowledge and skills regarding healthy food choices and appear to care slightly more about health, organic and sustainable practices, local production and ownership, and wages and conditions when making purchase decisions (items 4,14 , and 41). They are also more likely to secure food through others' gardens, farm stands and u-picks, discount outlets and gleaning (item 43). 
Table 16a: Hypothesis 8 Statistically Significant Findings

\begin{tabular}{|c|c|c|c|c|c|}
\hline & $\begin{array}{l}\text { Mann- } \\
\text { Whitney }\end{array}$ & Indep. $t$ & $\begin{array}{l}\text { Phi/ } \\
\text { Cramer's } \\
\text { V }\end{array}$ & $\begin{array}{l}\text { Mean } \\
\text { Male }\end{array}$ & $\begin{array}{l}\text { Mean } \\
\text { Female }\end{array}$ \\
\hline $\begin{array}{l}\text { Current system promotes } \\
\text { community health ( } 3 \text { ) }\end{array}$ & .03 & .026 & $\mathrm{n} / \mathrm{a}$ & $\begin{array}{l}2.48 \\
(1.12)\end{array}$ & $\begin{array}{l}1.90 \\
(.89)\end{array}$ \\
\hline $\begin{array}{l}\text { Generally make healthy food } \\
\text { choices (4) }\end{array}$ & .046 & .031 & $\mathrm{n} / \mathrm{a}$ & $\begin{array}{l}5.43 \\
(1.27)\end{array}$ & $\begin{array}{l}6.07 \\
(.56)\end{array}$ \\
\hline $\begin{array}{l}\text { Small, local business are } \\
\text { equally viable }(10)\end{array}$ & .001 & .003 & $\mathrm{n} / \mathrm{a}$ & $\begin{array}{l}3.09 \\
(1.78)\end{array}$ & $\begin{array}{l}1.75 \\
(1.30) \\
\end{array}$ \\
\hline $\begin{array}{l}\text { Benefits of globalization } \\
\text { outweigh the costs (12) }\end{array}$ & .042 & $(.066)$ & $\mathrm{n} / \mathrm{a}$ & $\begin{array}{l}2.96 \\
(1.58)\end{array}$ & $\begin{array}{l}2.24 \\
(1.40) \\
\end{array}$ \\
\hline $\begin{array}{l}\text { I have knowledge/skill to make } \\
\text { healthy food choices (14) }\end{array}$ & $(.078)$ & .039 & $\mathrm{n} / \mathrm{a}$ & $\begin{array}{l}6.22 \\
(.95) \\
\end{array}$ & $\begin{array}{l}6.61 \\
(.54) \\
\end{array}$ \\
\hline $\begin{array}{l}\text { Region losing small, local } \\
\text { businesses (18) }\end{array}$ & .024 & .024 & $\mathrm{n} / \mathrm{a}$ & $\begin{array}{l}5.52 \\
(1.38) \\
\end{array}$ & $\begin{array}{l}6.00 \\
(1.10) \\
\end{array}$ \\
\hline Food access basic right (19) & .035 & $(.094)$ & $\mathrm{n} / \mathrm{a}$ & $\begin{array}{l}6.39 \\
(1.31)\end{array}$ & $\begin{array}{l}6.70 \\
(.87)\end{array}$ \\
\hline $\begin{array}{l}\text { Food prices reflect true cost } \\
(23)\end{array}$ & .033 & & $\mathrm{n} / \mathrm{a}$ & $\begin{array}{l}1.52 \\
(.59) \\
\end{array}$ & $\begin{array}{l}1.38 \\
(.86) \\
\end{array}$ \\
\hline $\begin{array}{l}\text { GE foods should be labeled } \\
(25)\end{array}$ & .047 & & $\mathrm{n} / \mathrm{a}$ & $\begin{array}{l}6.09 \\
(1.51)\end{array}$ & $\begin{array}{l}6.55 \\
(1.15) \\
\end{array}$ \\
\hline $\begin{array}{l}\text { Current school food programs } \\
\text { are healthy for students (29) }\end{array}$ & .033 & $(.060)$ & $\mathrm{n} / \mathrm{a}$ & $\begin{array}{l}2.57 \\
(1.47)\end{array}$ & $\begin{array}{l}1.88 \\
(1.13) \\
\end{array}$ \\
\hline $\begin{array}{l}\text { School food programs support } \\
\text { local health }(30)\end{array}$ & .001 & .002 & $\mathbf{n} / \mathbf{a}$ & $\begin{array}{l}2.35 \\
(1.11) \\
\end{array}$ & $\begin{array}{l}1.60 \\
(.73) \\
\end{array}$ \\
\hline $\begin{array}{l}\text { We are too dependent on non- } \\
\text { local food ( } 31)\end{array}$ & .009 & .024 & $\mathrm{n} / \mathrm{a}$ & $\begin{array}{l}5.65 \\
(1.53) \\
\end{array}$ & $\begin{array}{l}6.48 \\
(.92) \\
\end{array}$ \\
\hline Duty future generations (32) & .014 & .036 & $\mathrm{n} / \mathrm{a}$ & $\begin{array}{l}6.70 \\
(.47) \\
\end{array}$ & $\begin{array}{l}6.93 \\
(.26) \\
\end{array}$ \\
\hline $\begin{array}{l}\text { Healthy econ needs healthy } \\
\text { environment (33) }\end{array}$ & .030 & .040 & $\mathrm{n} / \mathrm{a}$ & $\begin{array}{l}6.39 \\
(.94) \\
\end{array}$ & $\begin{array}{l}6.83 \\
(.38) \\
\end{array}$ \\
\hline $\begin{array}{l}\text { It would be risky to depend on } \\
\text { non-local food (34) }\end{array}$ & .029 & .021 & $\mathrm{n} / \mathrm{a}$ & $\begin{array}{l}5.39 \\
(1.83) \\
\end{array}$ & $\begin{array}{l}6.38 \\
(.85) \\
\end{array}$ \\
\hline $\begin{array}{l}\text { Gov should ensure businesses } \\
\text { pay a living wage ( } 37 \text { ) }\end{array}$ & .018 & .017 & $\mathrm{n} / \mathrm{a}$ & $\begin{array}{l}5.13 \\
(1.63) \\
\end{array}$ & $\begin{array}{l}6.07 \\
(.96) \\
\end{array}$ \\
\hline Should be a vision strategy (39) & .000 & .006 & $\mathrm{n} / \mathrm{a}$ & $\begin{array}{l}5.87 \\
(1.33) \\
\end{array}$ & $\begin{array}{l}6.74 \\
(.50) \\
\end{array}$ \\
\hline Imp. healthfulness (41) & .001 & .003 & .003 & $\begin{array}{l}2.35 \\
(.65) \\
\end{array}$ & $\begin{array}{l}2.83 \\
(.38) \\
\end{array}$ \\
\hline Imp org/sust. farming (41) & .043 & .035 & & $\begin{array}{l}2.09 \\
(.85) \\
\end{array}$ & $\begin{array}{l}2.50 \\
(.67)\end{array}$ \\
\hline Imp. locally grown (41) & .007 & .006 & .023 & $\begin{array}{l}2.09 \\
(.67)\end{array}$ & $\begin{array}{l}2.55 \\
(.59)\end{array}$ \\
\hline Imp. Shop locally owned (41) & .005 & .006 & .024 & 1.57 & 2.33 \\
\hline
\end{tabular}




\begin{tabular}{|l|l|l|l|l|l|}
\hline & & & & $(1.08)$ & $(.80)$ \\
\hline Imp. wages and conditions (41) & .002 & .001 & .012 & $\begin{array}{l}1.36 \\
(.85)\end{array}$ & $\begin{array}{l}2.13 \\
(.80)\end{array}$ \\
\hline Source other garden (43) & .001 & .001 & $\mathrm{n} / \mathrm{a}$ & $\begin{array}{l}.48 \\
(.51)\end{array}$ & $\begin{array}{l}1.03 \\
(.61)\end{array}$ \\
\hline Source f-stand/upick (43) & .029 & .047 & $\mathrm{n} / \mathrm{a}$ & $\begin{array}{l}.79 \\
(.42)\end{array}$ & $\begin{array}{l}1.14 \\
(.68)\end{array}$ \\
\hline Source discount outlet (43) & .023 & .009 & $\mathrm{n} / \mathrm{a}$ & 0 & .38 \\
& & & & $(0)$ & $(.89)$ \\
\hline Source Gleaning (43) & .014 & .010 & $\mathrm{n} / \mathrm{a}$ & 0 & .26 \\
& & & & $(0)$ & $(.51)$ \\
\hline
\end{tabular}

Table 16b: Hypothesis 8 Statistically Significant Findings

\begin{tabular}{|c|c|c|c|c|c|c|}
\hline & Male & & $\%$ & Female & & $\%$ \\
\hline & Pre & Post & Change & Pre & Post & Change \\
\hline $\begin{array}{l}\text { Promote } \\
\text { community } \\
\text { health (3) }\end{array}$ & $\begin{array}{l}2.22 \\
(1.04)\end{array}$ & $\begin{array}{l}2.48 \\
(1.12)\end{array}$ & 12.73 & $\begin{array}{l}1.83 \\
(.87)\end{array}$ & $\begin{array}{l}1.90 \\
(.89)\end{array}$ & 5.56 \\
\hline $\begin{array}{l}\text { Make healthy } \\
\text { choices (4) }\end{array}$ & $\begin{array}{l}5.48 \\
(1.20)\end{array}$ & $\begin{array}{l}5.43 \\
(1.27)\end{array}$ & -0.91 & $\begin{array}{l}5.98 \\
(.85)\end{array}$ & $\begin{array}{l}6.07 \\
(.56)\end{array}$ & 2.88 \\
\hline $\begin{array}{l}\text { Small local } \\
\text { business equally } \\
\text { viable(10) }\end{array}$ & $\begin{array}{l}2.61 \\
(1.31)\end{array}$ & $\begin{array}{l}3.09 \\
(1.78)\end{array}$ & 18.39 & $\begin{array}{l}1.73 \\
(1.18)\end{array}$ & $\begin{array}{l}1.75 \\
(1.30)\end{array}$ & 1.16 \\
\hline $\begin{array}{l}\text { Globalization } \\
\text { benefits } \\
\text { outweigh costs } \\
\text { (12) }\end{array}$ & $\begin{array}{l}2.91 \\
(1.38)\end{array}$ & $\begin{array}{l}2.96 \\
(1.58)\end{array}$ & 1.72 & $\begin{array}{l}2.07 \\
(1.30)\end{array}$ & $\begin{array}{l}2.24 \\
(1.40)\end{array}$ & 8.21 \\
\hline $\begin{array}{l}\text { I have } \\
\text { knowledge/skills } \\
\text { to make healthy } \\
\text { food choices } \\
\text { (14) }\end{array}$ & $\begin{array}{l}6.09 \\
(1.13)\end{array}$ & $\begin{array}{l}6.22 \\
(.95)\end{array}$ & 2.13 & $\begin{array}{l}6.45 \\
(.67)\end{array}$ & $\begin{array}{l}6.61 \\
(.54)\end{array}$ & 2.48 \\
\hline $\begin{array}{l}\text { Region losing } \\
\text { small, local } \\
\text { biz(18) }\end{array}$ & $\begin{array}{l}5.74 \\
(1.25)\end{array}$ & $\begin{array}{l}5.52 \\
(1.38)\end{array}$ & -3.83 & $\begin{array}{l}6.15 \\
(1.11)\end{array}$ & $\begin{array}{l}6.00 \\
(1.10)\end{array}$ & -2.28 \\
\hline $\begin{array}{l}\text { Food access } \\
\text { basic right (19) }\end{array}$ & $\begin{array}{l}6.39 \\
(1.12)\end{array}$ & $\begin{array}{l}6.39 \\
(1.31)\end{array}$ & 0.00 & $\begin{array}{l}6.66 \\
(.94)\end{array}$ & $\begin{array}{l}6.70 \\
(.87)\end{array}$ & 0.90 \\
\hline $\begin{array}{l}\text { Food prices } \\
\text { reflect true cost } \\
\text { (23) }\end{array}$ & $\begin{array}{l}1.65 \\
(.71)\end{array}$ & $\begin{array}{l}1.52 \\
(.59)\end{array}$ & -7.88 & $\begin{array}{l}1.50 \\
(1.09)\end{array}$ & $\begin{array}{l}1.38 \\
(.86)\end{array}$ & -10.39 \\
\hline Label GE (25) & $\begin{array}{l}6.22 \\
(1.31)\end{array}$ & $\begin{array}{l}6.09 \\
(1.51) \\
\end{array}$ & -2.09 & $\begin{array}{l}6.61 \\
(1.06)\end{array}$ & $\begin{array}{l}6.55 \\
(1.15) \\
\end{array}$ & -0.91 \\
\hline $\begin{array}{l}\text { School food } \\
\text { healthy for } \\
\text { students (29) }\end{array}$ & $\begin{array}{l}2.22 \\
(1.58)\end{array}$ & $\begin{array}{l}2.57 \\
(1.47)\end{array}$ & 15.77 & $\begin{array}{l}2.02 \\
(1.33)\end{array}$ & $\begin{array}{l}1.88 \\
(1.13)\end{array}$ & -6.93 \\
\hline
\end{tabular}




\begin{tabular}{|c|c|c|c|c|c|c|}
\hline $\begin{array}{l}\text { School food } \\
\text { supports local } \\
\text { health (30) }\end{array}$ & \begin{tabular}{|l|}
2.35 \\
$(1.58)$
\end{tabular} & $\begin{array}{l}2.35 \\
(1.11)\end{array}$ & 0.00 & $\begin{array}{l}1.63 \\
(.77)\end{array}$ & $\begin{array}{l}1.60 \\
(.73)\end{array}$ & -1.84 \\
\hline $\begin{array}{l}\text { Dependent non- } \\
\text { local (31) }\end{array}$ & $\begin{array}{l}5.87 \\
(1.33)\end{array}$ & $\begin{array}{l}5.65 \\
(1.53)\end{array}$ & -3.75 & $\begin{array}{l}6.54 \\
(.90)\end{array}$ & $\begin{array}{l}6.48 \\
(.92)\end{array}$ & -0.92 \\
\hline $\begin{array}{l}\text { Duty future } \\
\text { generations (32) }\end{array}$ & $\begin{array}{l}6.74 \\
(.54) \\
\end{array}$ & $\begin{array}{l}6.70 \\
(.47)\end{array}$ & -0.59 & $\begin{array}{l}6.93 \\
(.27) \\
\end{array}$ & $\begin{array}{l}6.93 \\
(.26)\end{array}$ & 0.00 \\
\hline $\begin{array}{l}\text { Healthy } \\
\text { economy needs } \\
\text { healthy } \\
\text { environment } \\
\text { (33) }\end{array}$ & $\begin{array}{l}6.61 \\
(.78)\end{array}$ & $\begin{array}{l}6.39 \\
(.94)\end{array}$ & -3.33 & $\begin{array}{l}6.73 \\
(.64)\end{array}$ & $\begin{array}{l}6.83 \\
(.38)\end{array}$ & 1.49 \\
\hline $\begin{array}{l}\text { Risky to depend } \\
\text { on imports (34) }\end{array}$ & \begin{tabular}{|l|}
5.43 \\
$(1.53)$
\end{tabular} & $\begin{array}{l}5.39 \\
(1.83)\end{array}$ & -0.74 & $\begin{array}{l}6.31 \\
(1.01)\end{array}$ & $\begin{array}{l}6.38 \\
(.85)\end{array}$ & 1.11 \\
\hline $\begin{array}{l}\text { Gov. ensure } \\
\text { living wage (37) }\end{array}$ & \begin{tabular}{|l|}
5.22 \\
$(1.57)$
\end{tabular} & $\begin{array}{l}5.13 \\
(1.63)\end{array}$ & -1.72 & $\begin{array}{l}6.17 \\
(.87)\end{array}$ & $\begin{array}{l}6.07 \\
(.96)\end{array}$ & -1.62 \\
\hline $\begin{array}{l}\text { Should be a } \\
\text { vision strategy } \\
\text { (39) }\end{array}$ & $\begin{array}{l}6.35 \\
(.83)\end{array}$ & $\begin{array}{l}5.87 \\
(1.33)\end{array}$ & -7.56 & $\begin{array}{l}6.8 \\
(.41)\end{array}$ & $\begin{array}{l}6.74 \\
(.50)\end{array}$ & \begin{tabular}{|c|}
-0.88 \\
\end{tabular} \\
\hline $\begin{array}{l}\text { Imp. } \\
\text { Healthfulness } \\
\text { (41) }\end{array}$ & $\begin{array}{l}2.5 \\
(.60)\end{array}$ & $\begin{array}{l}2.35 \\
(.65)\end{array}$ & -6.00 & $\begin{array}{l}2.81 \\
(.38)\end{array}$ & $\begin{array}{l}2.83 \\
(.38)\end{array}$ & 0.71 \\
\hline $\begin{array}{l}\text { Imp org/sust. } \\
\text { farming (41) }\end{array}$ & $\begin{array}{l}2.13 \\
(.87)\end{array}$ & $\begin{array}{l}2.09 \\
(.85)\end{array}$ & -1.88 & $\begin{array}{l}2.55 \\
(.63)\end{array}$ & $\begin{array}{l}2.50 \\
(.67)\end{array}$ & -1.96 \\
\hline $\begin{array}{l}\text { Imp. Locally } \\
\text { grown (41) }\end{array}$ & $\begin{array}{l}2.04 \\
(.71)\end{array}$ & $\begin{array}{l}2.09 \\
(.67)\end{array}$ & 2.45 & $\begin{array}{l}2.04 \\
(.71)\end{array}$ & $\begin{array}{l}2.55 \\
(.59)\end{array}$ & 6.25 \\
\hline $\begin{array}{l}\text { Imp. Shop } \\
\text { locally owned } \\
\text { (41) }\end{array}$ & $\begin{array}{l}1.74 \\
(.92)\end{array}$ & $\begin{array}{l}1.57 \\
(1.08)\end{array}$ & -9.77 & $\begin{array}{l}2.07 \\
(.86)\end{array}$ & $\begin{array}{l}2.33 \\
(.80)\end{array}$ & 12.56 \\
\hline $\begin{array}{l}\text { Imp. wages and } \\
\text { conditions ( } 41 \text { ) }\end{array}$ & $\begin{array}{l}1.18 \\
(.80)\end{array}$ & $\begin{array}{l}1.36 \\
(.85)\end{array}$ & 15.25 & $\begin{array}{l}2.05 \\
(.82)\end{array}$ & $\begin{array}{l}2.13 \\
(.80)\end{array}$ & 3.90 \\
\hline $\begin{array}{l}\text { Source other } \\
\text { garden (43) }\end{array}$ & $\begin{array}{l}0.73 \\
(.55) \\
\end{array}$ & $\begin{array}{l}.48 \\
(.51)\end{array}$ & -34.25 & $\begin{array}{l}0.85 \\
(.63)\end{array}$ & $\begin{array}{l}.03 \\
(.61)\end{array}$ & 21.18 \\
\hline $\begin{array}{l}\text { Source f- } \\
\text { stand/upick (43) }\end{array}$ & $\begin{array}{l}0.96 \\
(.21)\end{array}$ & $\begin{array}{l}.79 \\
(.42)\end{array}$ & -17.71 & $\begin{array}{l}0.95 \\
(.45)\end{array}$ & $\begin{array}{l}1.14 \\
(.68)\end{array}$ & 20.00 \\
\hline $\begin{array}{l}\text { Source discount } \\
\text { outlet (43) }\end{array}$ & $\begin{array}{l}0.09 \\
(.29)\end{array}$ & $\begin{array}{l}0 \\
(0)\end{array}$ & -100.00 & $\begin{array}{l}0.15 \\
(.27)\end{array}$ & $\begin{array}{l}.38 \\
(.89)\end{array}$ & 153.33 \\
\hline $\begin{array}{l}\text { Source gleaning } \\
\text { (43) }\end{array}$ & \begin{tabular}{|l|}
0 \\
$(0)$
\end{tabular} & $\begin{array}{l}0 \\
(0)\end{array}$ & 0 & $\begin{array}{l}0.12 \\
(.30)\end{array}$ & $\begin{array}{l}.26 \\
(.51)\end{array}$ & 116.7 \\
\hline
\end{tabular}

In summary, post-test scores reveal a significant difference between Forum participants and the control group on item 6, "hunger is a significant issue in our 
region," regardless of amount of Forum participation or work group participation. Forum participants also appear to differ from control group members with respect to their perceptions of school food, government policies, and interest in learning more. Differences identified between men and women are similar to those observed prior to the Forum.

\section{Change Scores}

Hypotheses Nine through Twelve examine differences in change scores between groups (Garson, n.d.). To understand the impact of the intervention one must look not only at post-test scores but some measure of change. Expecting the Forum group to evidence more change in scores, Hypothesis Nine tests for differences between the groups (i.e., $\mathrm{Ho}=$ no difference between Forum and non-Forum groups in the postsurvey). Hypothesis Ten explores whether difference scores vary depending upon amount of Forum participation (i.e., Ho = no difference by Forum participation all, most, and control). Hypothesis Eleven explores whether difference scores vary by work group participation (i.e., $\mathrm{Ho}=$ no difference between Forum attendees with work group participation, Forum attendees without work group participation, and control group). Hypothesis Twelve explores whether men and women evidence different amounts of change. 
Hypothesis 9:

Ho There is no difference between Forum and non-Forum groups in the amount of change between pre-survey and post-survey responses.

H1 There is a difference between Forum and non-Forum groups in the amount of change between pre-survey and post-survey responses.

Hypothesis Nine considers whether there is a significant difference between control and Forum groups in the amount of change between pre- and post-survey scores. Tests were performed using the absolute value of difference scores. Statistically significant differences were identified for three items:

- It's important that agriculture remains in our region (5).

- In the long run, we can't have a healthy economy without a healthy environment (33).

- Please rank how important each of the following is to you when making your food purchase decisions - no genetically engineered ingredients (41).

Both groups exhibited a decline in mean scores of agreement for item 5 , "it's important that agriculture remains in our region" $(6.88, .34$ to $6.62, .62$ for control and 6.84., 43 to $6.80, .41$ for Forum), though the mean change is larger for the control group than the Forum group (.50, s.d., .63 and .21 , s.d., .46). The control group 
evidenced a decrease in mean score for item 33, "in the long run, we can't have a healthy economy without a healthy environment" $(6.75, .58$ to $6.56, .81)$ while the Forum group evidenced an increase in mean score for this variable $(6.67, .72$ to 6.71 , $.61)$, with the mean change larger for the control group $(.75, .86)$ than the Forum group $(.33, .86)$. The control group evidenced a small decrease in mean score for item 41 (importance of no GE ingredients when making food purchase decisions) (2.44, 1.09 to $2.33, .90)$ while the mean score stayed the same on this variable for participants $(2.16,1.03$ and .97$)$. The mean change score was larger for the control group than the Forum group $(.63, .81$ and $.23, .43)$. One possible explanation for these differences is that Forum participation served as a mediating factor to impacts from exogenous events that lessened concern for some agriculture and environmental issues. Other explanations may be possible, or the results may be attributable to random error. 
Table 17: Hypothesis 9 Statistically Significant Findings

\begin{tabular}{|c|c|c|c|c|c|c|c|c|c|}
\hline & $\begin{array}{l}\text { Man } \\
\text { Whit }\end{array}$ & $\begin{array}{l}\text { Ind } \\
t\end{array}$ & $\begin{array}{l}\text { Phi } \\
\text { Cram } \\
\text { V }\end{array}$ & $\begin{array}{l}\text { Control } \\
\text { Mean } \\
\text { Amount } \\
\text { Change } \\
\end{array}$ & $\begin{array}{l}\text { Forum } \\
\text { Mean } \\
\text { Amount } \\
\text { Change }\end{array}$ & $\begin{array}{l}\text { C } \\
\text { Pre }\end{array}$ & $\begin{array}{l}\text { C } \\
\text { Post }\end{array}$ & $\begin{array}{l}\text { F } \\
\text { Pre }\end{array}$ & $\begin{array}{l}\text { F } \\
\text { Post }\end{array}$ \\
\hline $\begin{array}{l}\text { Ag in } \\
\text { region } \\
\text { (5) }\end{array}$ & .046 & .10 & $\mathrm{n} / \mathrm{a}$ & $\begin{array}{l}.50 \\
(.63)\end{array}$ & $\begin{array}{l}.21 \\
(.46)\end{array}$ & $\begin{array}{l}6.88 \\
(.34)\end{array}$ & $\begin{array}{l}6.62 \\
(.62)\end{array}$ & $\begin{array}{l}6.84 \\
(.43)\end{array}$ & $\begin{array}{l}6.80 \\
(.41)\end{array}$ \\
\hline $\begin{array}{l}\text { School } \\
\text { food } \\
\text { healthy } \\
\text { (29) }\end{array}$ & & .039 & $\mathrm{n} / \mathrm{a}$ & & & & & & \\
\hline $\begin{array}{l}\text { Econ } \\
\text { health } \\
\text { and env } \\
\text { (33) } \\
\end{array}$ & .038 & .025 & $\mathrm{n} / \mathbf{a}$ & $\begin{array}{l}75 \\
(.86)\end{array}$ & $\begin{array}{l}.33 \\
(.55)\end{array}$ & $\begin{array}{l}6.75 \\
(.58)\end{array}$ & $\begin{array}{l}6.56 \\
(.81)\end{array}$ & $\begin{array}{l}6.67 \\
(.72)\end{array}$ & $\begin{array}{l}6.71 \\
(.61)\end{array}$ \\
\hline $\begin{array}{l}\text { Region } \\
\text { losing } \\
\text { small } \\
\text { bus (18) } \\
\end{array}$ & & .020 & $\mathrm{n} / \mathrm{a}$ & & & & & & \\
\hline $\begin{array}{l}\text { Imp } \\
\text { conven. } \\
\text { (41) }\end{array}$ & & .009 & & 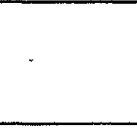 & & & & & \\
\hline $\begin{array}{l}\text { Imp no } \\
\mathrm{Ge}(41)\end{array}$ & $(.057)$ & .077 & .008 & $\begin{array}{l}.63 \\
(.81)\end{array}$ & $\begin{array}{l}.23 \\
(.43)\end{array}$ & $\begin{array}{l}2.44 \\
(1.09)\end{array}$ & $\begin{array}{l}2.33 \\
(.90)\end{array}$ & $\begin{array}{l}2.16 \\
(1.03) \\
\end{array}$ & $\begin{array}{l}2.16 \\
(.97)\end{array}$ \\
\hline
\end{tabular}

Hypothesis 10:

Ho There is no difference in the amount of change between pre-survey and postsurvey responses by Forum participation (all, most, control).

H1 There is a difference in the amount of change between pre-survey and post-survey responses by Forum participation (all, most, control).

Hypothesis Ten considers whether the amount of change in pre-survey and postsurvey scores varies by amount of Forum attendance. The omnibus tests indicate 
significant differences between groups for two items:

- Most people are knowledgeable about how their food choices impact the local economy and environment (16).

- In the long run, we can't have a healthy economy without a healthy environment (33).

Possible significant difference were identified for two items:

- Our current food system is socially just (2).

- Our government should ensure that businesses pay a living wage (37).

Post hocs failed to detect any between-group differences, however this finding may be attributable to random error or low power - particularly given that a difference between Forum and non-Forum attendees was identified in Hypothesis Nine for item 33 (In the long run, we can't have a healthy economy without a healthy environment). 
Table 18a: Hypothesis 10 Statistically Significant Findings

\begin{tabular}{|c|c|c|c|c|c|c|c|c|}
\hline & $\begin{array}{l}\text { Krusk } \\
\text { Wallis }\end{array}$ & Anova & $\begin{array}{l}\text { Levene } \\
\text { Statistic }\end{array}$ & Welch & $\begin{array}{l}\text { Brown } \\
\text { Forsythe }\end{array}$ & $\begin{array}{l}\text { Avg } \\
\text { Chan. } \\
\text { Mean } \\
\text { Cont. }\end{array}$ & $\begin{array}{l}\text { Avg } \\
\text { Chan. } \\
\text { Mean } \\
\text { Most }\end{array}$ & $\begin{array}{l}\text { Avg } \\
\text { Chan. } \\
\text { Mean } \\
\text { All }\end{array}$ \\
\hline $\begin{array}{l}\text { Socially } \\
\text { Just (2) }\end{array}$ & .038 & .026 & .012 & .045 & .058 & $\begin{array}{l}.68 \\
(.70)\end{array}$ & $\begin{array}{l}.64 \\
(.67)\end{array}$ & $\begin{array}{l}.24 \\
(.44)\end{array}$ \\
\hline \begin{tabular}{|l|} 
Know \\
Impact \\
$(16)$ \\
\end{tabular} & .030 & .027 & .000 & & & $\begin{array}{l}.06 \\
(.25)\end{array}$ & $\begin{array}{l}.37 \\
(.50)\end{array}$ & $\begin{array}{l}.07 \\
(.26)\end{array}$ \\
\hline $\begin{array}{l}\text { Econ } \\
\text { and Env } \\
(33)\end{array}$ & .041 & .033 & .057 & & & $\begin{array}{l}.75 \\
(.86)\end{array}$ & $\begin{array}{l}.37 \\
(.50)\end{array}$ & $\begin{array}{l}.23 \\
(.50)\end{array}$ \\
\hline \begin{tabular}{|l|} 
Gov \\
Living \\
Wage \\
$(37)$ \\
\end{tabular} & $(.057)$ & .047 & .622 & & & $\begin{array}{l}.38 \\
(.62)\end{array}$ & $\begin{array}{l}1.09 \\
(.94)\end{array}$ & $\begin{array}{l}.52 \\
(.74)\end{array}$ \\
\hline
\end{tabular}

Table 18b: Hypothesis 10 Statistically Significant Findings

\begin{tabular}{|l|l|l|l|l|l|l|}
\hline & $\begin{array}{l}\text { All } \\
\text { Pre }\end{array}$ & $\begin{array}{l}\text { All } \\
\text { Post }\end{array}$ & $\begin{array}{l}\text { Most } \\
\text { Pre }\end{array}$ & $\begin{array}{l}\text { Most } \\
\text { Post }\end{array}$ & $\begin{array}{l}\text { Control } \\
\text { Pre }\end{array}$ & $\begin{array}{l}\text { Control } \\
\text { Post }\end{array}$ \\
\hline $\begin{array}{l}\text { Socially Just } \\
(2)\end{array}$ & 1.63 & 1.70 & 2.27 & 2.27 & 1.88 & 2.13 \\
$(.85)$ & $(.75)$ & $(1.49)$ & $(1.49)$ & $(.96)$ & $(.81)$ \\
\hline Know & 1.70 & 1.59 & 1.91 & 2.27 & 1.75 & 1.94 \\
Impact (16) & $(.65)$ & $(.63)$ & $(.94)$ & $(1.35)$ & $(.93)$ & $(.93)$ \\
\hline Economy & 6.79 & 6.80 & 6.64 & 6.82 & 6.75 & 6.56 \\
and & $(.62)$ & $(.48)$ & $(.67)$ & $(.41)$ & $(.58)$ & $(.81)$ \\
Environment & & & & & & \\
(33) & & & & & & \\
\hline Gov Env & 6.07 & 6.03 & 6.09 & 5.73 & 6.06 & 6.06 \\
(36) & $(.83)$ & $(.94)$ & $(1.45)$ & $(.91)$ & $(1.12)$ & $(.93)$ \\
\hline
\end{tabular}


H11:

Ho There is no difference in the amount of change between pre-survey and postsurvey responses by work group participation (work group, non-work group, control). H1 There is a difference in the amount of change between pre-survey and post-survey responses by work group participation (work group, non-work group, control).

Hypothesis Eleven considers whether the amount of change in pre-survey and postsurvey scores varies by the amount of work group participation. A significant difference was detected for item 8 (In general, when I shop, prices for locally grown food are about the same as prices for non-locally grown food), and possibly for item 41 (importance of no GE ingredients when making food purchase decisions)). Post hocs identified significant difference for item 8 (local food costs the same as nonlocal) between Forum Yes Work Group and Forum No Work Group at .045 and between Forum Yes Work Group and control at .027. Mean change scores were 1.42, .60 , and .50 for Forum Yes Work Group, Forum No Work Group and control group, respectively. Mean scores increased from 3.83 to 5.08 for the Forum Yes Work Group and from 3.11 to 3.56 for the Forum No Work Group, and decreased from 4.31 to 3.69 for the control group. Thus, Forum Yes Work Group members and Forum No Work Group increased their agreement that local and non-local foods are similarly priced, while control group members decreased their agreement with this statement. As per the results for Hypotheses Three and Seven, it may be that the work group members 
were impacted differently and/or that the work group members had a fundamentally different perspective on this issue. There may also be low power or random error in the omnibus test. Post hocs did not identify significant differences between groups for item 41 (important no GE ingredients).

Table 19a: Hypothesis 11 Statistically Significant Findings

\begin{tabular}{|l|l|l|l|l|l|l|l|l|}
\hline & $\begin{array}{l}\text { Krusk } \\
\text { Wallis }\end{array}$ & Anova & $\begin{array}{l}\text { Levene } \\
\text { Statistic }\end{array}$ & Welch & $\begin{array}{l}\text { Brown- } \\
\text { Forsythe }\end{array}$ & $\begin{array}{l}\text { Avg } \\
\text { Chan. } \\
\text { Mean } \\
\text { F-WG }\end{array}$ & $\begin{array}{l}\text { Avg } \\
\text { Chan. } \\
\text { Mean } \\
\text { FNWG }\end{array}$ & $\begin{array}{l}\text { Avg. } \\
\text { Chan. } \\
\text { Mean } \\
\text { Control }\end{array}$ \\
\hline $\begin{array}{l}\text { Local } \\
\text { Same } \\
\text { Price (8) }\end{array}$ & .012 & .001 & .008 & .028 & .008 & $\begin{array}{l}1.42 \\
(1.0)\end{array}$ & $\begin{array}{l}.60 \\
.60)\end{array}$ & $\begin{array}{l}.50 \\
(.52)\end{array}$ \\
\hline $\begin{array}{l}\text { Imp NO } \\
\text { GE (41) }\end{array}$ & & .05 & .095 & & & $\begin{array}{l}.42 \\
(.51)\end{array}$ & $\begin{array}{l}.60 \\
(.88)\end{array}$ & $\begin{array}{l}.31 \\
(.48)\end{array}$ \\
\hline
\end{tabular}

Table 19b: Hypothesis 11 Statistically Significant Findings

\begin{tabular}{|l|l|l|l|l|l|l|}
\hline & $\begin{array}{l}\text { Mean } \\
\text { Forum } \\
\text { Work group } \\
\text { Pre }\end{array}$ & $\begin{array}{l}\text { Mean } \\
\text { Forum } \\
\text { Work group } \\
\text { Post }\end{array}$ & $\begin{array}{l}\text { Mean } \\
\text { Forum Non- } \\
\text { work group } \\
\text { Pre }\end{array}$ & $\begin{array}{l}\text { Mean } \\
\text { Forum Non- } \\
\text { work group } \\
\text { Post }\end{array}$ & $\begin{array}{l}\text { Mean } \\
\text { Control } \\
\text { Pre }\end{array}$ & $\begin{array}{l}\text { Mean } \\
\text { Control } \\
\text { Post }\end{array}$ \\
\hline $\begin{array}{l}\text { Local } \\
\text { Same } \\
\begin{array}{l}\text { Price } \\
(8)\end{array}\end{array}$ & 3.83 & $\begin{array}{l}5.08 \\
(1.53)\end{array}$ & $\begin{array}{l}3.11 \\
(1.45)\end{array}$ & $\begin{array}{l}3.56 \\
(1.44)\end{array}$ & $\begin{array}{l}(1.78) \\
\end{array}$ & $(1.08)$ \\
\hline
\end{tabular}




\section{$\mathrm{H} 12$}

Ho There is no difference in the amount of change between pre-survey and postsurvey responses by gender.

H1 There is a difference in the amount of change between pre-survey and post-survey responses by gender.

A significant difference between genders in the absolute value of change from presurvey to post-survey scores was identified for six items. These are:

- Our current school food programs are healthy for students (29).

- In the long run, we can't have a healthy economy without a healthy environment (33).

- It's okay to put restrictions on trade in order to protect human, environmental, or community health (38).

- Please rank how important each of the following is to you when making your food purchase decisions - healthfulness of product (41).

- Please rank how important each of the following is to you when making your food purchase decisions - price (41).

- Percent of your at home food groceries from the following source in a typical year - source foodbank (43).

Possible significant difference between genders in the absolute value of change from pre-survey to post-survey scores was identified for three other items (i.e., significant at 
.05 at one test, but not the other). These are:

- Please rank how important each of the following is to you when making your food purchase decisions - organic/sustainable farming methods (41).

- Please rank how important each of the following is to you when making your food purchase decisions - freshness of product (41).

- Percent of your at home food groceries from the following source in a typical year - source superstore (43).

Four of these nine items did not appear as significant on the pre- or post-survey analyses (H4, H8): It's okay to put restrictions on trade in order to protect human, environmental, or community health (38), importance of price to food purchase decisions (41), and source super store and food bank (43).

For the six significant items, men exhibited a greater amount of change for four items (two belief statements and two importance when shopping factors) and women exhibited a greater amount of change for two items (one belief statement and one source of food item). Disagreement that school food is healthy (29) decreased for men and increased for women ( 2.22 to 2.57 and 2.02 to 1.88 respectively). Agreement that a healthy economy is not feasible in the long run without a healthy environment (33) decreased for men and increased for women (6.61 to 6.39 and 6.73 to 6.83 , respectively). Agreement regarding restrictions on trade (38) increased for men and 
decreased for women (5.96 to 6.09 and 6.33 to 6.12 , respectively, with mean scores becoming more similar). The mean score for importance of healthfulness of product when purchasing (41) decreased for men while the mean score for this item increased for women ( 2.50 to 2.35 and 2.81 to 2.83 , respectively). The mean score for importance of price (41) decreased for men and increased for women (1.74 to 1.50 and 1.76 to 1.83 , respectively).

For the three possibly significant items, women exhibited a greater mean change on two items (importance when shopping factors) and men on one (source of food items), with "source superstore" increasing for women and decreasing for men and importance of freshness and importance of organic/sustainable farming methods (41) decreasing for women and increasing for men.

The meaning of these results is not clear. For example, it may be that the women held a stronger position against trade prior to the Forum and after participating in the Forum gained an appreciation for the role of trade in supporting the regional agriculture economy and, thus, lessened their support for trade restrictions. Or, it may be that men and women tended to participate in different open space groups, thus affecting the type and degree of change evidenced. Further, some of the results may be attributable to error. 
Table 20a: Hypothesis 12 Statistically Significant Findings

\begin{tabular}{|l|l|l|l|l|l|}
\hline & $\begin{array}{l}\text { Mann } \\
\text { Whitney }\end{array}$ & $\begin{array}{l}\text { Indepen. } \\
\mathrm{t}\end{array}$ & $\begin{array}{l}\text { Phi / } \\
\text { Cramer's } \\
\mathrm{V}\end{array}$ & $\begin{array}{l}\text { Male } \\
\text { Mean } \\
\text { Change } \\
\text { (S.D.) }\end{array}$ & $\begin{array}{l}\text { Female } \\
\text { Mean } \\
\text { Change } \\
\text { (S.D.) }\end{array}$ \\
\hline School food healthy (29) & .027 & .018 & $\mathrm{n} / \mathrm{a}$ & $.96(1.11)$ & $.44(.59)$ \\
\hline Long Run (33) & .006 & .015 & $\mathrm{n} / \mathrm{a}$ & $.74(.81)$ & $.26(.50)$ \\
\hline Ok Restrict Trade (38) & .012 & .020 & $\mathrm{n} / \mathrm{a}$ & $.65(.88)$ & $.17(.38)$ \\
\hline Imp Fresh (41) & 0 & .002 & & $.41(.50)$ & $.02(.16)$ \\
\hline Imp or/sust (41) & .009 & .008 & & $.64(.49)$ & $.29(.46)$ \\
\hline Imp healthful (41) & & & .000 & $.32(.48)$ & $.26(.45)$ \\
\hline Imp price & & & .008 & $.30(.47)$ & $.33(.47)$ \\
\hline Source superstore & & .039 & $\mathrm{n} / \mathrm{a}$ & $.24(.44)$ & $.65(.95)$ \\
\hline Source food bank (43) & .036 & .009 & $\mathrm{n} / \mathrm{a}$ & $.00(0)$ & $.24(.50)$ \\
\hline
\end{tabular}

Table 20b: Hypothesis 12 Statistically Significant Findings

\begin{tabular}{|c|c|c|c|c|c|c|c|c|}
\hline & $\begin{array}{l}\text { Male } \\
\text { Pre } \\
\text { Mean } \\
\text { Scores } \\
\text { (S.D.) }\end{array}$ & $\begin{array}{l}\text { Male } \\
\text { Post } \\
\text { Mean } \\
\text { Scores } \\
\text { (S.D.) }\end{array}$ & $\begin{array}{l}\% \\
\text { change }\end{array}$ & $\begin{array}{l}\text { Female } \\
\text { Pre } \\
\text { Mean } \\
\text { Scores } \\
\text { (S.D.) }\end{array}$ & $\begin{array}{l}\text { Female } \\
\text { Post } \\
\text { Mean } \\
\text { Scores } \\
\text { (S.D.) }\end{array}$ & $\begin{array}{l}\% \\
\text { change }\end{array}$ & $\begin{array}{l}\text { Male } \\
\text { Mean } \\
\text { Chan. } \\
\text { (S.D.) }\end{array}$ & $\begin{array}{l}\text { Female } \\
\text { Mean } \\
\text { Chan. } \\
\text { (S.D.) }\end{array}$ \\
\hline $\begin{array}{l}\text { School } \\
\text { food } \\
\text { healthy (29) }\end{array}$ & $\begin{array}{l}2.22 \\
(1.45)\end{array}$ & $\begin{array}{l}2.57 \\
(1.47)\end{array}$ & 15.77 & $\begin{array}{l}2.02 \\
(1.31)\end{array}$ & $\begin{array}{l}1.88 \\
(1.13)\end{array}$ & -6.93 & $\begin{array}{l}.96 \\
(1.11)\end{array}$ & $\begin{array}{l}.44 \\
(.59)\end{array}$ \\
\hline $\begin{array}{l}\text { Long } \\
\text { Run } \\
\text { (33) } \\
\end{array}$ & $\begin{array}{l}6.61 \\
(.78)\end{array}$ & $\begin{array}{l}6.39 \\
(.94)\end{array}$ & -3.33 & $\begin{array}{l}6.73 \\
(.63)\end{array}$ & $\begin{array}{l}6.83 \\
(.38)\end{array}$ & 1.49 & $\begin{array}{l}.74 \\
(.81)\end{array}$ & $\begin{array}{l}.26 \\
(.50)\end{array}$ \\
\hline $\begin{array}{l}\text { Ok Restrict } \\
\text { Trade } \\
(38) \\
\end{array}$ & $\begin{array}{l}5.96 \\
(1.02)\end{array}$ & $\begin{array}{l}6.09 \\
(.95)\end{array}$ & 2.18 & $\begin{array}{l}6.33 \\
(.86)\end{array}$ & $\begin{array}{l}6.12 \\
(.86)\end{array}$ & -3.32 & $\begin{array}{l}65 \\
(.88)\end{array}$ & $\begin{array}{l}.17 \\
(.38)\end{array}$ \\
\hline $\begin{array}{l}\text { Imp Fresh } \\
(41)\end{array}$ & $\begin{array}{l}2.74 \\
(.45)\end{array}$ & $\begin{array}{l}2.70 \\
(.47)\end{array}$ & -1.46 & $\begin{array}{l}2.90 \\
.30)\end{array}$ & $\begin{array}{l}2.74 \\
(.45)\end{array}$ & -5.52 & $\begin{array}{l}.41 \\
(.50)\end{array}$ & $\begin{array}{l}.02 \\
(.16)\end{array}$ \\
\hline $\begin{array}{l}\operatorname{Imp} \text { or/sus } \\
(41)\end{array}$ & $\begin{array}{l}2.13 \\
(.87)\end{array}$ & $\begin{array}{l}2.09 \\
(.85)\end{array}$ & -1.88 & $\begin{array}{l}2.55 \\
(.67)\end{array}$ & $\begin{array}{l}2.50 \\
(.67)\end{array}$ & -1.96 & $\begin{array}{l}.64 \\
(.49)\end{array}$ & $\begin{array}{l}.29 \\
(.46)\end{array}$ \\
\hline $\begin{array}{l}\text { Imp health } \\
(41)\end{array}$ & $\begin{array}{l}2.50 \\
(.60) \\
\end{array}$ & $\begin{array}{l}2.35 \\
(.65) \\
\end{array}$ & -6.00 & $\begin{array}{l}2.81 \\
(.40) \\
\end{array}$ & $\begin{array}{l}2.83 \\
(.38) \\
\end{array}$ & 0.71 & $\begin{array}{l}.32 \\
(.48) \\
\end{array}$ & $\begin{array}{l}.26 \\
(.45) \\
\end{array}$ \\
\hline $\begin{array}{l}\text { Imp. Price } \\
(41)\end{array}$ & $\begin{array}{l}1.74 \\
(.81)\end{array}$ & $\begin{array}{l}1.50 \\
(.96)\end{array}$ & -13.79 & $\begin{array}{l}1.76 \\
(.82)\end{array}$ & $\begin{array}{l}1.83 \\
(.74)\end{array}$ & 3.98 & $\begin{array}{l}.30 \\
(.47)\end{array}$ & $\begin{array}{l}.33 \\
(.47)\end{array}$ \\
\hline $\begin{array}{l}\text { Source super } \\
\text { store }\end{array}$ & $\begin{array}{l}1.18 \\
(.91)\end{array}$ & $\begin{array}{l}95 \\
(.87)\end{array}$ & -19.49 & $\begin{array}{l}1.1 \\
(1.00)\end{array}$ & $\begin{array}{l}1.14 \\
(1.02)\end{array}$ & 3.64 & $\begin{array}{l}24 \\
(.44)\end{array}$ & $\begin{array}{l}.65 \\
(.95)\end{array}$ \\
\hline $\begin{array}{l}\text { Source food } \\
\text { bank (43) }\end{array}$ & $\begin{array}{l}0 \\
(0)\end{array}$ & $\begin{array}{l}0 \\
(0) \\
\end{array}$ & & $\begin{array}{l}.02 \\
(.16) \\
\end{array}$ & $\begin{array}{l}.03 \\
(.17) \\
\end{array}$ & 50.00 & $\begin{array}{l}.00 \\
(0)\end{array}$ & $\begin{array}{l}.24 \\
(.50) \\
\end{array}$ \\
\hline
\end{tabular}


Summary Conclusions for Hypotheses 1 to 12

Little, if any, difference was detected between Forum and control groups on the pretest, including by amount of Forum participation and by work group participation. Significant differences were detected between men's and women's responses on the pre-test. While the direction and strength of the scores were similar, the detected differences seem to indicate that this population of women is slightly less sanguine about current food system conditions, have a slightly higher sense of social responsibility and food democracy, and care slightly more about health, organic and sustainable practices, locally grown, packaging, and wages and conditions when making food decisions. They are also more likely to secure food through a CSA and through gleaning.

Little difference was detected on the post-test between the Forum and control groups, including by amount of Forum participation and work group participation. The direction and strength of response remained similar, even where differences were detected (e.g., scores of 6.25 vs. 6.71). Most differences that were detected make sense given the content of the Forum (e.g., hunger received a fair amount of attention and there was a significant difference for the item "hunger is significant in this region") - the exception being the differences between work group participants regarding the price of locally grown and sustainable foods. As with the pre-survey, 
significant differences were detected between men's and women's responses, though, again, the direction and strength of the scores are similar. The detected differences seem to indicate that this population of women is slightly less sanguine about current food system conditions, have a slightly higher sense of social responsibility and food democracy, have a stronger sense of their knowledge and skills in making healthy food choices and appear to care slightly more about health, organic and sustainable practices, locally grown and owned, and wages and conditions when making purchase decisions. They are also more likely to secure food through others' gardens, farm stands and u-picks, discount outlets and gleaning. These results are consistent with literature identifying differences between women and men on a range of agroenvironmental beliefs and behaviors.

Little, if any, difference was detected between Forum and control groups in the analyses of absolute value of change between pre- and post-scores, including by amount of Forum participation and by work group participation. Some significant difference was detected between men's and women's change scores, though further analysis is necessary to discern why this may be the case. When examining results it is helpful to note that the amount of change is calculated irrespective of direction (i.e., absolute value); thus, mean scores may be the same for the pre- and post-survey even though the mean change is greater than zero (i.e., some people's score increased and some decreased, but the mean stayed the same). The fact that mean scores remain the 
same or similar, despite movement evidenced with change scores, suggests that the Forum helped to clarify opinions or values for participants rather than move or sway overall opinion in a particular direction.

There are some important caveats to be made regarding these findings. First, the identification of few significant findings from the pre- and post-survey may be in part due to low power, as discussed in Chapter Three. Second, validity and reliability may be compromised by respondents' assignation of differing meanings to the same question. For example, one respondent wrote comments in the margin that food is cheap and, thus, marked "strongly agree" that the current food system is socially just; respondents differently conceptualizing social justice (e.g., farmworkers, fair trade, family farm loss) may register disagreement that the food system is socially just, but for different reasons. Another respondent was conflicted as to whether the true cost of food should be reflected in price because s/he thought that to do so would mean that food would be unaffordable for many. Thus, while the survey was developed based on the literature, including similar surveys, and included a pilot test, inclusion of definitions might have enhanced results (though the increase in survey length may have negatively impacted response rate).

A third challenge relates to interpretation of results. For example, a respondent increased his/her agreement that the region is losing small businesses and increased 
agreement that small businesses are equally viable. Is this person confused or seeing a dual story - perhaps one where some small business are being "weeded" out but others can be viable. Similarly, noting whether the mean score for trade restriction increased or decreased after the Forum does not yield understanding of how and why this support changed, nor the meaning of the change. For example, some respondents may have increased their appreciation of many Northwest farmers' reliance on export markets and decreased their support for trade restrictions (without necessarily lessoning their concern for impacts of trade), while others may have increased their appreciation of some of the negative consequences of global trade agreements and increased their support for trade restrictions.

Another measurement challenge relates to the way results sometimes seem to differ depending upon the question and/or methods used. For example, one interviewee noted that she is "far more attentive" to local purchases and has shifted her purchase habits, including a willingness to pay a premium for local, yet on the pre- and postsurvey her response to "importance of locally grown" remained "fairly" important (2 on scale 0 to 3 ) and locally owned "little" important ( 1 on scale 0 to 3 ). Thus, the interview revealed an understanding of impact that was not captured by the survey instrument. Another interviewee said that she goes to New Seasons Market (a locally owned store) whenever possible because of what she has learned through CFM, but her score on the survey regarding importance of shop being locally owned stayed the 
same ("fairly" or 2 on a scale of 0 to 3 ). Is her reported behavior shift more about the relationship she now feels having met the market owner than that it is about caring for local ownership? Or could it be that her support for locally grown is the driver ("extremely" 3 on a 0 to 3 scale) and she knows now that this store carries a lot of locally grown produce. These challenges affirm the benefits of triangulating evidence to gain a deeper and more accurate understanding of the process and its effects.

\section{$\underline{\text { Factor and Cluster Analysis }}$}

Q Factor Analysis and Cluster Analysis were conducted to explore whether the case study population includes sub-groups of people with similar orientations or viewpoints and, if so, whether group membership and/or salience changed after the April Forum.

\section{Q Factor Analysis}

Two to four components are defined for the pre-survey and two to three components are defined for the post-survey using standard methods for determining the number of factors as described in Chapter Three (i.e., Kaiser rule of eigenvalues greater than or equal to one, the Cattel scree plot test, and the percent of variance criterion). In this case, the rotated pre-survey solution is characterized by a high degree of mixed or 
multiple loadings, indicating that a single dominant factor (substantial consensus among respondents) may exist (Brown, 2006). In such situations an unrotated solution may be preferred (Brown, 2006). The initial (unrotated) and rotated component matrices are provided in Appendix $\mathrm{N}$.

Table 21: Pre Eigenvalues and Percent Variance Explained

\begin{tabular}{|l|l|l|l|l|l|l|}
\hline \multicolumn{3}{|c|}{ Unrotated } & \multicolumn{3}{c|}{ Rotated } \\
\hline & $\begin{array}{l}\text { Total } \\
\text { (Eigen } \\
\text { values) }\end{array}$ & $\begin{array}{l}\% \text { of } \\
\text { Variance }\end{array}$ & $\begin{array}{l}\text { Cumulative } \\
\%\end{array}$ & $\begin{array}{l}\text { Total } \\
\text { (Eigen } \\
\text { values) }\end{array}$ & $\begin{array}{l}\text { \% of } \\
\text { Variance }\end{array}$ & Cumulative \% \\
\hline 1 & 40.280 & 82.205 & 82.205 & 17.070 & 34.836 & 34.836 \\
\hline 2 & 2.095 & 4.276 & 86.480 & 15.723 & 32.087 & 66.923 \\
\hline 3 & 1.376 & 2.809 & 89.289 & 7.132 & 14.556 & 81.479 \\
\hline 4 & 1.042 & 2.127 & 91.416 & 4.869 & 9.937 & 91.416 \\
\hline
\end{tabular}

Table 22: Post Eigenvalues and Percent Variance Explained

\begin{tabular}{|l|l|l|l|l|l|l|}
\hline \multicolumn{3}{|c|}{ Unrotated } & \multicolumn{3}{c|}{ Rotated } \\
\hline & $\begin{array}{l}\text { Total } \\
\text { (Eigen } \\
\text { values) }\end{array}$ & $\begin{array}{l}\% \text { of } \\
\text { Variance }\end{array}$ & $\begin{array}{l}\text { Cumulative } \\
\%\end{array}$ & $\begin{array}{l}\text { Total } \\
\text { (Eigen } \\
\text { values) }\end{array}$ & $\begin{array}{l}\text { \% of } \\
\text { Variance }\end{array}$ & Cumulative \% \\
\hline 1 & 41.109 & 83.896 & 83.896 & 31.686 & 64.666 & 64.666 \\
\hline 2 & 2.289 & 4.672 & 88.568 & 8.876 & 18.114 & 82.780 \\
\hline 3 & 1.142 & 2.331 & 90.899 & 3.978 & 8.118 & 90.899 \\
\hline
\end{tabular}

On the unrotated pre-survey solution forty-four (of forty-nine) cases load on

Component One only (and at .80 or greater). Four cases load on Components One and Two at .50 or greater (defined as Component Two in Table 25). One case loads on Components One and Three at .50 or greater (defined as an outlier, not included in Table 25). On the rotated pre-survey solution, factor membership was compared at the 
.50 and .60 loading thresholds (i.e., for the .50 scenario allocations were made if a case loaded on one and only one component at .50 or greater; likewise for the .60 scenario.). This allocation method facilitates "purity" of viewpoint, ensuring that the component is as unambiguous as possible: Average component scores are calculated with cases that load on that component and no other. ${ }^{6}$ Twenty-five of forty-nine cases $(51 \%)$ load on more than one factor at .50 or greater. Structure ${ }^{7}$ improves using a .60 threshold; only three cases load on more than one component (although another four are close with .59 scores). For the pre-survey, the .50 threshold yields eleven members for Component One, eight members for Component Two, three members for Component Three, and one outlier (Component Four which is not considered). The .60 threshold yields twenty-three members for Component One, fifteen for Component Two, four for Component Three, and two for Component Four, though with a number of cases close to multiple loading (e.g., .536 and .611 or .599 and .686). Membership between thresholds is similar: at .60 , Component One retains all eleven .50 loaders (and adds twelve others); Component Two retains all eight .50 loaders (and adds seven others); Component Three retains all three .50 loaders (and adds one other). Component membership under the three scenarios is summarized in Table 23.

\footnotetext{
${ }^{6}$ This is the average survey item score for all members of the component. For example, a component with three cases or members whose scores were 2,3 , and 3 on question one would have an average component score of 2.33 for that question.

${ }^{7}$ Simple structure is the condition of each variable loading "heavily" on just one factor (Garson, n.d.).
} 
Table 23: Component Members Under Three Scenarios for Pre-Survey

\begin{tabular}{|l|l|l|l|l|l|l|}
\hline & $\begin{array}{l}\text { Component } \\
1\end{array}$ & $\begin{array}{l}\text { Component } \\
2\end{array}$ & $\begin{array}{l}\text { Component } \\
3\end{array}$ & $\begin{array}{l}\text { Component } \\
4\end{array}$ & $\begin{array}{l}\text { Multiple } \\
\text { Loaders }\end{array}$ & $\begin{array}{l}\text { Non } \\
\text { Loaders }\end{array}$ \\
\hline Unrotated & 44 & & & 3 & 5 & \\
\hline $\begin{array}{l}\text { Rotated .50 } \\
\text { Threshold }\end{array}$ & 11 & 8 & 3 & 1 & $\begin{array}{l}2 \\
5\end{array}$ & \\
\hline $\begin{array}{l}\text { Rotated } .60 \\
\text { Threshold }\end{array}$ & 23 & 15 & 4 & 2 & 3 & 2 \\
\hline
\end{tabular}

On the unrotated post-survey matrix, most individuals (forty-three of forty-nine) load on Component One only (at .80 or greater); one loads on Component Two, one loads on Components Two and Three, and four load on Components One and Two (defined as Component Two in Table 26). On the rotated solution, analysis was again conducted at the .50 and .60 loading thresholds. Six of forty-nine cases (12\%) load on more than one component at .50 or greater; zero cases load on more than one component using a .60 threshold (with one no loader). For the post-survey rotated solution, the .50 threshold yields thirty-seven members for Component One, three for Component Two and three for Component Three. The .60 threshold yields forty-three members for Component One, three members for Component Two, and two members for Component Three. Membership between the .50 and .60 thresholds is similar, with Component One retaining its thirty-seven .50 members and adding six more at .60 , Component Two retaining the same three members, and Component Three retaining two .50 members and seeing one become a non-loader. The scenarios (unrotated, rotated .50 , rotated .60 ) yield a two or three component solution for the post-survey with the vast majority of respondents loading on Component One. Component 
membership under the three scenarios is summarized in Table 24.

Table 24: Component Members Under Three Scenarios for Post-Survey

\begin{tabular}{|l|l|l|l|l|l|}
\hline & $\begin{array}{l}\text { Component } \\
1\end{array}$ & $\begin{array}{l}\text { Component } \\
2\end{array}$ & $\begin{array}{l}\text { Component } \\
3\end{array}$ & $\begin{array}{l}\text { Multiple } \\
\text { Loaders }\end{array}$ & $\begin{array}{l}\text { Non } \\
\text { Loaders }\end{array}$ \\
\hline Unrotated & 43 & 1 & & 5 & \\
\hline $\begin{array}{l}\text { Rotated } .50 \\
\text { Threshold }\end{array}$ & 37 & 3 & 3 & 6 & \\
\hline $\begin{array}{l}\text { Rotated .60 } \\
\text { Threshold }\end{array}$ & 43 & 3 & 2 & & 1 \\
\hline
\end{tabular}

Factor scores provide the basis for interpretation in Q-factor analysis (Brown, 1980).

For each component, an average score is calculated for each of the forty Likert

statements (questions 1 to 40 on the pre-post survey). In order to ensure robustness of results, average scores under various loading (membership) scenarios were calculated (Tables 25 and 26). For the pre-survey, Component Two for the unrotated solution is comprised of the four individuals that loaded on Components One and Two at the greater than .50 threshold. Three components (rather than four) were used for the .50 and .60 scenarios given the size of the component (one or two members) and the fact that in the .60 scenario the two have divergent scores on a number of items and almost load on different components. For the post-survey, two components were calculated for the unrotated solution, with Component Two comprised of the four individuals who loaded on Components One and Two.

Differences of approximately two or greater were considered to be "significant" in 
identify distinguishing statements, subject to interpreter discretion (Brown, 1980, 1993). ${ }^{8}$ For the pre-survey, distinguishing statements on all three scenarios (rotated .50 threshold, rotated .60 threshold, and unrotated) include:

- The benefits of globalization outweigh the costs (12).

- Genetically engineered (genetically modified) foods should not be allowed (26).

- It would be risky or dangerous to be dependent on non-local, imported food (34).

Statements that distinguish less strongly (e.g., two points different on some but not all scenarios or slightly less than two across all scenarios) include:

- Our current food system is socially just (2).

- In general, when I shop, prices for locally grown food are about the same as prices for non-locally grown food (8).

- Small, local businesses and national corporations are equally viable in our current food system (10).

- Our region is losing small, locally owned businesses (18).

\footnotetext{
${ }^{8}$ The top ten agree/disagree statement method employed by Pelletier et al. (1999b) was not used because the number of ties confounded results, producing items that appeared on both top ten agree and top ten disagree lists. Other questions related to the research include the use of forced sorts (something common but debated in Q Factor Analysis), "complex" statements embedding multiply concepts in Q statements, and a lack of detail regarding loading.
} 
- The current food system does a good job of maintaining biological diversity (20).

- The current food system does a good job of maintaining cultural traditions and heritage (21).

- Most farm workers have decent living condition (28).

- Our current school food programs are healthy for students (29).

- Our current school food programs support local environmental and economic health (30).

- We are too dependent on non-local sources of food (31).

- It's okay to put restrictions on trade in order to protect human, environmental, or community health (38).

Examining the scores for these statements, Component Three (Two on the unrotated scenario) presents a viewpoint that holds more confidence in the current food system's performance with respect to a range of bio-cultural factors, and more neo-liberal attitudes with respect to trade and government intervention. Components One and Two are very similar for the rotated scenarios, with the main distinguishing statement referring to the price equivalence of locally grown products. Thus, two main viewpoints are identified, consistent with the two components defined with the unrotated solution. 
Table 25: Pre-Survey Average Scores Loading Scenarios

\begin{tabular}{|l|c|c|c|c|c|c|c|c|}
\hline \multicolumn{2}{|c|}{ Unrotated } & \multicolumn{3}{c|}{ Rotated .50< } & \multicolumn{3}{c|}{ Rotated .60< } \\
\hline $\begin{array}{l}\text { Component } \\
\text { Numbers }\end{array}$ & 1 & 2 & 1 & 2 & 3 & 1 & 2 & 3 \\
\hline $\begin{array}{l}\text { Number of } \\
\text { Members }\end{array}$ & 44 & 4 & 11 & 8 & 3 & 23 & 15 & 4 \\
\hline Questions & & & & & & & & \\
\hline 1 & 1.67 & 3.25 & 2.00 & 2.00 & 2.67 & 1.64 & 1.63 & 2.67 \\
\hline 2 & 1.64 & 4.00 & 1.82 & 1.88 & 3.00 & 1.57 & 1.63 & 3.25 \\
\hline 3 & 1.84 & 3.25 & 1.82 & 2.00 & 2.33 & 1.83 & 1.75 & 3.33 \\
\hline 4 & 5.89 & 5.00 & 5.27 & 6.13 & 5.00 & 5.70 & 6.13 & 5.00 \\
\hline 5 & 6.86 & 6.50 & 7.00 & 6.75 & 6.33 & 6.91 & 6.81 & 6.25 \\
\hline 6 & 6.64 & 6.50 & 6.45 & 6.50 & 6.33 & 6.74 & 6.63 & 6.25 \\
\hline 7 & 6.50 & 6.75 & 6.45 & 6.13 & 6.67 & 6.65 & 6.44 & 6.75 \\
\hline 8 & 3.23 & 3.50 & 2.09 & 5.25 & 3.00 & 2.13 & 4.94 & 3.50 \\
\hline 9 & 2.21 & 2.25 & 2.00 & 2.38 & 2.33 & 2.04 & 2.60 & 2.25 \\
\hline 10 & 1.86 & 3.25 & 2.45 & 1.63 & 3.00 & 2.17 & 1.50 & 3.25 \\
\hline 11 & 6.77 & 5.75 & 6.64 & 6.63 & 6.33 & 6.74 & 6.81 & 6.00 \\
\hline 12 & 2.11 & 4.75 & 2.91 & 1.88 & 4.00 & 2.13 & 1.94 & 4.75 \\
\hline 13 & 2.32 & 1.75 & 2.27 & 3.13 & 1.67 & 2.22 & 2.63 & 2.00 \\
\hline 14 & 6.32 & 6.75 & 6.18 & 6.50 & 6.67 & 6.17 & 6.38 & 6.75 \\
\hline 15 & 6.09 & 4.25 & 5.82 & 6.00 & 6.33 & 6.09 & 6.06 & 5.25 \\
\hline 16 & 1.68 & 2.25 & 1.64 & 1.88 & 1.67 & 1.57 & 1.81 & 2.50 \\
\hline 17 & 6.80 & 6.50 & 6.64 & 6.63 & 6.67 & 6.83 & 6.69 & 6.50 \\
\hline 18 & 6.16 & 4.50 & 6.55 & 5.75 & 3.33 & 6.39 & 6.06 & 4.75 \\
\hline 19 & 6.73 & 6.00 & 6.45 & 6.75 & 6.67 & 6.78 & 6.81 & 6.25 \\
\hline 20 & 1.57 & 3.75 & 2.09 & 1.75 & 3.00 & 1.73 & 1.50 & 4.33 \\
\hline 21 & 1.88 & 3.75 & 2.27 & 2.00 & 3.67 & 2.00 & 1.81 & 4.00 \\
\hline 22 & 6.14 & 4.50 & 6.09 & 5.88 & 6.00 & 6.55 & 5.53 & 5.50 \\
\hline
\end{tabular}




\begin{tabular}{|l|l|l|l|l|l|l|l|l|}
\hline 23 & 1.51 & 2.50 & 1.73 & 2.25 & 2.00 & 1.45 & 1.69 & 2.25 \\
\hline 24 & 6.67 & 5.25 & 6.55 & 6.63 & 5.67 & 6.64 & 6.69 & 5.50 \\
\hline 25 & 6.65 & 4.00 & 6.18 & 7.00 & 5.33 & 6.41 & 6.94 & 4.25 \\
\hline 26 & 5.23 & 1.50 & 4.27 & 5.75 & 3.33 & 4.82 & 5.75 & 2.25 \\
\hline 27 & 1.86 & 2.75 & 1.91 & 2.63 & 2.67 & 1.57 & 2.06 & 3.75 \\
\hline 28 & 2.09 & 3.25 & 2.09 & 2.63 & 4.33 & 1.91 & 2.25 & 3.75 \\
\hline 29 & 1.91 & 3.25 & 1.64 & 2.25 & 2.67 & 1.68 & 2.38 & 3.50 \\
\hline 30 & 1.58 & 2.75 & 1.73 & 1.75 & 3.00 & 1.55 & 1.56 & 3.25 \\
\hline 31 & 6.51 & 4.00 & 6.64 & 6.25 & 5.33 & 6.68 & 6.38 & 4.25 \\
\hline 32 & 6.93 & 6.25 & 7.00 & 6.88 & 6.67 & 6.91 & 6.94 & 6.50 \\
\hline 33 & 6.74 & 5.75 & 6.64 & 6.63 & 6.67 & 6.68 & 6.81 & 6.25 \\
\hline 34 & 6.25 & 3.00 & 6.18 & 6.25 & 3.67 & 6.30 & 6.31 & 2.75 \\
\hline 35 & 6.38 & 4.75 & 5.50 & 6.38 & 6.00 & 6.32 & 6.47 & 5.00 \\
\hline 36 & 6.07 & 5.25 & 5.73 & 6.00 & 6.00 & 6.17 & 5.87 & 5.50 \\
\hline 37 & 5.95 & 4.25 & 5.09 & 5.75 & 5.00 & 5.96 & 5.93 & 4.75 \\
\hline 38 & 6.26 & 4.75 & 6.27 & 6.38 & 4.67 & 6.35 & 6.20 & 5.00 \\
\hline 39 & 6.77 & 5.50 & 6.64 & 6.63 & 6.33 & 6.74 & 6.75 & 5.33 \\
\hline 40 & 6.64 & 6.00 & 6.27 & 6.63 & 6.33 & 6.57 & 6.67 & 6.00 \\
\hline
\end{tabular}

For the post-survey, distinguishing statements on the $.50, .60$, and unrotated scenarios include:

- The benefits of globalization outweigh the costs (12).

- Our government should ensure that all people get enough to eat (22).

- Genetically engineered (genetically modified) foods should be labeled (25).

- Genetically engineered (genetically modified) foods should not be allowed (26).

- We are too dependent on non-local sources of food (31).

- It would be risky or dangerous to be dependent on non-local, imported food (34).

- Our government should ensure that businesses pay a living wage (37). 
Statements that distinguish less strongly (e.g., two points different on some but not all scenarios or slightly less than two across all scenarios) include:

- Our current food system is ecologically sound (1).

- Our current food system is socially just (2).

- Our current food system promotes community health (3).

- In general, when I shop, prices for locally grown food are about the same as prices for non-locally grown food (8).

- My food choices make a difference to the local economy (15).

- Access to food is a basic human right (19).

- The current food system does a good job of maintaining biological diversity (20).

- The current food system does a good job of maintaining cultural traditions and heritage (21).

- In general, food prices reflect full production and distribution costs, including impacts to environmental and human health (23).

- Most farm workers are paid a living wage (27).

- Most farm workers have decent living conditions (28).

- Our current school food programs are healthy for students (29).

- In the long run, we can't have a healthy economy without a healthy environment (33). 
- The price of food should reflect its real costs to the environment and human health (35).

- There should be a vision and strategy to ensure that we have a sustainable food system in our region (39).

- I want to learn more about how food systems - from field to fork - affect economic, environmental, and human health in our community (40).

Overall, Component Three (Two on the unrotated scenario) presents a more neoliberal viewpoint with respect to trade, government intervention, and food access. This group also identifies less confidence that their choices make a difference to the local economy. Members of Component One, the majority viewpoint, have less confidence about the health and viability of the current food system's performance with respect to a range of bio-cultural factors, believe we are too dependent on nonlocal food and that it is risky to be dependent, and believe GE foods should not be allowed and should be labeled. Unlike the pre-survey results, a third viewpoint is identified for the rotated scenarios, though membership in Components Two and Three is small. Component Two is distinguished by more "middle of the road" or ambiguous responses with respect to the role of government, amount of dependence on non-local food, risk associated with dependence on non-local food, and conditions for farm workers. 
Table 26: Post-Survey Average Scores Loading Scenarios

\begin{tabular}{|l|l|l|l|l|l|l|l|l|}
\hline \multicolumn{2}{|c|}{ Unrotated } & \multicolumn{3}{c|}{ Rotated .50< } & \multicolumn{3}{c|}{ Rotated .60< } \\
\hline & & & & & & & & \\
\hline $\begin{array}{l}\text { Component } \\
\text { Numbers }\end{array}$ & 1 & 2 & 1 & 2 & 3 & 1 & 2 & 3 \\
\hline $\begin{array}{l}\text { Number of } \\
\text { Members }\end{array}$ & 43 & 4 & 37 & 3 & 3 & 43 & 3 & 2 \\
\hline Questions & & & & & & & & \\
\hline 1 & 1.86 & 2.25 & 1.89 & 1.67 & 4.67 & 1.86 & 1.67 & 5.00 \\
\hline 2 & 1.77 & 2.75 & 1.79 & 2.33 & 3.33 & 1.77 & 2.33 & 3.00 \\
\hline 3 & 2.00 & 2.00 & 2.03 & 1.67 & 4.33 & 2.00 & 1.67 & 5.00 \\
\hline 4 & 5.95 & 5.25 & 5.92 & 5.00 & 6.00 & 5.95 & 5.00 & 6.00 \\
\hline 5 & 6.88 & 6.25 & 6.89 & 6.33 & 6.00 & 6.88 & 6.33 & 6.00 \\
\hline 6 & 6.86 & 6.00 & 6.84 & 6.00 & 6.67 & 6.86 & 6.00 & 7.00 \\
\hline 7 & 6.60 & 6.50 & 6.59 & 6.33 & 6.33 & 6.60 & 6.33 & 6.00 \\
\hline 8 & 3.95 & 3.50 & 3.89 & 2.67 & 5.00 & 3.95 & 2.67 & 4.50 \\
\hline 9 & 2.69 & 2.50 & 2.59 & 2.33 & 2.33 & 2.69 & 2.33 & 2.00 \\
\hline 10 & 1.95 & 3.00 & 1.86 & 3.33 & 2.33 & 1.95 & 3.33 & 2.50 \\
\hline 11 & 6.74 & 6.50 & 6.73 & 6.67 & 6.33 & 6.74 & 6.67 & 6.50 \\
\hline 12 & 2.19 & 4.25 & 2.19 & 3.67 & 5.67 & 2.19 & 3.67 & 5.50 \\
\hline 13 & 2.17 & 2.75 & 2.08 & 3.00 & 3.33 & 2.17 & 3.00 & 4.00 \\
\hline 14 & 6.50 & 6.50 & 6.46 & 6.33 & 7.00 & 6.50 & 6.33 & 7.00 \\
\hline 15 & 6.33 & 5.50 & 6.38 & 6.33 & 3.33 & 6.33 & 6.33 & 3.50 \\
\hline 16 & 1.74 & 1.75 & 1.78 & 1.67 & 2.33 & 1.74 & 1.67 & 2.50 \\
\hline 17 & 6.76 & 6.50 & 6.78 & 6.33 & 6.33 & 6.76 & 6.33 & 6.00 \\
\hline 18 & 6.21 & 6.25 & 6.24 & 6.33 & 5.33 & 6.21 & 6.33 & 5.00 \\
\hline 19 & 6.88 & 6.75 & 6.86 & 7.00 & 4.67 & 6.88 & 7.00 & 4.00 \\
\hline 20 & 1.58 & 3.00 & 1.55 & 3.00 & 3.33 & 1.58 & 3.00 & 3.50 \\
\hline 21 & 1.65 & 2.75 & 1.68 & 3.00 & 3.33 & 1.65 & 3.00 & 4.00 \\
\hline 22 & 6.33 & 4.75 & 6.29 & 4.33 & 3.67 & 6.33 & 4.33 & 2.50 \\
\hline 23 & 1.40 & 2.75 & 1.26 & 3.33 & 1.67 & 1.40 & 3.33 & 2.00 \\
\hline 24 & 6.63 & 5.00 & 6.71 & 4.67 & 5.33 & 6.63 & 4.67 & 5.00 \\
\hline 25 & 6.79 & 3.25 & 6.89 & 3.00 & 3.67 & 6.79 & 3.00 & 3.50 \\
\hline 26 & 5.14 & 2.00 & 5.34 & 1.67 & 2.00 & 5.14 & 1.67 & 1.50 \\
\hline 27 & 1.63 & 3.25 & 1.63 & 3.00 & 2.33 & 1.63 & 3.00 & 1.50 \\
\hline 28 & 1.93 & 3.75 & 1.84 & 3.67 & 3.00 & 1.93 & 3.67 & 2.50 \\
\hline 29 & 1.88 & 2.25 & 1.82 & 2.33 & 3.33 & 1.88 & 2.33 & 4.00 \\
\hline 30 & 1.63 & 2.00 & 1.66 & 2.00 & 2.33 & 1.63 & 2.00 & 2.50 \\
\hline 31 & 6.58 & 3.75 & 6.55 & 4.33 & 2.33 & 6.58 & 4.33 & 2.50 \\
\hline 33 & 6.93 & 6.50 & 6.92 & 6.33 & 6.33 & 6.93 & 6.33 & 6.00 \\
\hline & 6.88 & 6.00 & 6.89 & 6.00 & 5.00 & 6.88 & 6.00 & 4.50 \\
\hline
\end{tabular}




\begin{tabular}{|l|l|l|l|l|l|l|l|l|}
\hline 34 & 6.47 & 3.75 & 6.50 & 4.00 & 2.33 & 6.47 & 4.00 & 2.00 \\
\hline 35 & 6.30 & 5.00 & 6.26 & 5.00 & 4.33 & 6.30 & 5.00 & 4.00 \\
\hline 36 & 6.05 & 5.00 & 6.03 & 5.33 & 5.00 & 6.05 & 5.33 & 5.50 \\
\hline 37 & 6.10 & 4.00 & 6.08 & 4.00 & 2.67 & 6.10 & 4.00 & 2.00 \\
\hline 38 & 6.33 & 5.25 & 6.34 & 5.67 & 4.67 & 6.33 & 5.67 & 5.00 \\
\hline 39 & 6.74 & 5.75 & 6.74 & 6.00 & 4.67 & 6.74 & 6.00 & 4.50 \\
\hline 40 & 6.48 & 4.75 & 6.46 & 5.33 & 4.67 & 6.48 & 5.33 & 5.50 \\
\hline
\end{tabular}

A relatively stable dominant viewpoint and minority viewpoint is identified in the preand post-survey analyses. A second minority viewpoint is identified in the postsurvey analysis that indicates a potential moderating of viewpoint for a few participants.

Component membership also appears rather stable over time. Working with the less ambiguous unrotated solution, ${ }^{9}$ most respondents load on Component One on the preand post-survey. Of the four respondents loading on the minority view on the presurvey, two become members of Component Two on the post-survey. Both strengthened concern for environmental and social justice issues. One increased agreement that the benefits of globalization outweigh the costs while one decreased agreement. The other two members of the pre-survey minority viewpoint remain minority viewpoint members on the post-survey. One reduced concerns about some bio-cultural issues and increased his/her sense that personal choices impact the local economy; the other increased concerns about some bio-cultural dimensions of the

\footnotetext{
${ }^{9}$ Results are comparable with the rotated solutions, though more ambiguous due to multiple loadings, again indicating high congruence among respondents.
} 
current food system, while also increasing support for government intervention though decreasing support for trade restrictions. The other two individuals that joined Component Two loaded on Component One in the pre-survey (though one almost loaded on the minority view on the pre-survey). Both reduced concerns about some aspects of the current food system and support for some government interventions; one increased his/her sense of personal choices impacting the local economy and the other reduced that sense.

As with the hypothesis testing, a limit of this data is potentially different assignation of meaning to statements (i.e., it is possible for people to respond to statements similarly and mean different things). Additionally, there may be random error (e.g., respondent accidentally marking the wrong scale measure or answering slightly differently on a given day).

Although conclusions regarding viewpoint and membership stability are clouded by ambiguities in component definition (i.e., multiple loadings) and variation in membership under differing loading thresholds, clear themes do emerge. Overall, it appears that the respondents represent a rather homogeneous population. A dominant viewpoint was identified and remained stable over time. Viewpoint membership also remained rather stable over time. Further, strengthened loads and reduction of multiple loadings indicate a lessening of ambiguity or clarification of beliefs over 
time.

Contrary to findings by Pelletier et al. (1999b) identification with social and environmental justice viewpoints did not appear to decrease in this case. Further, where strength of agreement regarding social justice or environmental issues does decrease it usually does so with respect to questions related to current conditions rather than beliefs about whether the issue is important (e.g., the current system is ecologically sound). Thus, a decrease on environmental or social justice items may represent a change in understanding of an issue rather than a change in beliefs or issue salience. It is not possible to tell from the data whether such shifts represent the development of a more informed perspective on an issue influence of "greenwashing" or hegemonic discourse (e.g., respondent concern about an issue decreased but the situation actually is not as rosy as the respondent was led to believe).

\section{Cluster Analysis}

As detailed in Chapter Three, cluster analysis was also performed in order to determine whether discrete viewpoints may exist and, if so, whether viewpoints changed with Forum participation. 
The pre-survey data yields two to five groups depending upon which test is used and interpretation of the clusters. The Ward ${ }^{10}$ and Furthest Neighbor (Complete Linkage) tests provide the clearest results: most of the other results are "stringy" and many have large distances on the far branches indicating that the groups are not distinct (Stockburger, 1998). On all nine tests, there are four people that consistently cluster together at one end, though here, too, the branches are often long. These are individuals that load on the minority view (Group Three) on the pre-survey factor analysis at .50 or .60 .

Two to five groups also appear with the post-test data. Again, the Ward and Furthest Neighbor (Complete Linkage) tests provide the clearest results and distances on many of the tests are rather large, suggesting that the "grouping" is not very effective. Here, too, there are four people that consistently cluster together on one end, though sometimes with long branches. Three of these four people are members of the "minority" component on the post-survey factor analysis (Group Three); one is a member of the minority viewpoint on the pre-survey factor analysis and the "middle" viewpoint (Group Two) on the post-survey factor analysis.

Overall, the cluster analysis indicates that there is a majority group though one that is not unambiguous (i.e., branches are long), and a few cases that differ to a moderate

\footnotetext{
${ }^{10}$ Bacher (2002) suggests Ward for data that can be treated as interval (pp. 54-55).
} 
degree from the others, though also not representing an unambiguous "viewpoint." These findings are consistent with the Q factor analysis findings that identified two to four components, a majority viewpoint accounting for most cases, and rather stable group membership between the pre- and post-survey.

\section{$\underline{\text { Summary }}$}

Results from the statistical examination of belief and behavior statements indicate that the respondent population was rather homogeneous in their views regarding sustainable food systems, a conclusion supported by the factor and cluster analysis. Some differences were detected between men and women, though these and other detected differences were a matter more of strength than direction. A more neo-liberal minority viewpoint was identified with the factor and cluster analysis. Significant shifts in viewpoint were not detected by the statistical analysis, factor analysis, or cluster analysis. Results from the factor analysis indicate a lessening of ambiguity (clarification of beliefs) over time, coupled with a moderating of viewpoint for a few participants.

While significant shifts in viewpoint were not observed, findings from a range of quantitative and qualitative methods indicate that the intervention did have an effect 
on viewpoints. Results from Survey One B and Two indicate that self-rating of clarification of personal beliefs and values was strong (between agree and strongly agree) and stable over time (nine months post). The interviews indicate that individual participants were able to change their thinking about issues or people and that the larger domain began to appreciate the systemic nature of the issue and the legitimacy and/or magnitude of efforts to address the issue. These findings are consistent with other multi-stakeholder process research that identified more expansive and integrative thinking regarding issues and players (Poncelet, 2001; Schusler, Decker, \& Pfeffer, 2003; Turcotte \& Pasquero, 2001).

It is important to note that the observed changes in viewpoint more often reflect a change in attitude about others and their perspectives rather than a shift in fundamental values or beliefs. Further, for the most part, viewpoint change appeared to be expansive rather than narrowing. As one respondent noted, "It broadened my sense of what is possible." Describing a how she came to better understand others' positions one interviewee noted:

Probably not values...I have more compassion for the people who are inbefore I might have been a little more derogatory about a farmer who is using GM crops or whatever and I understand now that it is really not them. They're forced into a corner and they have to make choices and they're just trying to keep their business going. On that level, I feel some of my beliefs have shifted a bit.

As Daniels and Walker (1996) note, it is likely unreasonable to expect significant 
viewpoint change to occur in a day - an assertion supported by theory pertaining to schema conservation. Schemas ${ }^{11}-$ the filters and templates that help us make sense of the world and guide us in what to pay attention to and what to make of the information - are, by design, highly conservative. They function to provide mental "short cuts" so that time is not spent evaluating each situation. Thus, schema accommodation is less common than schema assimilation ${ }^{12}$ (Carifo, 2005). "Threats" to existing schema (e.g., dissonance arising from critical reflection) may provoke anxiety or other uncomfortable emotions providing additional logic for the favoring of assimilation over accommodation (Brookfield, 1994; Carifo, 2005; Ettling, 2006; Taylor, 1998). Further, less transformation is expected to occur when participants hold similar viewpoints (Poncelet, 2001), a condition in this case. Observes Poncelet (2001), "significant alteration of people's subjectivities" is not guaranteed or inevitable and some will be "transformed more than others in these processes, and some will hardly shift at all. The argument being forwarded here is that such changes are possible and ... steps may even be taken to encourage such changes..." (p. 280).

\footnotetext{
${ }^{11}$ The terms schemata, mental models, frameworks, and filters are often used interchangeably, though come from distinct theorists. What is important to understand here is that people have mental processes that impose structure and meaning on the world.

${ }^{12}$ Assimilation represents local, small scale changes such as expanding your "bug" schema to include a type of insect you've never seen before, while accommodation represents more global changes such as determining that some insects are beneficial creatures rather than pests to be eradicated.
} 


\section{Tangible Outcomes}

Analysis thus far has examined intangible effects. In this section, tangible effects are considered using data from the Forum survey (Survey Two), follow-up survey (Survey One B), interviews, and archival evidence.

\section{Forum Survey}

At the time of the Forum, participants were asked on the Forum evaluation survey to respond to the following open-ended question: "In what ways do you think that attending this Forum will impact you professionally?" Nine respondents (13\%) identified programmatic changes. When asked, "In what ways do you think that attending this Forum will impact you personally?" twenty-two respondents (34\%) identified tangible effects - primarily related to food purchase decisions. For example:

- Increase my energy, commitment, knowledge to do the "little things" for local food systems (make time to go to the public markets, shop at locally-owned stores like New Seasons, talk to friends, neighbors, colleagues).

- It will change my food purchasing behavior and reaffirm my commitment to garden and buy local produce. 
- Pay far more attention to local products beyond the farmer's market.

- Provide a greater impetus for being mindful in purchasing decisions.

- I really will establish edible plants in my yard.

\section{Survey One-B (Follow-up Survey)}

On the follow-up survey (nine months after the Forum), participants were asked: "In what ways do you think that attending the April Food Economy Forum impacted you professionally?" Eight respondents (20\%) mentioned specific things that they have done as a result of attending the Forum. For example:

- Made a connection that led to a co-packing effort.

- I made contacts that have turned into major partnerships to further my work.

- Provided many new ideas for programs, areas of focus, etc.

When asked, "In what ways do you think that attending the April Food Economy Forum impacted you personally?" eight respondents (22\%) identified tangible effects similar to those provided at the time of the Forum. For example:

- Strengthened my commitment to making personal food choices that align with my beliefs.

- I shop differently!

- Shopping at New Seasons to support local healthy agriculture. 
- Telling others about markets/restaurants that do this.

- I bought Oregon Beef. Don't usually buy beef. Wanted to support them.

\section{Interviews}

As with the survey respondents, the primary effects mentioned by interviewees were new or revised programming at the professional level, and changes to food purchase behaviors. For example:

Oh, yeah... In terms of documenting that - I would say the grant that we signed on to do with $\mathrm{Y}$ was one and also signing onto a grant project with J...And there is an on-going collaboration with another agency where they are sending people to our program... Moving forward with $\mathrm{W}$, that was a meeting that obviously materialized because of CFM. I think there's very strong potential for collaboration even with other elements of, within my own agency because of CFM.

Well, it was at the Forum that $\mathrm{X}$ and $\mathrm{I}$ made the connection that Zenger Farm could be an Oregon Solutions Project. Now, that's led into our big meeting next month that [Oregon State] Governor Kitzhaber and [City of Portland] Commissioner Saltzman are hosting. In that sense, that's pretty huge!

[T] he actual connections that got made and the projects that actually happened...One of them was the Farmers Market [found a home at Ecotrust because key players met through CFM]. One of them that I just thought of in my head as we're talking was the fact that I knew the head of a local service organization and I got my friend on her board. That's a very tangible thing that happened. I also hooked her up with a local business leader who's a good friend of mine, who donated seeds and tools to the organization. It's interesting to think of the list of things of the social fabric, the social capital that's gotten built. [Goes on to detail how $\mathrm{s} / \mathrm{he}$ introduced two players and encouraged a hire and worked with two 
other organizations on a successful grant]. I could just keep going... I'm on the board of $\mathrm{X}$ because of that and $\mathrm{Y}$ is facilitating that process.

I would say that there probably is already specific impact in areas like the institutional food purchasing effort. The partners around the table who are people that can help get decisions made at different levels and the information that is being brought together -- it just totally advanced that discussion. The impact will likely be that any efforts will be more strategically focused.

Well gosh! Look at X from the Food Bank. I got acquainted with her/him through CFM, we've interacted on different things including this Monday s/he was one of the speakers on our panel about food security and food safety.

I think possibly some of my personal shopping is a bit different and I'm far more attentive to local purchase than I have been heretofore. And willing to pay a premium for some goods and some services that are local. Acknowledging that what goes around, comes around. So, I for one would really want to know if the organic apple is from China now. And wouldn't have even thought that one through ... I think principally, the acknowledgement of the fact that there might be a premium for local purchase, but it's very important.

\section{Archival Evidence}

Direct and indirect tangible effects identified in archival data include events, reports, and information sharing. Descriptions of these outcomes and outputs are provided below - by topic and chronologically. 
- Potluck Dinner and CFM Update Meeting, November 25th, 2002

The goal of this event was to maintain enthusiasm and momentum generated at the April Forum, announce Ecotrust's hosting of CFM, provide a space for sharing updates and networking, introduce AmeriCorps hires and provide an opportunity to meet in small groups around project areas. Approximately forty-five people attended this event.

- Sustainable Regional Food Economies, February 27, 2003

The purpose of this event was to consider how sustainable food systems and economic development are linked, what lessons learned from Oregon food entrepreneur projects, and current local opportunities for sustainable food entrepreneurship and economic development. ${ }^{13}$ Though open to all, recruitment targeted economic and community development specialists, growers, processors, food entrepreneurs, and food economy leaders. Admission was $\$ 5$ to $\$ 15$ sliding scale. Seasonal, sustainably produced refreshments were provided. The event was sponsored by Community Food

\footnotetext{
${ }^{13}$ Speakers were Dr. John Ikerd, Agricultural Economist, University of Missouri, Agricultural Economics; Jerry Gardner, Oregon Department of Agriculture; Dr. John Henry Wells, Food Innovation Center, respectively.
} 
Matters/Ecotrust, the OSU-ODA Food Innovation Center, OSU Extension, and the Oregon Farmers' Market Association. Attendance was approximately one hundred.

The event evaluation form can be found in Appendix D. Forty-eight evaluation forms were completed. This is approximately a $48 \%$ response rate, introducing potential non-response bias. On a 1 to 5 scale, with 1 being "poor" and 5 being "excellent," the quality of the three speakers was rated $4.89,3.41$, and 2.62 , respectively. The usefulness of the three speeches was rated $4.72,3.29,2.98$, respectively. The least favorably rated speech experienced a technological malfunction that was very distracting and had content deemed to be controversial by some attendees (they questioned the sustainability of a product being touted as such). The more moderately rated speech relayed a rather pessimistic, cautionary tale and focused on export markets (again raising questions about sustainability by some).

- Sustainable Northwest Conference, May 29, 2003

CFM members contributed to the planning of five food-related panels for a regional sustainability forum. These included sessions on food democracy (community based policy initiatives), land use, buying local, an overview of the region's food system, and sustainability in food enterprises from micro to multi-national. 
- Feeling the Squeeze: Consolidation in the Food System and Impacts to Producers and Community Health, Dr. William Heffernan, April 10, 2004

The purpose of this event was to learn about trends in food system consolidation and potential impacts. The event, held at PSU, was open to the public. A $\$ 2$ to $\$ 10$ donation was suggested, though no one was turned away for inability to pay. The event was sponsored by CFM and PSU's School of Community Health and School of Urban Studies and Planning. The event was made possible through a CFM member's offer to "piggy back" Dr. Heffernan's engagement at PSU with another event in Eugene, OR. Approximately forty-five people attended the event.

- Nourishing Kids and Communities: An Action Summit on Schools and Food, April 30, 2005

This half-day summit was geared toward educators, parents, youth, food service professionals, health professionals, and farmers. The objectives were to learn about innovative projects implemented in the lunchroom, classroom and school garden, and share ideas for new or expanded school food initiatives. A mid-day snack was provided and childcare was available. A $\$ 5$ donation was requested, though nobody was turned away for lack of funds. The event was sponsored by CFM, PSU's Schools of Community Health and Urban Studies and Planning, the Portland-Multnomah Food 
Policy Council, Portland Area Rethinking Schools, and PSU's Leadership in Ecology, Culture and Learning Program and Food Based Education Project. The event agenda (Appendix L) included large and small group activities. Speakers included representatives from the Oregon Department of Education, Portland Public Schools Food Service, $47^{\text {th }}$ Avenue Farm, ${ }^{14}$ Portland State University, Portland Area Rethinking Schools, ${ }^{15}$ Zenger Farm, ${ }^{16}$ and four Portland area schools. ${ }^{17}$ There were approximately 124 participants. Eighty-one evaluations were completed (65\% response rate with potential non-respondent bias). Overall, respondents agreed (51\%) or strongly agreed (44\%) that they found the event to be useful and most felt their opinions were heard (53\% agreed and $27 \%$ strongly agreed). Most agreed that they improved their understanding about school food issues (56\% agreed and $31 \%$ strongly agreed), even though prior to the event they had a strong understanding about school food issues (53\% agreed and $21 \%$ strongly agreed). Most participants learned things that will be helpful to their work (61\% agreed and $27 \%$ strongly agreed) and most said they made contacts that will be helpful to their work (51\% agreed and $35 \%$ strongly agreed),

\footnotetext{
${ }^{14}$ The $47^{\text {th }}$ Avenue Farm is a community supported agriculture (CSA) farm that, among other programs, partners with a local school to provide food and farm education.

${ }_{15}$ Rethinking Schools is a national non-profit organization with a critical pedagogy perspective.

${ }^{16}$ Zenger Farm is a non-profit educational farm in Portland.

${ }^{17}$ Trillium K-12 School, Sunnyside Environmental K-8 School, Abernathy Elementary, and Franklin High School.
} 
- Regional Food Assessment and Community Gathering, February 9, 2006

This event, co-hosted with Ecotrust, had two sessions. The morning session included a review of the Vivid Picture Project in California and discussion of implications of that project for a regional food system assessment in the Portland or Pacific Northwest region. The afternoon session was framed as an opportunity to welcome new members to the region's food community (i.e., significant new hires), share updates, request input or feedback, and network. A capacity crowd of more than 100 attended the morning session and approximately 60 people stayed for the afternoon. Forty-nine evaluations were completed $(-49 \%$ response rate, introducing potential nonrespondent bias) (Appendix $M$ ). Responses were favorable. The average score for the morning session was 3.84 (on a 4 point scale with $1=$ poor and $4=$ excellent). The average score for the afternoon session was 3.43. Input was sought on the merits of a food system assessment for this region; the average score was 4.98 on a five-point scale with 5 being the highest or most useful.

- $\quad$ Brown Bag on Sustainable Food Systems at PSU, February 23, 2006

The purpose of this gathering was to learn about Portland State University efforts to address sustainable food system issues. Panelists included representatives from the student run Food for Thought Café, food contractor Sodexho, the JEAN'S Farm 
student learning site, and the student garden program. The event was held at PSU, was open to the public, and was free of charge. There were approximately 50 attendees. Audience members included students, faculty, staff, alumni, and other community members, with students representing the majority. Twenty-eight evaluations were completed ( $\sim 56 \%$ response rate, introducing potential non-response rate). The overall event was rated (3.50) on a four-point scale (with $3=$ Good and $4=$ Excellent). To the statement, "at this event I increased my understanding about food systems at PSU," the mean rating was 6.43 (on a 1 to 7 scale with 7 being highest). Self-reported effects included learning about the subject matter and new ideas for students.

\section{Reports}

As detailed below, two reports to support sustainable food system efforts in the region were produced by CFM.

- Barriers and Opportunities to the Use of Regional and Sustainable Food Products by Local Institutions, June 2003

CFM partnered with the Portland/Multnomah Food Policy Council to produce "Barriers and Opportunities to the Use of Regional and Sustainable Food Products by 
Local Institutions." One of CFM's AmeriCorp volunteers was responsible for coordinating the Institutional Purchasing Advisory Team and conducting and analyzing the interviews. Twenty-seven interviews were conducted with institutional purchasers, growers, processors and produce distributors. The report was authored by the volunteer and CFM's director. The report informed institutional purchasing efforts for the city and county.

- Supporting Sustainable Regional Food Systems: A Roadmap to the Content, Processes, and Uses of Regional Food System Assessments, June 2006

This report provided an inventory of regional food system assessments in the US and Canada, and drew on interviews and a literature review to inform future assessment efforts. The report was intended to serve as a foundation for a food system assessment in the region. The report was prepared by one of CFM's graduate assistants and the director with data collection assistance provided by two PSU graduate interns and one community-based intern.

Food and Community Work Group

A faculty food and community work group (FACWG) was convened under the 
direction of CFM. The group defined a three-year vision that included improved networking and learning, research, curricular changes and/or certificates or minors, improved sustainable food system at PSU, creation of a center or program for food and community studies, and participation in local, regional, national and international teaching and scholarship initiatives. The group was successful in incorporating the topic of food systems into PSU's Declaration of Support for Sustainability. At the time of this writing, the group continues to meet, though its direction remains uncertain (e.g., loose learning community, partners in a certificate program, research collaborators, participants in a Center for Food and Community Studies).

\section{Additional Informational and Educational Services}

CFM provided a number of additional informational and educational services beyond events and reports. For example, CFM maintained a listserv of news and events related to regional food issues, created and distributed an informational brochure and poster board, provided input to regional food system efforts (e.g., to the Lents community food assessment, and Washington state's nascent food policy group), assisted PSU in increasing its print and video holdings related to food systems, created a book and video resource list, spoke to classes and community groups, and responded to requests for information. 
CFM staff worked with eight faculty in PSU's School of Community Health and School of Urban Studies and Planning to incorporate community food systems issues into classroom-based and community-based learning opportunities. Students were engaged in the topic of community food issues via readings, lectures, films and/or guest speakers. In the 2004/2005 school year eighteen courses, offered a total of twenty-two times throughout the year, brought the subject of food systems to more than 770 students. Of these 770 students, about 180 participated in community-based learning projects. In the $2005 / 2006$ school year approximately 590 students were reached in seventeen courses, with approximately 60 of these students participating in community-based service learning projects.

\section{$\underline{\text { Summary }}$}

Surveys, interviews, and archival evidence indicate that tangible outcomes can be attributed to CFM either directly or via relationships that were made while participating in the CFM collaboration. New programs were developed and existing programs enhanced, reports were written, events were held, and behaviors changed.

With respect to behavior change, the findings are also to be expected. The literature 
on behavior change and pro-environmental behavior suggests an array of factors as important - including awareness (knowledge of issue), care (saliency), locus of control, opportunity costs, sense of ownership, motivation, incentives, and support structures (Gove, 1994; Guagnano, Stern, \& Dietz, 1995; Stern, 2000; Stern, Dietz, \& Guagnano, 1998). In this case, the increased awareness, motivation, and inspiration observed in some participants may have supported the modest changes in behavior identified. Large or dramatic changes in individuals' behavior would not be predicted given the literature.

\section{Impacts on the Field}

A more difficult to measure, though important impact, is CFM's influence on the regional food system field or domain. As noted in the interviews, CFM's presence and activities influenced visibility of sustainable food system issues in the region and development of networks and partnerships to address these issues. Appreciation for the systemic nature of the issue and the legitimacy and/or magnitude of efforts to address the issue increased. For example:

I think CFM has done quite a bit to get people thinking and talking about food system issues. Just using the word food system and thinking about it as sort of a mosaic of different issues um...certainly the buzz around that in this community is due in no small part to the work of CFM. 
I also think that it [the Forum] made an impact for food industry folks who went, "wait a minute, there are a significant number of people talking this issue out in our state."

One for me personally was at my organization; people just did not get community food systems at all. So, it really took an organized network that had formed and me being a part of it to give myself some credibility. That this was something real, not only something happening in Oregon but a national and international movement.

I think you can legitimately say that the understanding is greater and the strategy is more focused and money is going to be used more effectively.

[P]eople in various parts of the food system or working on food system issues [became] more aware of what others in the food system do and got them to cross-fertilize and work on things together... People, who didn't know much about what the others did, now do.

The learning about other peoples' issues is really happening because...I think a lot of the people have worked in isolation or within the people that are like-minded - just like they are. And they haven't really had a clear understanding of other things [issues involved].

If we start looking at the overlaps here it would be really interesting...I can just imagine this chart of different groups or individuals... You're proving the substantial gains of building social capital.

Extension of learning by participants and increased "buzz" helped to shape the field.

For example, where initial efforts to engage Oregon State University (OSU) faculty in sustainable food system issues were sometimes met with resistance and/or skepticism, by July 2006 OSU Extension Service had identified "Sustainable Community Food Systems" as a recommended new programming area (Portland Metro Health and Food Systems Task Force, 2006): This recommendation came from a task force comprised of a number of members who participated in CFM. 
Another example of shaping the field involves a significant shift in commitment at Portland Public Schools to address local, sustainable, and healthful foods. As one PPS food service leader wrote, "Kristy is the one who is making food and farm connections a high priority for PPS now, but it is only possible because of the awareness building that has been happening since 2003 (or earlier). Your leadership through Community Food Matters has played a significant role in the progress."

A third example can be found regarding community food assessment. In this instance the Portland/Multnomah Food Policy Council (FPC) and the Coalition for a Livable Future (CLF) were both conducting community food assessments but were unaware of each other's work. CFM helped to bring these and other community partners together to discuss collaborative community assessment. Valuable relationships were made and protocols from the FPC assessment were shared with CLF, aiding their work and introducing a methodology that could facilitate comparison across the region.

Illustrating individual impacts of participation and extension to the field, one interviewee noted that a presentation s/he made while participating in MCLA process was so well received s/he was invited to share it dozens of times and it helped to shape a major food and agriculture initiative in California. This person remarks that this outcome never would have occurred were it not for the relational, substantive, and 
processual learning that $\mathrm{s} / \mathrm{he}$ gained through participation in the process. In another illustration, two participants in the MCLA process developed a program with native fishers and, though they have each left their respective posts, their organizations remain in partnership.

The regional food system field is quite different than when the CFM initiative began in June 2001. Community and sustainable food system issues have garnered much attention and have moved into mainstream conversations and policy deliberations. CFM would never think to claim responsibility for the increased attention to and support for sustainable food systems in the region. Numerous players labored to forward this agenda - regionally, national, and internationally. Further, contextual issues such as peak oil and global climate change helped to foreground the issue. Thus, without overstating the magnitude of these effects, it can be said that tangible and intangible, direct and indirect effects attributable to CFM likely contributed to in some way to domain changes.

\section{Synthesis}

In this case, the large group intervention and collaborative alliance evidenced a range of direct and indirect, tangible and intangible effects at individual and domain levels 
(Figure 1).

Figure 1: Case Effects

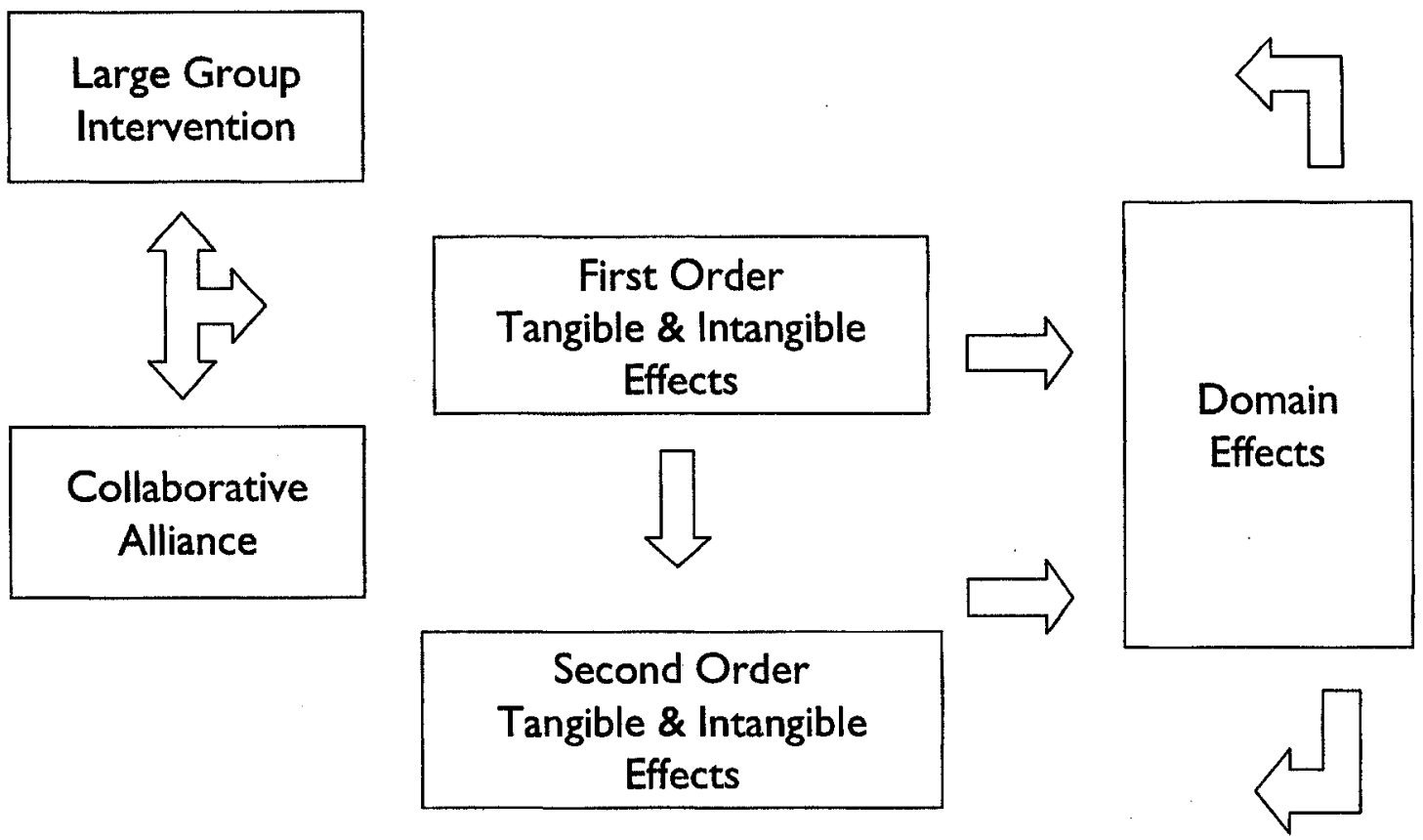

Consistent with MCLA goals, this process evidenced increased individual and system understanding and individual and collaborative activity supportive of movement towards a shared vision or goal. Participants, to varying degrees, gained appreciation for system interdependence, learned about domain issues (substantive learning) and members (relational learning), clarified beliefs or values, gained collaborative skills (processual learning), and discovered or renewed a sense of inspiration, commitment, or connection. New relationships were formed and existing relationships strengthened 
- resulting in knowledge transfer and creation, partnership, and program change.

Effects were often interrelated, for example, as knowledge, relations, and/or inspiration contributed to the production of tangible outputs. For the most part the findings regarding effects of this multi-stakeholder intervention are consistent with prior research on MSPs (e.g., Alvarez, Diemer, \& Stanford, 1999; Clarke, 2005;

Daniels \& Walker, 1996; Polanyi, 2001; Poncelet, 2001; Schafft \& Greenwood, 2003; Schusler, Decker, \& Pfeffer, 2003; Turcotte \& Pasquero, 2001), with the main exception being the divergence from Pelletier et al.'s (1999b) research on viewpoint change. $^{18}$

While a number of effects were identified, a complete accounting is not likely. Participants often are unaware of their learning or do not know its attribution - even when prompted (Hibbert \& Huxham, 2005; Imel \& Zengler, 2002; Kilpatrick, Barrett, \& Jones, 2003; Rossing, 1991). Similarly, Schafft and Greenwood (2003) found that participants were often unaware of the significant accomplishments directly and indirectly associated with the Search Conference. Noted one interviewee in this case:

I think the impact - it will be hard to ever ascertain the impact ...but the process of getting people together to think about solutions has created so

\footnotetext{
${ }^{18}$ Potential reasons for the divergence from Pelletier et al.'s (1999b) findings include the following: 1) the homogeneity and/or sustainability orientation of the population in this case may have influenced the outcome; 2) differences in Forum design or practices may have influenced the outcome (e.g., a particularly vocal and persuasive person, the types of presentations); 3) some of the reported viewpoint change in the New York case may represent not a lessoning of environmental or social justice concern but a change in thinking about the issue (e.g., someone may retain a strong commitment to hunger issues but change their view about welfare programs).
} 
many other relationships and information and the impacts are sort of like the big bang and everything sort of continues to fly out in all directions.

Understanding of MCLA processes entails considering not just what happened, but how and why. Having examined the effects of this MCLA case, attention turns now to concordance between this case and theories regarding MCLA design. 


\section{CHAPTER FIVE}

\section{CASE CONCORDANCE WITH MCLA DESIGN THEORY}

The second research question considers how a particular multi-stakeholder collaborative learning and action process matches with theory about MCLA design. That is, what does the literature have to say regarding design of successful MCLA processes and how does this case fit those theories? The chapter is structured in three parts. First is an analysis of the large group intervention (Forum). Second is an examination of the collaborative alliance. Third is a synthesis and discussion of findings.

\section{Forum}

\section{Design Considerations}

The Forum design in this case was informed by the literatures pertaining to large group interventions, dialogic learning, adult learning, and learning for social change and sustainability. A brief description of each and their influence on intervention 
design are provided below. The Forum agenda, annotated with design considerations, follows.

\section{Large Group Interventions}

While there are many types and applications of large-group interventions (LGI), most are informed by whole systems, constructivist, and participatory perspectives (Bramson \& Buss, 2002; Bryson \& Anderson, 2000; Bunker \& Alban, 1997; Griffin \& Purser, In Press). The whole systems perspective asserts that involvement of the full range of system stakeholders improves understanding of the system and fosters development of productive relationships. Related to this is the constructivist notion that engaging in dialogue with diverse others will allow people to create shared meanings and build relationships. Along constructivist lines, the participatory perspective suggests that people will support or "own" what they help create. Further, an orientation toward defining and achieving future visions rather than solving current problems is suggested to more effectively uplift and unleash energy (Bunker \& Alban, 1997; Weisbord, 1992). Some multi-stakeholder processes eschew the introduction of information by "experts" (e.g., Weisbord's Future Search), while others find such activities to be productive - particularly if strategies for critique are provided (e.g., Daniels \& Walker, 1996). Indeed, Blaug (1999), Ozawa (1991), and Pelletier et al. 
(2000) suggest that there may be instances of "good" dialogic form but "bad" dialogic content, thus supporting the introduction of high quality information of many types (Innes \& Booher, 1999).

LGI theory informed this design in numerous ways. Efforts were made to recruit the full range of system stakeholders. Activities designed to increase appreciation of system interdependence and conditions were included. The design was future oriented rather than focused on problem solving. Opportunities for self-organization were provided to allow for emergence. Time for small group work was allotted to facilitate relationship building, and address the "dilemma of voice" "(Bunker \& Alban, 1997). Presentation of information, with time for discussion, was included. Opportunities for the public expression of commitment suggested as facilitative of responsibility taking were provided.

\footnotetext{
${ }^{1}$ The dilemma of voice refers to the fact that in large group situations individuals have very little "air time" or opportunity to share their views.
} 
Dialogic Learning

Dialogue is suggested to play an important role in social learning, ${ }^{2}$ promoting understanding of issues, testing of ideas, clarification of values, development of relations, and discovery of common interests. Conceptualized as different than discussion or debate, dialogue aims to cultivate a quality of respectful listening and engagement in search of co-constructed meaning. Diverse theorists ${ }^{3}$ have contributed to dialogic theory and practice, though commonalities can be found. In the ideal, dialogic settings allow for free and full participation and create a space for thinking that is exploratory, reflective, creative, empathetic (perspective taking), and integrative (recognizing interconnectedness).

A number of theorists and practitioners of dialogue and collaborative learning and action have been tremendously influenced by Habermas' concepts of communicative

\footnotetext{
${ }^{2}$ As Parson \& Clark (1995) note, "the term social learning conceals great diversity." (p. 429). It may refer to individual learning shaped by the social world or learning by social aggregates. With MCLA our interest is in both. Individual learning is shaped by the social in numerous ways including modeling (learning by observing others), dialogue (learning in communication with others), guidance (curriculum prepared by others), culture and language (the linguistic and cultural lenses that shape interpretation of the world and sense of self), and environment (e.g. critical thinking is encouraged or not). At the same time, social learning is shaped by the individual. Examples include the way a group or community learns from the work of an educator, facilitator, or journalist, or when group learning is influenced by an individual's type of participation (e.g., disengaged, extractive, exchanging, exploring, or inhibiting). Social learning theories are at the heart of MCLA design, as the space is created for diverse stakeholders to learn with and from each other.

${ }^{3}$ Chief among these are Mikhail Bakhtin, David Bohm, Martin Buber, Hans-Georg Gadamer, Jurgen Habermas. CF Anderson, Cissna, \& Clune (2003) and Banathy \& Jenlick (2005).
} 
rationality and discourse ethics, evidenced primarily in attention to inclusiveness of all affected parties and accordance of equal standing to moral-practical reason, emotiveaesthetic reason, and scientific-technical reason (e.g., Blaug, 1999; Dryzek, 1990; Flyvbjerg, 2001; Forester, 1999; Healey, 2003; Innes, 2004). Bohmian dialogue has also been influential, though usually to a different set of theorists and practitioners (Cayer, 2005; Isaacs, 1999; Schein, 1993; Senge, Kleiner, Roberts, Ross, \& Smith, 1994). Bohmian dialogue aspires to bring diverse community members together in careful listening and suspension of judgment in order to cultivate consciousness of thought processes, more systemic thinking, and shared meaning.

In this case, dialogic principles were cultivated by trying to establish and model a tone of respectful listening and learning, and by providing opportunities to learn in dialogue with Forum participants. The Future Search method specifically does not provide for discussion about areas of conflict, suggesting that doing so diverts attention from productive work on areas of common ground. Such a strategy was seen to be in conflict with core dialogic principles, so the Future Search method was not considered for this case. 
Learning is shaped by a number of biological, psychological, cognitive, and sociocultural factors $^{4}$ (Carifo, 2005; Merriam \& Caffarella, 1999; D. Phillips \& Soltis, 2003), includes rational and extra-rational dimensions (Taylor, 2001), and may occur implicitly (non-conscious learning, tacit knowledge) or consciously ${ }^{5}$ (Argyris \& Schon, 1978; Bateson, 1972; Imel \& Zengler, 2002; Rossing, 1991; Taylor, 2001). In this case theories of learning informed the Forum design in a number of ways. First, a range of activities was included in order to accommodate diverse learning styles and ways of knowing (e.g., stories, "expert” presentations, small and large group work, dialogue). Second, the Forum included both a degree of structure in order to establish boundaries and guideposts for participants, and a degree of autonomy and selforganization so that participants could move toward areas that held for them interest, meaning, and value. Third, efforts were made to cultivate an environment that was psychologically and physically supportive of learning (e.g., where participants feel

\footnotetext{
${ }^{4}$ Among other things, a person's learning is affected in any situation by emotion, trust, identity, personality, memory (short term, working and long term), ways of knowing, intelligence, schemata, processing (central, peripheral, and parallel), existing knowledge, motivation, reinforcement, salience, attitude toward learning, beliefs about knowledge, and willingness to take risk or experiment (e.g., Cranton, 1992; Galbraith, 1998; Merriam \& Caffarella, 1999; Pahl-Wostl \& Hare, 2004; Schommer, 1998).

${ }^{5}$ Conscious learning without questioning of underlying assumptions or values is referred to as single loop, first order, or incremental learning; double loop, second order, or reframing refers to learning with reflection about underlying assumptions or values; triple loop, treble, or deutero learning refers to learning with reflection on the very process of learning (i.e., thinking about why and how we learn) (cf Argyris \& Schon, 1978; Bateson, 1972; Friedmann, 1987; Parson \& Clark, 1995).
} 
safe to share and disagree, and natural light, good air quality, and healthful foods and beverages are provided).

\section{Learning for Social Change and Sustainability}

Though initially focused on issues of social justice, learning for social change and sustainability has expanded to include issues of ecological justice as well. Theorists in this strand suggest that current biosocial dysfunction is rooted in a dominant worldview that sees humans as separate from nature, views nature as an unlimited resource to be exploited, inappropriately privileges some forms of reason and knowledge over others, and is individuocentric, commodifying, mechanistic, instrumental, and unwisely experimental (Bawden, 2005; Bowers, 1994; Heany, 1996; O'Sullivan, 1999; Orr, 1992; Schemel, 1996). In the critical tradition, power and knowledge, and their inextricable links, are also problematized. (Cervero \& Wilson, 2001; Freire, 2000; Usher, Bryant, \& Johnston, 1997; Welton, 1995). Formal and non-formal education is seen to have a responsibility to contribute to the manifestation of social and ecological justice.

While there is no unitary theory about learning for social change and sustainability there are some basic commonalties with respect to the how (participatory and 
democratic) and what (critical conscientization). Further, theory in this strand suggests a dialogic, social, collaborative, and reflective practice, with some theorists also suggesting attention to emotional or spiritual dimensions (e.g., Chile \& Simpson, 2004; English \& Gillen, 2000; Taylor, 2001; Tisdell, 2003). The Forum design was informed by learning for social change and sustainability theory to the extent that its aim was to promote a more ecologically and socially just food system, and it was designed to surface ecojustice issues and include participatory, democratic, dialogic, collaborative, and reflective elements.

Annotated Forum Agenda

The Forum Agenda annotated with design considerations is provided below. Theoretical influences on design are denoted as LGI (large group intervention), DL (dialogic learning), AL (adult learning), and LSCS (learning for social change and sustainability).

\section{$\underline{\text { Pre-Forum }}$}

A work group comprised of diverse food system stakeholders was involved in the Forum planning in order to validate appropriateness of the design and assist with 
stakeholder identification and recruitment (LGI). The Forum was held in the Jean Vollum Natural Capital Center - a LEED certified green building housing Ecotrust, the City's Office of Sustainable Development, and various environmentally friendly organizations and businesses. The site was selected for its ability to surface environmental themes and promote a comfortable physical learning space. The facility featured natural lighting and good air quality, ADA accessibility, non-toxic materials, and multi-modal transit options. Sustainably and locally produced meals, snacks, and beverages were provided free of charge to participants; non-disposable tableware was provided and composting and recycling facilities were easily accessible (AL, LSCS). Potential shortcomings of the location included lack of space for breakouts, few restrooms, and constrained parking options. Orientation information was sent to participants prior to the event in order to help provide structure and boundaries (AL) (Appendix O).

\section{Day One}

- Welcome and Overview (9:00 to 9:30)

The welcome and overview included a review of the process to date (i.e., how we got here), goals for the Forum, and housekeeping details (e.g., facilities, agenda). Appreciation for the diversity of stakeholders in the room was cultivated with a hand 
count of participants by group. ${ }^{6}$ Individual introductions in the large group were not made due to the number of participants and time constraints. Comments regarding listening, learning, and trust were shared in order to encourage dialogic habits. This Forum section was designed to orient participants, provide boundaries and structure, and set the tone (AL, DL, LGI).

- Keynote - Wes Jackson, Land Institute ${ }^{7}$ (9:30 to 10:30)

The keynote speech highlighted how rural and urban communities are inextricably linked and how the problems they face share common roots - those of certain habits of mind, taken for granted assumptions, and accounting methods that are not based on ecological economics or the realities of living systems. A fifteen-minute question and answer period was included. This Forum section was designed to introduce systems thinking, ecological economics, and critical reflection about conventional thoughts and practices (AL LSCS, SC).

\footnotetext{
${ }^{6}$ For example, asking food producers to raise their hands, then educators, etc.

${ }^{7}$ The Land Institute is a Kansas based non-profit organization that works on natural systems agricultural and connections between people and the land. Dr. Jackson was a MacArthur Fellow and recipient of the Right Livelihood Award. His participation at the Forum was made possible in part by a cost share with Illahe (then known as Institute for the Northwest) - a Portland based non-profit organization that hosts an annual speaker series on socio-ecological issues.
} 
- Regional Food System Presentation - Eileen Brady, Ecotrust (10:30 to 11:15)

This presentation introduced the concept of a healthy or sustainable regional food system. The presentation covered various facets of the food system and utilized stories, images, and assessment information. The purpose of this Forum section was to begin establishing a common language and frame of reference, concretize abstract principles, contextualize the issue of regional food systems (e.g., why it matters), set the stage for thinking systemically, surface ecojustice issues, and engage both head and heart (AL, LSCS).

- $\quad$ Break and move into small groups (11:15 to 11:30)

- Defining a Healthy Regional Food System (11:30 to 12:30)

Heterogeneous small groups were asked to address how a healthy regional food system should be defined and measured; including what indicators might be appropriate for doing so. This Forum section was designed to begin articulating a shared vision for the region's food system and have participants begin to engage with the material and with each other (AL, DL, LSCS). The idea was to work on something "concrete" in order to address the interests of participants eager to do more 
than just "talk" or "vision," while implicitly generating a sense of shared vision (i.e., in statements regarding the definition of a healthy food system).

- $\quad$ Lunch and Break (12:30 to 2:00)

Brief comments by Chef Greg Higgins and Portland/Multnomah Food Policy Council Co-Chair Rosemarie Cordello.

- $\quad$ Report-out of Food System Indicator Small Group Work (2:00 to 2:15)

The small group work defining a healthy regional food system was synthesized during lunch by a sub-team of the work group. The results were reported to the large group after lunch. The purpose of the report was to acknowledge the work done, identify the areas of common ground, begin to paint a picture of a sustainable food system, and set the stage for the next activity (LGI, LSCS). 
The modified Open Space $^{8}$ session was designed to identify and begin discussing projects likely to effectuate positive movement toward a sustainable regional food system. As described in Chapter Two, a work group had been defining priority projects; the Open Space session was conceptualized as a venue to refine these project ideas and identify potential partners while also offering the opportunity for new project ideas to emerge. Individual groups were asked to address: 1) Do we need a project like this? Why? What gap does it fill? 2) What would it look like if it were successful? 3) What do we need to do to get there? (AL, LGI). It was expected that draft project ideas being developed by the work group would be introduced, as well as some new project ideas.

- $\quad$ Regroup and Close for the Day (4:45 to 5:00)

A recap of the day was provided. The Community Food Matters declaration (Appendix P) was introduced and participants were offered the opportunity to provide

\footnotetext{
${ }^{8}$ Open Space Technology is a self-organizing large group intervention technique associated with Harrison Owen (Bryson \& Anderson, 2000; Bunker \& Alban, 1997). Conference attendees are offered the opportunity to "convene" a session on a topic that interests them, relevant to the main conference theme. Rooms and meeting times are identified for the sessions. Attendees self-select which session or sessions they would like to participate in. This case utilized a modified design as the convening and discussion was embedded as one component of a large group intervention.
} 
feedback on the statement. The declaration was designed to foster a sense of group identity, appreciation for system interconnection, and commitment to working together toward a sustainable regional food system (AL, LSCS). A reception was held from 5:00 to 6:30 to allow additional time for relationship building.

Day Two

- Welcome (9:00 to 9:30)

A recap of the prior day and overview of the coming day was provided. This activity was designed to acknowledge the substantial work done thus far and orient the participants to the day's activities (AL). Participants were invited to view the "gallery" of action agendas and add their name and/or comments if they were interested in doing so.

- $\quad$ Story Panel (9:15 to $10: 15)$

Two two-member panels shared their personal stories pertaining to an aspect of sustainable food systems. The first panel included Brian Rohter, CEO of New 
Seasons Market ${ }^{9}$ and Doc Hatfield, an Oregon Country Beef founding rancher ${ }^{10}$; the second included Jen Anonia, Gardens Program Manager for FOOD for Lane County ${ }^{11}$ and Dove Miller, a Youth Farm Crew member. Panelists were requested to highlight economic, environmental, human, and cultural sustainability. Panelists were chosen to represent rural and urban perspectives. The purpose of this Forum activity was to help envision relationships between people and the planet in a values-based sustainable food system. Time for questions and answers was allotted (Al, DL, LSCS).

- $\quad$ Reflective Inquiry $10: 15$ to $12: 15$

This dialogic exercise was led by Scott Dawson, Dean of PSU's School of Business and Leslie McBride, Professor in PSU's School of Community Health. The concept of dialogue (Bohmian) was introduced and participants were invited to reflect on and respond to the following: "After the last two days, what question are you living with?" The purpose of this Forum activity was to provide a space for reflection, critical

\footnotetext{
${ }^{9}$ An independently owned and operated full service grocery store chain in the Portland metropolitan area known for its commitment to regional foods and service.

${ }^{10}$ Now known as Country Natural Beef, this cooperative of family owned ranches features grass fed, Food Alliance certified beef product.

${ }^{11}$ FOOD for Lane County, the regional food bank serving Lane County, Oregon, provides a variety of programs designed not only to deliver emergency food but also to address root causes of hunger. The Youth Farm is an educational work site for alternative schools and at-risk youth. Twelve to eighteen Youth Farm Crew members, ages 14 to 17 years, are hired each year to gain experience in food production, customer service, and small business management by producing for and managing a farm stand and CSA program.
} 
thinking, integrating the Forum experience, hearing different perspectives, and building understandings and relationships (AL, DL).

- $\quad$ Lunch $(12: 15$ to $1: 30)$

- $\quad$ Closure $(1: 30$ to $2: 00)$

The closing session included a review of next steps, time to complete the Forum evaluation and Next Steps survey, and an opportunity to sign the Community Food Matters Declaration. This Forum component was designed to help contextualize and integrate the past two days' events, acknowledge people's participation, and provide a sense of direction for future action (AL, LGI).

\section{Findings}

Four methods of inquiry were used to explore concordance between the Forum and theory informing design. These include the Forum evaluation survey, Open Space Action Group documentation, Forum post-survey (Survey One B), and interviews. In the interest of narrative cohesion, results from each of these four methods are presented sequentially below followed by a synthesis and discussion that also draws upon participant observations. 


\section{Forum Survey}

As noted in Chapter Two, seventy-one of the 100 Forum attendees completed the Forum evaluation survey. This is a reasonable response rate, though the potential for non-respondent bias exists.

On the Forum survey, respondents were asked to rate fifteen statements related to the design of the Forum. The statements and mean responses are listed in Table 27. The following five-point Likert scale was provided for each question:

$\begin{array}{ccccc}1 & 2 & 3 & 4 & 5 \\ \text { Strongly } & \text { Disagree } & \text { Not } & \text { Agree } & \text { Strongly } \\ \text { Disagree } & & \text { Sure } & & \text { Agree }\end{array}$


Table 27: Forum Evaluation

\begin{tabular}{|l|l|}
\hline Question & Score \\
\hline Overall, I found this Forum to be worthwhile. & 4.54 \\
\hline I made contacts that will be helpful to my work. & 4.45 \\
\hline $\begin{array}{l}\text { The Forum provided a good start to building a shared vision for the } \\
\text { region's food system. }\end{array}$ & 4.25 \\
\hline The issues being discussed were relevant to me. & 4.39 \\
\hline A climate of trust and respect was fostered. & 4.46 \\
\hline Most Forum participants seemed to listen sincerely to each other. & 4.46 \\
\hline I felt that I had the opportunity to be heard. & 4.54 \\
\hline \begin{tabular}{l} 
It felt safe to bring up different opinions or to disagree. \\
\hline $\begin{array}{l}\text { All or most of the relevant interests in the region's food system } \\
\text { were represented at the Forum. }\end{array}$
\end{tabular} & 4.21 \\
\hline $\begin{array}{l}\text { Overall, it seemed that there was enough time for each of the } \\
\text { activities. }\end{array}$ & 2.87 \\
\hline I felt engaged through all or most of the Forum. & 3.55 \\
\hline $\begin{array}{l}\text { Prior to this Forum I had a high level of knowledge about regional } \\
\text { food system issues. }\end{array}$ & 4.59 \\
\hline $\begin{array}{l}\text { At the Forum I increased my understanding about the health of this } \\
\text { region's food system. }\end{array}$ & 4.25 \\
\hline $\begin{array}{l}\text { Participating in the Forum helped me clarify my own beliefs and } \\
\text { values about sustainable food systems. }\end{array}$ & 4.21 \\
\hline The facilities were comfortable. & 4.12 \\
\hline
\end{tabular}


Respondents were also asked to rate the open space breakout group they participated in as follows:

\begin{tabular}{lcll}
4 & 3 & \multicolumn{1}{c}{2} & \multicolumn{1}{c}{1} \\
Very & Worthwhile & A Little & Not Very \\
Worthwhile & & Worthwhile & Worthwhile
\end{tabular}

Forty-nine respondents replied to this question ( $69 \%$ of surveys and $\sim 49 \%$ of participants). The mean score was 3.18 .

Participants were asked in an open-ended format to respond to the following statement: "The best things about the Forum were..." There were sixty responses to this question ( $85 \%$ of surveys and approximately $60 \%$ of Forum attendees). Most respondents identified more than one item. Nineteen respondents (32\%) identified connections and networking: for example, "Putting faces to names. Meeting new people. Hearing stories. Time to nurture new relationships," and "Opportunity to meet/network with potential collaborators." Presentations were identified by twenty respondents (33\%), with remarks pertaining to the panels, the keynote, the food system overview, or a mix. These respondents found the presentations to be informative and/or inspirational. For example, "the inspiring duos that shared their stories" and "hearing narratives/models of hope/success." Thirteen respondents (22\%) felt that the best thing about the Forum was the "good people" in the room; for example, "The people! Engaged, interesting, challenging, good, thoughtful, caring human beings." Eleven respondents (18\%) mentioned the food and four (7\%) 
mentioned the venue. Seven (12\%) respondents made comments about the mix of methods and four (7\%) made comments regarding the agenda and facilitation. For example, "Excellent planning and facilitation!" "Well organized, good balance between presentation and attendee participation, and fun! " and "Very good balance of interaction and lecture/panels. A very community-like gathering, something that is very unique." Nine respondents (15\%) mentioned the breakout time and three (5\%) mentioned the dialogue. Five (8\%) mentioned the energy; for example, "all the energy and beginning to build community around issues." Five respondents (8\%) mentioned the breadth of participants or diversity and five $(8 \%)$ mentioned the exchange of ideas.

Participants were also asked in an open-ended format to respond to the following statement: "Areas for improvement include..." There were forty-six responses to this question (65\% of surveys and approximately $46 \%$ of Forum attendees). Many respondents provided more than one answer. Fifteen respondents $(33 \%)$ made comments about the need for more diversity in the room (particularly from minority, low income, and "mainstream" agriculture and food industry populations), with a few adding comments such as "No great ideas on how to do this" and "I know it's HARD." Nine respondents (20\%) offered suggestions to improve networking; for example, "Space for groups' hand out materials (show and tell tables)," "more opportunities to share with each other about the details of each others' projects," and "list of attendees with names and addresses and phone at beginning of conference so 
more targeted networking can happen while ideas fresh!" Beyond diversity and networking there were no other strong themes. Five respondents $(11 \%)$ made suggestions regarding clarity of goals and next steps and three (7\%) found the facilitation of their small group lacking. Five respondents (11\%) made comments about the space being too hard to hear in and four (9\%) suggested more or longer breaks. Three respondents (7\%) made comments about the Open Space activity (longer, more structured, and later in the event "once people were more relaxed and networked with each other"). Three respondents (7\%) wanted deeper discussion and more information on "obstacles for progress" and two people (4\%) did not value the dialogue activity.

Overall, Forum survey results indicate that the event was well received: the mean score for "worthwhile" was 4.54 (between agree and strongly agree). The mix of activities and group sizes worked well and respondents regarded the physical and psychological space as comfortable. A climate of trust and respect was cultivated and participants felt that they had an opportunity to be heard and were sincerely listened to. Consistent with findings presented in Chapter Four, relational and substantive learning were identified - even though there was a lack of representation from the full range of system stakeholders and respondents self-identified a relatively strong baseline level of knowledge about the topic. Also consistent with the findings on effects, participants reported that one of the best things about the Forum was the 
connection that occurred in a networking sense and a supportive, energizing sense. Although a specific visioning exercise was not included, participants felt that the Forum provided a good start toward building a shared vision for the region's food system (4.25 of 5). A potential design weakness identified in the survey includes an inadequate amount of time for all of the activities.

\section{Open Space Action Groups}

As noted above, the Open Space Breakout activity was conceived as an opportunity to further vet the work group's project ideas and identify appropriate partners and resources, while also affording the opportunity for new project ideas and partnerships to emerge. In actuality, many of the project ideas that the work group had been working on did not get offered as an Open Space session (i.e., when offered the opportunity, some work group members did not choose to "convene" a session on a project proposal they had been working on). Thus, the Open Space activity did not meet its objective of serving as a refinement of draft project ideas. Eight groups convened. These are summarized below.

The Outreach to Policy Makers Group suggested two projects: gather data on true costs of the current food system and convey this to key lawmakers and explore the 
establishment of an Oregon Food Policy Council. Two of the three contacts listed for this group were members of the Launch Team. Data collection and dissemination became a priority project of CFM and links to policy were explicitly made in the final concept paper.

The Waste Reduction in Food Processing Group identified three main objectives: capture/convert "spent" hens to charitable food, capture metro area food waste (glean what is usable for human consumption and transport remainder to Three Mile Canyon Dairy), have the DEQ contact participating with the group meet with local progressive producer to assess energy saving potential. None of the contacts listed for this group were members of the Launch Team. None of these three objectives were incorporated into CFM planning, however waste minimization themes were incorporated into the regional food system indicator work and food economy programming and proposals.

The Agricultural Land Protection Group identified the objectives of designating land inside and outside of the UGB for food production, and protecting small farms with land trusts and modified land-use laws and regulations. Their next steps included identifying research organizations and policy makers to assist. No contact person was identified. The issue of farmland research and policy was incorporated into CFM programming and policy via assignment of a CFM AmeriCorps researcher to the Food 
Policy Council Land Use subcommittee and incorporating land use issues into data collection and dissemination priorities.

The Education (Community Food Literacy) Team identified the following priorities: conference of youth/peer educators, local food "day" event, action kits for celebration, website including calendar and resource directory, listserv, increased networking, and involving target audience members in discussions. The contact person listed was a member of the Launch Team. A follow-up meeting was scheduled and held. The group met regularly for approximately one year, with some networking and partnering continuing after that. A listserv was established to facilitate communication (e.g., resource sharing, distributing minutes, seeking input). Resource sharing occurred at the meetings, via the listserv, and at some gatherings with other youth farm/garden educators. A major focus of the group was the creation of a Seed to Supper Curriculum Concept Paper (Appendix Q). Despite extensive effort to develop the Seed to Supper project the team ultimately did not approach any funder. This was due to a lack of time to complete the proposal and failure to identify a "host" institution. Some effort went into putting together a resource list of farm and garden education opportunities, though the list was not widely disseminated. The idea of a Harvest Festival was abandoned as members determined they did not have the capacity to follow-through. At one point (Spring 2004) a conversation was initiated with two faculty in PSU's School of Education regarding their interest in hosting the Seed to 
Supper project: the conversation was amiable but the proposal did not come to fruition. CFM co-hosted a major event on schools and food (Chapter Four and Appendix L), with many members of the team involved as panelists, resource people, and/or participants.

The Rural-Urban Bridges Group generated a lengthy list of project ideas focusing on increasing awareness/support for Oregon products and building farmer participation. The group identified three contact persons, one of whom served on the Launch Team. The group did not meet again. A number of the project ideas can be identified in initiatives that have emerged internal and external to CFM, though these activities were not a direct result of any CFM effort.

The Mapping Group expressed interested in collecting and sharing information. Their identified next steps included support for existing efforts, team building, and creating a task force to make recommendations. Two contacts were listed, neither of whom served on the Launch Team. The group did not meet again. Data collection, mapping, and dissemination and policy links were incorporated into the final CFM Concept Paper. Some of the linkages suggested between growers and consumers have been undertaken by others (e.g. Ecotrust, Food Alliance, Oregon Tilth), though independently of any efforts of this group. 
The Bridges to Processors, Buyers, and Institutions Group considered how to establish contact with produce buyers at chain stores or processors for the purpose of creating awareness of community food issues. Two contacts were listed, one of whom served on the Launch Team. The group did not meet again. The interest in increased institutional purchasing was supported by the research conducted by CFM in collaboration with the Portland/Multnomah Food Policy Council.

The Food Economy Entrepreneurship Group identified barriers and responses related to financing, processing, distribution, and economies. Three next steps were defined: Regional Creative Financing Forum, Value Chain, and Grant Proposal. Four contacts were listed, three of whom served on the Launch Team. The two contacts listed for the value added piece went on to develop a successful co-packing agreement. The contacts listed for the grant proposal submitted a Regional Investment Board Grant (not funded, likely due in part to the size of the request and the number of competing proposals). Many of the ideas in the grant proposal were further developed into CFM's concept paper and into partners' programming. The status of the regional creative financing Forum is not known: the "convener" lives in Seattle and communication was not maintained (however, some participants continued to network 
via the BALLE group ${ }^{12}$ that emerged around that time, with which that convener is affiliated).

Most action groups (six of eight) did not meet again and very few of the identified action steps were completed by group members as part of an action group. As noted in Chapter One, failure to actualize action agendas is a common problem identified in the literature. This indicates that design for and expectation of action agenda components in LGIs needs to be seriously reconsidered. That said, as noted above, participants who evaluated the Open Space activity found it to be worthwhile (mean score of 3.18 on a four-point scale). Further, content from seven of the eight Open Space groups made its way into CFM programming and/or programming of other organizations. Thus, consistent with Pelletier (2003), Schafft and Greenwood (2003), Innes and Booher(1999) and others, additional metrics may be necessary for evaluating the action component of large group interventions.

\section{Post-Survey}

On the post-survey administered nine months after the Forum, participants were asked, "In retrospect, what were the best things about the April Building a Regional Food

\footnotetext{
${ }^{12}$ BALLE, the Business Alliance for Local Living Economies, is an alliance of local business networks. The Portland group is called the Sustainable Business Network of Portland.
} 
Economy Forum"? Thirty-five respondents answered the question (71\% percent of surveys and approximately $35 \%$ of Forum participants). Possible explanations for the lower response rate to this question on the post-survey may be that open-ended questions take more time to complete and were at the end of the survey (survey fatigue), and/or that the respondent felt they had already answered the question on the Forum survey. While the response rate is lower, the types of responses are consistent with the Forum survey responses. Nineteen respondents (54\%) identified networking and contacts (e.g. "connections/contacts made," "opportunity to explore potential partnerships," "created an environment where everyone could connect and begin to work together," "learning about each other and our work and interests," "opportunity to connect with a wide range of interest groups and individuals"). Five respondents (14\%) mentioned the diversity of perspectives represented. Presentations were identified by fifteen respondents ( $43 \%$ ), with people remarking on the panels, the keynote, the food system overview, or a mix. Three people (9\%) commented on inspiration and three (9\%) on the people (e.g., "The passion of the people in attendance. I still get a charge from all of the shared energy and hope when I reflect upon the Forum").

On the post-survey participants were also asked, "In retrospect, what improvements could have been made to the April Building a Regional Food Economy Forum?" Thirty-three respondents answered the question (67\%). The most prominent theme 
relates to diversity, with nine respondents (27\%) suggesting that the full range of stakeholders was not adequately represented. No other theme emerged strongly: four (12\%) said none; four (12\%) comments were made about the amount of time or depth for breakouts, two (6\%) suggested better space for the breakouts, and two (6\%) noted that "the open space section didn't quite go as planned"; three (9\%) suggested more clarity regarding outcomes and next steps and three (9\%) suggested more or better follow-up.

Findings from the post-survey are consistent with those of the Forum evaluation survey, with respondents reporting increased understanding of issues and connections to people in the region's food system. The findings are also consistent with the relational and substantive learning effects identified in Chapter Four.

\section{Interviews}

Interviewees were asked to share their thoughts about the April Forum. Overall, the comments were positive and consistent with Forum design goals. For example:

I remember feeling that it was a success.

It reminds everyone that, "Well, you all are part of this."

I think it was a good mix of information and opportunity for discussion and inspiration too. I think it was well structured. 
The conference last year really helped pull things together- last April. Getting everyone in the room.

Four interviewees noted that they felt there was not adequate diversity in the room.

For example, "I was disappointed, and I said this there, that there weren't more agriculturists there" and "It would have been nice to have more stakeholders in the room, more factions represented."

Three interviewees commented on the Open Space action planning: two wondered if it had been premature to begin action planning and one felt that that there was not adequate follow-up afterward.

One interviewee noted how powerful the panel presentations were:

at the beginning I wasn't very excited about the panels where people were going to be sharing partnerships that have worked out or relationship building because I didn't really think I would get that much out of it. And I ended up really enjoying that... I felt really impacted by just the power...and envisioning that we could create something similar... We have done some research around that [Youth Farm] and it's possible in the future.

The positive comments regarding the panel presentations demonstrate how even in "passive" formats participants can actively engage with the material and "construct" meaning. The presentations helped to paint a picture of the system, suggest some system contradictions, illustrate possibilities, and provide a common reference point. 
One interviewee remarked that s/he felt that the event was "almost naïve in the way that it presented some ideas," that it was "such an extreme, you know the information that was presented there. Much of the information really wasn't...(long pause) workable? ... our farmer left when the discussion turned so totally to, 'It's got to be organic,' that it was just such an extreme that he finally just said, 'No, this is too much." This was a surprising finding, both in its deviance from other results and contrariness to design considerations. Although care was taken in the invitation and opening remarks to frame the issue in a broad, mainstream, non-threatening way (e.g., as an issue of supporting the region and never mentioning organic), there was at least one individual whose frames provided too much resistance for them to engage with diverse others (Gray, 2004; Snow, Rochford Jr., Worden, \& Benford, 1986). Further, although the remarks during the Forum set a tone of listening and learning, acknowledging the co-constructed and provisional status of definitions of a healthy regional food system, there were some participants (or at least one) that felt unable or unwilling to engage in a conversation about the issue. There are at least two explanations for this finding. First, it may be that there was a dominant discourse that alienated one or more participants - either because they did not agree with the discourse, did not have the linguistic capital to successfully engage with the material, and/or felt uncomfortable surfacing difference in the group (Everett \& Jamal, 2004; Jamal, Stein, \& Harper, 2002; Poncelet, 2001a). Second, and perhaps related to the first, it may be that some individual's margin for learning was not sufficient to the task 
- particularly if they were feeling alienated or emotions were running high (e.g., Bernard \& Armstrong, 1998; Brookfield, 1994; Ellsworth, 1989).

Overall, interviewees deemed the Forum to be well organized and successful, though possibly lacking in diversity and weak with respect to the action planning. One interviewee's remarks raise questions regarding the ability to create a safe and unbiased place for dialogic learning; however, it is not clear to what degree the participant's concerns represent a flaw in the Forum design and/or the idiosyncratic inability of a particular individual to successfully engage.

\section{Summary of Forum Findings}

The Forum design was informed by theory pertaining to large group interventions, dialogic learning, adult learning, and learning for social change and sustainability. Synthesizing the Forum evaluation findings and participant observations, the following paragraphs consider how theoretically informed design considerations played out in this case.

Findings regarding the whole system perspective of large group interventions are mixed. On one hand the full diversity of stakeholders was not present. On the Forum 
evaluation survey, the mean response to the five-point Likert scale question, "All or most of the relevant interests in the region's food system were represented at the Forum" was 2.87 (with $2=$ disagree and $3=$ not sure). Concerns about a lack of diversity, particularly with respect to food and farm businesses and low income and minority populations, also appeared in some interview and survey evaluation comments ( $33 \%$ of respondents to the Forum evaluation and $27 \%$ of respondents to the post-survey open ended question about areas for improvement). Challenges recruiting or involving the full diversity of stakeholders is a common problem noted in the literature (Everett \& Jamal, 2004; Polanyi, 2001; Schafft \& Greenwood, 2003). On the other hand, a small minority of Forum participants (8\% Forum survey, $14 \%$ post-survey) thought that one of the best things about the Forum was that it "brought together a wide range of professionals interested in the same macro-big picture results but working on micro-components - opportunity to meet and learn; so often we work in isolation and are not aware of what is going on elsewhere." Most importantly, system appreciation, substantive learning, and relational learning effects associated with a whole systems perspective were evidenced. Thus, while the full diversity of food system stakeholders may have been lacking, the amount of diversity was notable for at least some participants and was sufficient to support understanding and relationship-building goals associated with the whole system perspective. 
The Forum was designed to be participatory, fair, and engaging: evaluations suggest these objectives were met. On the five-point Likert scale, with 5 being strongly agree, respondents found a climate of trust and respect fostered (4.46) and felt safe bringing up different opinions or disagreeing (4.21). Respondents felt that they had the opportunity to be heard (4.54) and that participants seemed to listen sincerely (4.46). Respondents felt engaged through all or most of the Forum (4.12) and found the issues being discussed to be relevant (4.39). As noted above, while the event was engaging and comfortable for a majority of participants, it was not so for at least one. Whether this is attributable to Forum design flaws, an alienating dominant discourse, and/or the participant's weak ability to engage with diversity is not known - nor is the question of whether any other participants felt similarly. It may be that even with a concerted effort to create a supportive dialogic setting, participants with a minority viewpoint may feel too uncomfortable to effectively participate. Or it may be that, even with best practices, sometime you can't please all of the people all of the time.

Overall, attention to factors supporting a positive learning environment met with success. The blend of activities seemed to work well, with some respondents noting that they appreciated the speakers, some the small break-out groups, and some the mix. The facilities were comfortable, despite some problems with acoustics (4.49 of 5). Regarding pace, while an effort was made to ensure that the event did not feel rushed, the agenda was quite full. Thus, there was not ample time for breaks or 
processing, and some activities could have benefited from additional discussion time. Participant observer notes identify some concern about the timeframe, especially for breaks. This concern was confirmed in some of the open-ended survey responses as well as the Likert-scale question regarding adequate time for each of the activities (3.55 with $3=$ not sure and $4=$ agree).

The LGI literature is mixed with respect to the role or appropriateness of speakers (i.e., a presentation given to an audience). One view suggests that knowledge to understand and shape the system is held by the participants in the room and introducing speakers that aren't members of the group fosters dependency behaviors (e.g. Future Search, Open Space). The other view suggests that inclusion of speakers can be appropriate for meeting social learning and system understanding goals (e.g., meet differing learning styles, introduce new information) - particularly when there is an opportunity to question or critique (e.g., Daniels \& Walker, 1996; Pelletier, Kraak, McCullum, Uusitalo, \& Rich, 1999b; Schusler, Decker, \& Pfeffer, 2003). This evaluation supports the latter view. Many survey respondents noted how valuable the presentations were - providing both information and inspiration.

The role of dialogue in LGIs varies by type of intervention. While most designs aim to foster relationship building and improve system understanding through dialogic interaction among participants, few cultivate dialogue in a Bohmian sense. In fact, 
some designs consciously avoid exploration of areas of disagreement (e.g., Future Search) or narrowly frame such conversations (e.g., some Roundtables, cf Jamal (2002)). In this case, the design team had an interest in fostering critical reflection about food system sustainability, surfacing taken for granted assumptions, and cultivating consciousness of thought processes. Thus, a dialogue exercise led by two practitioners and teachers of dialogue was included. The timeframe for this exercise, coupled with the size of the group, did not permit a deep or extended dialogue session - likely contributing to the mixed evaluation results: a few respondents identified the dialogue session on their list of "best things about the Forum," though it was also suggested to be "spacey" or "slightly patronizing" by others. One respondent wrote, "the part with Scott Dawson was interesting but I'm not sure it really added much to our understanding." Effort was also made to foster dialogic skill during the Forum (e.g., Burbules, 1993; Burbules \& Rice, 1991; Isaacs, 1999; Pruitt, Waddell, Kaeufer, \& Parrot, 2005). For example, the opening remarks noted:

You'll notice time for listening and learning. Those are two key words - listening and learning. They are key to our ability to develop the shared understandings and agreements necessary if we want to cultivate a sustainable food system. I would like to emphasize that as we listen and learn, trust and respect are core values in this process. We ask that you honor the diversity of experiences and opinions in the room - and that we aim to create understandings, not take positions or win debates.

As noted above, survey respondents agreed that the Forum cultivated a climate of respect, trust, listening, and learning. 
The Forum was designed to foster critical reflection which is suggested as being important to some types of learning (e.g., Berk \& Burbules, 1999; Brookfield, 1987; Freire, 2000; Mezirow, 1990; Schon, 1983). This included the dialogue activity, question and answer activities, and small group discussions. The findings reveal that learning occurred, however, the research did not attempt to measure whether and how participants engaged critically with the material at the event or after, and whether the learning that occurred can be attributed to critical reflection.

Development of common ground and shared visions is important to most LGI designs. In the case of the Forum, there was not an explicit visioning activity. Rather, the objective was embedded in three activities: The small group activity regarding indicators of a sustainable regional food system was designed to surface areas of common ground and vision, the Declaration signing provided an opportunity to symbolically name CFM values and vision and gauge the group's level of agreement, and the Next Steps Form assessed support for the proposed collaborative, systemic initiative to address regional food system issues. While development of a shared vision was not an explicit activity at the Forum, there are indications that it was fostered: Forum evaluation survey respondents felt that "The Forum provided a good start to building a shared vision for the region's food system" (4.25 of 5). There were also a few responses on the pre- and post-surveys that mentioned building of a shared vision or moving forward; for example, "the energy of shared vision being reflected, 
affirmed, shared, convened, focused, and released to go outward still connected." At the same time, there were missed opportunities for building a shared vision particularly by eliminating small group report outs and discussion. Due to time constraints the reports from the indicators break-out were synthesized and reported as a whole to the large group, and the reports from the Open Space planning were posted, with participants invited to make additions or comments or sign-up. While this strategy accommodated time constraints, it likely short-changed learning and vision building objectives. As one survey respondent noted, "There was a lot of vagueness, a lot of ideas that need to somehow come together. I don't think we've collectively identified how we see our pieces as an effective whole."

The small group breakout session to define and measure a healthy regional system was designed as a participatory, constructivist activity to begin building shared understandings about and vision for the region's food system. It was scheduled midway through the first day, after the presentations that were designed to help contextualize the issue. Participants were pre-assigned to heterogeneous groups in an attempt to foster sharing of diverse perspectives and building new relationships. The question to be addressed was shared in the large group setting, repeated a few times and projected on the wall (How do we define and measure a healthy regional food system?). Each group was facilitated by either an organizational partner familiar with small group facilitation or a student in planning and community development. 
Facilitators were given instructions by email and/or the morning of the event. Participant observation notes indicate that when checking in on the breakout groups many were not on task. A lot of the conversations had drifted to perceived problems and solutions regarding the food system. An attempt was made to remind participants of the importance of defining "where we want to go" before jumping into "what to do." Overall, the groups were able to complete the task and results were synthesized and reported thematically back to the large group. The problem of staying on task may speak to the need for better facilitators - though many of the LGI theorists suggest that facilitators for the small group sessions are not required as participants can self-manage and select a facilitator from within the group (e.g., Weisbord, 1992). The problem may also indicate that this was not the right activity or that the activity was not scheduled at the right time (i.e., participants may need to first "air" interests or concerns).

A central feature of many LGIs is the provision of space and time for participants to self-organize into groups to develop and implement action agendas. As noted earlier, the action agenda activity at the Forum was an Open Space session - a major objective of which was to debut, review, and move forward where appropriate the project ideas that working group members had been developing. Findings regarding selforganization in this case are mixed at best. As one interviewee noted, the Open Space session did not go as planned, "mostly because people didn't step up and call out the 
topics or projects we were already working on. I don't know how this could have been improved though." Why didn't members convene a group on their project? Did they not want to take a leadership role? Was this an early indication that they did not feel sufficiently invested or empowered to proceed? Were they simply interested in attending one of the other sessions? At the same time, although most of the groups did not coalesce and implement an action agenda, many participants found this break-out exercise to be useful, with some noting it on their list of "best things about the Forum," and the time being rated as "worthwhile" on the Forum evaluation survey (mean score of 3.18 on a 4 point Likert scale).

Consistent with other research, many of the action plans were not implemented, raising significant questions about the assumption that people will "own" and implement what they help to define (e.g., Alvarez, Diemer, \& Stanford, 1999; Oels, 2002; Pelletier, Kraak, McCullum, Uusitalo, \& Rich, 1999a; Schafft \& Greenwood, 2003; Schusler, Decker, \& Pfeffer, 2003). In some cases the "action plans" were not sufficiently articulated, in other cases the full complement of stakeholders needed to move forward was not present. It is also possible that participants "united" by an interest simply did not want to work together. In this case, participants often did not have the resources to follow through. For example, one participant wrote, "While we support the project idea... our organization has a lot on its plate and would rather focus on a few projects to ensure they're done well and avoid getting spread too 
thin..." The findings regarding action plan implementation pose a serious challenge to the Open Space axiom that "whoever comes are the right people" (Bryson \& Anderson, 2000, p.151) and support contentions that at least in some cases "significant follow-up" is required to implement action plans developed in the large group setting (e.g., Bramson \& Buss, 2002; Schafft \& Greenwood, 2003).

Power issues identified with respect to agenda setting (McCullum, Pelletier, Barr, \& Wilkins, 2003; Pelletier, McCullum, Kraak, \& Asher, 2003) were not observed in this case (as evidenced, for example, in survey scores, defined projects and indicators of a healthy regional food system). One possible explanation may be that action planning was conducted using Open Space methods rather than (Future) Search methods: eliminating prioritization of action agendas by the group reduced the potential for some groups' agendas to be left out. A second explanation may relate to the participant profile that in this case included a high degree of agreement regarding social and environmental sustainability objectives, thus likely mediating the potential for dominant conventional discourses to prevail.

Overall, this case supports the assertion that whole systems, constructivist, and participatory design principles, combined with attention to factors shaping learning, contribute to improved individual and system understanding and facilitate individual and collaborative activity that supports movement toward a shared vision or goal. An 
important caveat is made with respect to the action agenda component, with findings from this case consistent with other research indicating implementation of action agenda to be problematic. The holistic perspective to evaluation was important, for while some of the individual Forum components evidenced issues or trade-offs, the Forum overall successfully met design objectives and conference goals.

Units of analysis for this MCLA case include a large group intervention and a collaborative alliance. Having considered how the large group intervention fits with MCLA design theory, attention turns now to the collaborative alliance. As detailed in Chapter Two, this research focuses on the Launch Team/Advisory Board rather than sub-teams or project groups.

\section{Collaborative Alliance}

The recognition that system complexity, plurality, and uncertainty necessitates that multiple stakeholders work together to address social dilemmas has spawned a sub-set of collaboration ${ }^{1314}$ theory commonly referred to as inter-organizational collaboration

\footnotetext{
${ }^{13}$ The term collaboration frequently refers to both a process and a structure, though Gray and Wood (Gray \& Wood, 1991) differentiate the two calling the structure a collaborative alliance. ${ }^{14}$ Such inter-organizational domain alliances or collaborations go by a number of names, including network collaborations, stakeholder networks, multi-, trans-, or supra-organizational collaboration. Their structure may be federative or coalitional (Cummings, 1984; Selsky, 1998).
} 
and social problem-solving (Brown, 1980; Cummings, 1984; Gray, 1985; McCann, 1983; Pasquero, 1991; Trist, 1983). Particularly instructive are McCann's (1983) and Gray's(1985) process models for inter-organizational collaboration addressing domain issues. The models are comprised of three iterative and overlapping phases: problemsetting includes identifying stakeholders and coming to appreciate system interdependence; direction-setting includes development of a shared vision and strategy for the domain; and structuring includes the development of a regulative framework for the domain. ${ }^{15}$ Trist (1983) contributes substantially by identifying the importance of networking, convening, regulation, appreciation, and infrastructure support to domain development. Of additional utility is research pertaining to collaboration effectiveness (e.g., E. R. Alexander, 1993; J. A. Alexander et al., 2003; Bardach, 2001; Barnes, Sullivan, \& Matka, 2004; Benn \& Onyx, 2005; Bentrup, 2001; Foster-Fishman, Berkowitz, Lounsbury, Jacobson, \& Allen, 2001; Himmelman, 1996; Hood, Logsdon, \& Thompson, 1993; Huxham, 1993, 1996; Huxham \& Vangen, 2004; Lasker \& Weiss, 2003; Margerum, 2002; Mattessich \& Monsey, 1992; Rosenthal, 1998; Roussos \& Fawcett, 2000; Selin \& Chevez, 1995; Selin, Schuett, \& Carr, 2000; D. Sink, 1996; D. W. Sink, 1991; Weiss, Anderson, \& Lasker, 2002; Wolff, 2001)

\footnotetext{
${ }^{15}$ There are similarities to Cummings' (1984) three stage model of identification, convention, and organization, though Cummings' work is framed more linearly.
} 
There is no single theory of collaboration (Armisted \& Pettigrew, 2004; Imperial, 2005; Wood \& Gray, 1991). For example, when considering factors influencing collaboration success, Mattessich and Monsey (1992) identify nineteen items grouped into six categories, Rosenthal (1998) suggests fifty items grouped into eight categories and Sink (1991) offers a thirty-five item checklist. Despite this apparent diversity, closer inspection reveals a fair degree of similarity and convergence regarding these models. Based on the inter-organizational collaboration literature and themes identified in this case, seven interrelated factors impacting effectiveness of the multistakeholder collaborative alliance were considered. These interrelated factors include stakeholder participation, vision and direction setting, leadership, power, social capital, resources, and structuring. Communication, conflict, trust, and learning were considered as well, though they are embedded in the other factors (e.g., trust is discussed as part of stakeholder participation and social capital). The concordance between these theoretical factors and this case is considered below, followed by a summary and discussion.

\section{Stakeholder Participation}

Collaboration effectiveness and domain development are significantly influenced by recruitment and retention of appropriate participants (Gray, 1985; Mattessich \& 
Monsey, 1992; Rosenthal, 1998). The very definition of the domain and direction setting is shaped by who participates; there is a reciprocal relationship between membership and how the collaboration unfolds. Further, the collaboration changes as individuals or organizations enter or exit the partnership or alter their role (Calton \& Payne, 2003; El Ansari, Phillips, \& Hammick, 2001; Gray, 1985; Hardy \& Phillips, 1998). Theory suggests participation by the full range of parties that can inform, influence, or be impacted by the collaboration in order to improve understanding of the system, improve buy-in, and build relations.

In this case, engagement by the full range of parties did not occur, raising questions regarding who participated, when, how, and why. As detailed below, there were five main "episodes" where explicit attention was given to identification and recruitment of stakeholders. Each episode is described in turn, with attention given to the ways engagement was impacted by recruitment strategy, clarity of purpose, convener legitimacy, framing, trust, competing demands, organizational support, and comfort with "process work." 
Episode One - The Initial Convening

When convening the initial June 2001 meeting to consider the merits of collaboration on regional food system issues, an inter-organizational collaboration perspective (versus a grass-roots mobilization perspective) served as the framework for recruitment. The organizer focused on identifying organizational representatives from food production, food access, community and economic development, and education sectors. Social networks facilitated identification and recruitment of representatives.

The purpose of the June 2001 meeting was clearly stated (explore merits of collaborative work on regional food system issues), and opportunities for further involvement were delineated so that people knew what they were (or were not) signing up for. The expected outcomes of collaboration were stated as increased knowledge (intellectual capital, better understandings), improved networks (social capital, better bridges and relations), and enhanced resources (fiscal, human, and environmental capital). The convener was likely accorded some legitimacy given her affiliation with the University and work history organizing similar initiatives in other states. 
Episode Two - The Initial Work Group

After the June 2001 meeting a work group formed to define a strategy for working collaboratively and systemically on regional food system issues. The geographic boundaries for the project and the concepts of scale and sustainability were discussed by the group. At the October 2001 meeting a decision was made to focus the initial project boundaries on the Portland metropolitan region, recognizing its ties to other community food systems and being inclusive of Eastern and Southern Oregon producers. ${ }^{16}$ The group clarified that it was not suggesting that all food production and consumption would be locally based and/or small in scale. The draft concept paper at this time included language about market-based change, institutional support, public policy, system-wide change, leadership development, capacity building, and diversity. The concept of sustainability was not defined, though documents referred to economic, environmental, and human or socio-cultural health.

In October 2001 the group noted that there was a deficit of participation from certain populations but decided that the organizations at the table could adequately represent those interests during the initial planning stage and that outreach would occur for the next phase (e.g., farmers not at the table but governmental and non-profit

\footnotetext{
${ }^{16}$ The concept paper language refers to "eaters" in the six county Portland Metropolitan Region and "producers" in Oregon and Washington that serve them.
} 
organizations working with and for farmers being present). One rationale for this decision was respect for people's time (e.g., farmers are busy and may not be able to go to a lot of meetings). Another was the preference by some potential participants to assist with defined projects rather than engage in planning or "process" work. An example of this is reflected in an October 2001 email from a work group member, "I don't think we will get much interest from any of these folks in this planning stage (I've tossed the idea out and gotten 'good idea, let us know when you have something' comments)."

\section{Episode Three - Expanding the Circle}

A major purpose of the April 2002 Forum was to "ground truth" proposed projects and identify potential project collaborators. Thus, Forum recruitment focused on "key stakeholders of influence that need to be at the table as projects in support of regional community food systems are developed and implemented."17 This recruitment strategy applied $t$ beyond the Forum as well (i.e., on-going efforts to recruit participants to project teams after the Forum). In the interest of bringing a whole systems perspective to the room and fostering effective collaborative learning and action, work group members were asked when nominating invitees to think about

\footnotetext{
${ }^{17}$ Language used in emails and meeting minutes.
} 
diversity (e.g., rural-urban, ethnic, age, food system composition) and ability to consider diverse perspectives and work with others. Key stakeholders who had expressed interest in the initiative but were not participating in the work group were also offered the opportunity to suggest invitees. During the Forum recruitment process a missed opportunity occurred when someone contacted a non-CFM conference organizer with an offer to help recruit members of the agricultural industry:

I was told, in essence, that some farmers were coming but that the mix of invitees was carefully chosen and that it was already quite full, so essentially, I needn't trouble myself. I didn't pursue with you or others further because I didn't know which farmers had been invited, and I didn't want the organizer to think I'd gone around him/her.

The non-CFM conference organizer's lack of understanding about CFM's interest in participation of the agricultural sector, coupled with a conflict avoidance strategy on the part of the community member, led to a missed opportunity to utilize social networks for recruiting members of a target audience.

The objectives, activities, and target audience for the Forum were clearly articulated on the invitation (Appendix C). An effort was made to use language that was inclusive and accessible (e.g., the event was titled "Growing a Regional Food Economy: A Forum for Promoting Good Jobs, Food Access, Environmental Stewardship, and Farm Viability"). No Forum fees were charged in order to reduce 
barriers to participation. The primary host, Community Food Matters, was an unknown entity at that time which may have influenced perceived legitimacy (the event was its public launch); however, CFM's charter members were listed on the invitation and included a substantial list of credible institutions representing diverse food system sectors. The event's location (Portland) may have been perceived as too urban for some invitees, and the RSVP address (Ecotrust) may have been perceived as too "environmental."

In hindsight, language used during the recruitment process was sometimes laden with terms potentially unfamiliar or inappropriate to the audience (e.g., social learning, community food system, local food, sustainable). Also, speaking about the Portland Metropolitan Region may have left some target groups feeling left out. Although the CFM group had noted that the project was inclusive of producers in Oregon (later to include Washington State as well), the perception for some was that this was a Portland-focused initiative. This misperception can be seen in one person's comment that "I can't in good conscience support an effort that excludes a farmer just because of where they are farming in the state."

Related to the geography question was the issue of how trade was framed. One interviewee noted that $\mathrm{s} / \mathrm{he}$ and her/his department view wealth creation as coming from primary jobs that bring revenue in from outside the region and how they 
perceived CFM's agenda to be about small-scale and/or local sales- which in their mind does not add up to significant wealth creation.

While I feel that CFM has it's own niche and it's own value, I struggle trying to think about, 'How is this going to help us with that 50,000 jobs? [the Governor's stated job creation goal at the time] How's it going to help with primary jobs?' ... For people like me in the economic development part, we-it's unfair to say that there are bigger fish to fry, but there are other things going on that we want to get involved in and sometimes that can be placed above on peoples' priority of just doing things regionally. I think this adds to some of the complications of getting this kind of thing going.

Even though CFM's concept paper explicitly stated by Autumn 2002 that "trade both imports to satisfy needs and demands and exports of surplus or specialty crops is included," this interviewee noted, "I think ...that the perception is that's somewhat played down...Maybe it is that that message is just not getting through enough. That we gotta still focus that CFM involves trade."

Framing, trust, and perceptions of legitimacy together influenced participation.

Examples of this can be found in the following interview quotes:

There are people from organization $\mathrm{X}$ that are inclined to be distrustful of the motives of CFM. Mostly out of ignorance, but their initial reaction is mistrust. It's not hostile. Board members say [evil voice] 'do they want to tell us how to farm?' ...CFM wants to manipulate the market for food and turn us into, make us all farm organically and circumvent the normal distribution/sales channels.' Things like that. And, 'What do they know about Ag anyway?' It sort of comes down to that. That's a trust issue that CFM needs to be aware and figure out how to address. 
Involving the $\mathrm{X}$ folks is a bit of a trick and I wish I felt more optimistic. The things that we are talking about are over on the edge of many people's (and the institution's) comfort zone.

A group like CFM, especially early on, was almost seen as a threat somehow. I think that it lingers less as it's become a little bit better understood. But lets face it, X just wasn't doing their job...I can't tell you why invitations that were offered weren't accepted. In some ways, the whole system is a bit broke - when you don't have the state institutions - like I represent - more engaged and responsive some how, being at the table with groups like CFM for example. I just shake my head. The system is so out of touch in some ways.

Related to trust, for some, was the issue of turf:

We touched on this some before, I sensed that with some people it goes back to the turf issues. How is this different from what I' $\mathrm{m}$ doing? When there is a similar theme on projects. I've seen that concern.

There were people there trying to figure out, 'is this a threat to what I do?

Institutional climate also influenced individuals' ability and willingness to participate.

Noted interviewees:

The overwhelming sense one gets at $\mathrm{X}$ right now [2002] ...is a huge amount of uncertainty about the budget and very little willingness to commit to anything until things are clearer.

You need to feel safe by having your own organization let you know that it is safe to be part of a collaboration. Safe like what's happening to your work plan, are you giving away secrets, can you take credit if you are now part of a larger group working to advance the same issue. 
Some individuals and organizations had difficulty appreciating the processual and emergent nature of participation. For example:

It's sort of a process that gestates and takes time. But there is, for people that are real action oriented, it's difficult to forecast and see what are the tangible outcomes that will be there at the end.

Right now, just because of the politics around, I'm just a little nervousI mean, it's changing... the pressure for deliverables... that we're gonna be graded on kind of. Does going to a meeting for CFM, where does that fit? Taking the time to do that is kind of like an attorney's billable hours.

Similarly, some participants felt that their home organization did not see the possibilities associated with collaboration. For example:

It's just the weirdest thing. I don't even get it...because even when there's been an opportunity for tangible benefit to them in this collaboration, like getting AmeriCorps interns or help with fundraising-they still don't seem to be on the dime...I think they just don't get it. About what it's value is.

A lot of people in Ag would shy away from a lot of these things [forums to discuss the issues]... It is taking a systems approach to this issue...And that's really worthwhile and I think it's worthwhile to a lot of people in our organization to have that same perspective. We've been fighting here to try to get that [systems perspective]... and it's been kind of an uphill battle, but it's useful.

Episode Four - From Launch Team to Advisory Board

A fourth stakeholder recruitment episode occurred when the Launch Team transitioned to an Advisory Board/Council. In February 2003 extant Launch Team 
members were asked whether their organization would remain on the newly configured Board and whether they could identify any missing organizations given the group's interest in having representation from food production, food access, and community development and public, private, and non-profit entities. Three new members were recruited (representing Oregon Tilth, ${ }^{18}$ Portland State University, and Metro $^{19}$.

By this time some of the earlier questions about boundaries, scale, and "organic" had settled down somewhat and levels of trust from key stakeholders appeared to have increased. However, there was still a lack of participation by some key stakeholders. In part, this represented a lack of resources available for outreach and recruitment. In addition, some individuals' participation was influenced by organizational instability. As one interviewee noted, "We lived through the state funding crisis ...that's kind of the external economic context...I think that creates some underlying tensions for people. [Names five people and organizations from the Core Team]. All of those peoples' jobs have been in jeopardy during this process. All of them."

\footnotetext{
${ }^{18}$ A non-profit sustainable agriculture research, education, and certification organization.

${ }^{19}$ The directly elected regional government agency serving Clackamas, Multnomah, and Washington Counties in Oregon.
} 
Episode Five - Reconfiguring the Advisory Board

The fifth significant recruitment episode occurred in late 2005 and early 2006 when the Advisory Board was being reconfigured. Recruitment was targeted toward organizations representing gaps in the knowledge and network base currently at the table (e.g., health care or food industry). Social networks were utilized in the recruitment process. New organizations participating included PSU's Food Industry Leadership Center ${ }^{20}$, Organically Grown Company ${ }^{21}$, and PSU's Center for Sustainable Principles and Practices ${ }^{22}$, and OSU's Small Farms Program ${ }^{23}$ (filling a position that had been vacant for many years). A health care industry representative expressed willingness to join in a few months, after medical leave. The Oregon Department of Agriculture representatives left the Advisory Board though they expressed willingness to be a resource on specific projects. Four organizations sent new representatives (Oregon Food Bank, Portland Multnomah Food Policy Council, Food Alliance, OSU Food Innovation Center).

\footnotetext{
${ }^{20}$ The Food Industry Leadership Center provides education, leadership and research to students and professionals in the food, beverage, and consumer packaged good industries.

${ }^{21}$ The Pacific Northwest's largest wholesaler of organic produce.

22 The Center for Sustainable Processes and Practices fosters multidisciplinary research focused on strategies and solutions supportive of sustainability. The representative from this organization was a participant of the initial June 2001 convening and served on the Launch Team as a member of another agency.

${ }^{23}$ Part of Oregon State University Extension Service, the Small Farms program provides information to small commercial growers and small acreage landowners. A small farm agent for the metro region contributed significantly to CFM between the initial convening and Forum. His position remained unfilled for a number of years after he moved to another state when potential lay-offs were being discussed due to budget uncertainties.
} 
During this recruitment episode it was noted that the Advisory Board would meet two to three times per year and provide key insights and direction regarding strategy. For new recruits the extant membership, hosting by PSU, increased societal attention to the issue, social networks, clear definition of objectives, and existing track record likely provided a sense of legitimacy. Framing may have improved as well; for example, one new recruit wrote, "I wanted to mention that I and my company applauded your 'regional' focus vs. a 'local' approach. We feel the term regional is much more inclusive and easier to discuss than "'local."'

For Board members exiting or transitioning from their Board role to another staff person there may have been competing demands, a sense of fatigue or loss of legitimacy given the inability to secure resources to implement defined projects, and/or a failure to clearly articulate accomplishments to date.

The reconfigured Advisory Board met once, in March 2006, with the focus of the meeting being the regional food system assessment effort - one of the priority projects identified in 2001. A number of additional parties were invited to attend the meeting given their interest in regional food system assessment work. This included representatives from PSU's Institute for Portland Metropolitan Studies, Ecotrust, OSU/ODA Food Innovation Center, and OSU's Horticulture Department. The 
meeting was productive; however, the assessment process and CFM were tabled due to a lack of funding.

\section{Summary Of Stakeholder Participation}

Recruitment in this case focused on organizational representatives rather than "citizen activists." The effort was successful in recruiting to the Launch/Advisory Team a range of stakeholders representing the focus areas of food production, food access, food system education, and community and economic development. As one interviewee noted, "I think you've done a really diligent job of trying to identify what the key groups are to have at the table." At the same time, private sector, and low and minority income populations were not adequately involved. Questions also emerged regarding whether some of the participants were fully empowered to represent their organization.

On a few occasions it was acknowledged that additional outreach and recruitment efforts should be made, however resources (i.e., time and travel funds) were not in place to do so. Further, although the process was designed so that members would draw on their networks, norms, and trust to recruit others, in reality this did not always occur - whether the members did not make the effort, tried and were unsuccessful, or both. Further, geographic proximity proved to be an issue (Gray, 1985; Huxham \& 
Vangen, 2000a), with participation heavily favoring the City of Portland and Multnomah County.

Slocum (2006) critiques the community food security movement for being too White and middle class and suggests that the movement is unable and/or unwilling to confront its racist and privileged positions. This may be so, but other factors may be at work. Participants at the table may have lacked the social capital to effectively engage others and/or may failed to frame the invitation in a manner that resonated with the target population. As one interviewee noted, "just by inviting people in to be part of the process isn't going get...people in." Noted another:

I think we're still struggling to have the voice of more mainstream and commercial Agriculture heard, but also just understood... But that's not through any- it's certainly not through any failure of um...process. To the extent that it hasn't happened, we haven't figured out a way to make it happen...I think we're all at a loss for how to make it happen.

As Schafft (2003) found, "circumscribed networks" make it difficult to recruit participants, even when efforts are made.

As evidenced in this case, and in the literature, a number of factors influence participation by the full range of system stakeholders that may inform, influence, or be impacted by a collaboration. Trust, perceived legitimacy, framing, organizational support, and competing demands influence motives, timing, and type of participation (e.g., Everett \& Jamal, 2004; Gray, 1985; Lasker \& Weiss, 2003; Margerum, 1999; 
Ospina \& Saz-Carranza, 2005; Powell, Koput, White, \& Owen-Smith, 2005; Schafft \& Greenwood, 2003; Vangen \& Huxham, 2003b). Stakeholder diversity, and attendant diversity of frames and motives, influences development of a vision for the domain and the collaboration - the topic to which we next turn.

\section{Vision and Direction-Setting}

Presence of a shared vision is suggested as important to collaboration success (J. A. Alexander, Comfort, Weiner, \& Bogue, 2001; J. A. Alexander et al., 2003; Gray, 1985; Mattessich \& Monsey, 1992; McCann, 1983; Rosenthal, 1998). This includes a vision for the future of the domain as well as a vision for the collaborative alliance's role in achieving that state. McCann (1983) uses the term "direction-setting" to describe the process of identifying a preferred future (how we want the domain to be) and agenda (what we should individually and collectively do). Drawing primarily on Alexander (2001; , 2003), McCann (1983), and Mattessich and Monsey(1992), this section considers envisioned future (desired end state), organizational identity (values and function), organizational focus (shared vision for what should be done), and presence of a systems perspective (as part of the vision). 
When asked what would be different if Community Food Matters is successful, interviewees paint a picture that includes more local ownership and viability of small and medium scale farmers (10 respondents), a population that understands and supports local/regional food systems (7), and more integrated, systems thinking and collaboration (7). A small sub-set of interviewees included access to nutritious, culturally appropriate, and sustainably produced foods in their unprompted definition (4). Similarly, responses regarding the question of what a sustainable community food system is point to the economic, environment, and equity dimensions common to sustainability definitions, though there are variations on the theme and a few responses that focus exclusively on economic viability of farm businesses. For example:

I would say a sustainable community food system is one that can perpetuate itself without being a negative- what are the right words doesn't degrade the environment, honors and respects the people that work in the food system and ensures the long term economic viability of those who work in the food system. And provides healthy and safe food to all those who need it.

I think it's a food system that...offers various elements that result in a thriving Agriculture- statewide; in the foreseeable future and forever. That $\mathrm{Ag}$ regardless of size, regardless of commodity would stay viable. It'd be around to do business... and that would include being reactive to, really pro-active and strategic about the marketplace. You know, "What does the marketplace want? Okay, if that's what they want then that's what we need to grow and that's how we need to grow it."

That's a big one because what it would do would be to give several things. And one is meaningful employment at all levels from labor 
through um management...there would be ways for people to get into farming, ways for people to get into distribution and also into preservation of food or secondary products related to foods. The thing is that we'd have an education so that people growing up would understand where food comes from-whether its plants or animals or animal products... And the appropriate place in our lives for food ... the by-products and waste products would be recycled back into the system in a very effective way. We wouldn't actually have waste ... we wouldn't have synthetic pesticides, that we'd be able to do everything organically... There's probably more. I also am trying to include the fishers in this too...

It's a lot different from what we have now! Several things. One is ... those who produce food would be basically stewarding resources and see themselves as being in a role of enhancing the environment and see themselves connected with the natural resources that they're using. And that it would- that going into food production and processing would be considered an exciting profession for young people. That it would have a lot of 'cache'. And there'd be a lot of opportunities for success for producers in terms of market outlets of all different kinds... and widespread knowledge being disseminated about how to grow your own food and access to land for urbanites... Well, in a sustainable community food system people wouldn't go hungry. And food...would be seen as ... one of the responsibilities of government. Just as they see themselves as having some responsibilities for providing, you know... affordable housing. They would undertake responsibility to provide affordable food.

One which is able to be maintained for seven generations. One that has life and spirit. One that recognizes the inherent inequities within the current dominant food production and distribution system. And it wants to make a difference in producing foods more organically, with fewer chemicals. Not necessarily a totally organic system. And it has justice for all involved- air, land, soils, water, farm workers, farmers, distribution people, marketing people and customers or citizen eaters.

Noted one interviewee:

There certainly are people in that room with very different values and some people are involved in the food system in a way that is different than the vision of other people in the room, [but at the same time], we 
all have certain bedrock values, we all want to see things improve in terms of hunger and health and smaller businesses getting a fair shake. There are some basic values that we all hold in common and I think people have a lot of hope that maybe this is an avenue for change.

Said another interviewee:

If we as individuals were being represented as a Venn diagram, we had lots of overlap in where we were coming from in terms of our organizations or the work that we did or the things that we believed in. And where we did not overlap, people were comfortable with whoever was there. It's kind of amazing that $\mathrm{X}$ and $\mathrm{Y}$ were at the same table. But, both having recognized that they have a lot in common was a very important step. I think that's probably why there is less friction or whatever because everyone's agreed on the common goal so fully. And it's a big enough common goal that everyone can get their arms around it and just deal with that. And then go do their own thing later somewhere else.

These statements, coupled with consensus about the mission and draft sustainable

regional food system objectives, indicate that there was general agreement about an envisioned future.

\section{Organizational Identity}

Interviewees were asked "If someone were to ask you 'what is Community Food Matters?' what would you say?" Sample responses include:

It is a collaboration of organizations and individuals, representing nonprofits, government organizations, businesses (private), that have come together to address food systems issues in the Portland Metro region. Which encompasses now, I think, six counties. The goal is to build a regional food economy.

It's a collaborative initiative to improve food security in the Portland foodshed. 
I say it's a group of food activists from a cross section of public, private and non-profit sectors that have come together to do some work on building food systems in the area.

I would say it's a coalition of organizations and governmental agencies that are coming together to network and learn from each other and to see where the potential might be for joint projects and develop the relationships necessary to move those projects forward.

Overall, interviewees viewed CFM as a collaborative alliance (group, network, coalition) with diverse members who address food system issues (through learning, networking and/or projects) in the metro area/region. No respondent included the mission or objectives in their definition. Common themes regarding the vision or definition of CFM appear, though distinctly different terms are used: for example, food economy versus food security. The degree to which respondents are using different phrases similarly and/or hold different visions of the organization is not clear.

Organizational Focus

While there was a common vision for the future of the domain and alliance mission, there was not agreement regarding how best to achieve these goals. A significant direction-setting dilemma emerged in the question of whether CFM should undertake projects. 
Initially, the collaborative alliance was designed to include a portfolio of projects that, together, would provide an integrated response to promoting regional food system sustainability. It was thought that a whole systems approach involving diverse system stakeholders would be more likely to effectuate positive change than current piecemeal efforts.

In October 2001 concerns were expressed that it might be premature to begin focusing on projects, and the suggestion was made that defining a healthy community food system and assessing the region's food system would be important first steps. The work group agreed that development of such shared understandings was important but should be integrated into the portfolio of projects rather than preceding them. The decision to focus on projects was based on profiles of other regional food system efforts, preferences articulated at the June 2001 meeting, and the Kellogg Foundation's funding priorities. However, by late 2002 there were signs that support for at least some of projects might be waning; some designated leads were not leading, work plans and budgets were not completed, and teams were not effectively pursuing additional funds.

In October 2003 the Advisory Board clarified its belief that CFM plays two critical capacity-building roles: 1) provide real and virtual spaces where diverse members of the food system can network, share information, and learn about key issues facing the 
food system and 2) collect, analyze, and disseminate comprehensive, meaningful information about the state of the region's food system. There was less agreement about CFM's role with respect to projects. A number of reasons for including projects were offered. It was thought that projects could help "sell" the initiative; that is, while capacity building was seen as vital, it was believed that many constituents and funders have trouble understanding the value of capacity-building and want to see something more "tangible." Also, a portfolio of projects was seen as addressing interest in collaborative and systemic approaches to promoting a sustainable regional food system. Finally, some individuals felt a responsibility to honor the process to date (e.g., check-ins with the community and effort expended thus far). At the October 2003 Advisory Board meeting there seemed to be strong agreement for eliminating the portfolio of projects and focusing on the capacity-building initiatives. However, as ten of the eighteen Board members were absent from this discussion, a summary of the conversation and request for input was conducted by email. Following the email discussion a decision was made to retain the portfolio of projects. The issue of projects was revisited at the May 2004 Board meeting. The group again defined networking and information dissemination as the best value-added products that CFM provides. Ultimately the final Concept Paper, endorsed by the full Board, included the portfolio of projects. 
The confusion regarding whether or how to engage in projects is revealed in the interviews. For example some interviewees believed that CFM should not engage in projects (other than "capacity building" initiatives):

I guess I still feel confusion over whether or not CFM should have projects or whether it should be network and learning; because I think that's what it does best...

I think the mature CFM, five years from now, CFM won't own anything except the State of the Regional Food System. As something comes up it will be very clear, 'Oh that's W's project. W, how can we help you grow that project?' It never was a CFM project. Or at some meeting someone says, 'My problem is this. Can Y take that on?' ... There isn't a CFM 'ownership.' In fact the strength of the ownership comes from all those other organizations owning the projects.

Others felt that some sorts of projects, even if more modest, were important for

building visibility, legitimacy, and support:

I guess I'm thinking of something that is outward directed. It's demonstrative like, just tiny but symbolic things that CFM could do and pull off and take credit for that would establish it as an important force in the food system. It's only a tiny piece of what we conceive of as our larger mission but it has large symbolic value. And it's something we can say to the larger community that doesn't get up in the morning to think about these things, "Wow. CFM, well they did a cool thing! Who the hell are they? Let's find out more about them. Maybe I wanna join and volunteer some time to help them." That's the movement building part that I'm referring to.

While in hindsight it might seem clear that a "portfolio of projects" should not have been included in CFM's work plan, questions of whether and how to engage in projects are common in collaboration. On one hand, it is suggested that early wins (Bernard \& Armstrong, 1998), "short-term, sometimes symbolic, achievements" (J. A. 
Alexander et al., 2003, p.135), and a focus on problem-solving over networking (Potapchuk, 1998) can be important for collaboration success. Other research suggests that program delivery is less effective and collaborations should best be viewed as mediating social structures (e.g., Chavis, 2001).

Summary of Vision and Direction Setting

The Launch Team/Advisory Board members held a good deal of agreement regarding the preferred future for the domain (envisioned future) and the purpose of the alliance (ideological vision). Ambiguity regarding envisioned future was facilitative, while ambiguity regarding the ideological vision (organizational focus) was problematic. Direction setting faltered without the articulation of an appropriate agenda for achieving the vision. This outcome is related to another factor important to collaboration effectiveness - that of leadership - which is considered in the following section.

Leadership

Identified as key to collaboration success (J. A. Alexander, Comfort, Weiner, \& Bogue, 2001; Crosby \& Bryson, 2005; Huxham \& Vangen, 2000b; Turning Point 
Leadership Development National Excellence Collaborative, 2001), leadership ${ }^{24}$ in this context refers to formal (positional) leaders and informal leaders who are able to "make things happen" (Huxham \& Vangen, 2000b) in a collaborative setting. Four interrelated themes important to understanding leadership in interorganizational collaboration are considered here: collaborative competence, facilitative processes, collaboration managers, and partnership representatives.

\section{Collaborative Competence ${ }^{25}$}

Collaborative competence is defined here as skills and attitudes that are important for individuals and organizations to effectively work together (J. A. Alexander et al., 2003; Barnes, Sullivan, \& Matka, 2004; Brooks, Bujak, Champ, \& Williams, 2006; Foster-Fishman, Berkowitz, Lounsbury, Jacobson, \& Allen, 2001; Selin \& Chevez, 1995). As one interviewee noted, "Collaboration is not something that everybody does easily." Collaborative competencies considered here include presence of a systems view, collaborative perspective, and productive conflict management.

\footnotetext{
${ }^{24}$ The terms leader, manager, and facilitator are used variously in the literature and sometimes interchangeably. Typically, a manager is defined as someone who has responsibility for coordinating people and projects to deliver a product or service and a facilitator as someone who assists in guiding a process. A leader may be someone in a position of formal authority (including as a manager or facilitator) or someone who informally inspires and enables people. ${ }^{25}$ The phrase collaborative competence is used rather than collaborative capacity as some definitions of collaborative capacity include attributes such as resources or vision, which are considered elsewhere this document.
} 


\section{- Systems View}

An important leadership attribute in interorganizational domains is appreciation of the systems nature of the issue (J. A. Alexander, Comfort, Weiner, \& Bogue, 2001). Observed one interviewee, "Some just connect the dots better." As noted above, overall, Launch Team/Advisory Board members held a systemic perspective on the issue. At the same time, obstacles to a systems perspective were identified. One obstacle was a lack of systems appreciation by some participants' home organizations.

As one interviewee noted:

The best way to get from point $A$ to point $B$ is not necessarily a straight line but it involves a process; it involves networking with people, associating with people, listening to other points of view and incorporating those in what you finally end up with. That's kind of at the heart of it. We've been talking about this around here [his/her organization] at length and it's kind of a hard one to get through to people...

Related to this were mandates to be "focused" and produce tangible results. As one interviewee noted:

When resources are less, people like myself are being asked to be very focused. In my job, it does, it cuts down on the time and attention I can pay to collaborative efforts. But when those collaborative efforts are very focused and strategic then- well... I probably have less time to spend in sort of broad discussions, but it's in my interest to spend scarce time working with [for example] $\mathrm{X}$ on building something where shared resources benefit both of us. And they get a better product and we get something that meets the needs of our constituency faster than we would've and for less resource dollars. 
Another obstacle to the systems approach was the common collaboration dilemma of integration and differentiation or unique purpose (Eden \& Huxham, 2001; Mattessich \& Monsey, 1992; Takahashi \& Smutny, 2001). This dilemma occurs as organizational partners struggle to maintain their unique identity and purpose while also working with others to advance interests. Related to this is the challenge member representatives face managing fidelity to both their home organization and the collaboration. As one interviewee noted:

I think part of the challenge in a process like this, which goes back somewhat to trust and turf issues, is who people are accountable to...There's that on-going tension between 'I' $m$ an employee of $x$ but now I have responsibilities not just related to my interest as an employee of $x$ but also my responsibility to this group as a whole ...' I think it's a good thing because it helps people get outside of their own narrow focus but it's a challenge.

Noted another:

You know, I love the idea of collaboration and systems... And I know that's the way it has to be ...But one of the things that so hard for people, not for myself in particular, but for my organization is that, people [organizations] need reasons to exist and unless they can show that they've done something to make a difference, their funding will get cut. And so, in terms of collaborative projects... it would not be looked upon favorably if I did a project and wasn't either the lead organization or THE org. And I don't really like that, but I can understand that...So, I think that's a huge challenge.

Ideally, a systems view prevails such that an organization and its members reframe or expand their self-interest to include larger community goals, are able to see how 
collaborative goals are consistent with or supportive of organizational goals, and are able to find ways to get "credit" when working collaboratively - though clearly this is not always the case.

As McCann (1983) notes it can be difficult to maintain a systems perspective; efforts to remind members about the vision and its systemic nature may be required. Noted one interviewee:

Just constantly being clear because this is a process with a lot of subtlety and it is a relatively slow process... to communicate with as much clarity as possible what the objectives are because it is so big. It can seem so amorphous that we need to create these little pathways of clarity... What it is or how it has value and it's almost as if- and again that's kind of a message that needs to be repeated because of it's largeness it can be a little discouraging if people feel like they're not sure where they're going, where it's leading and whether it's a good investment of time."

- Collaborative Perspective

Collaborative perspective is an important platform for leadership in collaboration.

Such a perspective acknowledges that collaboration, at least in the given circumstance, is a valuable thing to do. Exemplifying such a perspective one interviewee remarked:

I really believe in collaboration. I feel like it's not even- for me it feels not an 'option.' It feels like the way; the only way to do things... I feel like there's so many examples of where so much more synergy is created when people work together that I think that that is the way for us to be the most effective. 
While a collaborative perspective can be cultivated, clearly some individuals have a better baseline understanding of the value of collaboration and comfort with the process. As noted in the interviews:

Collaboration is not something that everybody does easily.

Some people just are not conducive to leadership roles or collaboration in general; they just have a hard sharing information and resources and time.

It's a slow process [collaboration]. And it may be too slow for some people. Some people can't tolerate that at all... X was more involved with CFM than I was at the beginning... and he was sort of like, 'Oh I can't tell what's happening and I don't know anything.'...But the first meeting that I went to, I was really blown away. Just in terms of - I thought a lot happened. I saw a lot of engagement, a lot of learning, a lot of potential. It felt like...it's all a matter of perspective.

Someone with a collaborative perspective understands the give and take required in collaboration. Noted one interviewee, "That's how you have to work in a collaborative. Sometimes it goes exactly your way and sometimes you just have to roll with it even though some piece of it [what you wanted] is not a part of it." Noted another, "Realizing that collaborative- anything collaborative means working together. It means listening to other peoples' ideas as well as articulating your own... You need to understand that you're going to be pushed out of your comfort zone...Realizing in the collaborative process, your thinking is going to change." 
An absence of collaborative spirit or perspective does not necessarily flow from malicious intentions but may be related to very rational organizational interests; for example, the need to take credit, acquire resources, or ensure that "turf" is not being encroached upon. As one interviewee noted, the mandate from his/her organization was that:

There needs to be ...money that funnels directly into this operation so that it shows tangible accomplishments. That's one of those things where you wish it didn't have to be that way but it is. Because a lot of people in Ag are very bottom line...bottom line. You know, 'I don't want to look at this vision, I just want to see okay, what's this doing for us?'

Noted another interviewee, participants need "to feel safe...perhaps by articulating that it (CFM) is committed to not replacing or competing but to address issues that tend to fall through the cracks unless you have a collaborative like this..." Also, a decision to act without collaboration partners may be a sign of collaborative knowhow as much as a lack of collaborative perspective (i.e., understanding where, when, and with whom to collaborate in order to maximize collaborative advantage) (Simonin, 1997). However, decisions to work without collaboration partners need to be communicated clearly; failure to do so may create trust issues. For example, one interviewee noted, "I have noticed an organization that seems to really look out for itself ... I don't know if I'd say I don't trust them, but it is just that I'm glad that I know that because it does change the way that I would interact with them... If they can apply for a grant on their own they'll do it and not necessarily be collaborative 
about it." While organizations need to be strategic, leadership regarding such

decisions can facilitate trust and relationship building integral to collaboration success.

In this case, the collaborative perspective among the Launch Team/Advisory Members was quite strong, as described by this interviewee:

People seem to be respectful of other people's opinions...And they're putting a lot of themselves into it too; to bring about positive results. Sort of suspending judgments at times. ... What I'm going back to is my experiences especially at earlier meetings that, 'Oh, this is different than other things that I've been involved with.' And the way in which it seemed to be different was in the sense of commitment that people had to the whole endeavor as opposed to coming to a meeting and representing your own agenda with these other people and trying to figure out how to get your agenda; stick your agenda into what's happening...Oh, there's certainly some agenda stuff! But, I think people... they're not- at least I haven't seen, people pushing their agenda to the harm of the larger cause.

\section{- Productive Conflict Management}

Eden and Huxham (2001) note that "most collaborative groups involving multiple stakeholders and concerned with complex social issues exhibit many areas of tension [and w]hat distinguishes those that work well is the group members' capacity to manage the tensions" (p. 385). Noted one interviewee, "There's a general level of tension sometimes. That is not necessarily unhealthy either. How you act upon or react to those tensions is what can get ugly you know... No. I don't think I've felt that ["unhealthy" or "showstopper" conflict] with CFM." 
Observed another interviewee, "Sometimes I feel we've had to avoid really sticky issues in the interest of just moving along or getting something done. You don't really want to get bogged down in this whole conversation about conventional/chemical Ag versus small organic. And I feel that's fine. You can't force the dialogue to happen all the time and you need to have motion and progress to keep people involved." In this case, participants mostly found a way to navigate conflict and continue working together. This included "agreeing to disagree" on some issues, respecting differences, and maintaining cooperative working relationships (Imperial, 2005, p. 308).

Consistent with other research, overt conflict was found to be the exception rather than the rule in this case, with a "get along" norm prevailing (Clarke, 2005; Everett \& Jamal, 2004; McCullum, Pelletier, Barr, \& Wilkins, 2003; Poncelet, 2001a; Schafft \& Greenwood, 2003; Turcotte \& Pasquero, 2001). Potential explanations for this practice include participants' conceptualization of collaboration as non-conflictual in nature, a shared dominant discourse about the issue, desire to maintain respect and access in the interest of goal attainment, efforts to attend to organizational maintenance, and discomfort with difference and conflict (Martin, 2000; Poncelet, 2001a). In some instances such conflict avoidance was a productive strategy for moving forward (collaborative competence). In others, such conflict "management" meant missed opportunities for transformative or functional conflict that could make 
the collaboration stronger; for example, by creating a space for open examination of an issue that leads to increased understanding, improved relations, and/or better collaborative skills (Chavis, 2001; Dukes, 1996; Eshuis \& Stuiver, 2005; Marsick \& Kasl, 1997; van Rossum \& Sole, 2006).

- Facilitative Processes

Efforts were made to facilitate leadership and collaborative competence. These efforts included fostering a tone of respect and appreciation, systems thinking, fair and democratic participation, and open communication supportive of trust building and system understanding.

Examples of how respectful interaction and relationship building were experienced by the group include the following:

I really think that you're doing a great job- and I appreciate it - of being as positive and free of value judgments as possible as you go along. So that...I feel that it is modeling for me how to hear a different point of view on things that I feel passionately about without becoming defensive or putting up a wall...just kind of listening and thinking "you know, I have something to learn from this person." "

There's been encouraged an attitude of respect and appreciation. Generally, I think we've done a pretty good job of listening to each other and acknowledging; showing appreciation. At the same time...it's been okay to have some fun, to have some laughs, to keep the human side there so it doesn't just feel like another meeting. And 
so that we do build personal connections which ultimately are at the root of other connections which are gonna be longstanding I think.

...Time has been created for that (relationship building). It's just so important. Building trust, understanding each other in order to go forward. So, I've appreciated the opportunity to do that with CFM.

With respect to systems thinking, noted one interviewee:

I really do have the sense that CFM has kind of loosened up that thinking and that people are thinking more about 'how can I contribute to a comprehensive approach.' And I don't think that's usual. I think that's the primary benefit that I've seen.

Interviewees also observed that the goal of being participatory, fair, and democratic was being met "extremely well." Said one participant, "I feel like I have had more opportunities to participate and shape the direction and emphasis than I've been able to take advantage of. It's been very open, very transparent." Said another, "I think it is certainly democratic and consensus oriented at the launch team level. I'd be surprised if someone thought differently." A number of interviewees felt that the effort to be democratic and fair occurred "almost to a fault" or "almost too well." These participants felt that sometimes they just wanted a decision to be made. As one interviewee noted:

I do CFM in my spare time. And that's been the hardest thing for me. I think that's true of a lot of other people...I guess I would like the buyin, the consensus thing if we were all full-time working together, focused on this. It would make sense to me to have more of a decentralized piece. It has something to do with the nature of the time commitment that makes me want the other [one person leading] because it feels more efficient. 
Observed another:

It's interesting though because I've sensed from the group-sometimes it's almost like maybe we're just used to such hierarchy. What's the opposite of democracy? I don't know, but I've sensed that people in the group have sometimes wanted you to just like, 'Oh, just make the decision.' But then of course if you do that, there's gonna be somebody that says, 'Wait a minute I didn't get to be part of that.' I admire the way that you've balanced that and really tried to maintain it being democratic and participatory. I think that people aren't used to that. It may be that maybe there's a little more education needed around what that looks like and what the real benefits are of it.

Related to the effort to be participatory, fair, and democratic were efforts to promote good communication. Communication, both listening and sharing, is an essential collaborative competence. Effective communication is important for fostering trust among participants and ensuring the flow of information that supports system understanding and collaboration. Efforts were made to facilitate open, transparent communication and full participation. These communication efforts presented a challenge as participants then had to navigate additional information in an already busy schedule. Said one interviewee, "I guess for me, one of the frustrations I've had is...getting these...emails... and I just don't have time for this right now. And I know that's been very challenging for you too. Because I'm sure I'm not the only person who ignores it until the last second." Indeed, participant observer notes identify feelings of "cajoling, wrangling, sheparding, and babysitting" not unlike the sense of 
"badgering" identified as common to collaboration managers (Huxham \& Vangen,

2000b, p. 1171). Observed one interviewee:

It's less about you than about how people cram their lives with things... You can send out things ahead of the meeting and the reality is that half or more won't read it because of how they have to parse their time.

I think the communication is probably always going to be challenging. Like when you put out an email to everyone and you don't get responses back...I have had the same experience. Trying to figure out: peoples' time is valuable so how do you make the best use of it. So you don't want to over communicate with people, but if you don't over communicate you'll be accused of under communicating and leaving people out of the loop; so balancing that seems like one of the trickiest things in a collaboration.

Additional obstacles to messages being sent, heard, or responded to may have included attempts to protect turf, lack of a systems view or collaborative perspective, overburdened resources, a lack of investment in or engagement with some or all of the agenda, or a mix of these.

During the interview process a few examples were given where people said they felt out of the loop, did not know how a decision was made, or thought certain voices were favored. Further probed, the misunderstandings were traced to a lack of reading or hearing messages coupled with a (conflict avoidance) decision to not raise the question, thus demonstrating an integral link between facilitative processes and leadership competencies. 
Overall, processes to facilitate leadership and collaborative competence were helpful, but not without challenges. Participants appreciated having the space to get to know others in an environment that fostered respectful listening and relationship building. Participants also felt that the process was highly democratic, almost too much so given the amount of time they could commit.

\section{- Collaboration Manager}

Technically, collaboration managers are resources for, and report to, the collaborative alliance; however, it is not unusual for the manager to also be an initiator or catalyst for the collaboration (Hemmati, 2002; Warner, 2005; Westley \& Vredenburg, 1997). Interviewees suggested that the initial convener and manager in this case played such a key role. ${ }^{26}$ For example, "I think that you [Janet] certainly have played the critical role here. The fact that you existed to vocalize it." Interviewees identified manager leadership in boundary spanning and development of domain appreciation, as well as facilitation of collaborative competencies - leadership characteristics identified as

\footnotetext{
${ }^{26}$ As noted in Chapter Three, the convener/manager is the researcher in this case. In an effort to encourage full disclosure, interviewees were reminded that they should feel free to say things that critique the process in general, or the manager in particular. Interviewees were also provided with a blank sheet of paper and an addressed, stamped envelope should they want to provide input anonymously.
} 
important in the literature (e.g., J. A. Alexander, Comfort, Weiner, \& Bogue, 2001;

Huxham \& Vangen, 2000b; Trist, 1983). For example:

For something that is this complicated or that has this many moving parts, to work effectively you need somebody - at least to begin with you need somebody as the point person. Because people don't walk into the room understanding their relationships with each other. It was critical to have you basically helping bring people to the point that they had shared enough information about their issues and their work to see where the commonalities were.

I think it's very important to not discount the level of leadership that you brought. And vision that you brought to the project. Just the willingness on your part to digest the activities and ... of making sure that everybody was in touch with the substance of what we were discussing and considering was of great importance. Your sense that the whole was going to be greater than the sum of its parts ...you haven't been building an organization, you've been building a commitment on the part of a number of organizations to identify among themselves certain shared agendas and move forward to achieve them.

It's a tricky balance because in order for it to be collaborative it really has to be this shared vision thing. But, you also need someone who's willing to really put the time in and manage all of the little details...that go into communication and coordination for a group of people that large.

At the same time, interviewees noted, and expressed concern about, excessive dependence of the collaboration on one person. For example:

The degree to which you have time and energy to put into it is the degree to which it moves forward.

If you're gonna be the piece of string that holds everybody together, what's gonna happen when you move? When someone actually offers you a full-time job with benefits? Is everything gonna fall apart? 
I think we may have left too much to you Janet (pause) and whether that is the failure of a leadership team or your strong sense of what needed to be... or both.

This is not an uncommon dilemma in collaborations; partnership managers often exert a great deal of influence given the understanding of and commitment to the partnership associated with their high degree of involvement (Huxham \& Vangen, 2000 b, p. 1168). Further, this case exhibited the oft-noted tension regarding staffpartner balance - ensuring that things get done can "enable" others to abdicate their responsibilities and leadership (J. A. Alexander et al., 2003). Noted another interviewee:

I think the challenge is it is easier for people to not take responsibility for things when you know there is somebody else leading the charge. I think the tension is how do you make sure that things keep rolling without everything ending up on your shoulders.

Reflecting as a participant observer, it appears that, consistent with the literature, the convener/manager played a key boundary spanning, system appreciation, and vision setting role. However, personality characteristics that were an asset in some instances (e.g., energy, persuasiveness, determination) may have been a liability in others. First, the convener's sense of commitment to the portfolio of projects inhibited her ability to "learn" that this was an inappropriate direction and, thus, change course. Second, the convener's sense of the group's strong collaborative competence and collegiality blinded her to the potential for unproductive conflict avoidance behaviors and/or feelings of disempowerment, alienation, or silencing. Third, despite taking measures 
to foster a participatory, open climate, the fact that the project was so identified with the manager may have contributed to some participants assuming a more passive role.

- Partnership Representatives

Partnership representatives, the organizational delegates to a collaborative alliance, are positional leaders with an important role to play. Ideally, these individuals serve as conduits of information between the home organization and collaborative alliance and draw on their and their organization's unique skills and resources to steer the collaboration to success (J. A. Alexander, Comfort, Weiner, \& Bogue, 2001; Huxham \& Vangen, 2000b). In reality a number of interacting factors affect the actualization of this leadership capacity including institutional support, resources, and clarity of roles.

Obviously, it is difficult to provide leadership to the collaboration when support from the home organization is lacking. Noted one interviewee, "I think there's a real value to the process of creating a group that can collaborate but it can be hard to easily justify in a lot of institutional settings spending the time on the process...often there aren't the incentives in place for people to spend the time and do that [collaborate]." In at least a few instances, the representative appeared to be participating more as a permitted add-on to their work as opposed to a core function of their work - 
sometimes securing permission to participate against protest or caution. Further, when the organizational representative left (e.g. moved away) a new representative often was not assigned. In this case, it does not appear that all of the organizations represented on the Launch Team/Advisory Board were fully vested in the collaboration - whether due to poor leadership by the representative in acting as a conduit, lack of organizational understanding about or valuing of the collaboration work (e.g., concerns about turf or redundancy), and/or self-identified organizational role (e.g. monitor, provide advice, further home organization's objectives).

Launch Team/Advisory Board members did bring institutional resources to bear in support of the collaboration (e.g., cost sharing for events, graphic design assistance, and meeting space), but failed to secure resources for maintaining the collaboration; at no time were partnership funds provided for core collaboration staff and operations. Though as Huxham and Vangen (2000b) note, representatives should be acting as "conduits to the resources of their organizations... it can be difficult to tap this resource" (p. 1170). One reason for this failure was the context of budget scarcity. Another reason may be ambiguity regarding the nature of the collaboration. While the intent was for CFM to be a collaborative alliance of partner organizations, the perception/reality was that it was an organization with advisor-collaborators. At the May 2004 Board Retreat some members noted that framing the collaboration as a coalition rather than its own organization would make it easier for them to participate: 
A coalition model seemed to better preserve their own organization's autonomy and identity, thus making requests easier to "sell" to their supervisors. As one meeting participant noted, "For example, saying 'the coalition wants $\mathrm{x}$ ' - I can respond to that... versus 'I need to raise money [for an organization]." Further, there appeared to be ambiguity regarding the nature of the representative role, including a lack of clarity regarding responsibilities for fundraising. Thus, ambiguity regarding structure and roles impacted sense of ownership and ability to secure resources.

\section{Summary of Leadership}

In this case, as with many interorganizational collaborations, there was a key leader who was integral to formation and management of the collaboration and a "leadership team" comprised of representatives of organizations participating in the collaborative alliance. Basic collaborative competencies and processes facilitative of leadership were in place. Levels of conflict were low and conflict that did appear was successfully navigated, though often a conflict avoidance strategy was employed that decreased opportunities for productive learning and engagement. Despite having many important leadership assets (e.g., competencies, processes, and participants) the leaders failed to steer the collaboration to success as measured by goal attainment or collaborative alliance sustainability. A number of interrelated factors played an important role in this leadership gap. 
First, the roles and responsibilities of partner organizations were not adequately articulated, though it is not clear why this is the case. This ambiguity left leaders lacking a clear directive and also left representatives in a weak position with which to state the benefits of involvement and secure organizational commitments. Second, as often occurs, the collaboration manager took on many of the essential championing and leadership roles, evidencing a tension between the benefits of having a collaboration manager or staff and a reduction in leadership by others that may occur when such resources are in place. (Vangen \& Huxham, 2003a, p. 74). Research indicates that "unstaffed coalitions are less able to produce as many results as staffed coalitions" (Wolff, 2001, p. 178). While there was a part-time manager and some supplemental staff the resources were not adequate to the task. Third, the collaboration manager's emphasis on a facilitative, process-oriented leadership style (J. A. Alexander, Comfort, Weiner, \& Bogue, 2001; Huxham \& Vangen, 2000b) sometimes did not fit well with participants' time constraints and competing demands. There was a tension between the desire to "lead in a facilitative and supportive manner" and the "pragmatics" of "directive" leadership (Vangen \& Huxham, 2003a, p. 72).

In this case, while the collaboration manager was key to collaboration success, an overdependence on the collaboration manager was fostered, particularly given the 
ambiguity of roles, competing demands on participants' time, and the manager's willingness to support the alliance even at great personal cost (Hemmati, 2002; Huxham \& Vangen, 2000a). Ultimately, while Launch Team/Advisory Board participants supported the vision they were not able and/or willing to steer the collaboration successfully - whether they did not see it as their role, or did not have the resources and/or institutional support.

\section{Power}

Power, though multidimensional and variously defined, generally refers to an ability to do or influence (Everett \& Jamal, 2004; Lewicki, Litterer, Minton, \& Saunders, 1994). Power plays an important role in collaboration, shaping whose voice is heard and what agenda moves forward. Power is considered in this case by examining perceptions of power imbalances and prioritization of agendas.

Perceptions of Power Imbalances

When asked, most interviewees said they thought there weren't power imbalances in CFM. There was a general perception that the process was inclusive and that people were equally heard. For example: 
What I've seen and experienced is that this is a very inclusive effort. That people who want to participate are encouraged to. That they sort of throw their hat in there and are encouraged to be part of it. I haven't seen at CFM any intention to exclude or to give some other organization more priority than another.

I feel it's quite inclusive and voices are heard; it seems like equally. I don't see any signs of some voices are more important or some ideas are more important than others that people might have. I think that's one of the assets of CFM.

\begin{abstract}
A few interviewees noted that there may have been instances where there were some "imbalances," but that it did seem out of the norm or excessive:
\end{abstract}

I think that, as with any core team there are probably some people who are listened to more than others. But I'm not extremely aware of a heavy imbalance...

I think you are going to have that, even though groups try really hard not to have that. There's ultimately someone who has to make a decision or float a proposal for further discussion or something and by that drive the decision-making process. You have much more of a representative democracy here...

One interviewee discerned the difference between someone exerting power in the form of valuable leadership (in this case) and someone driving an agenda and excluding others (not this case). Another interview exchange suggested that 1) at times there were dominant personalities but that was not necessarily a problem, 2) process learning about partner characteristics facilitated the ability to work in those circumstances (Hibbert \& Huxham, 2005) and 3) structured activities can help equalize voices: 
There are some very strong personalities and the people involved that have a tendency to kind of take over. Which isn't a bad thing... like $X$ and $Y$ are very, very vocal. If $Y$ 's at a meeting, it tends to go in a certain direction. Which is fine, as things $s$ he's been thinking about ...I've interacted enough with $Y$ to know that's just his/her personality style. If somebody didn't know him/her very well, you could almost get afraid or offended because you might think s/he's being abrasive or confronting... I think the exercise we did at the last retreat where we broke up in little groups. I think that's a good way of handling that because it forces everyone to have a voice on something.

This finding is consistent with other research observing that even when there were substantial power differentials "outside the room," for the most part, surface power was equalized within the MSP setting (Everett \& Jamal, 2004; Poncelet, 2001a). This may be due to norms and expectations surrounding the process (Poncelet, 2001a), recognition of mutual interdependence (Mandell, 1999), or variation in types of power $^{27}$ (Carkhuff, 1999; Huxham, 2003; Lewicki, Litterer, Minton, \& Saunders, 1994).

A few interviewees countered the majority opinion of equality. One interviewee said, "I kind of feel like several of the ideas that I brought to the group have not been considered" (though it is not clear whether this relates to power, social capital, merits of the idea and/or some other factor). Another recalled a time when s/he offered an

\footnotetext{
${ }^{27}$ Power, the ability to do or influence, has many sources including formal authority (recognized right to make a decision), control of critical resources (e.g. expertise, money, network access and influence), discursive legitimacy (e.g., trusted to speak on behalf of a stakeholder), and personal power (e.g., charisma, integrity, patience, emotion) (e.g., Hardy \& Phillips, 1998; Lewicki, Litterer, Minton, \& Saunders, 1994).
} 
idea that didn't move forward and how s/he had figured it was due to personality or priorities or differing perspectives and assumed (incorrectly) that people had conversations $\mathrm{s} / \mathrm{he}$ was excluded from. A third said that $\mathrm{s} / \mathrm{he}$ did not feel there were any power imbalances or marginalization but then noted that s/he felt that maybe some strong personalities dominate in some instances. Interestingly, although many of the Core Team members were not Executive Directors, this member perceived that to be the case and said that sometimes s/he felt "kind of lowly" because s/he did not hold such a position. As Vangen and Huxham (2003b) note, "some are more skilled than others in recognizing their own unique sense of power..." (p. 21).

Of particular note, the three individuals who expressed concerns about power imbalances in the interviews chose not to express their concerns or frustrations during the MCLA process even though they said that they felt safe bringing things up, and expressed fondness for the group. These exceptions are significant for three reasons. First, they demonstrate that even with collaborative competence and an overall open and democratic process some participants may feel a sense of power imbalance and may choose conflict avoidance behaviors rather than surface the issue (a potentially problematic behavior counter to the goals and spirit of MCLA). Second, these reports may indicate that one or more members of the Launch Team (including the manager) were indeed exerting undue influence. Third, they may indicate a need to explicitly (and repeatedly) articulate roles and contributions in order to fortify members' sense 
of value, purpose, and empowerment as well as a need to reflect on process issues in order to provide a check on how the group is operating.

Most of the interview discussions regarding power referred to the workings of the Launch Team/Advisory Board, although a few interviewees made comments referring to the larger process. One interviewee noted that the focus on "key leaders" essentially meant there were power imbalances: "Not that anybody tries to exclude, but it's very exclusive of people who don't have status. This is something that I've seen in other communities too. It's typically how you try to move issues forward. You have people who can actually make decisions." Another noted "in establishing a core group inevitably one is giving them some power." While not intentionally exclusive, the Core Group should have done more to include the larger group - an issue of structuring (considered below) more than power imbalance.

\section{Priority Agendas}

Dominant discourses have been found to prevail in some multi-stakeholder settings, potentially inhibiting shifts toward environmental and social sustainability goals (Everett \& Jamal, 2004; McCullum, Pelletier, Barr, \& Wilkins, 2003; Pelletier, Kraak, McCullum, Uusitalo, \& Rich, 1999b; Poncelet, 2001a). As discussed below, while 
there is evidence in this case to support this assertion there is also evidence that also suggests a more nuanced understanding of discourse dominance.

Sustainability themes are found in both proposed and actual work (explicit and implicit agendas). A review of the draft indicators for a sustainable regional food system (Appendix R) reveals attention given to a range of economic, environmental, and social justice objectives. This is not surprising given that the draft indicators were developed by persons steeped in and committed to sustainability, and were based in part upon a review of other sustainable regional food system assessments. When circulated for review, Board members did not surface any objections to the draft. Although it is possible that their review was cursory due to time constraints and/or because the indicators were still considered a draft, overall support for the indicators and objectives is not unexpected given the strong support for sustainability themes evidenced in Survey One results, the interviews, and other documents. The market, education, and policy initiatives defined in CFM's portfolio of programs included economic, environmental, and social justice objectives and the AmeriCorps and Graduate Assistant projects also addressed a range of sustainability themes (e.g., Oregon Food Bank's Learning Garden, farmland protection research, support to the community food literacy team, research on sustainability indicators). The program that most explicitly addressed underlying systems and sustainability thinking (Community Food Literacy/Seed to Supper) was dropped from the final Kellogg 
Foundation concept paper; however, this was not because the program was not valued but because it was not seen as fitting with Kellogg's funding priorities and because an institutional home for the project had not yet been found.

While a range of sustainability themes was included in CFM agendas, some items received more attention (e.g., market solutions) than others (e.g., farm workers' wellbeing and genetic engineering). There are multiple reasons for these foregroundings and silences. As noted earlier, efforts to recruit the range of food system diversity (including representatives of the farm worker communities) were not fully successful - whether due to poor social networks, geographic barriers, competing commitments, issue framing, and/or unexamined White privilege. Thus, agenda prioritization was very much driven by who showed up. Agendas of stakeholders not at the table were for the most part less likely to move forward not because of overt exclusion but because the expertise and mandates of stakeholders present were oriented to other agendas. Further, a decision to focus priorities does not necessarily imply disagreement. Commented one farm business oriented participant when the work group ranked project ideas in 2001, "all have value." There may have been a sort of "Maslowian" triage to attend to items perceived as most critical (e.g., saving agricultural land from paving before moving on to questions of how the land is farmed, keeping food and farm businesses alive before addressing labor and 
stewardship). Related to this is the point made by one interviewee, "I think that some of this is not so much a matter of priorities but a matter of timing."

At the same time, participant observations indicate that distancing from agendas perceived as potentially controversial (e.g., genetic engineering) may have occurred, perhaps as a strategy to establish the alliance's legitimacy (e.g., not "radical" or "political"). Further, funder priorities and regional context (e.g., hunger was a very visible issue at the time) influenced what agendas prevailed. Indeed, groups that might be expected to have lower status (e.g., food insecure, immigrants) saw their agendas forwarded as team members responded to funding opportunities designed to serve those interests.

Overall, in this case, sustainability oriented agenda items were forwarded particularly when they were consistent with interests of parties "at the table," funder priorities, and the regional context. The degree to which this sustainability discourse embodies an "ecological modernist" perspective is not examined here (Everett \& Jamal, 2004; Poncelet, 1999, 2001a). What is clear is that social and environmental justice goals were included in articulated agendas - whether due to participants' values and viewpoints, regional context (e.g., high visibility of the hunger issue at the time), and/or funder priorities. 
Summary of Power

Power manifests in many ways, facilitating or inhibiting collaboration (Agranoff \& McGuire, 2001; Booher \& Innes, 2002; Hardy \& Phillips, 1998). Strong power imbalances among team members were not evidenced in this case, though some participants held more power in the form of formal authority (e.g., recognized right to make a decision), control of critical resources (e.g., expertise, money, network access), discursive legitimacy (e.g., trusted to speak on behalf of a stakeholder), or personal power (e.g., charisma, integrity, patience, emotion). Some partners were more influential than others, however, in most instances this was more an exercise of leadership than domination: Ample opportunities for partners to exert power were unexercised. As Huxham \& Vangen (2000a) and Vangen \& Huxham (2003a) note, the fact that some participants are more central than others to a collaboration may be because they have chosen to participate at a greater level than others. The authors further suggest that perceptions of power inequality are sometimes exaggerated and unique sources of power underappreciated.

A minority of participants felt that on at least one occasion their voice (agenda) was not adequately heard. The reasons for this are not totally clear. Closer examination of the reported incidents indicate that the agenda items in question were not inconsistent with the group (e.g., market development) and perhaps could be attributed largely to 
poor communication (e.g., running out of discussion time at a meeting and conflict avoidance behaviors) or the fact that in a climate of scarce resources some ideas may be perceived as more timely or appropriate than others. The finding that some participants felt that their agenda items were not forwarded is consistent with other research. For example, McCullum, et al. (2002) found that one third of all participants felt that their viewpoints were downplayed or ignored.

Everett and Jamal (2004) and Poncelet (2001a) suggest that sustainability discourses in MSPs may be limited by an ecological modernist perspective. While this case does not provide conclusive evidence regarding this assertion, it does appear that deep structural power manifesting in the form of meaning management did occur, for example with a focus on market based solutions and distancing by the group from controversial issues such as genetic modification. Whether such tactics were an articulation of held views, an appeal to funder priorities, and/or a legitimization strategy (e.g., trying to seem mainstream or "reasonable"), the result was a discourse that suggests working within the dominant extant (ecological modernization) paradigm. This evidence of deep structural power may reflect a pragmatic theory of change that calls for "meeting people where they are at," "working within the system to change the system," and managing conflicting views so as "to have motion and progress to keep people involved." 
Power, the ability to do or influence, is related to social capital. The following section considers how stores of value embedded in social relations impacted collaboration and domain development in this case.

\section{$\underline{\text { Social Capital }}$}

Social capital, despite definitional and methodological inconsistencies and debates, is an important concept for understanding collaborative alliances. Social capital, defined here as resources linked to a network of relationships, is a store of value facilitating action that helps people get by (support social capital) or get ahead (leveraging social capital) (Granovetter, 1983; Light, 2004; Portes, 1998, drawing on Bourdieu). In this case, social capital is seen to be both an influence and product of collaboration and domain development.

As discussed earlier, social capital in the form of networks, norms, and trust (Putnam, 1993) significantly influenced who participated in the collaborative alliance. Further, this capital influenced how participation ensued, with some individuals and organizations seeming better equipped with the networks, norms, and trust needed to partner successfully. 
Consistent with the literature, many participants reported new and/or improved relationships (e.g., Imperial, 2005; Poncelet, 2001b). Bridging and bonding capital was formed, resulting in individual and collective learning, partnership formation, personal and professional support, and a sense of community or movement. This occurred not only at the Forum, as detailed in Chapter Four, but within the Launch Team/Advisory Board as well. As one interviewee noted:

That's the strength of the system is all the connectivity...a lot of that is what this is about. All these relationships that mean that different good things happen that you'll never know about but they happen because of connections that you made.

Wolff (2001) notes, that "[t]hese benefits accrue as people begin to know, trust, and work with one another" (p. 186). Further, these benefits often come from "things that happened outside of meetings through connections they made participating in the coalition" (Chavis, 2001, p. 316). Examples of these relationship-building dimensions were identified in the interviews. For example:

I think it's heavily a combination of dialogue at meetings and outside of meetings. A lot of times when we're at meetings we have a pretty tight agenda but people chat before and after the meeting with each other. Being part of a group of people and meeting with them regularly, sort of gives you permission to communicate with each other outside of that group in a way that you might not have normally.

There have also been recognitions made innately, at least from my perspective innately, between individuals. So in other words it was one thing to have the ability to come together as the Community Food Matters Launch Team, but it was also interesting that on the way out there could be side dialogue to say that ' $I$ have something that I think specifically relates to kind of what you are doing' and outside of this 
context, in other words this was the context for developing relationship - kind of the external stimulus that came along and brought the group of people together. So that has worked well.

I think that we must be doing something right. Yeah, because it isn't a given that at the end of the day everyone will feel good; having a long discussion in a parking lot as opposed to rushing to some other family or friend or commitment.

We'd meet at a different group member's place and we'd start the meeting with a half hour of that person explaining their role in their job...It seems that is a good thing to start off with as a 'getting to know you' or trust building thing.

In this case, social capital is identified as both an important influence and product of collaboration. Social capital not only shaped participation in the collaboration, but participation shaped social capital - which in turn influenced domain development. Formation of social capital is influenced by availability of other resources, such as time. The following section considers other resources that influenced collaboration and domain development in this case.

\section{Resources}

A number of authors note that human, financial, and time resources are crucial to collaborative success (Chavis, 2001; Hemmati, 2002; Huxham \& Vangen, 2000a, 2004; McCann, 1983; Susskind, Fuller, Ferenz, \& Fairman, 2003; Wolff, 2001). As Huxham and Vangen (2000a) note, "An experienced and competent collaboration 
manager, facilitator or convener is an essential asset, but cannot be expected to deliver for the collaboration without an appropriate level of resource and support" (p. 800). In this case financial resources were unavailable to hire a collaboration manager for the number of hours sufficient neither to the task nor to implement identified projects.

Based on prior experience, the program manager had concerns about convening action groups without adequate resources in place. These concerns were reflected in the October 2001 Draft Concept Paper:

Too often, participants in large group interventions are asked to define action agendas but are not provided sufficient resources for catalyzing implementation of said agendas. The hurdle of identifying resources frequently proves too great and participation wanes. Thus, this design provides for seed funds to facilitate implementation of project ideas developed as part of the collaborative learning and action planning activities.

In actuality, the planning team decided to move forward despite an absence of start-up funds. Their assumption, consistent with that of many LGIs and whole system change designs, was that resources would flow to where there are sufficiently powerful ideas, talent, and energy. This case indicates that assumption is likely an unreasonable one.

A number of tensions emerged around the issue of resources. First, without financial and other resources in place to make projects happen it was difficult for some individuals or organizations to participate (or justify participation). At the same time, 
in a Catch-22, without participation there was little likelihood of securing resources to move forward. Ultimately, members felt stymied by the lack of resources to move forward with identified action agendas. For example, "I think it got to a point in the group- and this is just a sense and with a couple discussions that I had with people; I had the sense that there was a little bit of frustration around not having any money so that we could do something as a group and continue to build." Second, related to the lack of financial resources, was the issue that participants found it difficult to allocate sufficient time to the collaborative endeavor. As one interviewee noted:

I think there are times in meetings that if we had more time, we could have accomplished more. The reality is, we don't have the time. It's just not going to happen. It was really good that we took the time for the retreat this past month and did what we did. I think we accomplished a lot in doing that. But it's that spending time, doing what you need to do.

Such time challenges are common to collaboration (Hemmati, 2002). As Chavis (2001) notes, "in most cases participants are feeling overextended before they joined the coalition, and then they are expected to contribute more to the collaboration..."(p. 315). Third, ambiguity regarding partner roles and responsibilities and concerns about diverting resources from the home organization undermined efforts to secure resources. Fourth, as noted below, too much attention to resource acquisition from one funding source diverted attention from other activities more likely to support collaboration success. 
Overall, while significant investments of time and modest start-up funds were made available, collaboration success was hindered by the absence of sufficient resources which was due in part to direction setting and structuring issues.

\section{Structuring}

Structuring refers to the process of creating a regulative framework to ensure "functional viability" of an interorganizational collaboration (Gray, 1985; McCann, 1983). Structuring defines how the collaborative alliance will operate to achieve identified common interests and goals. The primary issues addressed in the structuring process are designation of roles and responsibilities and relationship management mechanisms (Gray, 1985; McCann, 1983, p. 181). Structure(s) can take one of many forms ranging from informal linkages to formal organizations (Bernard \& Armstrong, 1998; Imperial, 2005; McCann, 1983). Permeable boundaries and changing context make collaboration dynamic, thus, structuring is ongoing and collaborative alliances may move along the continuum over time (Gray, 1985; Potapchuk, 1998; Rosenthal, 1998; Thacher, 2004).

The structuring process in this case formally began when the Launch Team was created in April 2002 and charged with identifying CFM's mission, structure, and 
home. Institutional commitments to participate were secured (one with a formal letter of agreement designating staff representatives, the others providing verbal agreement via the representative). MOUs articulating specific commitments and responsibilities were not created. In July 2002 a governance structure was proposed, though it was never operationalized (Appendix G).

As noted in Chapter Two, in November 2002 the Launch Team accepted Ecotrust's offer to host the launch of CFM. The understanding was that Ecotrust would provide a home for CFM's launch for a few years; the option of a permanent home at Ecotrust would remain open for conversation over time. Specific agreements about roles and responsibilities for "hosting the launch" were not developed. The Launch Team became an Advisory Board after the decision was made to move CFM to Ecotrust. It was suggested that being on the Board would entail meeting four times per year, reviewing and providing input on work plan and strategy, providing ideas and resources for events, providing content to the listserv, assisting with fundraising, and having the home organization name listed on CFM letterhead. In reality, roles and responsibilities were not clarified or formalized, including communication frameworks and decision-making protocols. Time to discuss Board roles and responsibilities was placed on the agenda for the May 2003 Board meeting, though the discussion was eliminated due to time constraints when the group decided to have a half-day retreat rather than a full day retreat. 
In April 2004, funding-related programmatic changes prompted Ecotrust to abandon its agreement to launch CFM. At the May 2004 Board retreat a model of selforganization was offered by a professor and consultant in non-profit management who facilitated the meeting. The proposed self-organizing coalition model included a rotating chair or convener, memoranda of understanding among partners (including a statement of principles for guiding decisions), and an "executive committee" charged with such things as approving letters of support, position statements, etc. The model was not instituted, as significant questions remained unanswered. These included: ${ }^{28}$ :

- Is a strategy or agenda defined for the organization: Do we chart a course for achieving the three priorities or do we simply wait for coalition members to initiate activities that hopefully move toward the goal? If activities are spontaneously proposed and implemented by partners is there any mechanism for ensuring continuity and compatibility between activities and/or movement toward the mission and objectives? Do people sign up for sub-committees (e.g., clearinghouse team, networking team)?

- Does the Executive Committee "approve" suggested CFM activities? For example, if someone is working with PSU faculty and students to implement a Forum or collect some clearinghouse information does this get approved first by the Executive Committee?

- How long is the rotating convener's term and what are their responsibilities? Do they convene Executive Committee meetings and, if so, how often? Are they responsible for convening a minimum number of events for the full CFM community (e.g., an annual member Forum)?

- How is the Executive Committee selected and how long do they serve? What are their exact roles and responsibilities?

- If there is no staff, who answers emails, requests for information, requests for speaking, coordinates information and activities, etc.? Do

\footnotetext{
${ }^{28}$ From May 5, 2004 Board Minutes
} 
we wait for a coalition member to "spontaneously" decide to create a CFM website?

- When is something a CFM co-hosted event? For example, if OFB puts out a call that they are going to host a food security speaker and asks if anyone wants to collaborate and some coalition members join in what makes it a "co-hosted by CFM" event?

- If CFM does not have non-profit status what are the implications? Who manages the money (e.g., fees from a Forum, grants to support staff and/or event)?

- What is the mechanism for engaging (and expanding) the larger CFM membership? Do they all sign an MOU or are MOUs only Executive Committee Members? What makes someone a coalition member or partner?

- Do coalition members pay a sliding scale fee and, if so, how much? What is the current director's role?

Next steps were defined, but not implemented. These included:

- Draft MOU and operating principles and practices (with assistance from facilitator and possible a PSU student or AmeriCorps volunteer).

- CFM Advisory Board will meet to review and discuss the draft operating principles and structures and make decisions. Members wishing to step down from Board may do so.

- Circulate update of meeting and decisions to general "membership" (the listserve).

- Suggest Executive Committee meet monthly for $11 / 2$ hours vs. longer, less frequent meetings.

It is not known whether the inability to address these questions and move forward with a self-organizing (or other) model reflects a lack of support for the self-organization idea, scarcity of resources to work on the initiative, diminished support for CFM, lack of leadership on the part of the Advisory Board, and/or other factors. 
In 2005 CFM "moved" to PSU's School of Community Health and Nohad A. Toulan School of Urban Studies and Planning, though it was clear that the institution's commitment was more one of providing a "parking space" for the alliance than leadership to ensure its longevity. When Advisory Board membership was revisited in $2005 / 2006$, it was suggested that members would meet two to three times per year and provide key insights and direction regarding strategy. This description represents a dramatic shift from the original conception of CFM as a partnership of organizations guided by a Board with full accountability for the alliance.

The importance of defining appropriate structures cannot be overestimated. As McCann (1983) notes, even when the desired direction of a social problem solving initiative is correct, "the inability of stakeholders to negotiate needed roles and responsibilities and perform regulative functions will ultimately limit the viability of their problem domain." (p. 181). Poor definition of roles, responsibilities, and rewards is a common obstacle to collaboration success. This, coupled, with resource scarcity, competing demands, poor direction setting, and lack of institutional support, resulted in unsuccessful structuring in this case. 


\section{Collaborative Alliance Summary}

There are many perspectives informing collaboration theory - no one of which is sufficient to explain the phenomenon. This case demonstrates how a range of factors interacted to influence collaboration success and, subsequently, domain development. These include stakeholder participation, vision and direction setting, leadership, power, social capital, resources, and structuring, and include a number of "subfactors" such as trust or communication.

In this case, efforts to engage key system stakeholders were impacted by social networks, framing, resources, and legitimacy. Although some difficulty engaging the full range of stakeholders was encountered, a collaborative alliance management team with members representing diverse stakeholder interests was formed and the diversity of participants was sufficient to stimulate learning, networks, and partnerships. Stakeholders from the extended field were not as successfully engaged. This included the larger community as well as Forum attendees. As reflected in one interviewee's comments, there was a sense that "we definitely have not included the larger group [Forum attendees] very effectively or very well or made them feel like members... I think we failed, frankly... It's just not knowing quite what to do with that at this point." The issue of how to ensure that others are not left out (or feel left out) is not uncommon in collaboration (Huxham \& Vangen, 2000a). However, as McCann 
(1983) notes, "[t]he referent organization cannot make too much of the going itself. The domain community must become part of the learning-appreciation process and must at critical junctures be convened" (p. 182). Weak engagement with the extended field diminished opportunities for networking, system appreciation, and communication of alliance achievements and value.

Collaboration success is also tied to presence of a shared vision for the organization and the domain. In this case, there was general agreement regarding the vision for the domain, tinged with a degree of ambiguity that likely served as an asset by providing · latitude for diverse stakeholders to work together. Ambiguity regarding organizational focus and roles and responsibilities undermined structuring efforts and negatively impacted the viability of the collaborative alliance - a not uncommon phenomenon in collaboration (Eden \& Huxham, 2001). Although Community Food Matters' core functions of convening stakeholders, collecting and sharing food system information, and catalyzing projects to address identified gaps were identified early in the life of the alliance, the conceptualization of "catalyzing" was muddled. Further, the focus on implementing a portfolio of food system projects ${ }^{29}$ was likely a mistake in this case. First, the project focus (poor direction setting) may have had a negative impact on structuring both by prompting concerns about turf and by creating the perception of a

\footnotetext{
${ }^{29}$ While forums or research can be seen as projects, here the term refers to direct service activities such as the food entrepreneur program or food system curriculum effort.
} 
new organization - thus contributing to Advisory Team members and their respective organizations behaving more as advisors to an organization rather than members of an alliance. Second, the assumption that parties with common interests and goals would easily work together was naïve: In some (but definitely not all) instances, parties at the table were unable or unwilling to collaborate on projects - either due to a lack of resources, competing demands, personalities, and/or questions regarding how projects would augment rather than supercede or absorb members' own initiatives. Third, misplaced efforts to develop and fund projects diverted scarce resources from more important core functions. As one interviewee said, "Because we saw fundraising to do a project as our focus, we obviously had a failure." A great deal of time and energy was expended looking for much needed resources, however the emphasis of this effort was inappropriately directed.

A number of positive leadership attributes identified as important for collaboration success were present. Overall, the group demonstrated a systems view and collaborative perspective, and the process was identified as participatory, fair, and democratic. At the same time, weaknesses were identified as well. Leadership efforts were sometimes hindered by insufficient authority, time and money resources, and/or organizational support - another common collaboration dilemma. Also, the common tension between ideals of participatory, democratic leadership and the frequent reality of a champion or leader who assumes responsibility and "gets things done" was 
exhibited (Huxham, 1996; Vangen \& Huxham, 2003a, 2003b). Further, processes to facilitate communication and open participation did not ensure productive conflict resolution (i.e., conflict avoidance behaviors were observed) or engagement (e.g., competing demands sometimes constrained participation).

Power differentials and dynamics can be substantial in some collaborations, but were not observed to be so in this case. Overall, power appeared to be well distributed and few power struggles or imbalances were identified. ${ }^{30}$ Where perceptions of power imbalance were noted, miscommunication and conflict avoidance were seen as contributory. The process design, participant profile (i.e., strong sustainability orientation), and lack of extant conflict likely contributed to the relative absence of surface power issues. The degree to which deep structural power (in the form of meaning management) may have influenced agenda setting is not clear though, again, the participant profile and process design (coupled with emerging contextual issues such as global climate change) likely mediated the influence of dominant or conventional societal discourse.

Social capital was observed to be both an important input to and product of the process. Bridging and bonding capital facilitated the exchange of ideas and resources,

\footnotetext{
${ }^{30}$ Although surface power did not appear to be an issue for most participants it could be considered an issue with respect to non-participation: As one interviewee noted, while the process was participatory and fair for those engaged, he was more concerned about who did not show up and why.
} 
with many effects occurring as a spin-off from relations developed through participation in the MCLA process. Not surprisingly, human and fiscal resources were confirmed as important to collaboration success. Their relative scarcity or abundance was found to be related to such issues as framing, engagement, social capital, and outcome advocacy.

(Huxham, 2003, 1996) notes that collaborative inertia appears to be more common than collaborative advantage - despite the logic of collaboration. In this case, although many attributes for success were in place, the collaborative alliance faltered. A viable institutional host was not identified, and members able or willing to operate under a self-organizing model. When the convener/manager stepped away because of a lack of resources, the collaborative alliance effectively ended.

\section{Synthesis}

Analysis of the large group intervention (Forum) and collaborative alliance has contributed to understanding about design for each of these components. In this section, findings regarding the large group intervention and collaborative alliance are synthesized and the two components are considered in relation to each other and to inter-organizational domain development theory. Such a synthesis provides a more 
rich and complete picture of the case and further enhances understanding about how and why MCLA processes work.

Not atypically, this multi-stakeholder processes was initiated by a boundary spanning social entrepreneur/change agent (Folke, Hahn, Olsson, \& Norberg, 2005; Gray, 1985; Hemmati, 2002; Huxham \& Vangen, 2000a; McCann, 1983; Westley \& Vredenburg, 1997). The problem setting and direction setting phases began with the convening of a group of food system stakeholders to consider possibilities for more collaborative, systemic approaches to regional food system issues. Finding agreement regarding a need and opportunity, the group set their direction to include creation of a referent or bridging organization (Community Food Matters) and a portfolio of programs supportive of regional food system sustainability.

A large group intervention (Forum) was held with the aim of increasing understanding of regional food system issues, defining action strategies in support of sustainable regional food systems, building networks among individuals and groups working on various facets of the food system, and launching the referent organization. As per Trist (1983) and Gray (1985), the Forum event was facilitative of domain development. Domain development was also facilitated by Community Food Matters functioning as a referent or bridging organization. As noted in the interviews: 
It's created a place and a context for people to talk about and work on those issues...which is no small thing.

It's allowed me to hear from different people, participate in different discussions that bring all of these together and there's really no other forum that I know of that's really done this. There's no other forum within the Dept of Ag that does this... There's no place that I know of inside the University system that brings all these people together. Well, this does that. That to me is the biggest thing. It is taking a systems approach to this issue.

I think people have found that they have more common ground than maybe they understood they had in the past. It also provides a platform to actually brainstorm activities. To attempt concrete activities that can be done.

I think they're bringing a lot of people in under the tent. They're including a lot of people that might not have seen themselves as being connected with this comprehensive effort creating a healthy regional food system.

The MCLA process employed whole systems, constructivist, and participatory principles, as well as adult and social change learning perspectives. Results were generally consistent with the literature (e.g., primary and secondary, tangible and intangible effects such as substantive and relational learning and development of networks, partnerships, system appreciation, and collective identity). Inspirational effects neglected in the literature were also observed. Challenges related to stakeholder recruitment, implementation of action agendas, and doxic ${ }^{31}$ sense of time were confirmed.

\footnotetext{
${ }^{31}$ Everett and Jamal (2004), drawing upon Bourdieu, use the term to refer to conventional or dominant beliefs and practices.
} 
Consistent with the whole systems principle, diverse system stakeholders participated in the process. Stakeholder recruitment and retention were influenced by framing, competing interests, resources, legitimacy, institutional support, and social capital; these factors were found to be fluid over time (e.g., legitimacy of the issue and the alliance appeared to increase). Participation by the full range of stakeholders did not occur, however, there was sufficient diversity to bring a whole systems view to the issue and to achieve a range of impacts suggested by MCLA theory (e.g., increased understanding, networks, system appreciation). As one interviewee noted:

I'm a big fan of it and a big fan of your work. I'll tell you why. Number one it's a great opportunity for me to learn a whole lot more than you know about the subject and to meet people that I wouldn't have exposed myself to because they are a little bit outside my circle... And that's very helpful to me.

Even when individuals had an existing relationship, the context of the MCLA process sometimes prompted them to relate differently. As one interviewee noted, "I remember, I talked to L like, every other week, but even at that conference she told me something I didn't know because it just came up in a different setting." Another interviewee noted that it was only in the context of the large group intervention that she and a friend began to relate to each other as colleagues and contemplate how they could work together (leading to a very successful partnership). 
It is important to note that MCLA processes work not just by convening stakeholders but also by convening them in a particular way. In this case the positive, participatory, dialogic, diversely engaging, and systemically oriented design features of the MCLA process contributed to intangible effects such as learning, trust building, norm development, and inspiration that facilitated intangible and tangible effects such as knowledge creation and transfer, partnerships, and program changes.

The MCLA process had a tone and form that served to "broaden and build" in the sense discussed in psychology literature (Fredrickson, 2001, 2004). That is, where negative emotions can narrow thinking and development of relationships, positive emotions may serve to broaden thought-action repertoires and build enduring personal resources (Fredrickson, 2004, p. 166). In this case, cultivating a space of inquiry and connection rather than positionality and hostility likely elicited emotions supportive of relationship building and integrative, creative, flexible thinking. Form and tone facilitated process learning as well. For example, one interviewee noted, "I feel that it is modeling for me how to hear a different point of view on things that I feel passionately about without becoming defensive or putting up a wall...just kind of listening and thinking. You know, 'I have something to learn from this person."' For some, the positive setting elicited a sense of hope. For example: 
Gives me hope and energy.

It's been spiritually energizing to associate with a group of people with so many varied interests and goals. And appreciate that we really are part of one large system.

Felt like part of a movement.

Reinforced my desire to be part of social change.

This finding is consistent with Ludema et al.'s (1997) suggestion that hope is born in relationship and inspired by the conviction that the future is open and can be influenced, is sustained in dialogue, and can be a valuable resource for creating positive knowledge and action in communities (p. 1017). The broaden and build theory is also consistent with organizational and community development literature positing productive effects of a focus on the positive (e.g., appreciative inquiry, asset based development, common ground) (Finegold, Holland, \& Lingham, 2002;

Kretzmann \& McKnight, 1993; Ludema, Cooperrider, \& Barrett, 2001; Weisbord, 1992).

Consistent with dialogic and constructivist theories, the MCLA process provided a space for the learning that can occur in story and conversation. As Sandercock (2003) notes, "stories teach" (p. 25). In panel presentations, field trips, and one-on-one meetings, stories and conversation provide examples and a way to concretize the abstract (Bunker \& Alban, 1997; Ganz, 2001; Sandercock, 2003), thus facilitating development of understanding, empathy, and personal power. For example, one 
survey respondent noted, "inspirational stories will impact my perspective on my own personal power." Said another, "hearing Doc speak from his evolving position helped me to see myself, my limitations, as changing too." Recall also the interviewee who developed a new schema after considering alternative viewpoints, the interviewee whose compassion increased after learning more about what it takes to be a farmer or food processor, and the interviewee who changed behaviors after listening to others and realizing s/he could act similarly. Of particular note is the fact that these changes in viewpoint proved to be integrative and expansive rather than narrowing. These findings are consistent with research that suggests relationship closeness can facilitate perspective taking that leads to greater empathy and support as well as reductions in stereotyping (Galinsky \& Moskowitz, 2000), and that sharing of personal experiences can lead to increased comfort, connectivity, and understanding of self and other (Nagda, 2006).

Cultivation of system appreciation was built into the MCLA design via both content (e.g., highlighting system connections) and process (e.g., engaging diverse system stakeholders). Regarding system appreciation, one interviewee noted:

[T] hinking what does this- how does this change my frame of reference? ... bringing in diverse people and getting diverse sets of opinion and different viewpoints is very wholesome to this whole thing. It's made me think about that probably more- it's almost subconsciously... I'm doing this at times and I'm thinking that it's probably because we've been exposed to this [CFM process]. Because it didn't come from anywhere else. 
For some participants, system appreciation helped contextualize their work. For example, respondents noted:

Better understood my role in the larger picture of sustainable food work regionally.

Helped me see my place in our regional community.

I am now more aware of how all the different people and organizations represented here really depend on each other to make us all successful in our own work.

Similarly, some participants gained a sense of cohesion and connection as system appreciation provided a window into wholeness (Flood, 2001) and fostered a sense of group (Poncelet, 2001b, p. 288). For example, "For one thing, I feel supported... I like feeling placed in a larger system. That just changes the nature of the work! To understand that you're part of something larger." Placing oneself in the system can be important for overcoming a sense of isolation and reducing alienation and despair (e.g., Brookfield, 1994; Dokecki, Newbrough, \& O'Gorman, 2001; Dukes, 1996; Lange, 2004). Further, seeing that one has something to contribute can be empowering (Poncelet, 2001b, p. 292).

Relationship transformation was facilitated by providing a space for participants to learn about each other and build trust. Trust, which is suggested to have cognitive and 
affective dimensions, ${ }^{32}$ exists where there is an expectation of certain behaviors and a willingness to take the risk that the partner will meet those expectations (Ferguson \& Stoutland, 1999; Huxham \& Vangen, 2000a; McAllister, 1995; Vangen \& Huxham, 2003b). Trust may be enhanced in a "virtuous cycle," increasing when a party learns that their expectations are met (Gulati, 1995; Vangen \& Huxham, 2003b). In this case, relational learning, identification of common ground, and the development of trust and norms facilitated collaboration where it otherwise might have been hindered. As these interviewees noted:

For example, $\mathrm{X}$ has been pretty bold in saying that she thinks I'm a little bit out there. But at the same time she hasn't walked away. She's continued to work with me and be involved in policy matters. I think that people have a stake in getting along, basically. They're not as likely to walk out, sort of give up on someone, because they've been in this collaborative relationship before.

I think that this collective learning process is a way of consciously developing a set of values, beliefs and norms around this particular issue of food systems that has power, and authenticity, and is seductive. You want to join. You want to be a part of it. When an activity comes from something that's driven by a collective understanding of what the value is, there's a huge amount of momentum to actualize that.

${ }^{32}$ Cognitive based trust is related more to evidence (e.g., dependability) and affective based trust is related more towards emotional bonds (McAllister, 1995). Other suggested dimensions of trust include motives, competency, dependability, and collegiality and fairness (Ferguson \& Stoutland, 1999, p. 44). 
Learning and relationship building in MCLA processes occurred in non-formal educational settings (e.g., a large group intervention or workshop) as well as incidentally (e.g., coffee breaks or carpooling to an event). ${ }^{33}$ For example:

I did not know all of the emergency food side of the story until I met $\mathrm{X}$. When I started talking about statistics in the food system [for a presentation s/he was giving], she said, 'You're missing part of the story. I'm gonna send you some information.' Now that didn't happen at a meeting; it happened in one of those side conversations. A break or whatever. She said, 'You need to have this.'

Bonding and bridging social capital suggested as important for learning, collaboration, and system change was fostered in the process (Falk \& Kilpatrick, 2000; Hardy, Phillips, \& Lawrence, 2003; Kilpatrick, Bell, \& Falk, 1999; Lasker \& Weiss, 2003; Marsick, Bitterman, \& van der Veen, 2000; Perkins et al., 2007; N. Phillips, Lawrence, \& Hardy, 2000; Tenkasi \& Chesmore, 2003). For example, the interviewee quoted above went on to tell how other alliance members also contributed information and additional contacts for the presentation s/he was giving and how versions of the presentation were made to a wide variety of audiences, often at the request of these members. Thus, learning by individual participants moved to other system members, fostering learning at organizational and domain levels. As one interviewee noted, "the learning about other peoples' issues is really happening ... it just filters down. You

\footnotetext{
${ }^{33}$ Though the terms are not used consistently in the literature, in general, learning has been categorized as formal (intentional, highly structured, institutionally sponsored), informal or non-formal (intentional but not highly structured), and incidental (unintentional and often non-consciously) (Marsick \& Watkins, 2001; Rossing, 1991). Characterized as settings, examples include, respectively, a school, a workshop, and an everyday life setting such as a meeting.
} 
tell other people about it too." Said another, "it is beginning now to make linkages to a variety of other already existing entities, like the Development Commission or the Ag Extension Program."

Of course, while social units can learn, and do so through their members, social units do not necessarily learn when their members do. The transfer of learning from individual to group is influenced by many factors including organizational culture, structures for information sharing, and how the individual conceptualizes relationships between individual and group (e.g., Diduck, Bankes, Douglas, \& Derek, 2005; Everett \& Jamal, 2004; Falk \& Kilpatrick, 2000; Jansen, 1996; Marsick, Bitterman, \& van der Veen, 2000; Parson \& Clark, 1995; Perkins et al., 2007; N. Phillips, Lawrence, \& Hardy, 2000). While individuals were the embedded unit of analysis in this research, as demonstrated in Chapter Four, interviews and archival evidence indicate that field effects were evidenced. An example of the link between individual and organizational and domain learning can be found in one interviewee's observations about a shift at the Oregon Economic and Community Development Department regarding food systems. This person noted, "it has been a valuable education to people in the department; when I see something that is relevant I send it to them. It helps raise consciousness." 
Synthesizing findings regarding the large group intervention and collaborative alliance, this research enhances understanding regarding how and why MCLA process work. Figure 2 provides a graphic representation of these findings.

\section{Figure 2: How and Why MCLA Processes Work}

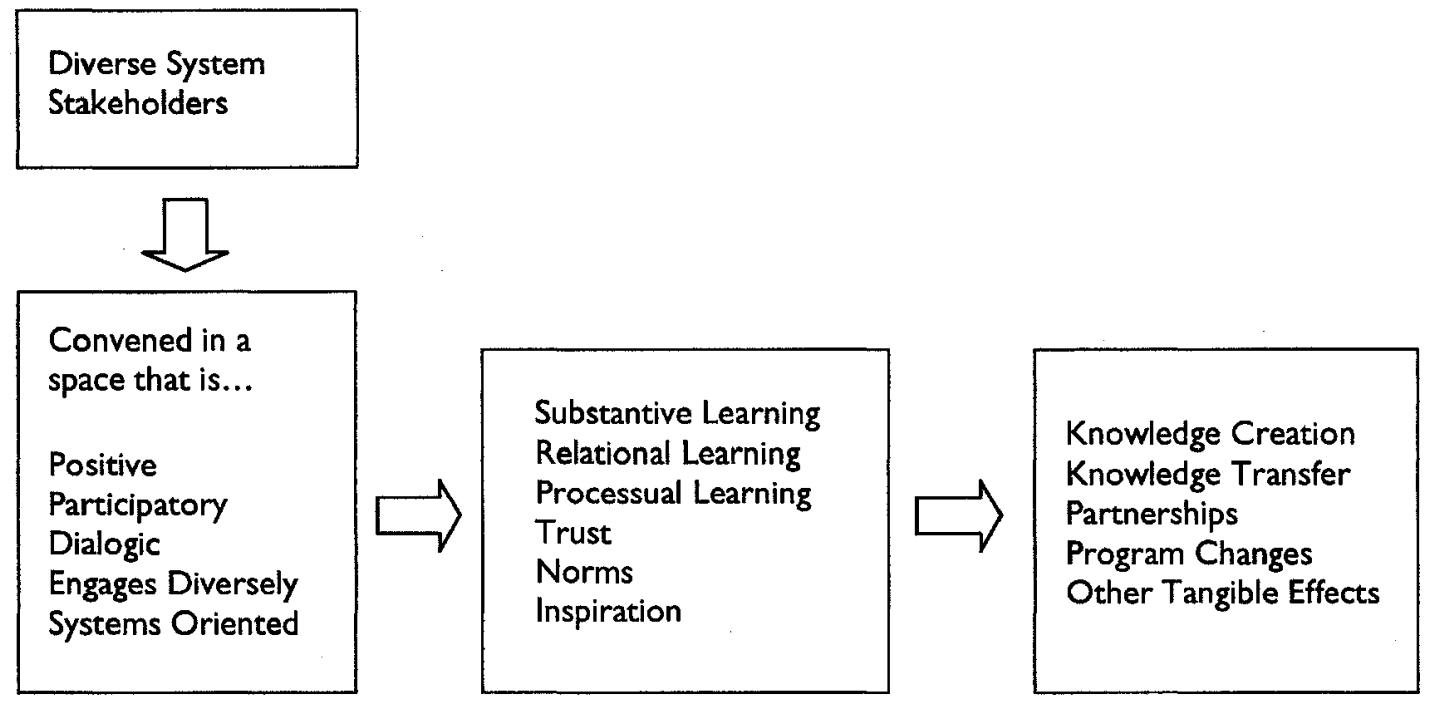

While whole system, participatory, constructivist, and adult and social change learning principles were applied to good effect in this case, a number of issues were identified as well. First, although surface power did not appear to be an issue for most participants, more subtle and pervasive deep (structural) power dynamics may have influenced meaning making - including who participates and how, as well as agenda setting. Second, despite facilitative communication processes, an open and respectful climate, and the presence of collaborative competencies, incidents of 
miscommunication, conflict avoidance, and non-engagement were observed. Metacommunication or communication about process may have improved collaboration success - particularly regarding clarification of roles and responsibilities and more critical reflection about the project focus (e.g., Enayati, 2002; Mattessich \& Monsey, 1992). Third, the participatory and constructivist principles suggesting that people "own" what they help create and the system principle suggesting self-organization proved problematic. Notes Oels (2002), "even a procedurally optimized event can only be as good as the context it is embedded in" (p. 354).

Ultimately, despite positive impact on individuals and the domain, successful structuring did not occur. Consistent with Gray (Gray, 1985), weaknesses or shortcomings in one phase were seen to negatively impact other phases. Further, as Imperial (2005) notes, it is common to underestimate the challenges associated with forming a collaborative organization (p. 302). Despite the strong rationale for collaboration, there are many barriers to its success (e.g., Bardach, 2001; Gray, 1985; Hemmati, 2002; Huxham, 2003; Huxham \& Vangen, 2004; Imperial, 2005; Lasker \& Weiss, 2003; Margerum, 2002). For example, collaboration requires significant time and resource commitments - a challenge magnified when opportunity costs are high and margins are low. Further, it can be difficult to mesh norms, timeframes, and priorities of diverse organizations. There may be resistance due to negative past experiences with collaboration or concerns about loss of control, flexibility or ability 
to take credit. Participants may struggle to balance fidelity to their home organization with personal and/or collaborative goals. The "ramp up" time associated with establishing a new organization (e.g., discovering what activities to undertake, determining how to manage the alliance, acquiring resources) may not occur quickly enough for the organization to succeed.

Thus, while this MCLA process contributed to individual and system knowledge and facilitated individual and collaborative activity supportive of movement toward a shared vision or goal, the inability of the collaborative alliance to effectively structure leaves the domain absent a referent or bridging organization. Currently, there is not an organization holding the system view and convening diverse stakeholders to foster domain appreciation (e.g., interconnectedness, emerging trends, and shared future vision), facilitate networking, and provide domain regulation and infrastructure support. Without such a referent or bridging organization the domain remains under organized and may be less able to govern adaptively. 


\section{CHAPTER SIX}

\section{CONCLUSIONS, IMPLICATIONS, QUESTIONS}

Multi-stakeholder processes (MSPs) are suggested in situations that are plural, complex, and uncertain. In particular, multi-stakeholder collaborative learning and action (MCLA) process are suggested for increasing individual and system knowledge and facilitating individual and collaborative activity that supports movement toward a shared vision or goal. Addressing questions regarding what reasonably can be expected from these processes and how best to design them, this research applies diverse theoretical lenses to the analysis of two components of a MCLA case - a large-group intervention (Forum) and collaborative alliance. In this chapter, key findings are summarized and implications for theory and practice drawn.

This research unequivocally supports the proposition that multi-stakeholder collaborative learning and action processes can increase individual and system knowledge and facilitate individual and collaborative activity that supports movement toward a shared vision or goal. Tangible and intangible, direct and indirect effects are likely to be observed at individual and domain levels. It is not expected that all participants will be similarly or equally affected, or that all MCLA processes will evidence the same types and amounts of effect. However, it is expected that well 
designed and implemented MCLA processes will evidence, in varying degrees, the following: increased system appreciation and understanding about domain issues and partners, new and enhanced relationships, knowledge transfer and creation, belief and value clarification, behavior change, programmatic change, improved collaborative capacity, and increased sense of group, community or movement.

With respect to process design, this research confirms the effectiveness of whole systems, participatory and constructivist design principles, as well as the importance of attending to diverse learning and personality styles. It also supports research that questions the reasonableness of unqualified expectations for self-organization regarding both action agendas and collaborative alliances. Further, consistent with prior research, this case identifies tensions between ideal and doxic communicative practices.

With respect to domain development, this research confirms that large group interventions can facilitate problem setting, direction setting, and/or structuring. Further, they can effectively foster the system appreciation, networks, and shared vision identified as important to domain development. The importance of referent or bridging organizations is validated, though difficulty structuring such alliances is also confirmed. 
This research supports the contention that intangible and second order effects may be equally or more significant than first order and tangible effects. Such effects include improvements in social capital, collaborative capacity, and understandings of self, others, and system (e.g., Connick \& Innes, 2003; Innes \& Booher, 1999a; Poncelet, 2001b). Appreciation for the influence of contextual features such as participant characteristics, process design, institutional support, and environmental factors is also developed.

This research demonstrates that a number of factors, together, help to explain how and why MCLA processes work. MCLA processes create time, space, and a positive setting for learning to occur and relationships to develop. In this space, stories and conversations are shared that may foster bonds and solidarity, provide normative guidance, show a new way, or fuel a sense of the possible (Connick \& Innes, 2003; Finegold, Holland, \& Lingham, 2002; Forester, 1999; Ganz, 2001; Imel \& Zengler, 2002). The positive tone and learning orientation, reinforced with ground rules and norms, may facilitate creation or transformation of relationships as well as generative and expansive thinking (Fredrickson, 2001, 2004; Ludema, Wilmot, \& Srivastva, 1997; Poncelet, 2001a). Common ground and shared vision may be identified, particularly to the degree that the process designs for this discovery. The MCLA setting fosters development of networks, norms, and trust. The bridging and bonding capital created can lead to a number of positive benefits; for example, knowledge 
exchange and creation, a sense of belonging or support, and development of new or altered programs. Appreciation of system interrelatedness is cultivated - an appreciation that can help participants contextualize their work and, for some, foster a sense of cohesion, integration, or connection. Further, for some participants, the system appreciation, common ground, and/or relationship building elicits feelings of inspiration, hope, or a sense of movement or community.

Understanding how and why MCLA processes work provides insight into their applicability to community development and social movement theory. To the extent that MCLA processes foster solidarity ${ }^{1}$ and agency (Bhattacharyya, 2004), collective identity (Chile \& Simpson, 2004; Polletta \& Jasper, 2001; Waddock, 1999), social networking (Gilchrist, 2000), community learning (Moore \& Brooks, 2000), congruence of frames (Snow, Rochford Jr., Worden, \& Benford, 1986), and community capacity (Chavis, 2001), they can be seen as a potent tool for community and movement development. Where MCLA processes cultivate a sense of coherence and belonging, inspire, empower, or foster bridging and bonding capital, they may facilitate community and movement development.

Understanding how and why multi-stakeholder collaborative learning and action processes work also yields insight regarding their applicability to adaptive governance

\footnotetext{
${ }^{1}$ Defined as shared identity and norms (Bhattacharyya, 2004).
} 
theory. Features associated with successful MCLA have been identified as important to adaptive governance of bio-social systems facing conditions of complexity, uncertainty, and plurality. These features include cultivation of system appreciation, generation and sharing of information pertinent to system regulation, development of bridging and bonding capital facilitative of enhanced system performance, and identification of shared vision and common ground (Folke, Hahn, Olsson, \& Norberg, 2005; Hahn, Olsson, Folke, \& Johnsson, 2006; Innes \& Booher, 2002; Lebel et al., 2006; Olsson et al., 2006; Paquet, 2004). Thus, to the extent that MCLA processes create conditions for development of system appreciation, learning, and organization, they can enhance capacity for adaptive governance.

Understanding of likely effects and key design considerations regarding multistakeholder collaboration and action has been advanced by this research, however, a number of questions and issues remain. These questions, addressed below with implications, pertain to stakeholder participation, dominant discourses, engagement practices, the role of referent organizations, measurement of effects, comparability and appropriate use of various processes, and support of sustainability and social change. 


\section{Stakeholder Participation}

By definition, multi-stakeholder processes require participation by diverse stakeholders, yet said participation can be difficult to achieve. The literature is replete with tales of challenge engaging certain populations (e.g., Everett \& Jamal, 2004; Polanyi, 2001; Schafft \& Greenwood, 2003; Susskind, Fuller, Ferenz, \& Fairman, 2003) - a circumstance encountered in this case. This challenge is explained in part by the fact that stakeholder diversity includes difference in motives and capacity for, and timing and type of, participation (e.g., Margerum, 1999; Powell, Koput, White, \& Owen-Smith, 2005; Stringer et al., 2006; J. F. Warner, 2006). A range of structural or individual constraints to participation may be present. For example, stakeholders may not be concerned with the issue simultaneously, may feel unconvinced about the process' benefits or the convener's legitimacy, may experience competing demands, find the discourse alienating, feel outnumbered, have concerns about co-optation or turf, or lack institutional support (Diduck, Sinclair, \& Shymko, 2000; Everett \& Jamal, 2004; Gray, 1985; Schafft \& Greenwood, 2003; Stringer et al., 2006; J. F. Warner, 2006). Sincere and strenuous efforts to be inclusive are important, but not to the point of inertia or paralysis (Grubbs, 2002). It may be that more visionary stakeholders or early adopters begin the process and the process then stimulates a shift in salience and participation (Trist, 1983; Weisbord, 1992). 
When recruiting participants, essentialist lenses must be avoided, respecting that people create their own identity and often manage multiple identities (Drennon, 2002; Everett \& Jamal, 2004; Marsick \& Watkins, 2001). It is also important to be clear whether participants are representing a particular group or organization or are considered representative of a group (i.e., empowered to speak and act on behalf of the group or present as part of a sample reflecting a range of interests and opinions) (Huxham \& Vangen, 2000a; Margerum, 1999, p. 185). When an individual is serving as a representative, it is imperative that $\mathrm{s} / \mathrm{he}$ acts as a conduit between the process and the group being represented. Further, when representing an organization, communication and coordination with the host organization needs to be addressed and organizational roles, responsibilities, and rewards specified.

Participation will likely be dynamic over time (Gray, 1985; Hibbert \& Huxham, 2005; Huxham \& Vangen, 2000a). As the process moves forward, individual and/or organizational interest in participation may shift due to such factors as changing domain conditions, perceptions of convener legitimacy, visibility and salience of the issue, framing, and/or attractiveness of other participants. As new participants enter the process attention must be given to relationship building as well as to the tension of welcoming new ideas without abandoning agendas and commitments (Calton \& Payne, 2003; Gray, 1985; Hardy \& Phillips, 1998; Huxham \& Vangen, 2000b; Vangen \& Huxham, 2003). 
The dimensions of most MSPs, and particularly those addressing sustainability and social change, are sufficiently large as to suggest a variety of types and amounts of participation. Significant questions remain regarding the meaning and mechanics of participation by diverse system stakeholders. What does it mean to participate? How much participation is enough? Who should be involved and how? Innes and Booher (2004) and Stringer et al. (2006) suggest that a range of participatory strategies may be appropriate including, for example, linking efforts of varying scale and duration (e.g., a small subset of individuals participate in a long term series of meetings while others participate in more limited or discrete settings such as forums, web-based dialogues, workshops, or focus groups).

In this case, despite efforts to recruit low income and minority populations, the participation rate by these groups in the MCLA process was low. Yet over time, some members of these populations participated in and benefited from programs that originated with the process: for example, an immigrant farmer program, a Native fisheries economic development project, and various low-income food access projects. Processes that focus on key decision makers may reduce the potential for improved system understanding and may perpetuate inequalities and patriarchal practices that emphasize betterment rather than empowerment (Himmelman, 2001). At the same time, there are rational reasons for individuals to participate in varying ways and at 
varying stages of a process. Populations willingly absent from one setting may participate actively in a related program or setting. Given the goals and guiding

principles of MCLA, questions regarding the meaning and mechanics of participation demand careful consideration.

\section{Dominant Discourses}

A clear picture of how power manifests in MCLA processes has not emerged and the topic merits further study. Of particular interest here is the issue of dominant discourses. Environmental or social justice issues surfaced are often framed within dominant conceptualizations of markets, science, and rationality. Diagnosed as the manifestation of deep, structural power (e.g., meaning management), this framing is seen as inhibiting opportunities to more effectively examine issues and innovate alternatives ((Everett \& Jamal, 2004; Poncelet, 2001a).

What is not clear is whether, in at least some circumstances, the use of dominant discourses reflects not cooptation but a strategy to frame things in a way that will resonate for other participants. Given that successful interface with another party is significantly affected by the ability to "frame" an issue in a way that resonates with their schema (Gray, 2004), use of dominant discourse may be a very pragmatic 
strategy for engagement. As one participant in this case noted, "Every time I speak to someone about this issue/concept I realize ... 'food systems' is still an unknown concept to many people." The same holds true for many conversations about sustainability. Engagement is a real challenge in the absence of common frames and language. Thus, without diminishing concerns regarding the reproduction of dysfunctional, hegemonic discourses, it is important to distinguish whether the use of particular discourses reflects rational behavior in accordance with a theory of change that suggests "getting to the table" by framing in way that connects. Further, if indeed this strategy is being used, questions remain regarding its legitimacy and effectiveness. For example, how, if at all, are efforts made to critically reflect on the discourse and introduce schemas that may be more in line with sustainability goals.

\section{Engagement Practices}

\section{Diverse Engagement}

While seemingly obvious, it is important to remember that diverse strategies are required to engage diverse stakeholders. First, related to power and to stakeholder participation, participants feeling outnumbered or out of their element may not engage fully. Strategies to attend to this issue include using language and materials that 
reflect different types of people and do not reinforce stereotypes, and providing "safety in numbers" (i.e., ensure individuals won't feel they are a token or outnumbered representative). Second, as MSPs typically privilege participants with verbal facility and comfort speaking in groups, different participation methods (e.g., writing, art, drama) are suggested to help ensure that all participants have an opportunity to be heard (e.g., Himmelman, 1996; Huxham \& Hibbert, 2004; Innes \& Booher, 1999a, 1999b; Lasker \& Weiss, 2003; Sandercock, 2003). Such techniques are further suggested as useful for unleashing creative thinking and/or promoting perspective taking among the full range of participants.

As noted earlier, stories and conversations can be particularly transformative, providing visions or pathways for another way of being. Language shapes the world we see, what we know and do. Thus, it is suggested, "the more hopeful the available vocabularies, the more positive will be the forms of social action and organizing that they support" (Ludema, Cooperrider, \& Barrett, 2001, p. 1021). As Finegold et al. (2002) note, "when we want more collaboration across boundaries, stories of successful collaborations are likely to get us there" (p. 244). Such possibilities are of particular note given the identified difficulty of changing frames, norms, and paradigms. 
Wood and Gray (1991) observe that there is a need to engage "head and heart" in collaborative settings but that we are still learning how to do so. It is suggested here that such engagement occurs in a number of ways. For example, by allowing for diverse ways of knowing (including the extra-rational), attending to the personal and emotional "heart of the matter" (Chile \& Simpson, 2004; Hochachka, 2005; Sandercock, 2003; , 2004, p. 139; Waddock, 1999), recognizing task and socioemotive issues (product and process) as inseparable and inter-related (Fisher \& Freudenburg, 2001; Innes \& Booher, 1999a), and fostering positive emotions such as hope and inspiration through illumination of interdependence and cultivation of a sense of connection, integration, and vision.

While attending to emotion is important for facilitating learning and building trust, participants may have various levels of comfort with "emotional issues." For example, Everett and Jamal (2004) found some participants wanting to quell emotions, while others wanted opportunities to show emotion saying "we can't all be sterilized in our language at all times. We can't always be completely objective" (p. 71). Thus, while diverse strategies of engagement are important, techniques need to be sensitive to context. 


\section{Deep Inquiry}

Reflection and "learning to learn," have not been explicitly addressed in much of the LGI theory or practice (Martin, 2001). Bawden (2005) identifies this absence as a critical design flaw in many MSPs: While "stakeholders often gain a much greater appreciation of complex situations than they previously enjoyed, there is little attempt in any of the approaches to deliberately nurture the development of what might be termed the epistemic status of stakeholders" (p. 174).

Ironically, although multi-stakeholder processes are designed to engage diverse system members in learning and creative problem solving, participants sometimes evidence conflict avoidance behaviors that suppress examination of important issues and system contradictions, thus diminishing the potential of the process to succeed in meeting its goals (Poncelet, 2001a). As Everett and Jamal (2004) note, processes without reflective dialogue may evidence very different outcomes than those that do. Questions asked or avoided shape process effects: "the seeds of change - that is, the things people think and talk about, the things people discover and learn, and the things that inform dialogue and inspire action - are implicit in the very first questions we ask" (Ludema, Cooperrider, \& Barrett, 2001, p. 198). 
Critical reflection and dialogue are suggested for examining habits of mind, assumptions, assertions, and system contradictions. Certain practices, skills, or virtues are suggested (cf, Anderson, Cissna, \& Clune, 2003; Burbules, 1993; Isaacs, 1999; Pruitt, Waddell, Kaeufer, \& Parrot, 2005; Rice \& Burbules, 1992), however, what this looks like may vary with context. As Isaacs (Isaacs, 1999) observes, "in the end dialogue is a quality of being, not a method at all" (p. 75). Further, some reflective practices have been criticized for their neglect of extra-rational and tacit knowing and/or neglect of criticality in a social theory sense (Baumgartner, 2001; Berk \& Burbules, 1999; Dirkx, 1998; Usher, Bryant, \& Johnston, 1997; Welton, 1995). Thus, it is argued that critical reflection and dialogic exploration of assumptions, contradictions, and thought patterns is important and needs to be cultivated, though in ways that honor and engage diverse ways of knowing and attend critically to social issues.

\section{Process Learning}

Related to the topics of inquiry and learning about learning, is the ascription of benefits to critical reflection not just of issues but also of the process itself. Through discussion and written evaluation (anonymous and not), a gauge of the process is taken. While feedback is not guaranteed (e.g., conflict avoidance and/or overload), the 
offer, repeatedly made, confirms that value is placed on safety, equality, and communication. A norm of metacommunication (Enayati, 2002) and process learning is cultivated, building the group's sense of ownership and understanding of collaborative capacity (Brown, Leach, \& Covey, 2004). Further examination of techniques for, and impacts of, such process learning is suggested.

\section{Dominant Habits}

A contradiction arises with the fact that MCLA processes require ample amounts of time, over the long term, in a culture that is "short term and fast moving" (Bunker \& Alban, 1997, p. 223). Time requirements for effective MCLA often clash with the expectations, demands, or constraints of participants and potential participants (Armisted \& Pettigrew, 2004; Chavis, 2001; Everett \& Jamal, 2004; Hemmati, 2002;

Innes \& Booher, 2004; Lebel et al., 2006; Olsson et al., 2006; Pruitt, Waddell, Kaeufer, \& Parrot, 2005; Schafft \& Greenwood, 2003). Capitulating to the doxic sense of time, processes may adhere to restrictive schedules - for example, providing just twenty to sixty minutes for exploration of a complex issue, or lessoning the time and frequency of meetings. Yet accelerating or truncating processes reduces the formal and informal learning spaces that foster transformation of views and 
relationships (Bernard \& Armstrong, 1998; Innes \& Booher, 2004; Lasker \& Weiss, 2003; O'Hara \& Wood, 2005; Poncelet, 2001b; Schusler, Decker, \& Pfeffer, 2003).

This tension is exacerbated by the fact that much of the product from MCLA is process: many effects are intangible and secondary, yet pressure is great for tangible, material outputs. On one hand, there is a need to accommodate participant diversity that includes individuals focused on "action." On the other hand, such a focus may be inappropriate for some MCLA processes. As Marsick and Kasl (1997) note, “when groups perceive themselves to be created to address a particular task, the pressure of task accomplishment makes group learning difficult" (p. 4).

Clarity regarding participation and anticipated outcomes is suggested so that participants' expectations for the process are reasonable, ownership is fostered, and disappointment and "dialogue fatigue" are avoided (Margerum, 1999; Oels, 2002; Polanyi, 2001; Pruitt, Waddell, Kaeufer, \& Parrot, 2005; Schusler, Decker, \& Pfeffer, 2003; J. F. Warner, 2006). "Outcome advocacy" (Alexander et al., 2003) is suggested in order to help participants recognize process related outcomes that may be overlooked (Imel \& Stein, 2003; Imel \& Zengler, 2002; Kilpatrick, Bell, \& Falk, 1999; Pruitt, Waddell, Kaeufer, \& Parrot, 2005; Schafft \& Greenwood, 2003). Outcome advocacy to funders and managers is also identified as important so that this foundational work can be appropriately valued and invested in (Gilchrist, 2000). 
Finally, while collaborative capacity developed in MCLA processes is suggested to transfer to other situations (Hibbert \& Huxham, 2005; Poncelet, 2001b; Simonin, 1997), capacity demonstrated within the process has also been seen to evaporate outside the process (Isaacs, 1999). A dilemma exists in that many of the practices most likely to promote effective learning and relationship building often are resisted within the dominant culture and, even when achieved within the process, may be difficult to translate or incorporate back into "daily life." Further exploration is warranted of interactions between dominant cultural habits and process outcomes, as well as techniques to frame time and outcomes in ways to support MCLA effectiveness.

\section{Referent Organization}

Referent or bridging organizations play an important role in domain development facilitating system appreciation, identification of common ground, knowledge generation and transfer, and development of social capital (Agranoff \& McGuire, 2001; Folke, Hahn, Olsson, \& Norberg, 2005; Hahn, Olsson, Folke, \& Johnsson, 2006; Imperial, 2005; McCann, 1983; Pasquero, 1991; Trist, 1983). Surprisingly little 
attention has been paid to this topic and, as discussed below, significant questions exist regarding direction and structure for such organizations.

Referent organizations can take one of a number of forms (Imperial, 2005; McCann, 1983; Trist, 1983). Further, permeable boundaries and changing context make collaboration dynamic; thus, structuring is on-going and forms may change over time (Gray, 1985; Thacher, 2004). As Trist (1983) observed, a delicate balance is required to provide enough structure to foster the vision, norms, and coordinating channels that support domain regulation without being so centralized, hierarchical, and bureaucratic as to render the organization ineffective or, even worse, to exacerbate the situation. Trist (1983) suggests that referent organizations engage in "regulation as distinct from operation - operations are the business of the constituent organizations" (p. 275). Thus, the job of the referent organization becomes one of cultivating and holding the vision, providing infrastructure support, and fostering relationships and norms.

Characteristics of complexity, plurality, and uncertainty suggest a networked or distributed response, however, the concept of self-organization has limits. As Senge and Scharmer (2001) note "self-organizing' cannot always be left to itself" (p. 245). The very point of addressing underorganized domains is that system appreciation and regulative mechanisms have not emerged. Structures, resources, and supports are necessary to enable the system to recognize itself as a system and behave adaptively. 
Further, it is naïve to think that by simply "getting them in the room" individuals will succeed in defining and implementing action agendas. A number of barriers may stand in the way including a lack of resources and authority for action, or differences in organizational tempo, agenda, personality, turf, or trust.

At the same time, Polanyi (2001) and Schafft and Greenwood (2003) identified tensions between the self-organization principle and a design that defines common ground and priority actions. How, if at all, are decisions made regarding what programs should move forward? Who ensures that programs are not working at crosspurposes or are of sufficient quality? Ambiguity identified as useful when defining missions and goals (Eisenberg \& Witten, 1987; Huxham \& Vangen, 2000a; Turcotte \& Pasquero, 2001) may be untenable as the "devil in the detail" emerges.

Issues also exist regarding the referent organization itself taking on projects. Projects are often suggested as important for creating a sense of identity to the organization and providing a sense of success, accomplishment, and empowerment. Further, projects may be seen as addressing a critical identified gap. There are examples of successful project development ${ }^{2}$ by referent organizations (Folke, Hahn, Olsson, \& Norberg,

\footnotetext{
${ }^{2}$ Sometimes with the project remaining in the fold of the referent organization and sometimes being "spawned and shed" (Westley \& Vredenburg, 1997).
} 
2005; Imperial, 2005; Westley \& Vredenburg, 1997), though clearly projects are not always appropriate and/or successful.

Issues also exist with respect to identity and administration of referent organizations. For example, being housed within an existing organization may afford resources, legitimacy, and stability but hold the potential for cooptation or alienation of certain stakeholders. Cultivating its own identity, the referent organization needs to ensure that members or partners share that identity and maintain a sense of ownership. Related to outcome advocacy, acquisition of resources may be a challenge, particularly when the organization is focused, appropriately, on "soft" capacity building.

Finally, given the scale and horizon of the issues being addressed, it is helpful to conceptualize referent organizations and processes as polycentric, multi-layered, emergent, and on-going. Anchored in a larger, evolutionary story, they cannot be understood in isolation, nor perceived as one-off events. Coordination of organizations and events across space and time must also be attended to (McCann, 1983; Waddell, 2005). Understanding regarding referent organization roles, structures, and inter-relationships would benefit from further research on the subject. 


\section{Measurement}

MCLA processes are notoriously difficult to evaluate and compare (Bunker \& Alban, 1997; El Ansari, Phillips, \& Hammick, 2001). Such processes are complex and indeterminate. Factors affecting their result begin prior to the process, and cannot all be known. Embedded in a larger context, it is impossible to identify and attribute all of the effects. Individual, group, and societal levels interact with each other in nonlinear and indeterminate ways. Participants themselves may not be aware of effects let alone persons or organizations impacted more distally (e.g., a new program is initiated and people do not know that the idea originated with a staff persons' attendance to a MCLA event). Transformation is difficult to measure and, though sometimes seemingly small, "may well serve as the foundation for future large-scale improvements..." (Poncelet, 2001b, p. 297). As Rossing (1991) notes, "experience and the learning that occurs through experience are continuous processes with each event flowing into the next and relating to countless other events" (p. 51).

This research supports the contention that conventional evaluation methods focusing on agreements and implementation may be inappropriate for evaluation of collaborative endeavors (Connick \& Innes, 2003; El Ansari, Phillips, \& Hammick, 2001; Imperial, 2005; Innes \& Booher, 1999a; Margerum, 2002). For example, one project may "succeed" in achieving an agreement though the agreement is superficial 
and conflict soon reappears, while another project may "fail" to reach an agreement though facilitate learning, networks, and trust that lead to new arrangements in the future. Further, a lack of implementation may occur not because the collaborative process failed but because of a budget shortfall or change in circumstances (Innes \& Booher, 1999a).

Design for each MSP is unique, as are participant and environmental characteristics and micro-processes. At the same time, while each process can only be designed and understood in context, case comparison provides indications regarding what reasonably to expect, factors likely to foster or inhibit success, caveats and dilemmas, and potential strategies.

\section{Comparability and Appropriate Use of Processes}

Related to issues of measurement are questions regarding comparability of various multi-stakeholder processes and appropriate use of specific processes in a given situation. Attempts to categorize multi-stakeholder methods have begun to emerge. For example, Bunker and Albans (1997) categorize twelve large group intervention methods by one of three primary functions: future creating, work design, and whole systems participative work. Pioneers of Change Associates (2006) assess ten dialogue 
methods with respect to their suitability depending on eleven potential process purposes $^{3}$ and with respect to seven context factors. ${ }^{4}$ Holman, Devane, and Cady (2007) consider sixty-one change methods according to seven characteristics (i.e., purpose, system type, event size, duration, periodicity/cycle, practitioner preparation, and special resource needs). All of the authors address the difficulty of categorizing methods as well as the potential for method mixing and adaptation.

Where MCLA processes are appropriate, which methods can most profitably be applied? This is a daunting question not only because the methods are numerous and constantly evolving, but because each is suited to different circumstances and results vary to some degree with the particulars of a given case (Bunker \& Alban, 1997; Griffin \& Purser, In Press; Holman, Devane, \& Cady, 2007, Pioneers of Change Associates, $2006 \# 501$ ). Despite these idiosyncrasies, research is useful for evaluating claims associated with specific methods and suggesting important features, best practices, and caveats. Further, such research is suggested to benefit from dialogue between academic and practitioner communities as well as diverse disciplines (e.g., Armisted \& Pettigrew, 2004; Bunker, Alban, \& Lewicki, 2004; Huxham, 2003; Nexus For Change, n.d.). Additional research on multi-stakeholder processes, written up

\footnotetext{
${ }^{3}$ Generate awareness, problem-solve, build relationships, share knowledge and ideas, innovate, shared vision, capacity building, personal development/leadership, dealing with conflict, strategy/action planning, decision-making.

${ }^{4}$ Complexity, conflict, group size, microcosm or peer focus, power and class diversity, generational and cultural diversity, facilitator training requirements.
} 
with sufficient case detail, will enhance understanding of these processes and facilitate comparison among and between methods.

\section{Social Change and Sustainability}

MCLA processes have been suggested as useful for addressing complex, plural, and uncertain issues. Can they also be productively employed in support of social change and sustainability? A qualified, cautiously optimistic "yes" is provided, though a number of issues must be considered.

As discussed earlier, dominant discourses and habits provide a formidable challenge to the promise of MCLA. Everett and Jamal (2004) observed, "it may be fair to say that much of the needed changes will be thwarted by the sheer power of the doxic understanding that characterizes this field" (p. 71). Serious attention needs to be given to MCLA design considerations so that system contradictions with respect to sustainability are surfaced. Further, as research on behavior change and proenvironmental behavior identifies a number of factors beyond issue awareness to be important, attention should also be given to the ways MCLA process can support action that aligns with articulated sustainability goals. 
A sense of "magic" is often attributed to multi-stakeholder processes by participants (Bunker \& Alban, 1997; Kasl \& Yorks, 2002; Phillips \& Huzzard, 2007; Poncelet, 2001b). The surprise regarding discovery of common ground and an ability to learn and work together suggests that such interactions, and the embedded practices and skills, are out of the norm. One implication is that these processes cultivate a capacity for new ways of knowing and being together. Gersick's (1991) cross-disciplinary examination of change identifies "three barriers to radical change in human systems: cognition, motivation, and obligation" (p. 18). While other barriers may exist, MCLA processes address these three barriers to social change to the degree that they enhance our ability to understand sustainability, inspire care and a sense of capacity, and foster networks and norms. Thus, while deep structural barriers may inhibit the ability of MCLA processes to facilitate social change toward sustainability, MCLA processes themselves may work to productively alter said structures to be more supportive of sustainability goals. In the end, we must neither underestimate the power of deep structures and habits nor the power of engagement to change them.

Another challenge relates to the fact that sustainability remains an elusive concept. While diverse stakeholders may agree that they want environmental stewardship, economic opportunity, and social justice, there is a shortage of detail as to what that looks like and how to measure it. Tensions emerge with this not knowing. For example, at CFM's February 2003 event on regional food economies, presenters gave 
illustrations of sustainable food systems that featured processed and packaged goods and overseas exports - examples that were perceived by some participants as noble efforts to keep producers in business and by others as exemplifying a broken, industrial, energy intensive food system. Noted one interviewee, "One of the challenges we've encountered with CFM is the idea of incorporating the sustainability element. Sure we want to have lots of local food entrepreneurs, but if they're making GMO cheesy-poofs, then that's not really what we want." Ambiguity surrounding the concept of sustainability provides a challenge to MCLA processes, however the explicit learning dimension of the process itself provides a mechanism to adaptively address this ambiguity over time.

While MCLA provides a tool for promoting social change and sustainability, it cannot be seen as a panacea, cure all, or silver bullet. Nor should it be seen as appropriate to every situation (Calton \& Payne, 2003; Connick \& Innes, 2003; Daniels \& Walker, 1996; Hardy \& Phillips, 1998; Huxham, 2003; Pruitt, Waddell, Kaeufer, \& Parrot, 2005; J. Warner, 2005). Positive assessments must be tempered with realistic expectations (Turcotte \& Pasquero, 2001). MSPs, it has been observed, are replete with paradox (Calton \& Payne, 2003; Huxham \& Vangen, 2000a; Ospina \& SazCarranza, 2005). For example, the very diversity required for processes to work makes engagement a challenge. Social networks are important for getting people in the room, but are difficult to cultivate until you get people in the room. It's difficult to 
have trust when there is no history, yet having no history or a history that includes "baggage" may inhibit trust. The process is emergent yet needs to be defined enough to recruit people in. Ambiguity accommodates diversity, but may hinder progress. Process work is essential but participants often resist it. Projects are viewed as important but may be the wrong focus. Collaboration is essential but tensions exist regarding integration and differentiation. Communication is essential but participants often don't communicate. Time for relationship building and contemplation is vital but participants don't always allocate the time. Participation yields appreciation for the process, yet without that appreciation many individuals won't participate. Indeed, given the barriers and contradictions to MCLA success it is almost surprising that these processes work at all. But they have. Which leads to the cautiously optimistic, qualified "yes" regarding their employment in pursuit of social change and sustainability.

As Dukes (1996) notes, despite formidable challenges to developing forums that cultivate a sense of relatedness, "in contemporary society, where the legacy to posterity and the interdependence of individual, community, and society are so much at risk, there is little choice" (p. 170). Challenges associated with multi-stakeholder collaborative learning and action processes in support of social change and sustainability are substantial, but prospects for achievement of those goals without such processes seem slim at best. As one interviewee in this case noted: 
When you have an issue where there is a lack of consciousness about it and when it fundamentally has a lot of moving parts, most of which traditionally are divided into very disparate areas of focus, the value and impact of a process like this is great. Because I don't think it is the kind of issue that can be easily addressed through any other approach.

\section{Coda}

In $2001 \mathrm{I}$ began a journey of service scholarship that aimed to support efforts to promote sustainable regional food systems and contribute to understanding about multi-stakeholder processes designed to build shared understandings and agreements facilitative of more sustainable communities. Specifically, I sought to increase understanding about the design and effects of multi-stakeholder collaborative learning and action processes.

My close association with the process (convener and manager) may suggest to some that I might be inclined to provide (overly) favorable reviews. On the contrary. As I began my analysis I viewed the endeavor as a bit of a failure given that the collaborative alliance had ceased to exist. It was only as I engaged with the data and the literature that I began to understand what had transpired and appreciate the process' successes and failures. 
As this stage of my journey comes to an end, I pause to take stock. This research has helped to clarify what reasonably can be expected from MCLA processes and how best to design them. Understanding regarding how and why MCLA processes work has been enhances, as has understanding about relationships between particular types of MCLA processes (i.e., large group interventions and referent organizations) and domain development. A healthy respect for the challenges of MCLA processes has been cultivated, as has caution about their inappropriate or ill designed use. Questions about MCLA processes remain to be addressed, yet I conclude with modest expectations and a renewed, albeit cautious, optimism for their application to sustainability and social change. I turn to the words of Daniel Kemmis (1990, p. 119), former Mayor of Missoula and Speaker and Minority Leader of the Montana House of Representatives, and am reminded why I began this journey, and why this work is but one stage in a longer, collective, journey.

There are not many rivers, one for each of us,

but only this one river, and if we all want to stay here, in some kind of relation to the river, then we have to learn, somehow, to live together. 


\section{TERMINAL REFERENCE LIST}

Abram, S. (2000). Planning the public: some comments on empirical problems for planning theory. Journal of Planning Education and Research, 19(4), 351357.

Ackoff, R. (1974). Redesigning the future: a systems approach to societal problems. New York, NY: John Wiley \& Sons.

Adam, F., \& Borut, R. (2003). Social capital: recent debates and research trends. Social Science Information, 42(2), 155-183.

Adler, P. S., \& Kwon, S.-W. (2002). Social capital: prospects for a new concept. Academy of Management Review, 27(1), 17-40.

Adlong, W. (2006). Framing participatory inquiry in terms of 'reflexivity'. Paper presented at the Australia Pacific Extension Network International Conference, Beechworth, Victoria, Australia.

Agranoff, R., \& McGuire, M. (2001). Big questions in public network management research. Journal of Public Administration Research and Theory, 11(3), 295326.

Aldenderfer, M. S., \& Blashfield, R. K. (1984). Cluster analysis. Beverly Hills, CA: Sage Publications.

Alexander, D. (1999). Planning as learning: sustainability and the education of citizen activists. Environments, 27(2), 79-87.

Alexander, E. R. (1993). Interorganizational coordination: theory and practice. Journal of Planning Literature, 7(4), 328-343.

Alexander, J. A., Comfort, M. E., Weiner, B. J., \& Bogue, R. (2001). Leadership in collaborative community health partnerships. Nonprofit Management and Leadership, 12(2), 159-175.

Alexander, J. A., Weiner, B. J., Metzger, M. E., Shortell, S. M., Bazzoli, G. J., Hasnain-Wynia, R., et al. (2003). Sustainability of collaborative capacity in community health partnerships. Medical Care Research and Review, 60(4), 130S-160S.

Ali, B. (2001). Multistakeholder collaboration outcomes in environmental voluntary initiatives: The case of A.R.E.T. initiative. Concordia University, Montreal.

Alkire, S. (2002). Dimensions of human development. World Development, 30(2), 181-205.

Alvarez, C. L., Diemer, J. A., \& Stanford, M. L. (1999). Participative strategic planning for sustainable community forestry in Chihuahua, Mexico. Culture and Agriculture, 21(2), 19-28.

Andersen, M. S., \& Massa, I. (2000). Ecological modernization: origins, dilemmas and future directions. Journal of Environmental Policy and Planning, 2(4), 337-345.

Anderson, R. (n.d.). On dialogue and its difficulties. Unpublished manuscript, Vancouver, BC. 
Anderson, R., Cissna, K. N., \& Clune, M. K. (2003). The rhetoric of public dialogue. Communication Research Trends, 22 (1), 3-33.

Argyris, C. (2000, July-August 1994). Good communication that blocks learning. Harvard Business Review, 77-85.

Argyris, C., \& Schon, D. A. (1978). Organizational learning: a theory of action perspective. Reading, MA: Addison Wesley.

Armisted, C., \& Pettigrew, P. (2004). Effective partnerships: building a sub-regional network of reflective practitioners. The International Journal of Public Sector Management, 17(7), 571-585.

Armstrong, J. (2006). Let us begin with courage. Education for Sustainability Retrieved August 1, 2006, 2006, from http://www.ecoliteracy.org/publications/pdf/jarmstrong_letusbegin.pdf.

Arnstein, S. R. (1969). A ladder of citizen participation. Journal of the American Planning Association, 35(4), 216-224.

Babbie, E. (1983). Practicing social research. Belmont, CA: Wadsworth Publishing Company.

Bacher, J. (2002). Cluster analysis. from http://www.soziologie.wiso.unierlangen.de/koeln/script/script.pdf.

Banathy, B., \& Jenlink, P. M. (2005). Dialogue as a means of collective communication. New York, NY: Kluwer Academic/Plenum Publishers.

Banathy, B. H. (1996). Designing social systems in a changing world. New York, NY: Plenum Press.

Bardach, E. (2001). Developmental dynamics: collaboration as an emergent phenomenon. Journal of Public Administration Research and Theory, 11(2), 149-164.

Barnes, M., Sullivan, H., \& Matka, E. (2004). The development of collaborative capacity in Health Action Zones: a final report from the national evaluation. Birmingham, UK: The University of Birmingham.

Barraket, J. (2005). Enabling structures for coordinated action: community organizations, social capital, and rural community sustainability. In A. Dale \& J. Onyx (Eds.), A dynamic balance: Social capital and sustainable community development (pp. 71-86). Vancouver, BC: UBC Press.

Baruch, Y. (1999). Response rate in academic studies: a comparative analysis. Human Relations, 52(4), 421-436.

Bateson, G. (1972). Steps to an ecology of mind. New York, NY: Ballantine.

Baumgartner, L. M. (2001). An update on transformational learning. New Directions for Adult and Continuing Education, 89, 15-24.

Bawden, R. (2005). A commentary on three papers. Agriculture and Human Values, 22(2), 169-176.

Bean, W. E. (2000). Community development and adult education: locating practice in its roots. New Directions for Adult and Continuing Education, 85, 67-76.

Becker, L. A. (1999). Assumption testing for ANOVA. 2005, from http://web.uccs.edu/lbecker/spss80/explore2.htm 
Bell, S. J., Whitwell, G., J. , \& Lukas, B. A. (n.d.). Organisational learning research: taking stock of the underlying theoretical views. Unpublished manuscript, Melbourne, Australia.

Bellah, R. N., Madsen, R., Sullivan, W. M., Swidler, A., \& Tipton, S. M. (1996). Habits of the heart (2nd ed.). Berkeley, CA: University of California Press.

Benn, S., \& Onyx, J. (2005). Negotiating interorganizational domains: the politics of social, natural, and symbolic capital. In A. Dale \& J. Onyx (Eds.), A dynamic balance: Social capital and sustainable community development (pp. 87104). Vancouver, BC: UBC Press.

Bentrup, G. (2001). Evaluation of a collaborative model: a case study analysis of watershed planning in the intermountain west. Environmental Management, 27(5), 739-748.

Bentz, V. M., \& Shapiro, J. J. (1998). Mindful inquiry in social research. Thousand Oaks, CA: SAGE Publications.

Berk, R., \& Burbules, N. C. (1999). Critical thinking and critical pedagogy: relations, differences, and limits. In T. S. Popkewitz \& L. Fendler (Eds.), Critical Theories in Education. New York, NY: Routledge.

Bernard, A. K., \& Armstrong, G. (1998). Learning and policy integration. In J. Schnurr \& S. Holtz (Eds.), The cornerstone of development (pp. 45-71). Boca Raton, US: CFC Press/Lewis Publishers.

Bettencourt, B. A. (1996). Grassroots organizations: recurrent themes and research approaches. Journal of Social Issues, 52(1), 207-220.

Bhattacharyya, J. (2004). Theorizing community development. Journal of the Community Development Society, 34(2), 5-34.

Blaug, R. (1999). Democracy real and ideal: discourse ethics and radical politics. Albany, NY: SUNY Press.

Block, P. (1993). Stewardship: choosing service over self-interest. San Francisco, CA: Berrett Koehler.

Bohm, D. (1996). On dialogue. NY: Routledge.

Booher, D. E., \& Innes, J. E. (2002). Network power in collaborative planning. Journal of Planning Education and Research, 21, 221-236.

Boud, D., Keogh, R., \& Walker, D. (Eds.). (1985). Reflection: turning experience into learning. New York, NY: RoutledgeFalmer.

Bouwen, R., \& Taillieu, T. (2004). Multi-party collaboration as social learning for interdependence: developing relational knowing for sustainable natural resource management. Journal of Community and Applied Social Psychology, 14, 137-153.

Bowers, C. A. (1994). Educating for an ecologically sustainable culture: rethinking moral education, creativity, intelligence, and other modern orthodoxies. Albany, NY: SUNY Press.

Bradbury, H. (2001). Dynamics of dialogic capital in interorganizational collaboration. Sprouts: Working Papers on Information Environments, Systems and Organizations, 1, 1-19.

Bradshaw, T. K. (2000). Complex community development projects: collaboration, 
comprehensive programs, and community coalitions in complex society. Community Development Journal, 35(2), 133-145.

Bramson, R. A., \& Buss, T. (2002). Methods for whole system change in public organizations and communities: An overview of the issues. Public Organization Review: A Global Journal, 2, 211-221.

Briggs, X. d. S. (2004). Social capital: easy beauty or meaningful resource? Journal of the American Planning Association, 70(2), 151-158.

Brookfield, S. (1987). Developing critical thinkers: challenging adults to explore alternative ways of thinking and acting. San Francisco, CA: Jossey-Bass.

Brookfield, S. (1994). Tales from the dark side: a phenomenography of adult critical reflection. International Journal of Lifelong Education, 19(3), 203-216.

Brooks, J. J., Bujak, A. N., Champ, J. G., \& Williams, D. R. (2006). Collaborative capacity, problem framing, and mutual trust in addressing the wildland fire social problem: an annotated reading list (No. General Technical Report RMRS-GTR-182). Fort Collins, CO: Rocky Mountain Research Station

Brooks, R., \& B., M. A. (2000). Learning communities and community development: describing the process. Learning Communities: International Journal of Adult and Vocational Learning, 1, 1-15.

Brown, L. D. (1980). Planned change in underorganized systems. In T. G. Cummings (Ed.), Systems theory for organization development (pp. 181208). New York, NY: John Wiley \& Sons.

Brown, L. D. (1991). Bridging organizations and sustainable development. Human Relations, 44(8), 807-831.

Brown, L. D. (1993). Development bridging organizations and strategic management for social change. Advances in Strategic Management, 9, 381-405.

Brown, L. D., Leach, M., \& Covey, J. G. (2004). Organization development for social change (No. Working Paper Number 25). Cambridge, MA: The Hauser Center for Nonprofit Organizations and the Kennedy School of Government, Harvard University.

Brown, S. R. (1980). Political subjectivity: applications of $Q$ methodology in political science. New Haven, CT: Yale University Press.

Brown, S. R. (1993). A primer on Q methodology. Operant Subjectivity, 16, 91-138.

Brown, S. R. (2006, November 10). Basic Q questions. from http://listserv.kent.edu/archives/q-method.html

Bryson, J. M., \& Anderson, S. R. (2000). Applying large-group interaction methods in the planning and implementation of major change efforts. Public Administration Review, 60(2), 143-162.

Buber, M. (1970). I and Thou (W. Kaufmann, Trans.). NY: Charles Scribners' Sons.

Bunker, B. B., \& Alban, B. T. (1997). Large group interventions: engaging the whole system for rapid change. San Francisco, CA: Jossey-Bass.

Bunker, B. B., \& Alban, B. T. (2005). Introduction to the special issue on large group interventions. The Journal of Applied Behavioral Science, 41(1), 9-14.

Bunker, B. B., Alban, B. T., \& Lewicki, R. J. (2004). Ideas in currency and OD practice: has the well gone dry? The Journal of Applied Behavioral Science, 
40(4), 403-422.

Burbules, N. (1993). Dialogue in teaching: theory and practice. New York, NY: Teachers College Press.

Burbules, N., \& Rice, S. (1991). Dialogue across differences: continuing the conversation. Harvard Educational Review, 61(4), 393-416.

Bushe, G. R. (2005). When is Appreciative Inquiry transformational? A metacase analysis. The Journal of Applied Behavioral Science, 41(2), 161-181.

Caffarella, R., \& Merriam, S. (1999). Perspectives on adult learning: framing our research. Paper presented at the AERC.

Calton, J. M., \& Payne, S., L. (2003). Coping with paradox. Business and Society, $42(1), 7-41$.

Carifo, J. (2005). Towards a standard integrated information processing/cognitive model of learning. Paper presented at the Eighth Annual International History, Philosophy and Science Teaching Conference, Leeds, England.

Carkhuff, M. H. (1999). Enemies or learning partners? The interplay of power and learning in a cross boundary work group. Paper presented at the 40th Annual Adult Education Research Conference, Northern Illinois University, DeKalb, Illinois.

Cartwright, D., \& Zander, A. (Eds.). (1968). Group dynamics: research and theory. New York: NY: Harper and Row.

Cash, D. W., Clark, W. C., Alcock, F., Dickson, N. M., Eckley, N., Guston, D. H., et al. (2003). Knowledge systems for sustainable development. Proceedings of the National Academy of Sciences, 100(14), 8086-8091.

Cayer, M. (2005). The five dimensions of the practice of Bohm's Dialogue. In B. Banathy \& P. M. Jenlink (Eds.), Dialogue as a means of collective communication (pp. 161-192). New York, NY: Kluwer Academic/Plenum Publishing.

Cervero, R. M., \& Wilson, A., L. (Eds.). (2001). Power in practice: adult education and the struggle for knowledge and power in society. San Francisco, $\mathrm{Ca}$ : Jossey-Bass.

Chavis, D. M. (2001). The paradoxes and promise of community coalitions. American Journal of Community Psychology, 29(2), 309-319.

Checkland, P. (2000). Soft systems methodology: a thirty year retrospective. Systems Research and Behavioral Science, 17, S11-S58.

Chile, L. M., \& Simpson, G. (2004). Spirituality and community development: exploring the link between the individual and the collective. Community Development Journal, 39(4), 318-331.

Clark, M. C. (1993). Transformational learning. New Directions for Adult and Continuing Education, 57, 47-56.

Clarke, N. (2005). Transorganizational development for network building. The Journal of Applied Behavioral Science, 41(1), 30-46.

Clover, D. E., \& Hall, B. L. (2000). In search of social movement learning: the growing jobs for living project. Toronto: ON: University of Toronto.

Connick, S. (2003). The use of collaborative processes in the making of California 
water policy: The San Francisco Estuary Project, the CALFED Bay-Delta Program, and the Sacramento Area Forum. UC Berkeley, Berkeley, CA.

Connick, S., \& Innes, J. E. (2003). Outcomes of collaborative water policy making: applying complexity thinking to evaluation. Journal of Environmental Planning and Management, 46(2), 177-197.

Cranton, P. (1992). Working with adult learners. Middletown, OH: Wall \& Emerson, Inc.

Cranton, P. (1996). Types of group learning. New Directions for Adult and Continuing Education, 71, 25-32.

Cranton, P. (Ed.). (1997). Transformative learning in action: insights from practice (Vol. 74). San Francisco, CA: Jossey Bass.

Creswell, J. (1998). Qualitative inquiry and research design: choosing among five traditions. Thousand Oaks: Sage.

Crosby, B. C., \& Bryson, J. M. (2005). Leadership for the common good: tackling public problems in a shared-power world (2nd ed.). San Francisco, CA: Jossey-Bass.

Crosby, B. C., \& Bryson, J. M. (2005). A leadership framework for cross-sector collaboration. Public Management Review, 7(2), 177-201.

Cross, R., Borgatti, S. P., \& Parker, A. (2002). Making invisible work visible: using social network analysis to support strategic collaboration. California Management Review, 44(2), 25-45.

Crowther, J., \& Shaw, M. (1997). Social movements and the education of desire. Community Development Journal, 32(3), 266-279.

Culbert, S., Elden, J., McWhinney, W., Schmidt, W., \& Tannenbaum, B. (1972). Trans-organizational praxis: a search beyond organization development. International Associations, XXIV(10), 470-473.

Cummings, T. G. (1984). Transorganizational development. In B. M. Staw \& L. L. Cummings (Eds.), Research in organizational behavior (Vol. 6, pp. 367 422). Greenwich, CT: JAI Press Inc.

Dahlberg, K. (2001). Democratizing society and food systems: or how do we transform modern structures of power? Agriculture and Human Values, 18, 135-151.

Dale, A., \& Onyx, J. (2005). A dynamic balance: social capital and sustainable community development. Vancouver, BC: UBC Press.

Daniels, S. E., \& Walker, G. B. (1996). Collaborative learning: improving public deliberation in ecosystem-based management. Environmental Impact Assessment Review, 16, 71-102.

Davies, A. R. (2002). Power, politics and networks: shaping partnerships for sustainable communities. Area, 34(2), 190-203.

Davis, M. H., Laura, C., Smith, A., \& Luce, C. (1996). Effect of perspective taking on the cognitive representation of persons: a merging of self and other. Journal of Personality and Social Psychology, 70(4), 713-726.

Davis, S. M. (1996). Environmental politics and the changing context of interest group organization. The Social Science Journal, 33(4), 1-14. 
de Souza Briggs, X. (1998). Doing democracy up-close: culture, power, and communication in community building. Journal of Planning Education and Research, 18(1-13).

DeLind, L. B., \& Ferguson, A. E. (1999). Is this a women's movement? The relationship of gender to community supported agriculture in Michigan. Human Organization, 58(2), 190-200.

Denzin, N., \& Lincoln, Y. S. (2000). Handbook of qualitative research (Second ed.). Thousand Oaks, CA: Sage Publications.

Diani, M. (2001). Social capital as social movement outcome. In B. Edwards, M. W. Foley \& M. Diani (Eds.), Beyond Tocqueville: Civil society and the social capital debate in comparative perspective (pp. 207-218). Hanover, NH: Tufts University.

Diduck, A., Bankes, N., Douglas, C., \& Derek, A. (2005). Unpacking social learning in social-ecological systems: case studies of polar bear and narwhal management in northern Canada. In F. Berkes, R. Huebert, H. Fast, M. Manseau \& A. Diduck (Eds.), Breaking Ice: Renewable Resource and Ocean Management in the Canadian North. Calgary, Canada: University of Calgary Press.

Diduck, A., Sinclair, A. J., \& Shymko, R. (2000). Congruence of barriers to public involvement in local climate change initiatives and environmental assessment processes. Paper presented at the Climate Change Communication Conference. Retrieved.

Dietz, T., Ostrom, E., \& Stern, P. C. (2003). The struggle to govern the commons. Science Editor, 302(5652), 1907-1912.

Dirkx, J. M. (1998). Transformative learning theory in the practice of adult education: an overview. Journal of Lifelong Learning, 7, 1-14.

Division of Instructional Innovation and Assessment. (2006). Analyzing, interpreting, and reporting survey data for publication. Retrieved October 16,2006 , from http://www.utexas.edu/academic/diia/assessment/iar/how to/interpreting dat a/surveys/publication.php

Dokecki, P. R., Newbrough, J. R., \& O'Gorman, R. T. (2001). Toward a communityoriented action research framework for spirituality: community psychological and theological perspectives. Journal of Community Psychology, 29(5), 497518.

Dollahite, J. S., Nelson, J. A., Frongillo, E. A., \& Griffin, M. R. (2005). Building community capacity through enhanced collaboration in the farmers market nutrition program. Agriculture and Human Values, 22(3), 339-354.

Dooley, K. J. (1997). A complex adaptive systems model of organization change. Nonlinear Dynamics, Psychology, and Life Sciences, 1(1), 69-97.

Drennon, C. (2002). Negotiating power and politics in practitioner inquiry communities. New Directions for Adult and Continuing Education, 95, 6167.

Dryzek, J. S. (1990). Discursive democracy: politics, policy, and political science. 
New York, NY: Cambridge University Press.

Dukes, F. (1996). Resolving public conflict: transforming community and governance. New York, NY: St. Martin's Press.

Dunlap, R., Van Liere, K., Mertig, A., \& Jones, R. E. (2000). Measuring endorsement of the New Ecological Paradigm: a revised NEP scale. Journal of Social Issues, 56(3), 425-442.

Eden, C., \& Huxham, C. (2001). The negotiation of purpose in multi-organizational collaborative groups. Journal of Management Studies, 38(3), 373-391.

Edmonson, A. (1999). Psychological safety and learning behavior in work teams. Administrative Science Quarterly, 44(4), 350-383.

Ehrenfeld, J. R. (2000). Colorless green ideas sleep furiously: is the emergence of "sustainable" practices meaningful? Reflections, 1(4), 34-47.

Eisenberg, E. M., \& Witten, M. G. (1987). Reconsidering openness in organizational communication. Academy of Management Review, 12(3), 418-426.

El Ansari, W., Phillips, C. J., \& Hammick, M. (2001). Collaboration and partnerships: developing the evidence base. Health and Social Care in the Community, 9(4), 215-227.

Ellis, J. H. M., \& Kiely, J. A. (2000). Action inquiry strategies: Taking stock and moving forward. Journal of Applied Management Studies, 9(1), 83-94.

Ellsworth, E. (1989). Why doesn't this feel empowering? Working through the repressive myths of critical pedagogy. Harvard Educational Review, 59(3).

Ely, M., Anzul, M., Friedman, T., Garner, D., \& McCormack-Steinmetz, A. (1991). Doing qualitative research: circles within circles. Philadelphia, PA: The Falmer Press.

Enayati, J. (2002). The research: effective communication and decision-making in diverse groups. In M. Hemmati (Ed.), Multi-stakeholder Processes for Governance and Sustainability (pp. 73-95). Sterling, VA: Earthscan Publications Ltd.

English, L. M., \& Gillen, M. A. (Eds.). (2000). Addressing the spiritual dimensions of adult learning: what educators can do. San Francisco, CA: Jossey-Bass.

Erlandson, D., Harris, E., Skipper, B., \& Allen, S. (1993). Doing naturalistic inquiry: a guide to methods. London: SAGE Publications.

Eshuis, J., \& Stuiver, M. (2005). Learning in context through conflict and alignment: farmers and scientists in search of sustainable agriculture. Agriculture and Human Values, 22(2), 137-148.

Ettling, D. (2006). Ethical demands of transformational learning. New Directions for Adult and Continuing Education, 109, 59-67.

Everett, J., \& Jamal, T. B. (2004). Multistakeholder collaboration as symbolic marketplace and pedagogic practice. Journal of Management Inquiry, 13(1), 57-78.

Falk, I., \& Kilpatrick, S. (2000). What is social capital? a study of interaction in a rural community. Sociologia Ruralis, 40(1), 87-110.

Ferguson, R., F., \& Stoutland, S. E. (1999). Reconceiving the community development field. In R. F. Ferguson \& W. T. Dickens (Eds.), Urban 
problems and community development. Washington, DC: Brookings Institution Press.

Finegold, M. A., Holland, B. M., \& Lingham, T. (2002). Appreciative Inquiry and public dialogue: an approach to community change. Public Organization Review: A Global Journal, 2, 235-252.

Finger, M., \& Kilcoyne, J. J. (1995). Learning our way out: indicators of social environmental learning. In T. C. Tryzna \& J. K. Osborn (Eds.), A sustainable world: defining and measuring sustainable development. London: Earthscan.

Finnerty, M. (1999). Understanding the experience of large group processes: how do people participate collaboratively in creating a vision for their common future? Unpublished Ph.D. dissertation, The Fielding Institute.

Fisher, D. R., \& Freudenburg, W. R. (2001). Ecological Modernization and its critics: assessing the past and looking toward the future. Society and Natural Resources, 14(8), 701-709.

Flood, R. L. (2001). The relationship of 'systems thinking' to action research. In P. Reason \& H. Bradbury (Eds.), Handbook of action research: participative inquiry and practice (pp. 133-144). Thousand Oaks, CA: SAGE Publications.

Flyvbjerg, B. (1998). Empowering civil society: Habermas, Foucault and the question of conflict. In M. Douglass, and Freidmann, John (Ed.), Cities for citizens: Planning and the rise of civil society in a global age. NY: John Wiley \& Sons.

Flyvbjerg, B. (2001). Making social science matter: why social inquiry fails and how it can succeed again (S. Sampson, Trans.). Cambridge, UK: Cambridge University Press.

Foley, M. W., \& Edwards, B. (1998). Is it time to disinvest in social capital? Paper presented at the 94th Annual Meeting of the American Political Science Association. Retrieved.

Folke, C., Hahn, T., Olsson, P., \& Norberg, J. (2005). Adaptive governance of social-ecological systems. Annual Review of Environmental Resources, 30 , 441-473.

Follett, M. P. (1919). Community is a process. Philosophical Review, 28, 576-588.

Forester, J. (1999). The deliberative practitioner: encouraging participatory planning processes. Cambridge, MA: The MIT Press.

Forsyth, D. R. (2000). One hundred years of group research: introduction to the special issue. Group Dynamics: Theory, Research and Practice, 4(1), 3-6.

Foster-Fishman, P. G., Berkowitz, S. L., Lounsbury, D. W., Jacobson, S., \& Allen, N. A. (2001). Building collaborative capacity in community coalitions: a review and integrative framework. American Journal of Community Psychology, 29(2), 241-261.

Fredrickson, B. L. (2001). The role of positive emotions in positive psychology: the broaden-and-build theory of positive emotions. American Psychologist, 56(3), 218-226.

Fredrickson, B. L. (2003). The value of positive emotions. American Scientist, 91 , 
330-335.

Fredrickson, B. L. (2004). Positive emotions and upward spirals in organizational settings. In K. Cameron, J. E. Dutton \& R. E. Quinn (Eds.), Positive Organizational Scholarship (pp. 163-175). San Francisco, Ca: BerrettKoehler.

Freire, P. (2000). Pedagogy of the oppressed: 30th anniversary edition (M. B. Ramos, Trans.). NY: Continuum.

Frey, L. (1994). The naturalistic paradigm: studying small groups in the postmodern era. Small Group Research, 25(4), 551-577.

Friedmann, J. (1987). Planning in the public domain: from knowledge to action. Princeton, NJ: Princeton University Press.

Galbraith, M. W. (1998). Adult learning methods. Malabar, FL: Krieger Publishing Co.

Galinsky, A. D., \& Moskowitz, G. B. (2000). Perspective-taking: decreasing stereotype expression, stereotype accessibility, and in-group favoritism. Journal of Personality and Social Psychology, 78(4), 708-724.

Ganz, M. (2001). The power of story in social movements. Paper presented the Annual Meeting of the American Sociological Association.

Garson, G. D. (n.d.). Univariate GLM, ANOVA, and ANCOVA. Statnotes: Topics in multivariate analysis, 2005, from http://www2.chass.ncsu.edu/garson/pa765/anova.htm.

Garson, G. D. (n.d.). Factor Analysis. Statnotes: Topics in multivariate analysis Retrieved March 21, 2002, from http://www2.chass.ncsu.edu/garson/pa765/factor.htm.

Garson, G. D. (n.d.). Cluster Analysis. Statnotes: Topics in multivariate analysis Retrieved March 21, 2002, from http://www2.chass.ncsu.edu/garson/pa765/factor.htm.

Gastil, J. (1993). Identifying obstacles to small group democracy. Small Group Research, 24(1), 5-27.

Geren, P. R. (2001). Public discourse: creating the conditions for dialogue concerning the common good in a postmodern heterogeneous democracy. Studies in Philosophy and Education, 20(3), 191-199.

Gersick, C. J. G. (1988). Time and transition in work teams: toward a new model of group development. The Academy of Management Review, 31(1), 9-41.

Gersick, C. J. G. (1991). Revolutionary change theories: a multilevel exploration of the punctuated equilibrium paradigm. The Academy of Management Review, 16(1), 10-36.

Gibson, D., \& Mische, A. (1995). Internetwork encounters and the emergence of leadership. Unpublished manuscript, New York, NY: Columbia University Center for the Social Sciences.

Gilchrist, A. (2000). The well-connected community: networking to the 'edge of chaos'. Community Development Journal, 35(3), 264-275.

Girden, E. R. (1992). ANOVA repeated measures. Thousand Oaks, CA: Sage Publications. 
Glaser, J. (2004, December 8-11, 2004). Social movements as communities. Paper presented at the TASA 2004 Conference: Revisioning Institutions - Change in the 21st Century, La Trobe University, Beechworth Campus.

Gonzales, S., \& Healey, P. (2005). A sociological institutionalist approach to the study of innovation in governance capacity. Urban Studies, 42(11), 20552069.

Gove, W. (1994). Why we do what we do: a biopsychosocial theory of human motivation. Social Forces, 73(2), 363-394.

Granata, E. C. (2005). An assessment of search conferences: citizen participation and civic engagement in turbulent times. Unpublished Dissertation, University of Colorado at Denver.

Granovetter, M. (1983). The strength of weak ties: a network theory revisited. Sociological Theory, 1, 201-233.

Gray, B. (1985). Conditions facilitating interorganizational collaboration. Human Relations, 38(10), 911-936.

Gray, B. (2004). Strong opposition: frame-based resistance to collaboration. Journal of Community and Applied Social Psychology, 14, 166-176.

Gray, B., \& Wood, D. J. (1991). Collaborative alliances: moving from practice to theory. The Journal of Applied Behavioral Science, 27(1), 3-22.

Greene, J. C. (2005). The generative potential of mixed methods inquiry. International Journal of Research and Method in Education, 28(2), 207-211.

Greenwood, D., \& Levin, M. (1998). Introduction to action research: social research for social change. Thousand Oaks, CA: SAGE Publications.

Griffin, T., \& Purser, R. (In Press). Large group interventions: whole systems approaches to organizational change. In T. Cummings (Ed.), Handbook of Organization Development. Thousand Oaks, CA: Sage.

Grubbs, J. W. (2002). Participation and change: using large group intervention methods to inform reflective practice in a community of public organizations. Public Organization Review: A Global Journal, 2, 285-303.

Grube, J., Mayton, D., \& Ball-Rokeach, S. (1994). Inducing change in values, attitudes, and behaviors: belief system theory and the method of value selfconfrontation. Journal of Social Issues, 50(4), 153(121).

Guagnano, G., Stern, P., \& Dietz, T. (1995). Influences on attitude-behavior relationships: a natural experiment with curbside recycling. Environment and Behavior, 27(5), 699-718.

Guba, E., and Lincoln, Yvonna. (2001). Guidelines and checklist for constructivist (a.k.a Fourth Generation) evaluation. Unpublished manuscript.

Guba, E., \& Lincoln, Y. (1994). Competing paradigms in qualitative research. In N. Denzin \& Y. Guba (Eds.), Handbook of Qualitative Research (pp. 105-117): Sage.

Gulati, R. (1995). Does familiarity breed trust? The implications of repeated ties for contractual choice in alliances. Academy of Management Journal, 38(1), 85112.

Gunderson, A. (1995). The environmental promise of democratic deliberation. 
Madison, WI: The University of Wisconsin Press.

Gustavsen, B. (2001). Theory and practice: the mediating discourse. In P. Reason \& H. Bradbury (Eds.), Handbook of action research: Participative inquiry and practice (pp. 17-26). Thousand Oaks, CA: SAGE Publications.

Hahn, T., Olsson, P., Folke, C., \& Johnsson, K. (2006). Trust-building, knowledge generation and organizational innovations: the role of a bridging organization for adaptive co-management of a wetland landscape around Kristianstad, Sweden. Human Ecology, 34, 573-592.

Hammer, J., \& Margheim, J. (2006). Supporting sustainable regional food systems: a roadmap to the content, process, and uses of regional food system assessments. Portland, OR: Portland State University, Community Food Matters Initiative of the School of Urban Studies \& Planning and School of Community Health.

Handley, K., Sturdy, A., Fincham, R., \& Clark, T. (2006). Within and beyond communities of practice: making sense of learning through participation, identity and practice. Journal of Management Studies, 43(3), 641-653.

Hardy, C., \& Phillips, N. (1998). Strategies of engagement: lessons from the critical examination of collaboration and conflict in an interorganizational domain. Organization Science, 9(2), 217-230.

Hardy, C., Phillips, N., \& Lawrence, T. B. (2003). Resources, knowledge and influence: the organizational effects of interorganizational collaboration. Journal of Management Studies, 40(2), 321-347.

Hartley, T. W. (1998). Participant competencies in deliberative discourse: cases of collaborative decision-making in the Superfund program. Unpublished Dissertation, University of Michigan, Ann Arbor.

Healey, P. (1997). Collaborative planning: shaping places in fragmented societies. Vancouver, BC: UBC Press.

Healey, P. (2003). Collaborative planning in perspective. Planning Theory 2(2), 101123.

Healy, M., \& Perry, C. (2000). Comprehensive criteria to judge validity and reliability of qualitative research within the realism paradigm. Qualitative Market Research: An International Journal, 3(3), 118-126.

Heany, T. (1996). Adult education for social change: from center stage to the wings and back again (No. ERIC Document Reproduction Service No. ED 396 190). Washington, DC: Office of Educational Research and Improvement.

Hemmati, M. (2002). Multi-stakeholder processes for governance and sustainability: beyond deadlock and conflict. Sterling, VA: Earthscan Publications Ltd.

Hibbert, P., \& Huxham, C. (2005). A little about the mystery: process learning as collaboration evolves. European Management Review, 2, 59-69.

Hill, J. (2000). A rationale for the integration of spirituality into community psychology. Journal of Community Psychology, 28(2), 139-149. 
Hill, L. H. (2001). The brain and consciousness: sources of information for understanding adult learning. New Directions for Adult and Continuing Education, 89, 73-81.

Himmelman, A. T. (1996). On the theory and practice of transformational collaboration: from social service to social justice. In C. Huxham (Ed.), Creating Collaborative Advantage (pp. 19-43). London: Sage Publications.

Himmelman, A. T. (2001). On coalitions and the transformation of power relations: collaborative betterment and collaborative empowerment. American Journal of Community Psychology, 29(2), 277-284.

Hochachka, G. (2005). Integrating interiority in community development. World Futures, 61, 110-126.

Hoggett, P., \& Miller, C. (2000). Working with emotions in community organizations. Community Development Journal, 35(4), 352-364.

Holman, P., Devane, T., \& Cady, S. (2007). The change handbook: the definitive resource on today's best methods for engaging whole systems (Second ed.). San Francisco, CA: Berrett-Koehler.

Hood, J. N., Logsdon, J. M., \& Thompson, J. K. (1993). Collaboration for social problem-solving: a process model. Business Society, 32(1), 1-17.

Hooghe, M., \& Stolle, D. (2003). Generating social capital. New York, NY: Palgrave Macmillan.

Horn Jr., R. A. (2005). Post-Formal conversations. In B. Banathy \& P. M. Jenlink (Eds.), Dialogue as a means of collective communication (pp. 291-323). New York, NY: Kluwer Academic/Plenum Publishers.

Howe, K. R. (1988). Against the quantitative-qualitative incompatibility thesis. Educational Researcher, 17(8), 10-16.

Hugo, J. M. (2002). Learning community history. New Directions for Adult and Continuing Education, 95, 5-25.

Hustedde, R. J., \& Ganowicz, J. (2002). The basics: what's essential about theory for community development practice? Journal of the Community Development Society, 33(1), 1-18.

Huxham, C. (1993). Pursuing collaborative advantage. Journal of the Operational Research Society, 44(6), 599-611.

Huxham, C. (Ed.). (1996). Creating collaborative advantage. London: Sage Publications.

Huxham, C. (2003). Theorizing collaboration practice. Public Management Review, $5(3), 401-423$.

Huxham, C., \& Hibbert, P. (2004). Collaborating to know? Interorganizational engagement and learning. AIM Research Working Paper Series, 2-35.

Huxham, C., \& Vangen, S. (2000). Ambiguity, complexity and dynamics in the membership of collaboration. Human Relations, 53(6), 771-806.

Huxham, C., \& Vangen, S. (2000). Leadership in the shaping and implementation of collaboration agendas: how things happen in a (not quite) joined-up world. Academy of Management Journal, 43(6), 1159-1175. 
Huxham, C., \& Vangen, S. (2004). Realizing the advantage or succumbing to inertia? Organizational Dynamics, 33(2), 190-201.

Imel, S. (1996). Summing up: themes and issues related to learning in groups. New Directions for Adult and Continuing Education, 71, 91-96.

Imel, S. (1998). Transformative learning in adulthood. Retrieved. from.

Imel, S., \& Stein, D. (2003). Creating self-awareness of learning that occurs in community. Paper presented at the Midwest Research to Practice Conference in Adult, Continuing, and Community Education. Retrieved.

Imel, S., \& Tisdell, E. J. (1996). The relationship between theories about groups and adult learning groups. New Directions for Adult and Continuing Education, $71,15-24$.

Imel, S., \& Zengler, C. J. (2002). For the common good: learning through interagency collaboration. New Directions for Adult and Continuing Education, 95, 41-49.

Imperial, M. T. (2005). Using collaboration as a governance strategy: lessons from six watershed management programs. Administration and Society, 37(3), 281-320.

Innes, J. E. (1992). Group processes and the social construction of growth management: Florida, Vermont, and New Jersey. Journal of the American Planning Association, 58(4), 440-454.

Innes, J. E. (1996). Planning through consensus building: a new view of the comprehensive planning ideal. Journal of the American Planning Association, 62(4), 460-472.

Innes, J. E. (1999). Evaluating consensus building. In L. Susskind, S. McKearnan \& J. Thomas-Larmer (Eds.), The consensus handbook: A comprehensive guide to reaching agreement (pp. 631-675). Thousand Oaks: Sage Publications, Inc.

Innes, J. E. (2004). Consensus building: clarifications for the critics. Planning Theory, 3(No. 1), 5-20.

Innes, J. E., \& Booher, D. E. (1999). Consensus building and complex adaptive systems a framework for evaluating collaborative planning. Journal of the American Planning Association, 65(4), 412-423.

Innes, J. E., \& Booher, D. E. (1999). Consensus building as role playing and bricolage: toward a theory of collaborative planning. Journal of the American Planning Association, 65(1), 9-25.

Innes, J. E., \& Booher, D. E. (2002). The impact of collaborative planning on governance capacity. Paper presented at the Annual Conference of the Association of Collegiate Schools of Planning, Baltimore, MD.

Innes, J. E., \& Booher, D. E. (2004). Reframing public participation: strategies for the 21st century. Planning Theory and Practice, 5(4), 419-436.

Isaacs, W. (1999). Dialogue and the art of thinking together: a pioneering approach to communicating in business and in life. New York, NY: Currency. 
Israel, B. A., Checkoway, B., Schulz, A., \& Zimmerman, M. (1994). Health education and community empowerment: conceptualizing and measuring perceptions of individual, organizational, and community control. Health Education Quarterly, 21(2), 149-170.

Jamal, T. B., Stein, S. M., \& Harper, T. L. (2002). Beyond labels: pragmatic planning in multistakeholder tourism-environmental conflicts. Journal of Planning Education and Research, 22(2), 164-177.

Jansen, K. J. (1996). Characteristic level of change: an inherent constraint to organizational action. The International Journal of Organizational Analysis, 4(3), 285-298.

Jenkins-Smith, H. C., \& Sabatier, P. A. (1993). Methodological appendix: measuring longitudinal change in elite beliefs using content analysis of public documents. In P. A. Sabatier \& H. C. Jenkins-Smith (Eds.), Policy change and learning: an advocacy coalition approach. Boulder, $\mathrm{CO}$ : Westview.

Johnson-Bailey, J., \& Cervero, R. M. (1997). Negotiating power dynamics in workshops. New Directions for Adult and Continuing Education, 76, 41-50.

Jorgensen, K. M. (2004). Creating value-based collaboration: life forms and power in a change project. $M @ n @ g e m e n t, 7(3), 85-107$.

Kaplan, A. (2000). Capacity building: shifting the paradigms of practice. Development in Practice, 10(3/4), 517-526.

Kasl, E., \& Yorks, L. (2002). An extended epistemology for transformative learning theory and its application through collaborative inquiry. Teachers College Record Online, 1-17.

Kearney, A., \& Kaplan, S. (1997). Toward a methodology for the measurement of knowledge structures of ordinary people: The conceptual content cognitive map (3CM). Environment and Behavior, 29(5), 579(539).

Keast, R., Mandell, M. P., Brown, K., \& Woolcock, G. (2004). Network structures: working differently and changing expectations. Public Administration Review, 64(3), 363-371.

Kemmis, D. (1990). Community and the politics of place. Oklahoma City: University of Oklahoma Press.

Kemp, R., Parto, S., \& Gibson, R. B. (2005). Governance for sustainable development: moving from theory to practice. International Journal of Sustainable Development, 8(1/2), 12-30.

Kempton, W., Boster, J. S., \& Hartley, J. A. (1995). Environmental values in American culture. Cambridge, MA: The MIT Press.

Keppel, G. (1991). Design and analysis: a researcher's handbook (Third ed.). Upper Saddle, NJ: Prentice Hall.

Kilpatrick, S., Barrett, M., \& Jones, T. (2003). Defining learning communities (No. Discussion Paper D1/2003). Launceston, Tasmania: Australia: Centre for Research and Learning, University of Tasmania.

Kilpatrick, S., Bell, R., \& Falk, I. (1999). The role of group learning in building social capital. Journal of Vocational Education and Training, 51(1), 129144. 
Kloppenburg, J. J., Lezberg, S., DeMaster, K., Stevenson, G. W., \& Hendrickson, J. (2000). Tasting food, tasting sustainability: defining the attributes of an alternative food system with competent, ordinary people. Human Organization, 59(2), 177-185.

Knight, L., \& Pye, A. (2005). Network learning: an empirically derived model of learning by groups of organizations. Human Relations, 58(3), 369-392.

Kretzmann, J. P., \& McKnight, J. L. (1993). Building communities from the inside out: a path toward finding and mobilizing a community's assets. Chicago, IL: ACTA Publications.

Krishna, A. (2002). Active social capital: tracing the roots of democracy and development: Columbia University Press.

Krosnick, J. A. (1991). The stability of political preferences: comparisons of symbolic and nonsymbolic attitudes. American Journal of Political Science, 35(2), 548-575.

Kumar, A., \& Paddison, R. (2000). Trust and collaborative planning theory: the case of the Scottish planning system. International Planning Studies, 5(2), 205223.

Lange, E. A. (2004). Transformative and restorative learning: A vital dialectic for sustainable societies. Adult Education Quarterly, 54(2), 121-139.

Langhelle, O. (2000). Why ecological modernization and sustainable development should not be conflated. Journal of Environmental Policy and Planning, 2(4), 303-322.

Lasker, R. D., \& Weiss, E. S. (2003). Broadening participation in community problem solving: a multidisciplinary model to support collaborative practice and research. Journal of Urban Health, 80(1), 14-47.

Lather, P. (1986). Research as praxis. Harvard Educational Review, 56(3), 257-277.

Lave, J., \& Wenger, E. (1991). Situated learning: legitimate peripheral participation. Cambridge: University of Cambridge Press.

Lawrence, T. B., Hardy, C., \& Phillips, N. (2002). Institutional effects of interorganizational collaboration: the emergence of proto-institutions. Academy of Management Journal, 45(1), 281-290.

Lebel, L., Anderies, J. M., Campbell, B., Folke, C., Hatfield-Dodds, S., Hughes, T. P., et al. (2006). Governance and the capacity to manage resilience in regional social-ecological systems. Ecology and Society, 11(1), art19.

LeCompte, M., and Goetz, Judith. (1982). Problems of reliability and validity in ethnographic research. Review of Education Research, 52(1), 31-60.

Legler, R., \& Reischl, T. (2003). The relationship of key factors in the process of collaboration: a study of school-to-work coalitions. The Journal of Applied Behavioral Science, 39(1), 53-72.

Leith, M. (1996). Organizational change and large group interventions. Career Development International, 1(4), 19-23.

Lent, R. M., McCormick, M. T., \& Pearce, D. S. (2005). Combining Future Search and Open Space to address special situations. The Journal of Applied Behavioral Science, 41(1), 61-69. 
Lerner, S. (2006). Working Paper No. 3: Governance for sustainability: dynamics of collaborative arrangements. Waterloo, Ontario: University of Waterloo, Department of Environment and Resource Studies.

Lewicki, R. J., Litterer, J. A., Minton, J. W., \& Saunders, D. M. (1994). Negotiation. Burr Ridge, IL: Irwin.

Light, I. (2004). Social capital's unique accessibility. Journal of the American Planning Association, 70(2), 145-151.

Lin, N. (1999). Building a network theory of social capital. Connections, 22(1), 2851.

Lin, N. (2001). Social capital: a theory of social structure and action. New York: NY: Cambridge University Press.

Lincoln, Y. S., \& Guba, E. (1985). Naturalistic inquiry. Beverly Hills, CA: Sage Publications.

Lord, K. R. (1995). Combined influence hypothesis: Central and peripheral. Journal of Advertising, 1-13.

Lorr, M. (1983). Cluster analysis for social scientists. San Francisco, CA: JosseyBass.

Lotia, N. (2004). Power dynamics and learning in collaborations. Journal of the Australian and New Zealand Academy of Management, 10(2), 56-68.

Ludema, J. D., Cooperrider, D. L., \& Barrett, F. J. (2001). Appreciative inquiry: the power of the unconditional positive question. In P. Reason \& $\mathrm{H}$. Bradbury (Eds.), Handbook of action research: Participative inquiry and practice (pp. 189-199). Thousand Oaks, CA: SAGE Publications.

Ludema, J. D., Wilmot, T. B., \& Srivastva, S. (1997). Organizational hope: reaffirming the constructive task of social and organizational inquiry. Human Relations, 50(8), 1015-1052.

Maarleveld, M., \& Dangegnon, C. (1999). Managing natural resources: a social learning perspective. Agriculture and Human Values, 16, 267-280.

Mandell, M. P. (1999). The impact of collaborative efforts: changing the face of public policy through networks and network structures. Policy Studies Review, 16(1), 4-17.

Mandell, M. P. (1999). Community collaborations: working through network structures. Policy Studies Review, 16(1), 42-64.

Manning, M. R., \& Binzagr, G. F. (1996). Methods, values, and assumptions underlying large group interventions intended to change whole systems. The International Journal of Organizational Analysis, 4(3), 268-284.

Margerum, R. (2002). Collaborative planning: building consensus and building a distinct model for practice. Journal of Planning Education and Research, 21(3), 237-253.

Margerum, R. D. (1999). Getting past yes: from capital creation to action. Journal of the American Planning Association, 65(2), 181-191.

Margerum, R. D. (2002). Evaluating collaborative planning: implications from an empirical analysis of growth management. Journal of the American Planning Association, 68(2), 179-192. 
Marsick, V., Bitterman, J., \& van der Veen, R. (2000). From the learning organization to learning communities toward a learning society (No. 382).

Marsick, V., \& Kasl, E. (1997). Factors that affect the epistemology of group learning: a research-based analysis. Paper presented at the Adult Education Research Conference Stillwater, OK.

Marsick, V., \& O'Neil, J. (1999). The many faces of action learning. Management Learning, 30(2), 159-176.

Marsick, V., \& Watkins, K. (2001). Informal and incidental learning. New Directions for Adult and Continuing Education, 89, 25-34.

Martin, A. W. (2000). Search conference methodology and the politics of difference. Columbia University Teachers College, New York, NY.

Martin, A. W. (2001). Large-group processes as action research. In P. Reason \& H. Bradbury (Eds.), Handbook of action research: Participative inquiry and practice (pp. 200-208). Thousand Oaks, CA: SAGE Publications.

Mathews, D. (1994). Politics for people: finding a responsible voice (Second ed.). Urbana, IL: University of Illinois Press.

Mattessich, P. W., \& Monsey, B. R. (1992). Collaboration: what makes it work - A review of research literature on factors influencing successful collaboration. St. Paul: MN: Amherst H. Wilder Foundation.

Matton, K. I. (2000). Making a difference: the social ecology of social transformation. American Journal of Community Psychology, 28(1), 25-57.

McAllister, D. J. (1995). Affect - and cognition-based trust as foundations for interpersonal cooperation in organizations. Academy of Management Journal, 38(1), 24-59.

McCann, J. E. (1983). Design guidelines for social problem-solving interventions. The Journal of Applied Behavioral Science, 19(2), 177-192.

McCullum, C., Pelletier, D., Barr, D., \& Wilkins, J. (2002). Use of a participatory planning process as a way to build community food security. Journal of the American Dietetic Association, 102(7), 962-967.

McCullum, C., Pelletier, D., Barr, D., \& Wilkins, J. (2003). Agenda setting within a community-based food security planning process: the influence of power. Journal of Nutrition Education and Behavior, 35(4), 189-197.

McMillan, D. W. (1996). Sense of community. Journal of Community Psychology, 24(4), 315-325.

McMillan, D. W., \& Chavis, D. M. (1986). Sense of community: a definition and theory. Journal of Community Psychology, 14(1), 6-23.

Merriam, S., \& Caffarella, R. (1999). Learning in adulthood. San Francisco, CA: Jossey-Bass.

Mezirow, J. (Ed.). (1990). Fostering critical reflection in adulthood: a guide to transformative and emancipatory learning. San Francisco, CA: Jossey-Bass.

Mikheyev, A. (2005). Multi-stakeholder partnerships: definition, principles, typology, and partnering process. Moscow, Russia: Internet Politics Center, Moscow State Institute of International Relations. 
Mingers, J. (2004). Can social systems be autopoietic? Bhaskar's and Giddens' social theories. Journal for the Theory of Social Behaviour, 34(4), 405-427.

Mohai, P. (1997). Men, women, and the environment: An examination of the gender gap in environmental concern and action. In C. E. Sachs (Ed.), Women working in the environment (pp. 215-240). Washington, DC: Taylor and Francis.

Moore, A. B., \& Brooks, R. (2000). Learning communities and community development: describing the process. International Journal of Adult and Vocational Learning, 1, 1-15.

Moran-Ellis, J., Alexander, V. D., Cronin, A., Dickinson, M., Fielding, J., Sleney, J., et al. (2006). Triangulation and integration: processes, claims and implications. Qualitative Research, 6(1), 45-59.

Moreland, R. L., Tom. (1997). Lifelong learning and community development. International Journal of Lifelong Education, 16(3), 201-216.

Morrison, K. (2005). Structuration theory, habitus and complexity theory: elective affinities or old wine in new bottles? British Journal of Sociology of Education, 26(3), 311-326.

Mundy, D. (2002). Solution corner: A question of response rate. Science Editor, 25(1), 25-26.

Nagda, B. R. A. (2006). Breaking barriers, crossing borders, building bridges: communication processes in intergroup dialogues. Journal of Social Issues, 62(3), 553-576.

Negra, C., \& Manning, R. (1997). Incorporating environmental behavior, ethics, and values into nonformal environmental education programs. The Journal of Environmental Education, 28(2), 10-21.

Newman, L., \& Dale, A. (2004). Network structure, diversity, and proactive resilience building: a response to Tompkins and Adger. Ecology and Society, 10(1), $\mathrm{r} 2$.

Nexus For Change. (n.d.). A bit more about the conference. from http://www.nexusforchange.org/index.php3?object $\mathrm{id}=5488 \mathrm{a} 104 \mathrm{~b} 4 \mathrm{e} 1 \mathrm{fa} 6461$ 03d99b63add3ff.

Nielsen-Pincus, M. (2002). Social capital and sustainability: a qualitative study of community leaders in the conservation economy. Portland, OR: Ecotrust and Antioch University Seattle.

O'Hara, M., \& Wood, J. K. (2005). Building a conscious group through deep dialogue. In B. Banathy \& P. M. Jenlink (Eds.), Dialogue as a means of collective communication (pp. 105-136). New York, NY: Kluwer Academic/Plenum Publishers.

O'Sullivan, E. (1999). Transformative learning: educational vision for the 21st century. NY: Zed Books.

O'Toole, L. (1997). Treating networks seriously: practical and research-based agendas in public administration. Public Administration Review, 57(1), 4552. 
O*NET Resource Center. (2002). Occupational Information Network (O*NET) OnLine: scales, ratings, and standardized scores. From http://online.onetcenter.org/help/online/scales.

Oels, A. (2002). Investigating the emotional roller-coaster ride: a case study-based assessment of the Future Search Conference Design. Systems Research and Behavioral Science, 19, 347-355.

Olsson, P., Gunderson, L. H., Carpetner, S. R., Ryan, P., Lebel, L., Folke, C., et al. (2006). Shooting the rapids: navigating transitions to adaptive governance of social-ecological systems. Ecology and Society, 11(1), art18.

Orr, D. (1992). Ecological literacy: education and the transition to a postmodern world. Albany, NY: SUNY Press.

Orr, D. (2002). Four challenges of sustainability. Conservation Biology, 16(6), 1457 1460.

Osborn, R., \& Hagedoorn, J. (1997). The institutionalization and evolutionary dynamics of interorganizational alliances and networks. Academy of Management Journal, 40, 261-278.

Ospina, S., \& Saz-Carranza, A. (2005). Paradox and collaboration in coalition work. Paper presented at the 2005 Annual Meeting of the Academy of Management. Retrieved.

Ozawa, C. (1991). Recasting science: consensual procedures in public policy. Boulder, CO: Westview Press.

Pahl-Wostl, C. (2002). Towards sustainability in the water sector: the importance of human actors and processes of social learning. Aquatic Sciences, 64, 394411.

Pahl-Wostl, C., \& Hare, M. (2004). Processes of social learning in integrated resources management. Journal of Community and Applied Social Psychology, 14, 193-206.

Paquet, G. (2004). The governance of sustainability: a social learning approach. Paper presented at the First National Capital Colloquium on the Governance of Sustainable Development. Retrieved. from http://invenire.ca/Res papers/Governance of sustainability.pdf.

Parker, B., \& Selsky, J. W. (2004). Interface dynamics in cause-based partnerships: an exploration of emergent culture. Nonprofit and Voluntary Sector Quarterly, 33(3), 458-488.

Parson, E. A., \& Clark, W. C. (1995). Sustainable development as social learning: theoretical perspectives and practical challenges for the design of a research program. In L. H. Gunderson, C. S. Holling \& S. S. Light (Eds.), Barriers and bridges to the renewal of ecosystems and institutions (pp. 429-460). New York, NY: Columbia University Press.

Pasquero, J. (1991). Supraorganizational collaboration: the Canadian environmental experiment. The Journal of Applied Behavioral Science, 27(1), 38-64.

Payne, S., L., \& Calton, J., M. (2004). Exploring research potentials and applications for multi-stakeholder learning dialogues. Journal of Business Ethics, 55, 7178 . 
Payne, S., L., \& Calton, J. M. (2002 ). Toward a managerial practice of stakeholder engagement: developing multistakeholder learning dialogues. Journal of Corporate Citizenship, 6, 37-52.

Pelletier, D., Kraak, V., McCullum, C., \& Uusitalo, U. (2000). Values, public policy, and community food security. Agriculture and Human Values, 17, 75-93.

Pelletier, D., Kraak, V., McCullum, C., Uusitalo, U., \& Rich, R. (1999). The shaping of collective values through deliberative democracy: an empirical study from New York's North Country. Policy Sciences, 32, 103-131.

Pelletier, D., Kraak, V., McCullum, C., Uusitalo, U., \& Rich, R. (1999). Community food security: salience and participation at community level. Agriculture and Human Values, 16, 401-419.

Pelletier, D., McCullum, C., Kraak, V., \& Asher, K. (2003). Participation, power, and beliefs shape local food and nutrition policy. The Journal of Nutrition, $133,301 \mathrm{~S}-304 \mathrm{~S}$.

Percy, R. (2005). The contribution of transformative learning theory to the practice of participatory research and extension: Theoretical reflections. Agriculture and Human Values, 22(2), 127-136.

Perkins, D. D., Bess, K., Cooper, D. G., Jones, D. L., Armstead, T., \& Speer, P. W. (2007). Community organizational learning: case studies illustrating a threedimensional model of levels and orders of change. Journal of Community Psychology, 35(3), 303-328.

Phillips, D., \& Soltis, J. (2003). Perspectives on learning. New York, NY: Teachers College Press.

Phillips, M. E., \& Huzzard, T. (2007). Developmental magic? Two takes on a dialogue conference. Journal of Organizational Change Management, 20(1), 8-25.

Phillips, N., Lawrence, T. B., \& Hardy, C. (2000). Inter-organizational collaboration and the dynamics of institutional fields. Journal of Management Studies, 37(1), 23-43.

Pike, W., Yarnal, B., MacEacheren, A. M., Gahegan, M., \& Yu, C. (2005). Retooling collaboration: a vision for environmental change research. Environment, 8-21.

Pioneers of Change Associates. (2006). Mapping dialogue: a research project profiling tools and processes for social change. Johannesburg, South Africa: Commissioned by The German Technical Co-Operation Project: Support to the HIV/AIDS Programme of the Nelson Mandela Foundation.

Polanyi, M. (2001). Toward common ground and action on repetitive strain injuries. The Journal of Applied Behavioral Science, 37(4), 465-487.

Polanyi, M. (2002). Communicative action in practice: Future Search and the pursuit of an open, critical and non-coercive large-group process. Systems Research and Behavioral Science, 19(4), 357-366.

Polletta, F., \& Jasper, J. M. (2001). Collective identity and social movements. Annual Review of Sociology, 27, 283-305. 
Poncelet, E. C. (1998). A kiss here and a kiss there: conflict and non-confrontation in a multi-stakeholder environmental partnership in Belgium. Paper presented at the Crossing Boundaries, Seventh Annual Conference of the International Association for the Study of Common Property. Retrieved.

Poncelet, E. C. (1999). In search of the "win-win": possibilities and limitations of multi-stakeholder environmental partnerships. Paper presented at the 1999 Greening of Industry Network Conference.

Poncelet, E. C. (2001). Personal transformation in multistakeholder environmental partnerships. Policy Sciences, 34, 273-301.

Poncelet, E. C. (2001). A kiss here and a kiss there: conflict and collaboration in environmental partnerships. Environmental Management, 27(1), 13-25.

Portes, A. (1998). Social capital: its origins and applications in modern sociology. Annual Review of Sociology, 24, 1-24.

Portland Metro Health and Food Systems Task Force. (2006). Food security and health: report of findings. Corvallis, OR: Oregon State University Extension Service.

Potapchuk, W. R. (1998). Collaborative approach to nutrition education in schools and communities: Exploring the lessons. Journal of Nutrition Education, 30(5), 332-339.

Powell, W. W., Koput, K. W., White, D. R., \& Owen-Smith, J. (2005). Network dynamics and field evolution: the growth of interorganizational collaboration in the life sciences. American Journal of Sociology, 110(4), 1132-1205.

Pratkanis, A., \& Turner, M. (1996). Persuasion and democracy: strategies for increasing deliberative participation and enacting social change. Journal of Social Issues, 52(1), 187-205.

Pruitt, B., Waddell, S., Kaeufer, K., \& Parrot, K. (2005). Dialogic approaches to global challenges: moving from "dialogue fatigue" to dialogic change processes. New York, NY: Generative Dialogue Project.

Purpel, D. (1989). The moral and spiritual crisis in education: a curriculum for justice and compassion in education. New York, NY: Bergin \& Garvey Publishers, Inc.

Purpel, D., \& Shapiro, S. (1998). Beyond liberation and excellence: a discourse for education as transformation. In H. S. Shapiro, \& David Purpel (Ed.), Critical social issues in American education (pp. 373-409). Mahwah, NJ: Lawrence Erlbaum Associates.

Putnam, L., \& Stohl, C. (1990). Bona fide groups: a reconceptualization of groups in context. Communication Studies, 41(3), 248-265.

Putnam, R. (1993). Making democracy work: civic traditions in modern Italy. Princeton, NY: Princeton University Press.

Reason, P. (2002). Justice, sustainability, and participation. Concepts and Transformations, 7(1), 7-29.

Reason, P. (2004). Action research and the single case: a response to Bjorn Gustavsen. Concepts and Transformations, 8(3), 281-294. 
Rice, S., \& Burbules, N. (1992). Communicative virtues and educational relations. In H. Alexander (Ed.), Philosophy of education (pp. 34-44). Urbana, IL: Philosophy of Education Society.

Riege, A. M. (2003). Validity and reliability tests in case study research: a literature review with "hands-on" applications for each research phase. Qualitative Market Research: An International Journal, 6(2), 75-86.

Rittel, H., W. J., \& Webber, M. (1973). Dilemmas in a general theory of planning. Policy Sciences, 4, 155-169.

Rohe, W. M. (2004). Building social capital through community development. Journal of the American Planning Association, 70(2), 158-164.

Roling, N., \& Woodhill, J. (Eds.). (2002). Guidance for initiating national and basin level dialogues: dialogue working paper 5. Colombo, Sri Lanka: Dialogue Secretariat, International Water Management Institute.

Roman, J. (2005). A study of organizational dialogue: facing the truth, gaining inspiration and creating understanding of the function of an organization. Helsinki University of Technology, Helsinki, Finland.

Rose, A. (1996). Group learning in adult education: its historical roots. New Directions for Adult and Continuing Education, 71, 3-13.

Rosenthal, B. B. (1998). Collaboration for the nutrition field: synthesis of selected literature. Journal of Nutrition Education, 30(5), 246-267.

Rossing, B. E. (1991). Patterns of informal incidental learning: insights from community action. International Journal of Lifelong Education, 10(1), 45-60.

Roussos, S. T., \& Fawcett, S. B. (2000). A review of collaborative partnerships as a strategy for improving community health. Annual Review of Public Health, $21,369-402$.

Sachs, C. E. (1996). Gendered fields: rural women, agriculture, and environment. Boulder, CO: Westview Press.

Salomon, G., \& Perkins, D. N. (1998). Individual and social aspects of learning. Review of Research in Education, 23, 1-24.

Sandercock, L. (2003). Out of the closet: the importance of stories and storytelling in planning practice. Planning Theory and Practice, 4(1), 11-28.

Sandercock, L. (2004). Longer view: towards a planning imagination for the 21st Century. Journal of the American Planning Association, 70(2), 133-141.

Schafft, K. A., \& Greenwood, D. J. (2003). Promises and dilemmas of participation: action research, search conference methodology, and community development. Journal of the Community Development Society, 34(1), 18-35.

Schein, E. H. (1993). On dialogue, culture, and organizational learning. Organizational Dynamics, 22, 40-51.

Schemel, B. (1996). The Inquiry: fostering adult education for individual and social change. International Journal of Lifelong Education, 15(3), 177-191.

Schindler-Rainman, E., \& Lippitt, R. (1992). Building collaborative communities. In M. R. Weisbord (Ed.), Discovering Common Ground. San Francisco, CA: Berrett-Koehler. 
Schommer. (1998). The role of adults' beliefs about knowledge in school, work, and everyday life. In M. C. Smith \& T. Pourchot (Eds.), Adult learning and development: Perspectives from educational psychology (pp. 89-106). Mahway: NJ: Lawrence Erlbaum Associates.

Schon, D. (1983). The reflective practitioner: how professionals think in action. USA: Basic Books, Inc.

Schuller, T., \& Field, J. (1998). Social capital, human capital and the learning society. International Journal of Lifelong Education, 17(4), 226-235.

Schusler, T. M., Decker, D. J., \& Pfeffer, M. J. (2003). Social learning for collaborative natural resource management. Society and Natural Resources, 15, 309-326.

Schutt, R. (1999). Investigating the social world: the process and practice of research. Thousand Oaks, CA: Pine Forge Press.

Selin, S., \& Chevez, D. (1995). Developing a collaborative model for environmental planning and management. Environmental Management, 19(2), 189-195.

Selin, S., Schuett, M. A., \& Carr, D. (2000). Modeling stakeholder perceptions of collaborative initiative effectiveness. Society and Natural Resources, 13, 735-745.

Selsky, J. W. (1998). Developmental dynamics in nonprofit-sector federations. Voluntas: International Journal of Voluntary and Nonprofit Organizations, 9(3), 283-303.

Selsky, J. W., \& Barton, J. (2000). The third track of the Open-Systems-Thinking School: an application of domain theory to New Zealand ports. Systemic Practice and Action Research, 13(3), 257-277.

Selsky, J. W., \& Parker, B. (2005). Cross-sector partnerships to address social issues: Challenges to theory and practice. Journal of Management 31(6), 849-873.

Senge, P., Kleiner, A., Roberts, C., Ross, R., \& Smith, B. (1994). The fifth discipline fieldbook: strategies and tools for building a learning organization. New York, NY: Currency.

Senge, P., \& Scharmer, O. (2001). Community action research: learning as a community of practitioners, consultants and researchers. In P. Reason \& H. Bradbury (Eds.), Handbook of action research: participative inquiry and practice (pp. 238-249). Thousand Oaks, CA: SAGE Publications.

Sheskin, D. (1997). Handbook of parametric and nonparametric statistical procedures. Boca Raton, FL: CRC Press.

Simonin, B. L. (1997). The importance of collaborative know-how: an empirical test of the learning organization. Academy of Management Journal, 40(5), 1150 1174.

Sink, D. (1996). Five obstacles to community-based collaboration and some thoughts on overcoming them. In C. Huxham (Ed.), Creating Collaborative Advantage (pp. 101-109). London: Sage Publications.

Sink, D. W. (1991). Transorganizational development in urban policy coalitions. Human Relations, 44(11), 1179-1195. 
Slocum, R. (2006). Anti-racist practice and the work of community food organizations. Antipode, 38(2), 327-349.

Slotte, S. (2004). Rethinking dialogue: philosophy and systems intelligence. In R. P. Hamalainen \& E. Saarinen (Eds.), Systems intelligence - discovering a hidden competence in human action and organizational life (pp. 1-23). Helsinki, Finland: University of Technology: Systems Analysis Laboratory Research Reports A88.

Smith, G. A., \& Williams, D. R. (Eds.). (1998). Ecological education in action: on weaving education, culture, and the environment. Albany, NY: SUNY Press.

Snow, D. A., Rochford Jr., E. B., Worden, S. K., \& Benford, R. D. (1986). Frame alignment processes, micromobilization, and movement participation. American Sociological Review, 51(4), 464-481.

Stake, R. E. (1995). The art of case study research. Thousand Oaks, CA: SAGE Publications.

StatSoft, I. (2002). Electronic statistics textbook. from http://www.statsoft.com/textbook/stcluan.html.

Steins, N. A., \& Edwards, V. M. (1999). Platforms for collective action in multipleuse common-pool resources. Agriculture and Human Values, 16, 241-255.

Stern, P. (2000). New environmental theories: toward a coherent theory of environmentally significant behavior. Journal of Social Issues, 56(3), 407424.

Stern, P., Dietz, T., \& Guagnano, G. (1998). A brief inventory of values. Educational and Psychological Measurement, 58(6), 984.

Stevens, J. (1996). Applied multivariate statistics for the social sciences (Third ed.). Mahwah, NJ: Lawrence Erlbaum Associates.

Stockburger, D. W. (1998). Cluster analysis. In Multivariate statistics: concepts, models, and applications. Springfield, MO: Missouri State University.

Stringer, L. C., Dougill, A. J., Fraser, E., Hubacek, K., Prell, C., \& Reed, M. S. (2006). Unpacking "participation" in the adaptive management of socialecological systems: a critical review. Ecology and Society, 11(2), art39.

Susskind, L., Fuller, B. W., Ferenz, M., \& Fairman, D. (2003). Multistakeholder dialogue at the global scale. International Negotiation, 8, 235-266.

Takahashi, L. M., \& Smutny, G. (2001). Collaboration among small, communitybased organizations: strategies and challenges in turbulent environments. Journal of Planning Education and Research, 21, 141-153.

Taylor, E. W. (1997). Building upon the theoretical debate: a critical review of the empirical studies of Mezirow's transformative learning theory. Adult Education Quarterly, 48, 34-59.

Taylor, E. W. (1998). The theory and practice of transformative learning: A critical review (No. 374). Columbus, OH: ERIC Clearinghouse on Adult, Career, and Vocational Education. 
Taylor, E. W. (2001). Transformative learning theory: a neurobiological perspective of the role of emotions and unconscious ways of knowing. International Journal of Lifelong Education, 20(3), 218-236.

Tenkasi, R. V., \& Chesmore, M. C. (2003). Social networks and planned organizational change: the impact of strong network ties on effective change implementation and use. The Journal of Applied Behavioral Science, 39(3), 281-300.

Thacher, D. (2004). Interorganizational partnerships as inchoate hierarchies: a case study of the community security initiative. Administration and Society, 36(1), 91-127.

Thayer-Bacon, B. (2000). Transforming critical thinking: thinking constructively. NY: Teachers College Press.

Thompson, M. (2005). Structural and epistemic parameters in communities of practice. Organization Science, 16(2), 151-164.

Thomson, J. S., Radhakrishna, R. B., Maretzki, A. N., \& Inciong, L. O. (2006). Strengthening community engagement toward sustainable local food systems. Journal of Extension, 44(4).

Tisdell, E. (2000). The politics of positionality: teaching for social change in higher education. In R. Cervero \& A. Wilson (Eds.), Power in practice (pp. 145163). San Francisco, CA: Jossey-Bass.

Tisdell, E. (2003). Exploring spirituality and culture in adult and higher education. San Francisco, CA: Jossey-Bass.

Toothaker, L. E. (1993). Multiple comparisons procedures (Vol. 89). Thousand Oaks, CA: Sage Publications.

Trimbur, J. (1989). Consensus and difference in collaborative learning. College English, 51(6), 602-616.

Trist, E. (1983). Referent organizations and the development of inter-organizational domains. Human Relations, 36(3), 269-284.

Turcotte, M.-F., \& Pasquero, J. (2001). The paradox of multistakeholder collaborative roundtables. The Journal of Applied Behavioral Science, 37(4), 447-463.

Turning Point Leadership Development National Excellence Collaborative. (2001). Collaborative leadership and health: a review of the literature. Seattle, WA: University of Washington School of Public Health and Community Medicine.

Usher, R., Bryant, I., \& Johnston, R. (1997). Adult education and the postmodern challenge. New York, NY: Routledge.

Van Esterik, P. (1999). Gender and sustainable food systems: A feminist critique. In M. Koc, R. MacRae, L. J. A. Mougeot \& J. Welsch (Eds.), For hunger-proof cities. Ottawa, ON Canada: International Development Research Centre.

van Rossum, Z., \& Sole, D. (2006). Sources of collaborative capacity (No. 0406). Cambridge, MA: Harvard Graduate School of Education. 
Vangen, S., \& Huxham, C. (2003). Nurturing collaborative relations: building trust in interorganizational collaboration. The Journal of Applied Behavioral Science, 39(1), 5-31.

Vangen, S., \& Huxham, C. (2003). Enacting leadership for collaborative advantage: dilemmas of ideology and pragmatism in the activities of partnership managers. British Journal of Management, 14, s61-s76.

Waddell, S. (2005, November 21-23, 2005). Social integration: A global societal learning and change perspective. Paper presented at the Presentation to United Nations Department of Economic and Social Affairs Expert Group Meeting on Dialogue in the Social Integration Process: Building peaceful social relations by, for and with people New York, NY.

Waddock, S. A. (1989). Understanding social partnerships: an evolutionary model of partnership organizations. Administration and Society, 21(1), 78-100.

Waddock, S. A. (1991). A typology of social partnership organizations. Administration and Society, 22(4), 480-515.

Waddock, S. A. (1999). Linking community and spirit: a commentary and some propositions. Journal of Organizational Change and Management, 12(4), $332-344$.

Warner, J. (2005). Multi-stakeholder platforms: integrating society in water resource management? Ambiente and Sociedade, 8(2), 1-20.

Warner, J. F. (2006). More sustainable participation? Multi-stakeholder platforms for integrated catchment management. Water Resources Development, 22(1), 15-35.

Weisbord, M. (1992). Discovering common ground: how Future Search Conferences bring people together to achieve breakthrough innovation, empowerment, shared vision, and collaborative action. San Francisco, CA: Berrett-Koehler Publishers.

Weiss, E. S., Anderson, R. M., \& Lasker, R. D. (2002). Making the most of collaboration: exploring the relationship between partnership synergy and partnership functioning. Health Education and Behavior, 29(6), 683-698.

Welton, M. R. (Ed.). (1995). In defense of the lifeworld: critical perspectives on adult learning. Albany, NY: SUNY Press.

Wenger, E. C., \& Snyder, W. M. (2000). Communities of practice: The organizational frontier. Harvard Business Review, 139-145.

West, E. J. (2004). Perry's legacy: Models of epistemological development. Journal of Adult Development, 11(2), 61-70.

Westley, F., \& Vredenburg, H. (1997). Interorganizational collaboration and the preservation of global biodiversity. Organization Science, 8(4), 381-403.

Whelan-Berry, K. S., Gordon, J. R., \& Hinings, C. R. (2003). Strengthening organizational change processes: recommendations and implications from a multilevel analysis. The Journal of Applied Behavioral Science, 39(2), 186207. 
Winn, M. I., \& Keller, L. R. (2001). A modeling methodology for multiobjective multistakeholder decisions: Implications for research. Journal of Management Inquiry, 10(2), 166-181.

Wolff, T. (2001). A practitioner's guide to successful coalitions. American Journal of Community Psychology, 29(2), 173-190.

Wolff, T. (2001). Community coalition building-contemporary practice and research: introduction. American Journal of Community Psychology, 29(2), 165-172.

Woltjer, J. (2005). The multidimensional nature of public participation in planning: comment on Innes and Booher. Planning Theory and Practice, 6(2), 273276.

Wood, D. J., \& Gray, B. (1991). Toward a comprehensive theory of collaboration. Journal of Applied Behavioral Science, 27(2), 139-162.

Woolcock, M. (2004). Why and how planners should take social capital seriously. Journal of the American Planning Association, 70(2), 183-189.

Yaffee, S. L., \& Wondolleck, J. M. (2003). Collaborative ecosystems planning processes in the United States: evolution and challenges. Environments, 31(2), 60-72.

Yaffee, S. L., Wondolleck, J. M., \& Lippman, S. (1997). Factors that promote and constrain bridging: a summary and analysis of the literature. Ann Arbor, MI: The University of Michigan School of Natural Resources and Environment Ecosystem Management Initiative.

Yin. (1993). Applications of case study research (Vol. 34). Newbury Park: SAGE Publications.

Yin. (1994). Case study research: design and methods. Thousand Oaks, CA: SAGE Publications.

Yorks, L. (2005). Adult learning and the generation of new knowledge and meaning: creating liberating spaces for fostering adult learning through practitionerbased collaborative action inquiry. Teachers College Record, 107(6), 12171244.

Zald, M. N., \& Ash, R. (1966). Social movement organizations: growth, decay, and change. Social Forces, 44(3), 327-341.

Zelezny, L. C., Chua, P. P., \& Aldrich, C. (2000). New ways of thinking about environmentalism: elaborating on gender differences in environmentalism. Journal of Social Issues, 56(3), 443-457. 


\section{APPENDIX A: JUNE 2001 NEXT STEPS FORM}

Next Steps - Where from here?

Please check all that apply.

( I would like to serve as a Core Team member, collaborating in the proposal development and guidance of this regional initiative.

I I would like to provide feedback on proposal drafts and participate in the initiative when it begins.

- I would be interested in signing a letter of support for the initiative and participating in later projects.

( I am unable to make any commitments at this time: please keep me posted as the initiative develops.

( Other (please

explain) 


\section{APPENDIX B: KELLOGG FOUNDATION FOOD \& SOCIETY INITIATIVE}

From the W.K. Kellogg Foundation Website: www.wkkf.org. Current as of 10-03

Kellogg's Food and Society Initiative aims to "support the creation and expansion of community-based food systems that are locally owned and controlled, environmentally sound and health-promoting. Annually, the Food and Society initiative convenes a meeting of stakeholders which brings together community activists, business leaders, farmers ranchers, scholars and thought leaders to explore and discuss the community-based food system concept and its opportunity to improve rural communities, the environment and public health. Materials from the last two meetings including video, PowerPoint presentations and written material are available at www.foodandsociety.org.

\section{What types of projects will be part of the FAS Initiative?}

Projects will focus on three primary areas: market-based change, institutional support, and public policy. We believe in the importance of community-based models of successful food systems enterprises both to demonstrate that these kinds of enterprises are possible, and to exist as models to be adapted and adopted in other communities. We also believe that there needs to be a supportive infrastructure of university (and other institutional) support and public policy friendly to these kinds of communitybased enterprises in order for these enterprises to flourish and multiply.

\section{Projects likely to receive strong consideration will contain some of the following characteristics:}

* A focus on community impact and system-wide change;

* Methods and activities that bring together young people from diverse socioeconomic and ethnic backgrounds. 
* Participation from diverse individuals, populations and organizations;

* A focus on leadership development and capacity building; and,

* Demonstrated ability to secure funding to complement Kellogg Foundation support.

\section{What does the FAS Initiative expect to accomplish?}

* Raise the profile of and support for scientists and organizations working to support the creation and expansion of community-based food systems enterprises that are locally owned and controlled, environmentally sound, and health promoting.

* Broaden the agenda for scholarship at land-grant universities and other educational institutions to support communities and partners working to create and expand community-based food systems enterprises that are locally owned and controlled, environmentally sound and health-promoting.

* $\quad$ Support public policy that helps create and expand community-based food systems

* Increase the number of locally owned and controlled farms and other community-based food systems enterprises that utilize environmentally sound agricultural systems.

* Increase the number of economically successful food-related enterprises that utilize environmentally sound, health promoting and community-sustaining practices.

* Increase the number of donors and partners supporting community-based food systems enterprises that are locally owned and controlled, environmentally sound and health promoting. 


\section{APPENDIX C: FORUM INVITATION}

The invitation was a tri-fold document, with a tear-off, stamped and addressed RSVP card.

\section{You're invited to participate in...}

Growing a Regional Food Economy: A Forum for Promoting Good Jobs, Food Access, Environmental Stewardship, and Farm Viability

April 11-12, 2002

The Jean Vollum Natural Capital Center, Portland, Oregon

\section{What}

You have been invited to join a select group of leaders in launching Community Food Matters - a collaborative effort to sustain the Northern Willamette Valley/Portland region's food system and improve economic, environmental, and human health in urban and rural communities. We begin with a one-and-one-half day forum attended by growers, food industry leaders, development organizations, university partners, policymakers, and other community members. The forum agenda balances comprehensive presentations on regional food system issues with ample time for peer-to-peer learning and project development.

Our keynote speaker is Wes Jackson, President of The Land Institute, author of New Roots for Agriculture and Becoming Native to This Place, MacArthur Fellow, and recipient of the Right Livelihood Award. Other forum highlights include a participatory assessment of the region's food system, exploration of existing and proposed projects (e.g. expanding local markets, micro-enterprise and value-added, education and communication programs, and food policy councils), and next steps for the initiative.

\section{Why}

Food decisions can have a significant positive impact on local job development, natural resources, human health, and quality of life. Our region is served by a number of excellent public, for-profit, and non-profit efforts addressing facets of this issue, yet the whole remains less than the sum of its parts: Agriculture remains threatened, food access remains problematic, stewardship of natural resources remains to be strengthened, and community 
development opportunities go unfulfilled. Community Food Matters addresses this gap by bringing diverse community members together to increase our collective understanding of factors shaping the food system, and to collaborate in building a sustainable regional food system - both enhancing existing efforts and creating new strategies.

\section{How}

The forum will be held April 11th (9:00 to 5:00) and April 12th (9:00 to 2:00) at the Jean Vollum Natural Capital Center, 721 NW Ninth Avenue, Portland. We will host your snacks, lunches, and an opening reception. Space is limited and forum activities build upon each other; thus, it is important that participants commit to attending the full forum. Snacks, lunches, and an opening reception will be provided. The facility is ADA accessible. Please RSVP with the enclosed reply card by April 1, 2002. We are pleased to make this landmark event free through the generous sponsorship of The Oregon Economic and Community Development Department, New Seasons Market, Oregon Food Bank, and Ecotrust. Co-sponsors include Community Food Matters, The Food Policy Council Working Group, and the Coalition for a Livable Future's Food Policy Working Group. Wes Jackson is presented in partnership with Institute for the Northwest.

Community Food Matters is a coalition representing food production, food access, and community development sectors. Charter members include: Ecotrust, Oregon Department of Agriculture, American Farmland Trust, Chef's Collaborative, Coalition for a Livable Future Food Policy Working Group, Agri-Business Council of Oregon, Mercy Enterprise Corporation, Oregon Food Bank, City of Portland, Oregon Economic and Community Development Department, Growing Gardens, Portland State University, Oregon State University, Ecumenical Ministries of Oregon - Interfaith Network for Earth Concerns, New Seasons Market, Washington State University, Zero Waste Alliance, The Food Alliance, and Friends of Zenger Farms. 


\section{R.S.V.P.}

Please RSVP by April 1. We ask that you commit to attending the full event to enhance the forum's effectiveness. Space is limited to 100 , so reply ASAP to hold your space. Please check if applicable:

Yes, I will attend the Forum, April 11 th and 12th.

[ I am interested in attending but cannot make it. Please inform me of future news and events.

( I I am not interested in participating in the Forum or other regional food economy events.

D Dietary restrictions or special accommodations:

[ I am interested in space in the resource room to share information about my organization.

- My space requirements would best be served by

Through a special partnership with Institute for the Northwest, we are pleased to offer a complimentary ticket to Wes Jackson's lecture "Going Native: Natural Systems Agriculture" at 7:30 pm on April 10th. This lecture will focus on Wes' lifework of developing an agriculture based on native ecosystems, and will be an excellent kick-off to the forum. Wes' participatory keynote at the forum on April 11th will emphasize local food economies.

Y Yes, please send me a ticket along with my registration materials.

] No, I am unable to attend, save the ticket for someone else.

My name:

My organization:

Mailing address:

E-mail:

Phone:

Primary food system interests:

Questions about registration? Contact Kara Orvieto at 503-467-0758.

Questions about the forum or initiative? Contact Stuart Cowan at

503-467-0773, stuart@ecotrust.org or Janet Hammer at 503-725-4019, hammerj1@pdx.edu. 


\section{APPENDIX D: BUILDING A REGIONAL FOOD ECONOMY FORUM EVALUATION}

Please complete the following questionnaire - front and back. All responses are confidential and there are no right or wrong answers. Your feedback will be very helpful! If you have any questions, please contact our evaluation coordinator, Janet Hammer, at 503-725-4019.

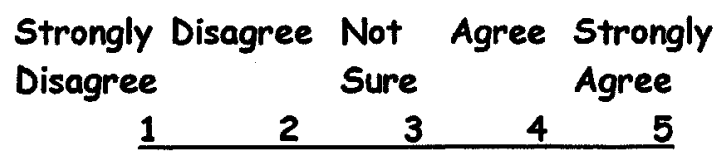

$\begin{array}{lllllll}\text { Overall, I found this Forum to be worthwhile. } & 1 & 2 & 3 & 4 & 5\end{array}$

I made contacts that will be helpful to my work. $\quad \begin{array}{llllll}1 & 2 & 3 & 4 & 5\end{array}$

$\begin{array}{llllllll}\text { The Forum provided a good start to building a } & 1 & 2 & 3 & 4 & 5\end{array}$ shared vision for the region's food system.

The issues being discussed were relevant to me. $\begin{array}{lllllll}1 & 2 & 3 & 4 & 5\end{array}$

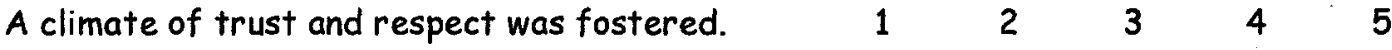

$\begin{array}{lllllll}\text { Most Forum participants seemed to listen } & 1 & 2 & 3 & 4 & 5\end{array}$ sincerely to each other.

I felt that I had the opportunity to be heard. $\quad \begin{array}{lllllll} & 1 & 2 & 3 & 4 & 5\end{array}$

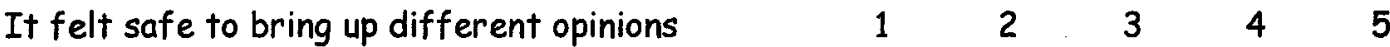
or to disagree.

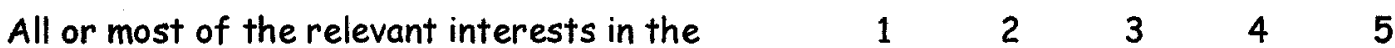
region's food system were represented at the forum.

Overall, it seemed that there was enough time $\quad \begin{array}{llllll}1 & 2 & 3 & 4 & 5\end{array}$ for each of the activities.

I felt engaged through all or most of the Forum. $\quad \begin{array}{llllll}1 & 2 & 3 & 4 & 5\end{array}$ 
Prior to this Forum I had a high level of

$\begin{array}{lllll}1 & 2 & 3 & 4 & 5\end{array}$

knowledge about regional food system issues.

$\begin{array}{lllllll}\text { At the Forum I increased my understanding } & 1 & 2 & 3 & 4 & 5\end{array}$

about the health of this region's food system.

$\begin{array}{lllllll}\text { Participating in the Forum helped me clarify my } & 1 & 2 & 3 & 4 & 5\end{array}$

own beliefs and values about sustainable food systems.

$\begin{array}{llllllll}\text { The facilities were comfortable. } & 1 & 2 & 3 & 4 & 5\end{array}$

The open space break-out group that I participated in was titled

This break-out group time was (please circle one):

4

Very Worthwhile Worthwhile

A Little Worthwhile Not Very Worthwhile

In what ways do you think that attending this Forum will impact you professionally?

In what ways do you think that attending this Forum will impact you personally?

The best things about the Forum were...

Areas for improvement include...

Your name is optional, but would be helpful in case we have any follow-up questions. All responses are confidential and there are no right or wrong answers.

Name: 


\title{
APPENDIX E: FORUM NEXT STEPS FORM
}

\author{
Community Food Matters: Next Steps
}

My name is

You can reach me by phone at and by email at

Please check all that apply regarding the Community Food Matters initiative.

I would consider serving on the Core Leadership Team. This group of approximately 10 to 15 individuals will be responsible for managing the initiative.

- I am interested in working on specific projects. My main project interests include:

- I would attend semi-annual events that feature speakers and in-depth discussion on key issues, time for work groups to meet, resource sharing, and new product launching (with Chef demonstrations).

- Please add me to the email listserv for Community Food Matters.

Community Food Matters aims to improve the economic, environmental, and sociocultural health of urban and rural communities in the Portland metropolitan region through the development of sustainable community food systems.

In your opinion, how valuable will it be to have a center for sustaining regional food systems whose activities include: 1) collecting and disseminating assessment data on the health of the region's food system, 2) facilitating the coordination of information and other resources on regional food system issues, and 3) helping to incubate projects that support a sustainable regional food system. Please circle one of the following:

1 Very valuable

2 Valuable

3 Not valuable

4 Not sure

How could Community Food Matters, a regional center for sustaining food systems, support your work?

What other feedback do you have regarding the idea of a regional center for sustaining food systems?

Thank you for your feedback. Your input is much appreciated. 


\section{APPENDIX F: FOLLOW-UP EMAIL COMMUNICATION}

May 10, 2002

Greetings. The enclosed is an update from the "Building A Regional Food Economy Forum" held April 11th and 12th, and a description of how you can remain (or become) involved. I have attached the draft strategy for the CFM initiative for your information.

The Forum was a great success and Community Food Matters is officially launched. As you are aware, CFM aims to improve the economic, environmental, and human health of rural and urban communities in the region through the development of sustainable community food systems. A Launch Team of 10 to 15 individuals is serving as the interim management team for this launch phase of the initiative (listed below). We have defined a portfolio of four program areas that, together, make a coherent strategy for addressing sustainability of the region's food system. The four program areas (teams) include:

- Food economy entrepreneurship

- Expanded and enhanced markets

- Community food literacy and policy work

- Food system assessment.

As detailed in the attached draft strategy, each program area will include a number of complementary projects. This portfolio was developed based on the work of the initial Core Team as well as input at the Forum. The Launch Team is defining a work plan and budget for this initial portfolio of programs and will be seeking funds over the next few months.

What to do?

1. If you are interested in participating on a particular team or project let me know.

2. If you have suggestions about funding sources, please pass that along.

3. If you do not want to remain on the Community Food Listserv, let me know. The listserv is our way of staying in touch - announcing important events, opportunities, and meetings.

4. I will send the minutes from the Forum report-outs in a separate email. Feel free to follow up on specific contacts or ideas.

5. If you need contact information, let me know.

6. Keep up the great work!

You are all doing such wonderful things to support the health of our region's food system. I thank you for your efforts and look forward to the coming conversations and collaborations.

On behalf of Community Food Matters, Janet Hammer 


\section{APPENDIX G: DRAFT GOVERNANCE STRUCTURE}

\section{$\underline{\text { BOARD }}$}

The Board has full charge accountability for CFM. This is a non-paid board.

\section{DIRECTOR}

The Director reports to the Board, facilitates and works with the Coordinating Council, makes recommendations to the Board based on input from the Coordinating Council members. The Director is paid by CFM.

\section{COORDINATING COUNCIL}

All Project Team Leaders serve on the Coordinating Council. Council members are likely CFM staff or representatives of CFM Partner organizations. Council members may or may not be paid by CFM. Projects may be partially or wholly funded by CFM.

\section{PROJECT TEAMS}

The projects are the core programs of Community Food Matters. Projects may involve multiple partners and be very cross functional and cross organizational. Project Teams are led by Project Team Leaders.

\section{PARTNERS}

Partners publicly engage and endorse Community Food Matters, identifying what resources they are dedicating to the organization. It is assumed that the CFM projects that the Partners participate in are core projects for the Partner organization.

\section{COMMUNITY FOOD MATTERS NETWORK}

Anyone that is interested in food in our region can be a part of the Community Food Matters Network, working to support Community Food Matters concerns. 


\section{APPENDIX H: DRAFT CONCEPT PAPER, MAY 2002}

\section{OVERVIEW}

The Community Food Matters initiative aims to improve the economic, environmental, and socio-cultural health of urban and rural communities in the Portland metropolitan region through the development of sustainable food and farm systems. The region at this time is defined as eaters in the Metro region and producers within a half day to one-day drive. Though the region is served by a number of public, for-profit, and non-profit initiatives addressing facets of community food system issues, the whole is less than the sum of its parts: agriculture viability is threatened, food access and hunger continue to plague us, stewardship of natural resources remains problematic, and community development opportunities go unfulfilled.

Community Food Matters has developed an integrated portfolio of programs that, together, support the creation and expansion of community-based food systems that are locally owned and controlled, environmentally sound and health-promoting. Projects will leverage existing resources and recruit additional resources in order to both enhance extant efforts and develop new strategies that support a sustainable community food system. Community Food Matters fills a unique niche, drawing on the distinct talents and resources of private, governmental, and non-governmental partners to articulate and implement a comprehensive strategy for improving community food systems. The effort is well positioned for success as it meets a recognized need, involves the diversity of food system partners, and builds on existing strengths and lessons learned. The following paragraphs introduce the proposed structure and programs for Community Food Matters (CFM). 


\section{PROGRAM PORTFOLIO}

CFM has developed a portfolio of programs and projects that, together, make a coherent and compelling strategy for promoting a sustainable local food system. While a number of worthy projects have been identified, we will focus our efforts initially in order to maximize efficiency and impact. Programs, as detailed below, include food economy entrepreneurship, expanded and enhanced markets and marketing, community food literacy and policy work, and community food system assessment.

\section{Food Economy Entrepreneurship}

The Portland Metropolitan region enjoys a growing reputation in both the food and sustainable development communities. However, the full potential of the food economy in this region has yet to be realized. Addressing identified gaps to capitalizing on local assets, this project will increase the amount of local value-added food products developed and sold, improve industry sector linkages, and promote economic and environmental sustainability practices of food entrepreneurs. Benefits include increased employment in the food economy and income generation through new product development, improved access to markets, and cost saving and value added opportunities associated with stewardship practices.

Project objectives include provision of training and technical assistance on food economy entrepreneurship (including sustainability practices), development of a revolving loan fund for food entrepreneurship, and increased utilization of existing food processing, distribution, and marketing capacity. The project includes five strategic components that respond to barriers and opportunities to enhanced competitiveness of the region's food economy:

Food Processing and Preparation Facilities -- Assess existing capacity and availability of food processing and food preparation facilities, assess food 
entrepreneurs' production facility needs, promote efficient utilization of these facilities by disseminating information on existing resources and needs, and develop a collaborative strategic response to identified gaps.

Food Distribution Channels -- Assess existing distribution channels (e.g., distributors, farmer markets, restaurants, retailers), assess the distribution needs of food entrepreneurs, promote efficient utilization of the different distribution channels by disseminating information on existing resources, and develop a collaborative strategic response to identified gaps.

Technical Assistance -- Provide workshops and one-on-one assistance to food entrepreneurs on the topics of product development, food safety, environmental management and waste reduction, business planning, marketing, sourcing of local product, and other sustainable food system issues.

Revolving Loan Program -- Establish revolving loan fund program for food entrepreneurs that is based on best practices in the micro and small business loan industry (e.g., required monthly meeting with food business advisor and other compliance and screening procedures). Including low income, youth, and immigrant populations.

Enhanced Marketing and Value-Chain Linkages -- Support successful product launching by connecting value-added food entrepreneurs with vendors through sponsored events and improved industry linkages.

This program unites expertise in workforce and community economic development, micro credit and revolving loan funds, small business development, farm viability, and food entrepreneurship. This collaborative endeavor draws on the distinct talents and resources of private, governmental, and non-governmental partners to articulate and implement a regional competitiveness strategy that links economic and community development efforts to enhance livability in the region. 


\section{Expanded and Enhanced Markets and Marketing}

Integrally linked to the Food Economy Entrepreneurship program discussed above, this effort focuses on building local recognition and purchase of local, sustainable products. This is accomplished via:

Enhancement and Expansion of Farmer Markets - Farmers Markets are growing in this region however some areas remain underserved, and market space remains tenuous. This project supports the establishment of permanent farmers markets sites designed with the appropriate features necessary to facilitate market efficiency and safety (e.g., loading, water, storage). This includes existing areas vulnerable to loss of market space, underserved communities, and the proposed year-round Public Market. Value Added and Season Extension - Opportunities exist for growers to enhance sales through season extension, diversification, and certification. This project will provide funds and technical assistance to assist with season extension, diversification, certification, and/or value-added processing.

The Food Web -- Serving journalists, vendors, and consumers, this on-line downloadable database will feature stories about growers and their product as well as information on sourcing local product.

Building Local Markets - As per the Food Economy piece described above, Community Food Matters' semi-annual product launch events feature local, sustainable product and promote linkages through the value chain (e.g., growers, processors, marketers). Buy local campaign in the region will also be conducted, connected to the website (above) and existing buy local campaigns (e.g., Portland's Bounty, Farm-Chef Connection).

Alternative to Candy Sales -- Connected to the education effort, this project features school sales of local product (the alternative to candy sales) tied with field trips to the farm.

Institutional purchasing - Institutional purchases significantly impact the local food economy. This component will identify barriers and opportunities to increasing 
institutional purchases (e.g., schools, hospitals, government agencies, large businesses) and develop strategies in response to findings.

\section{Community Food Literacy and Policy Work}

Support for a regional food system is predicated, in part, upon a food literate population. This program defines a strategy for increasing food system literacy and food growing skills among youth and adult community members. It also targets specific efforts to policy makers.

Youth - Youth will learn about growing food, develop an understanding of food system issues, and define a sense of their place in the community food system. This includes hands on gardening experience, community based learning, and assessment activities that feed into the larger CFM assessment component (below).

In School: Food from the Playground - three to four sites where children learn to grow food, receive curriculum about food system issues, and participate in a food system assessment in their neighborhood.

Training for Educators - a continuing ed unit that includes site visits for educators to learn about food system education opportunities and methods of incorporating into their curriculum.

Out of School: Coordinated and enhanced strategy between Zenger, Growing Gardens, Old McDonald, Tilth, and others. Ties into Learning Community (below) and, where possible, to other program areas (e.g., food economy entrepreneurship, assessment, expanded markets).

Adult Food Skills - Hunger and poor nutrition continue to plague our community. This project will provide access to food growing opportunities, and will provide training in food preparation and storage. The program supports the installation of home gardens to low income families and coordinates programs on seed saving, 
preserving, and preparation both in program delivery and in outreach (e.g., web presence, newsletters). Where possible, links are made to other program areas (e.g., food economy entrepreneurship, assessment, expanded markets).

Community Events - A Harvest Festival/Food Day Event will be held throughout the region to increase awareness of community food issues and celebrate the region's food system. Inspired by models of decentralized collaboration such as Earth Day celebrations and Washington's Harvest Celebration, this festive and educational "event" includes a variety of activities held in many places designed for diverse audiences. This includes, for example, chef demos, service learning, workshops, arts and celebrations. The event will be coordinated with existing efforts such as $\mathrm{ABCs}$ October event and INEC's Place at the Table.

Policy Maker Learning - Outreach and education with policy makers will be conducted to increase their understanding of, and support for, sustainable community food systems. This may include support to the new food policy council, and development of statewide policy effort. This effort includes links to assessment and other program areas such as institutional purchasing and policies that support sustainable community food systems.

Community Food Literacy Learning Community and Resource Library - The Education Team will act as a Learning Community and resource hub: identifying existing resources; sharing information, lessons learned, and materials; and defining areas where their programs can be enhanced through collaboration on development and implementation of curricular materials. 


\section{Food System Assessment}

Though community food system issues have captured increasing attention by academicians and practitioners there is a dearth of information on methodologies for assessing and mapping sustainability/health of community food systems. This information is critical both for identifying key leverage points, tracking food system health, and evaluating project impacts.

The program unites University researchers and community practitioners in defining and implementing a regional food system assessment including environmental, economic, and social dimensions. This includes for example, flows between sectors of the region's food system, adoption of sustainability practices in various food system sectors, relationships between social capital and healthy food systems, impact of food economy entrepreneurship as a community development strategy, access to nutritious affordable food, food skills, food literacy, and health outcomes. Examples of the range of variables that may be considered include:

Eaters - food access and choices in specific populations; health outcome links to community food system features; food system impacts on sense of community and social capital; conceptualization of sustainable community food systems; percent of regional food dollars spent on local products.

Growers - what is grown; where product goes; agroecological health; farm profitability; access to markets and value added opportunities; percent of locally grown product consumed locally; land tenure and access; farmer and farm worker health and well-being (accidents, exposures, pay, living conditions, etc.).

Processing/Distribution/Serving - source of inputs; distribution of product; type and amount of waste; local ownership; health, sense of community, social capital, and conceptualization of sustainable community food systems. 


\section{APPENDIX I: FINAL CONCEPT PAPER, FEBRUARY 2004}

The purpose of this grant is to improve food system sustainability in Oregon and Southern Washington through an integrated approach to market development, policy change, and community capacity building. Our two- year funding request totals $\$ 790,000$.

The mission of Community Food Matters (CFM), a coalition of food organizations and activists hosted by Ecotrust, is to improve economic, environmental, and human health in urban and rural communities in the region through the development of sustainable food systems. ${ }^{1}$ Community Food Matters supports the creation and expansion of community-based food systems that are locally owned, environmentally sound and health-promoting.

Community Food Matters (CFM) is a coalition of private, public, and nongovernmental partners representing food production, food access, and community development sectors. CFM is hosted by Ecotrust and governed by an Advisory Board including representatives of Agri-business Council of Oregon, City of Portland, Ecotrust, Friends of Zenger Farm, Metro, Oregon Food Bank, Oregon State University

\footnotetext{
${ }^{1}$ CFM currently defines its region as eaters in the six county SMSA (Clackamas, Columbia, Multnomah, Yamhill, and Washington in Oregon and Clark in Washington State) and growers in Oregon and southern Washington. Over time, we plan to move to a more bioregional model. Sustainable food products are made with attention to natural resource stewardship, human and community well-being, and economic viability.
} 
(OSU)/Oregon Department of Agriculture (ODA) - Food Innovation Center, OSU Extension Service, Oregon Tilth, Portland State University (PSU), Washington State University NW Direct, and The Food Alliance.

Founded in April 2002 with direction from key leaders in the region's food system, Community Food Matters was borne of a need to provide a collaborative, systemic response to problems facing the region's food system. After engaging community input and undertaking careful deliberation, the Advisory Board defined four priority areas for collaboration:

Market Connections - Support emerging regional sustainable food entrepreneurs with technical, financial, and marketing assistance needed to start or strengthen product ventures.

State of the Region's Food System - Develop a collaborative vision for the region's food system and a State of the Food System report that will be used to define action priorities, measure progress, and communicate with the public and policymakers. Policy Support - Provide technical support to policymakers regarding sustainable regional food system issues.

Community Capacity Building - Establish a network infrastructure to enhance key leader and public capacity to address sustainable food system issues. 
These four program areas comprise an integrated effort to address key issues identified by industry leaders as critical for achieving a sustainable regional food system.

\section{DESCRIPTION OF INITIATIVES}

\section{Program Area One: Market Connections $\mathbf{( \$ 5 5 , 0 0 0 )}$}

The objective of the Market Connections program is to increase the number of regional food entrepreneurs successfully marketing sustainable food products. Phase One of this effort is a feasibility study for a Sustainable Food Entrepreneur project that enhances entrepreneurial capacity to develop and sell locally and sustainably produced food products by connecting emerging food entrepreneurs with the technical, financial, logistical, and managerial resources necessary for successful product launch or expansion.

The OSU-ODA Food Innovation Center (FIC) and Ecotrust's Food and Farms Program are lead partners in this effort to grow regional food entrepreneurs in the value-added sustainable food sector. In cooperation with other CFM partners, the FIC and Ecotrust will explore the feasibility of a social enterprise venture that provides a range of business development services designed to increase earning opportunities for locally based, sustainable food entrepreneurs. Offered on a fee for service, commission, or negotiated royalty income basis, these services may include assistance with product development, marketing, business management, financing, product 
fulfillment, and access to distribution channels. Select entrepreneurs would have access to a council of regional retailers who agree to test-market their products and provide customer and buyer feedback.

This economic and community development project responds to the troubled commodity-focused industrial food system that is failing the small and mid-sized food producers. Oregon has lost numerous food processing plants in the past decade, disenfranchising many local farming, ranching and fishing communities. Yet, sustainability focused food manufacturers and processors across the region are proving that there are excellent opportunities to take advantage of Oregon's highly productive land, climate, waters, and urban markets for de-commodified food products.

Testimony and inquiry lead us to believe that current business development services in the region do not adequately address the needs of the emerging sustainable food entrepreneur. A Sustainable Food Entrepreneur venture can enhance the capacity of this population to develop and sell locally and sustainably produced food products by addressing their unique market entry challenges - be that product development, brand development, access to finances, or access to retail and e-commerce distribution channels. This feasibility study will identify critical requirements for design and implementation of a successful Sustainable Food Entrepreneur venture. 


\section{Program Area Two: State of the Region's Food System}

The objective of the State of the Region's Food System program is to define a collaborative vision for the region's food system and provide relevant, user-friendly information needed to identify food system leverage points, implement policy change, communicate with consumers and decision-makers about food system issues, and measure progress towards sustainable food system objectives. The funding request for this program area supports two projects: development of a regional sustainable food system vision and indicators, and a community based participatory mapping of food access, beliefs and behaviors.

\section{Northwest Food System Vision $(\$ 55,000)$}

Critical to the achievement of a sustainable food system is the development of a region-wide shared vision, coupled with indicators for assessing progress over time. Much like the Roots of Change Fund-sponsored Vivid Picture project in California, the Northwest Food System Vision project would convene diverse stakeholders to collaborate in defining a vision for the food system of Oregon and Washington and indicators for assessing progress over time. Utilizing existing data, the "picture" will include economic, environmental, and social dimensions of the food and farm system and will serve as a focal point for defining regional policy and program priorities. Project partners will collaborate in sharing the "picture" with constituents, key leaders, and policymakers in a variety of venues including CFM sponsored forums, appearances at industry and community-based events, and on the web. This funding 
request is for an exploratory Phase I project. Phase I will establish sustainable food system stakeholder and funder groups. In addition, Phase I will focus on development of workplan. Members of the Community Food Matters team have long and deep relationships with key food system stakeholders in the Northwest and can serve as the convener of such a project.

Metro Community Food Map $(\$ 310,000)$

The Metro Community Food Map project responds to information needs identified by CFM, the Portland/Multnomah Food Policy Council, and the Coalition for a Livable Future Regional Equity Atlas Project. The Metro Community Food Map fills significant data gaps that hinder the ability of policymakers, community members, and engaged regional organizations to effectively implement and evaluate community food initiatives.

The Metro Community Food Map project is a community-based, participatory effort that utilizes Geographic Information Systems (GIS) mapping, surveys, and focus groups to identify who in the metro community has access to what types of foods at what quality and price, while also documenting food system attitudes, behaviors, and associated health outcomes. Working with the Portland-Multnomah Food Policy Council, the Coalition for a Livable Future, and Portland State University, CFM will lead a team of practitioners, researchers, and community-based partners in the collection, analysis and dissemination of quantitative and qualitative information 
about community food issues. This pilot project targets a four-county sub-region and considers various sub-populations (e.g., geographic, socio-economic, ethnic). The effort builds upon, and contributes to, a national and international dialogue about best practices in community food mapping.

Findings will be disseminated to policy makers and community members through a range of media including briefings and events (e.g., forums, presentations) as well as other print and web-based reports and brochures. The findings will be used to define priority governmental and non-governmental action (e.g., social marketing messages, market-siting, transportation linkages, food growing opportunities), and to establish baseline information crucial for monitoring and evaluation of food system changes and policy and project impacts. In addition, the lessons learned from this pilot will inform future community food mapping efforts in the region. Further, the community food mapping provides an opportunity to "ground truth" some of the assumptions and indicators about capacity and equity issues used in the Northwest Food System Vision Project: while the Northwest Food System Vision project utilizes existing data to develop a macro-level picture of the food system, the Metro Community Food Map project paints a picture with finer detail. Finally, the participatory process used in mapping food access, attitudes, behaviors and outcomes will contribute to communitybased education and collaboration on food system issues. 


\section{Program Area Three: Policy Support $(\$ 165,000)$}

The objective of the Policy Support program area is to increase policymaker understanding and support for regional sustainable food system issues. Policy plays a vital role in supporting or impeding sustainable food system efforts, yet the Northwest region lacks the infrastructure to successfully address sustainable food system policy. The City of Portland/Multnomah County Food Policy Council's recently approved recommendations require technical support for successful implementation. Other cities and counties in the region have not yet begun to assess or respond to food system issues. The region is in the grip of a severe economic crisis, yet economic development specialists rarely consider potential food system contributions to sustainable community and economic development. Policymakers and staff who do take an interest in sustainable food systems are often unsure of where to get information or how to proceed.

Community Food Matters will respond to these gaps by providing outreach and technical assistance to policymakers and staff. Outreach includes one-on-one meetings, briefings and presentations, and regional bus tours with policymakers and staff that feature presentations from key leaders in the food system (e.g., producers, processors, retailers, anti-hunger specialists). The objective of the outreach effort is to elevate policymaker awareness of community food system issues and build understanding of and support for sustainable food system initiatives. Technical assistance will be provided to policymakers and staff regarding implementation of 
specific sustainable food system initiatives. This includes, but is not limited to, guidance in implementing the Portland/Multnomah Food Policy Council recommendations on market development, institutional purchasing, land use, economic development, food system assessment, and community based education.

\section{Program Area Four: Community Capacity Building $\mathbf{( \$ 2 0 5 , 0 0 0 )}$}

The objective of this program is to build community capacity to effectively engage in collaborative learning and action supportive of a sustainable regional food system. Research has shown that Community Food Matters' pilot efforts to convene colleagues and community members for networking, collaboration, and community learning has filled an important gap in the community. Interviews with key leaders and surveys of CFM participants have documented increased understanding of regional food system issues and expanded and enhanced collaboration. In response to participant feedback, CFM will implement a two-part strategy to enhance the networking capacity needed to support effective implementation of CFM goals and objectives.

First, CFM will host quarterly forums on key food system issues that include time for collaborative problem-solving and highlight sustainable food entrepreneur product launches and new initiatives. Forum topics will support program areas (e.g., a forum on assessment or food entrepreneurship) and will also respond to communityidentified interests (e.g., a forum on land use, institutional purchasing, or impacts of 
global trade agreements). Second, CFM will disseminate pertinent information regarding regional food system issues via the CFM listserve and a quarterly newsletter. Together, these "real" and "virtual" community gathering points provide opportunities for learning and networking that build key leader and community capacity to understand and address regional sustainable food system issues.

This concept paper articulates a coherent, systemic response to food system issues in the Northwest. An outgrowth of careful deliberation among diverse leaders in the region's food system, the defined programs address critical leverage points in marketing, policy, and community capacity. Implementation of these programs establishes the foundation necessary to achieve a sustainable regional food system. Specifically, this initiative will:

- Enhance capacity to launch and expand sustainable food enterprises

- Define a vision for the region's food system and a metric to assess movement toward the vision

- Increase policymaker understanding of and commitment to sustainable regional food systems

- Improve community capacity to effectively collaborate in building knowledge and partnerships supportive of a sustainable regional food system. 
Key Personnel responsible for implementation of this initiative are as follows: Janet Hammer, Director, Community Food Matters

Eileen Brady, Vice-President, Ecotrust Food and Farm Program

John Henry Wells, Superintendent, OSU Food Innovation Center

Rosemarie Cordello, Co-Chair Portland/Multnomah Food Policy Council

Additionally, staff from each of CFM's core partner organizations (Advisory Board described above) will be contributing to the initiative. New hires will be required for the Sustainable Food Entrepreneur Feasibility Study (6 month contract) and the State of the Food System Program (6 month contract Vivid Picture; 2 FTE staff and 4 interns for Community Food Mapping). 


\section{APPENDIX J: SURVEY ONE}

Thank you for agreeing to complete this questionnaire. It will take approximately 30 minutes to complete. A stamped-addressed return envelope has been provided. If you have any questions, do not hesitate to contact Janet Hammer at 503-725-4019.

Remember that there are no right or wrong answers and that all information is confidential (no response will be attributed to a specific person or organization). This information will help us better understand community food system issues in our region.

For this section, please rate the degree to which you agree or disagree with each of the following statements.

Remember that there are no right or wrong answers.

CIRCLE ONE response for each question, from strongly disagree to strongly agree.

1. Our current food system is ecologically sound.

\begin{tabular}{|c|c|c|c|c|c|c|}
\hline $\begin{array}{l}\text { Strongly } \\
\text { Disagree }\end{array}$ & Di & $\begin{array}{l}\text { Mildly } \\
\text { Disagree }\end{array}$ & $\begin{array}{l}\text { No } \\
\text { Sur }\end{array}$ & Mildly & Agree & $\begin{array}{l}\text { Strongly } \\
\text { Agree }\end{array}$ \\
\hline
\end{tabular}

2. Our current food system is socially just.

\begin{tabular}{|c|c|c|c|c|c|}
\hline $\begin{array}{l}\text { Strongly } \\
\text { Disagree }\end{array}$ & Disagree & $\begin{array}{l}\text { Mildly } \\
\text { Disagree }\end{array}$ & $\begin{array}{l}\text { Not } \\
\text { Sure }\end{array}$ & $\begin{array}{l}\text { Mildly } \\
\text { Agree }\end{array}$ & Agree \\
\hline
\end{tabular}

3. Our current food system promotes community health.

$\begin{array}{lllllll}\text { Strongly } & \text { Disagree } & \begin{array}{l}\text { Mildly } \\ \text { Disagree }\end{array} & \begin{array}{l}\text { Not } \\ \text { Sure }\end{array} & \begin{array}{l}\text { Mildly } \\ \text { Agree }\end{array} & \text { Agree } & \begin{array}{l}\text { Strongly } \\ \text { Agree }\end{array}\end{array}$


4. In general, I make healthy food choices.

$\begin{array}{lllllll}\text { Strongly } & \text { Disagree } & \text { Mildly } & \text { Not } & \text { Mildly } & \text { Agree } & \text { Strongly } \\ \text { Disagree } & & \text { Disagree } & \text { Sure } & \text { Agree } & & \text { Agree }\end{array}$

5. It's important that agriculture remains in our region.

$\begin{array}{lllllll}\text { Strongly } & \text { Disagree } & \text { Mildly } & \text { Not } & \text { Mildly } & \text { Agree } & \text { Strongly } \\ \text { Disagree } & & \text { Disagree } & \text { Sure } & \text { Agree } & & \text { Agree }\end{array}$

6. Hunger is a significant issue in our region.

\begin{tabular}{|c|c|c|c|}
\hline $\begin{array}{l}\text { Strongly } \\
\text { Disagree }\end{array}$ & Disagree & $\begin{array}{l}\text { Mildly } \\
\text { Disagree }\end{array}$ & $\begin{array}{l}\text { Not } \\
\text { Sure }\end{array}$ \\
\hline
\end{tabular}

7. Many farmers in the Northwest are having a tough time staying in business.

$\begin{array}{lllllll}\text { Strongly } & \text { Disagree } & \text { Mildly } & \text { Not } & \text { Mildly } & \text { Agree } & \text { Strongly } \\ \text { Disagree } & & \text { Disagree } & \text { Sure } & \text { Agree } & & \text { Agree }\end{array}$

8. In general, when I shop, prices for locally grown food are about the same as prices for non-locally grown food.

\begin{tabular}{|c|c|c|c|c|c|}
\hline $\begin{array}{l}\text { Strongly } \\
\text { Disagree }\end{array}$ & Disagree & $\begin{array}{l}\text { Mildly } \\
\text { Disagree }\end{array}$ & $\begin{array}{l}\text { Not } \\
\text { Sure }\end{array}$ & Mildly & Agree \\
\hline
\end{tabular}

9. In general, when I shop, prices for organic and sustainably grown food are about the same as prices for other food.

$\begin{array}{lllllll}\text { Strongly } & \text { Disagree } & \text { Mildly } & \text { Not } & \text { Mildly } & \text { Agree } & \text { Strongly } \\ \text { Disagree } & & \text { Disagree } & \text { Sure } & \text { Agree } & & \text { Agree }\end{array}$

10. Small, local businesses and national corporations are equally viable in our current food system.

\begin{tabular}{|c|c|c|c|c|}
\hline $\begin{array}{l}\text { Strongly } \\
\text { Disaggee }\end{array}$ & Disagree & $\begin{array}{l}\text { Mildly } \\
\text { Disagree }\end{array}$ & $\begin{array}{l}\text { Not } \\
\text { Sure }\end{array}$ & $\begin{array}{l}\text { Mildly } \\
\text { Agree }\end{array}$ \\
\hline
\end{tabular}


11. Government policies related to transportation, community development, and the environment all affect community food systems.

$\begin{array}{lllllll}\text { Strongly } & \text { Disagree } & \text { Mildly } & \text { Not } & \text { Mildly } & \text { Agree } & \text { Strongly } \\ \text { Disagree } & & \text { Disagree } & \text { Sure } & \text { Agree } & & \text { Agree }\end{array}$

12. The benefits of globalization outweigh the costs.

$\begin{array}{lllllll}\text { Strongly } & \text { Disagree } & \text { Mildly } & \text { Not } & \text { Mildly } & \text { Agree } & \text { Strongly } \\ \text { Disagree } & & \text { Disagree } & \text { Sure } & \text { Agree } & & \text { Agree }\end{array}$

13. Most people have the knowledge to plant and harvest their own garden.

$\begin{array}{lllllll}\text { Strongly } & \text { Disagree } & \text { Mildly } & \text { Not } & \text { Mildly } & \text { Agree } & \text { Strongly } \\ \text { Disagree } & & \text { Disagree } & \text { Sure } & \text { Agree } & & \text { Agree }\end{array}$

14. I have the knowledge and skills to make healthy food choices.

$\begin{array}{lllllll}\text { Strongly } & \text { Disagree } & \text { Mildly } & \text { Not } & \text { Mildly } & \text { Agree } & \text { Strongly } \\ \text { Disagree } & & \text { Disagree } & \text { Sure } & \text { Agree } & & \text { Agree }\end{array}$

15. My food choices make a difference to the local economy.

$\begin{array}{lllllll}\text { Strongly } & \text { Disagree } & \text { Mildly } & \text { Not } & \text { Mildly } & \text { Agree } & \text { Strongly } \\ \text { Disagree } & & \text { Disagree } & \text { Sure } & \text { Agree } & & \text { Agree }\end{array}$

16. Most people are knowledgeable about how their food choices impact the local economy and environment.

$\begin{array}{lllllll}\text { Strongly } & \text { Disagree } & \text { Mildly } & \text { Not } & \text { Mildly } & \text { Agree } & \text { Strongly } \\ \text { Disagree } & & \text { Disagree } & \text { Sure } & \text { Agree } & & \text { Agree }\end{array}$

17. Children's education should include basic knowledge and skills about growing and preparing food, and the impacts of food choices on themselves, their community, and the environment.

$\begin{array}{lllllll}\text { Strongly } & \text { Disagree } & \text { Mildly } & \text { Not } & \text { Mildly } & \text { Agree } & \text { Strongly } \\ \text { Disagree } & & \text { Disagree } & \text { Sure } & \text { Agree } & & \text { Agree }\end{array}$


18. Our region is losing small, locally owned businesses.

\begin{tabular}{|c|c|c|c|c|c|}
\hline $\begin{array}{l}\text { Strongly } \\
\text { Disagree }\end{array}$ & Disagr & $\begin{array}{l}\text { Mildly } \\
\text { Disagre }\end{array}$ & $\begin{array}{l}\text { No } \\
\text { Sur }\end{array}$ & Milc & $\begin{array}{l}\text { Strongly } \\
\text { Agree }\end{array}$ \\
\hline
\end{tabular}

19. Access to food is a basic human right.

$\begin{array}{lllllll}\text { Strongly } & \text { Disagree } & \text { Mildly } & \text { Not } & \text { Mildly } & \text { Agree } & \begin{array}{l}\text { Strongly } \\ \text { Disagree }\end{array} \\ & & \text { Disagree } & \text { Sure } & \text { Agree } & & \text { Agree }\end{array}$

20. The current food system does a good job of maintaining biological diversity.

$\begin{array}{lllllll}\text { Strongly } & \text { Disagree } & \text { Mildly } & \text { Not } & \text { Mildly } & \text { Agree } & \text { Strongly } \\ \text { Disagree } & & \text { Disagree } & \text { Sure } & \text { Agree } & & \text { Agree }\end{array}$

21. The current food system does a good job of maintaining cultural traditions and heritage.

Strongly Disagree $\quad$ Mildly $\quad$ Not $\quad$ Mildly Agree Strongly Disagree Disagree Sure Agree Agree

22. Our government should ensure that all people get enough to eat.

$\begin{array}{lllllll}\text { Strongly } & \text { Disagree } & \begin{array}{l}\text { Mildly } \\ \text { Disagree }\end{array} & \begin{array}{l}\text { Not } \\ \text { Sure }\end{array} & \begin{array}{l}\text { Mildly } \\ \text { Agree }\end{array} & \text { Agree } & \begin{array}{l}\text { Strongly } \\ \text { Agree }\end{array}\end{array}$

23. In general, food prices reflect full production and distribution costs, including impacts to environmental and human health.

$\begin{array}{lllllll}\begin{array}{l}\text { Strongly } \\ \text { Disagree }\end{array} & \text { Disagree } & \begin{array}{l}\text { Mildly } \\ \text { Disagree }\end{array} & \begin{array}{l}\text { Not } \\ \text { Sure }\end{array} & \begin{array}{l}\text { Mildly } \\ \text { Agree }\end{array} & \text { Agree } & \begin{array}{l}\text { Strongly } \\ \text { Agree }\end{array}\end{array}$

24. Food labels should say where the food was grown.

$\begin{array}{lllllll}\text { Strongly } & \text { Disagree } & \text { Mildly } & \text { Not } & \text { Mildly } & \text { Agree } & \begin{array}{l}\text { Strongly } \\ \text { Disagree }\end{array} \\ & & \text { Disagree } & \text { Sure } & \text { Agree } & & \text { Agree }\end{array}$

25. Genetically engineered (genetically modified) foods should be labeled.

$\begin{array}{lllllll}\text { Strongly } & \text { Disagree } & \text { Mildly } & \text { Not } & \text { Mildly } & \text { Agree } & \text { Strongly } \\ \text { Disagree } & & \text { Disagree } & \text { Sure } & \text { Agree } & & \text { Agree }\end{array}$


26. Genetically engineered (genetically modified) foods should not be allowed.

$\begin{array}{lllllll}\text { Strongly } & \text { Disagree } & \text { Mildly } & \text { Not } & \text { Mildly } & \text { Agree } & \text { Strongly } \\ \text { Disagree } & & \text { Disagree } & \text { Sure } & \text { Agree } & & \text { Agree }\end{array}$

27. Most farmworkers are paid a living wage.

$\begin{array}{lllllll}\text { Strongly } & \text { Disagree } & \text { Mildly } & \text { Not } & \text { Mildly } & \text { Agree } & \text { Strongly } \\ \text { Disagree } & & \text { Disagree } & \text { Sure } & \text { Agree } & & \text { Agree }\end{array}$

28. Most farmworkers have decent living conditions.

$\begin{array}{lllllll}\text { Strongly } & \text { Disagree } & \text { Mildly } & \text { Not } & \text { Mildly } & \text { Agree } & \text { Strongly } \\ \text { Disagree } & & \text { Disagree } & \text { Sure } & \text { Agree } & & \text { Agree }\end{array}$

29. Our current school food programs are healthy for students.

$\begin{array}{lllllll}\text { Strongly } & \text { Disagree } & \text { Mildly } & \text { Not } & \text { Mildly } & \text { Agree } & \text { Strongly } \\ \text { Disagree } & & \text { Disagree } & \text { Sure } & \text { Agree } & & \text { Agree }\end{array}$

30. Our current school food programs support local environmental and economic health

$\begin{array}{lllllll}\begin{array}{l}\text { Strongly } \\ \text { Disagree }\end{array} & \text { Disagree } & \begin{array}{l}\text { Mildly } \\ \text { Disagree }\end{array} & \begin{array}{l}\text { Not } \\ \text { Sure }\end{array} & \begin{array}{l}\text { Mildly } \\ \text { Agree }\end{array} & \text { Agree } & \begin{array}{l}\text { Strongly } \\ \text { Agree }\end{array}\end{array}$

31. We are too dependent on non-local sources of food.

\begin{tabular}{|c|c|c|c|c|c|}
\hline $\begin{array}{l}\text { Strongly } \\
\text { Disagree }\end{array}$ & Disagree & $\begin{array}{l}\text { Mildly } \\
\text { Disagree }\end{array}$ & $\begin{array}{l}\text { Not } \\
\text { Sure }\end{array}$ & $\begin{array}{l}\text { Mildly } \\
\text { Agree }\end{array}$ & Agree \\
\hline
\end{tabular}

32. We have a duty to future generations to leave the earth in as good or better shape than we found it.

$\begin{array}{lllllll}\text { Strongly } & \text { Disagree } & \text { Mildly } & \text { Not } & \text { Mildly } & \text { Agree } & \begin{array}{l}\text { Strongly } \\ \text { Disagree }\end{array} \\ & & \text { Disagree } & \text { Sure } & \text { Agree } & & \text { Agree }\end{array}$

33. In the long run, we can't have a healthy economy without a healthy environment.

$\begin{array}{lllllll}\text { Strongly } & \text { Disagree } & \text { Mildly } & \text { Not } & \text { Mildly } & \text { Agree } & \text { Strongly } \\ \text { Disagree } & & \text { Disagree } & \text { Sure } & \text { Agree } & & \text { Agree }\end{array}$


34. It would be risky or dangerous to be dependent on non-local, imported food.

\begin{tabular}{|c|c|c|c|c|}
\hline $\begin{array}{l}\text { Strongly } \\
\text { Disagree }\end{array}$ & Disagree & $\begin{array}{l}\text { Mildly } \\
\text { Disagree }\end{array}$ & $\begin{array}{l}\text { Not } \\
\text { Sure }\end{array}$ & $\begin{array}{l}\text { Mildly } \\
\text { Agree }\end{array}$ \\
\hline
\end{tabular}

35. The price of food should reflect its real costs to the environment and human health.

$\begin{array}{lllllll}\text { Strongly } & \text { Disagree } & \text { Mildly } & \text { Not } & \text { Mildly } & \text { Agree } & \begin{array}{l}\text { Strongly } \\ \text { Disagree }\end{array} \\ & & \text { Disagree } & \text { Sure } & \text { Agree } & & \text { Agree }\end{array}$

36. Our government should ensure that businesses are environmentally friendly.

$\begin{array}{lllllll}\text { Strongly } & \text { Disagree } & \text { Mildly } & \text { Not } & \text { Mildly } & \text { Agree } & \text { Strongly } \\ \text { Disagree } & & \text { Disagree } & \text { Sure } & \text { Agree } & & \text { Agree }\end{array}$

37. Our government should ensure that businesses pay a living wage.

\begin{tabular}{|c|c|c|c|c|}
\hline $\begin{array}{l}\text { Strongly } \\
\text { Disagree }\end{array}$ & Disagree & $\begin{array}{l}\text { Mildly } \\
\text { Disagree }\end{array}$ & $\begin{array}{l}\text { Not } \\
\text { Sure }\end{array}$ & $\begin{array}{l}\text { Mildly } \\
\text { Agree }\end{array}$ \\
\hline
\end{tabular}

38. It's okay to put restrictions on trade in order to protect human, environmental, or community health.

$\begin{array}{lllllll}\text { Strongly } & \text { Disagree } & \text { Mildly } & \text { Not } & \text { Mildly } & \text { Agree } & \text { Strongly } \\ \text { Disagree } & & \text { Disagree } & \text { Sure } & \text { Agree } & & \text { Agree }\end{array}$

39. There should be a vision and strategy to ensure that we have a sustainable food system in our region.

$\begin{array}{lllllll}\text { Strongly } & \text { Disagree } & \text { Mildly } & \text { Not } & \text { Mildly } & \text { Agree } & \begin{array}{l}\text { Strongly } \\ \text { Disagree }\end{array} \\ & & \text { Disagree } & \text { Sure } & \text { Agree } & & \text { Agree }\end{array}$

40. I want to learn more about how food systems - from field to fork - affect economic, environmental, and human health in our community.

$\begin{array}{lllllll}\text { Strongly } & \text { Disagree } & \text { Mildly } & \text { Not } & \text { Mildly } & \text { Agree } & \begin{array}{l}\text { Strongly } \\ \text { Disagree }\end{array} \\ & & \text { Disagree } & \text { Sure } & \text { Agree } & & \text { Agree }\end{array}$


41. Please rank how important EACH of the following is to you when making your food purchase decisions.

\begin{tabular}{|c|c|c|c|c|}
\hline & $\begin{array}{l}\text { Not } \\
\text { A } \\
\text { Consideration }\end{array}$ & $\begin{array}{l}\text { A Little Bit } \\
\text { Important } \\
\text { Consideration }\end{array}$ & $\begin{array}{l}\text { Fairly } \\
\text { Important } \\
\text { Consideration }\end{array}$ & $\begin{array}{l}\text { Extremely } \\
\text { Important } \\
\text { Consideration }\end{array}$ \\
\hline Amount of Packaging & & & & \\
\hline Appearance of Product & & & & \\
\hline $\begin{array}{l}\text { Atmosphere of } \\
\text { Shop/Market }\end{array}$ & & & & \\
\hline $\begin{array}{l}\text { Convenience of } \\
\text { Shopping Location }\end{array}$ & & & & \\
\hline Freshness of Product & & & & \\
\hline Healthfulness of Product & & & & \\
\hline $\begin{array}{l}\text { No Genetically } \\
\text { Engineered Ingredients }\end{array}$ & & & & \\
\hline Novelty of Item & & & & \\
\hline $\begin{array}{l}\text { Organic/Sustainable } \\
\text { Farming Methods }\end{array}$ & & & & \\
\hline Price & & & & \\
\hline $\begin{array}{l}\text { Product is Locally } \\
\text { Grown }\end{array}$ & & & & \\
\hline Shop is Locally Owned & . & & & \\
\hline Taste & & & & \\
\hline Value & & & & \\
\hline $\begin{array}{l}\text { Wages and Working } \\
\text { Conditions for Workers }\end{array}$ & & & & \\
\hline $\begin{array}{l}\text { Other (Please list all that } \\
\text { apply) }\end{array}$ & & & & \\
\hline
\end{tabular}

42. What percent of your meals are home cooked? Please CIRCLE ONE.

$$
\text { None } 1 \% \text { to } 10 \% \quad 11 \% \text { to } 25 \% \quad 26 \% \text { to } 50 \% \quad 51 \% \text { to } 80 \% \quad 81 \% \text { to } 100 \%
$$


43. Please note what percent of your at home food groceries come from EACH of the following sources in a typical year.

None $\mathbf{1} \%$ to $\mathbf{1 1} \%$ to $\mathbf{2 6 \%}$ to $\mathbf{5 1 \%}$ to $\mathbf{8 1 \%}$ to
\begin{tabular}{|l|l|l|l|l|l|l|l|}
\hline Your Home Garden & & & & & & \\
\hline Someone Else's Home Garden & & & & & & \\
\hline Farm Stands/U-Pick & & & & & & \\
\hline Farmers' Market & & & & & & \\
\hline Co-op e.g., Food Front, People's & & & & & & \\
\hline $\begin{array}{l}\text { Discount Food Outlet } \text { e.g., Wonder, Sue Bee's, } \\
\text { Franz }\end{array}$ & & & & & & \\
\hline $\begin{array}{l}\text { Natural Food Market e.g., New Seasons, } \\
\text { Nature's }\end{array}$ & & & & & & \\
\hline Specialty Store e.g., Trader Joe's, Zupans & & & & & & \\
\hline Convenience Store e.g., Plaid Pantry, 7-11 & & & & & & \\
\hline Supermarket e.g., Safeway, QFC, Thriftway & & & & & & \\
\hline Superstore e.g., Fred Meyer, Costco & & & & & & \\
\hline Community Supported Agriculture & & & & & & \\
\hline Food Bank, Food Pantry & & & & & & \\
\hline Gleaning & & & & & & \\
\hline Other please specify & & & & & & \\
\hline
\end{tabular}

44. Have you ever been a member of a CSA (Community Supported Agriculture)? (Check One)
No-I am not sure what a CSA is
$\square \quad$ No - But I am considering joining a CSA
$\square \quad$ No - I do not plan to join a CSA
$\square$ Yes

44b. If you answered yes to the above question, do you plan to join a CSA again in the future?
$\square \quad$ Yes - I plan to join a CSA again
$\square$ No-I do not plan to join a CSA again
$\square$ Not sure if I will join a CSA again

45. Do you compost your food waste? (Check One)
$\square$ Yes - Most of the time
$\square$ Yes - A little bit
$\square$ No-But I plan to
$\square$ No

46. In your opinion, what are the key factors positively shaping the viability of community food systems in the Portland metropolitan region? Feel free to add additional pages if necessary, noting the number of the question. 
47. In your opinion, what are the key factors negatively shaping the viability of community food systems in the Portland metropolitan region? Feel free to add additional pages if necessary, noting the number of the question.

48. What measures, if any, have you taken to support community food systems in the Portland metropolitan region? Feel free to add additional pages if necessary, noting the number of the question.

49. What additional information or skills, if any, would help you feel better able to address community food system issues? Feel free to add additional pages if necessary, noting the number of the question.

Recall that the entire survey will remain confidential. The following information will be useful for determining if there are significant differences in the types of responses between different groups of people (for example, women and men, different ages). You may choose to not answer specific questions.

50. Your Age (Circle One)

$\begin{array}{lllllll}\text { Less than } 20 \text { Years } & 20 \text { to } 30 \quad 31 \text { to } 40 \quad 41 \text { to } 50 \quad 51 \text { to } 60 & 61 \text { to } 70 & 71+\end{array}$

51. Your Gender (Circle One)

Male Female

52. Length of residency in Oregon years

53. Zip code of residence 
54. Number of persons in your household (related and unrelated adults \& children sharing food \& finances in the home)

55. Approximately how much of the household food shopping do you do?
None
$1 \%$ to $25 \%$
$26 \%$ to $50 \%$
$51 \%$ to $75 \%$
$76 \%$ to $100 \%$

56. Annual Household Income - Combined Income of Household Members (Check One)
$\square \quad$ Less than $\$ 10,000$
$\square \$ 10,000$ to $\$ 30,000$
$\square \$ 30,001$ to $\$ 50,000$
$\square \quad \$ 50,001$ to $\$ 70,000$
$\square \quad \$ 70,001$ to $\$ 90,000$
$\square \$ 90,001$ to $\$ 110,000$
$\square$ Greater than $\$ 110,000$

57. Highest level of education completed (Select One)
$\square \quad$ No High School
$\square \quad$ Some High School
$\square \quad$ High School Graduate/GED
$\square \quad$ Some College
$\square \quad$ Two Year College Degree
$\square \quad$ Four Year College Degree
$\square \quad$ Some Graduate Work
$\square \quad$ Master's Degree
$\square \quad$ Some Doctoral Work
$\square \quad$ Ph.D. 
58. Ethnicity (Check all that apply)

․ African-American

$\square \quad$ Asian/Southeast Asian

$\square \quad$ Hispanic - White

$\square \quad$ Hispanic - Non-white

$\square \quad$ Native American

$\square \quad$ White

$\square \quad$ Other (please specify)

59. If there is anything else you would like to share regarding the topic of sustainable community food systems please feel free to do so below or on another page.

Thank you for taking the time to complete this survey. Please return the survey in the enclosed stamped, addressed envelope to:

Janet Hammer

Portland State University

PO Box 751-USP

Portland, OR 97202-0751 


\section{APPENDIX K: INTERVIEW PROTOCOL}

The following is the base script for the semi-structured interview.

More and more, folks are realizing that we need to work collaboratively and systemically to address community food system issues. But we are still figuring out the best ways to do that. This interview focuses on your experience in Community Food Matters so that we can learn more about the topic of collaborative food system projects.

I would like to remind you that all answers are confidential - no comment will be attributed to a specific person or organization. Also, you may decline to answer any questions that you do not want to answer.

I also want to remind you that there are no right or wrong answers: The purpose of this interview is simply to learn more about people's experience with this process so we can better understand the value of such collaborations for participants and the community.

Finally, I want to be clear that you should feel free to say things that critique the process in general, or me in particular. We are trying to learn how best to do collaborative food system work so you should feel free to speak whatever comes to mind. If there is something you don't feel comfortable saying, I am leaving this blank paper and an addressed, stamped envelope so that you can anonymously submit your comments. Are there any questions I can answer for you? Shall we begin?

If someone were to ask you "what is Community Food Matters?" what would you say?

If Community Food Matters is successful what will be different? 
Imagine that someone said that they were thinking to do some sort of similar collaborative learning and action initiative around food system issues in their community - what advice would you give them?

How about the Forum? Can you share your thoughts on that event?

In your opinion, what aspects of Community Food Matters are working well?

What aspects of Community Food Matters could be improved and how?

What has it meant to you to participate in Community Food Matters?

If someone were to ask you "what is a sustainable community food system?" what would you say?

Would you say that any of your beliefs or values about the food system have changed since you began participating in Community Food Matters?

How so?

In what ways, if any, have there been changes in your work or in your personal life that are related to your participation in Community Food Matters?

One goal of collaborative learning and action groups such as CFM is improved understanding of issues. In what ways if any do you think CFM is achieving that goal? 
Another goal of collaborative learning and action groups such as CFM is improved partnerships - either new or existing. In what ways, if any, do you think CFM is achieving that goal?

Often collaborative learning and action initiatives such as CFM are designed to be participatory, fair, and democratic. How well do you feel CFM is achieving those goals? Have you felt at all that it hasn't been participatory, fair, or democratic? Have there been any power imbalances?

Sometimes collaborative efforts can involve issues of trust. Do you recall having any trust issues surrounding the project and, if so, how, if at all, were the issues resolved?

Sometimes collaborative efforts can bring up difficult emotions. Do recall feeling any such emotions associated with your participation and if so, what came up and how, if at all, were the issues resolved?

We're at the end. I want to come back to the question of the value and impact of collaborative learning and action around community food issues - do you have any final thoughts on this subject? 


\section{APPENDIX L: SCHOOL FOOD FORUM AGENDA}

Nourishing Kids and Communities: An Action Summit on Schools and Food

8:00 to 8:30 Registration

8:30 to 9:30 Welcome and Visions of Schools and Food

Vignettes of potential futures and group discussion of where we want to be.

9:30 to 11:00 Existing Context

Panel and group discussion about current programs and possibilities - where we are.

Panelists include:

Joyce Dougherty, Oregon Department of Education

Shannon Stember, Portland Public Schools Food Service

Arianne Newton, Trillium School

Sarah Taylor, Sunnyside School

Linda Colwell, Edwards Elementary

Laura Masterson, The $47^{\text {th }}$ Avenue Farm

Michelle Markesteyn, Portland State University/Tufts University

Tim Swinehart, Portland Area Rethinking Schools - Franklin High and student Wisteria Loeffler, Zenger Farm

11:00 to 11:30 Break

Light refreshment served.

11:30 to 12:40 Moving Forward

Stakeholder groups meet to identify abilities and constraints for moving forward, followed by group discussion.

12:40 to 1:00 Next Steps and Closing 


\section{APPENDIX M: REGIONAL FOOD ASSESSMENT FORUM EVALUATION}

\section{Input on Regional Food System Assessment}

Imagine that you have a "go to" place where you can find an array of information about food system issues. Imagine a State of the Region's Food System report that includes information on economic, environmental and social dimensions of the food system. Indicators may address such things as food access, farm viability, diet related health outcomes, food based economic development, and environmental stewardship in food production and distribution. The assessment could help identify gaps and opportunities and be used by governmental, nongovernmental, and private sector organizations to develop programs and policies that promote a more sustainable food system in this region. As we contemplate undertaking a food system assessment it would be helpful to hear from you.

A State of the Region's Food System assessment in this region would be (circle one):

VERY USEFUL

NOT SURE

NOT SO NOT USEFUL USERUL USEFUL USEFUL AT ALL

If an assessment were conducted, information that could be helpful to me or my organization includes: 


\section{Community Food Matters Listserv}

1] Please add me to the Community Food Matters listserv. This relatively low volume list provides information about news and events related to our mission of improving economic, environmental, and human health in rural and urban communities through the development of sustainable food systems.

My name is

My organization is

My email is

My phone number is

\section{Event Evaluation}

Overall, the afternoon session was (circle one):

Excellent Good Fair Poor

Overall, the afternoon session was (circle one):

Excellent Good Fair Poor

The best things about this event were...

Areas for improvement include... 


\section{APPENDIX N: UNROTATED AND ROTATED COMPONENT MATRICES}

\section{Pre-Survey Unrotated Component Matrix}

\begin{tabular}{|c|c|c|c|c|}
\hline 1 & .693 & .584 & .229 & -.297 \\
\hline 2 & .967 & $-7.380 \mathrm{E}-02$ & $-4.221 \mathrm{E}-02$ & -.104 \\
\hline 3 & .935 & .127 & $2.558 \mathrm{E}-02$ & -.234 \\
\hline 4 & 893 & .198 & $2.623 \mathrm{E}-02$ & .103 \\
\hline 5 & .924 & $-1.206 \mathrm{E}-02$ & $-1.024 \mathrm{E}-02$ & .242 \\
\hline 6 & .640 & .512 & -.139 & .466 \\
\hline 7 & .962 & -.145 & .124 & $5.384 \mathrm{E}-02$ \\
\hline 8 & .862 & $3.050 \mathrm{E}-02$ & -.296 & $3.140 \mathrm{E}-02$ \\
\hline 9 & .925 & .230 & $-2.251 \mathrm{E}-02$ & $-9.657 \mathrm{E}-02$ \\
\hline 10 & .971 & $2.190 \mathrm{E}-02$ & -.134 & $-3.707 \mathrm{E}-02$ \\
\hline 11 & .848 & -.163 & $-5.099 \mathrm{E}-02$ & .155 \\
\hline 12 & .959 & $5.738 \mathrm{E}-02$ & $2.587 \mathrm{E}-02$ & $-4.877 \mathrm{E}-02$ \\
\hline 13 & .933 & .102 & $-3.035 \mathrm{E}-02$ & -.159 \\
\hline 14 & .960 & $8.924 \mathrm{E}-02$ & -.123 & $-5.683 \mathrm{E}-02$ \\
\hline 15 & .825 & $2.017 \mathrm{E}-02$ & -.110 & -.165 \\
\hline 16 & .943 & $6.112 \mathrm{E}-02$ & -.258 & $-5.166 \mathrm{E}-03$ \\
\hline 17 & .643 & $3.794 \mathrm{E}-02$ & .608 & -.318 \\
\hline 18 & .878 & $-6.352 \mathrm{E}-02$ & .242 & $7.822 \mathrm{E}-02$ \\
\hline 19 & .797 & -.167 & -.126 & -.176 \\
\hline 20 & .756 & .541 & -.163 & .141 \\
\hline 21 & .837 & $-1.493 \mathrm{E}-02$ & $5.071 \mathrm{E}-02$ & -.138 \\
\hline 22 & .899 & $-3.864 \mathrm{E}-02$ & $-7.615 \mathrm{E}-02$ & $-5.320 \mathrm{E}-02$ \\
\hline 23 & .966 & -.139 & -.108 & $-7.670 \mathrm{E}-02$ \\
\hline 24 & .971 & $-7.745 \mathrm{E}-03$ & -.108 & $-2.909 \mathrm{E}-02$ \\
\hline 25 & .963 & $-2.069 \mathrm{E}-02$ & -.111 & $-3.063 \mathrm{E}-02$ \\
\hline 26 & .954 & $-9.869 \mathrm{E}-02$ & -.137 & $-2.189 \mathrm{E}-02$ \\
\hline 27 & .923 & -.204 & .187 & .136 \\
\hline 28 & .821 & $-8.022 \mathrm{E}-02$ & -.330 & $-9.710 \mathrm{E}-02$ \\
\hline 29 & .981 & -.120 & $3.427 \mathrm{E}-02$ & $3.377 \mathrm{E}-02$ \\
\hline 30 & .980 & -.108 & $4.094 \mathrm{E}-02$ & $-5.220 \mathrm{E}-02$ \\
\hline 31 & .902 & -.300 & .152 & .132 \\
\hline 32 & .979 & $2.210 \mathrm{E}-03$ & $4.703 \mathrm{E}-02$ & $1.579 \mathrm{E}-02$ \\
\hline 33 & .974 & -.113 & .107 & $4.455 \mathrm{E}-02$ \\
\hline 34 & .976 & $4.559 \mathrm{E}-02$ & $-3.461 \mathrm{E}-02$ & $-8.843-03$ \\
\hline 35 & .971 & -.144 & $8.586 \mathrm{E}-02$ & $-3.953 \mathrm{E}-02$ \\
\hline 36 & .957 & -.104 & -.153 & $-1.546 \mathrm{E}-02$ \\
\hline 37 & .645 & .561 & .364 & $7.054 \mathrm{E}-02$ \\
\hline 38 & .948 & $1.299 \mathrm{E}-03$ & .154 & $6.382 \mathrm{E}-02$ \\
\hline 39 & .973 & $3.404 \mathrm{E}-03$ & -.150 & -.151 \\
\hline 40 & .962 & -.130 & $3.979 \mathrm{E}-02$ & $-1.358 \mathrm{E}-02$ \\
\hline 41 & .943 & -.214 & .130 & $1.252 \mathrm{E}-02$ \\
\hline 42 & .955 & $-3.153 \mathrm{E}-02$ & .199 & $1.389 \mathrm{E}-02$ \\
\hline 43 & .839 & .389 & -.121 & $7.443 E-03$ \\
\hline 44 & .926 & -.222 & .131 & .204 \\
\hline 45 & .970 & $-8.973 \mathrm{E}-02$ & -.107 & $-6.874 \mathrm{E}-03$ \\
\hline 46 & .862 & -.342 & .128 & .248 \\
\hline 47 & .986 & $6.773 \mathrm{E}-03$ & $-6.216 \mathrm{E}-02$ & $-2.356 \mathrm{E}-02$ \\
\hline 48 & .937 & $-3.430 \mathrm{E}-02$ & $-6.206 \mathrm{E}-02$ & -.100 \\
\hline 49 & .884 & .168 & .173 & .342 \\
\hline
\end{tabular}


Pre-Survey Rotated Component Matrix

\begin{tabular}{|c|c|c|c|c|}
\hline 1 & .382 & $5.669 \mathrm{E}-02$ & .519 & .737 \\
\hline 2 & .696 & .563 & .256 & .296 \\
\hline 3 & .675 & .403 & .320 & .476 \\
\hline 4 & .487 & .486 & .535 & .296 \\
\hline 5 & .485 & .667 & .464 & .129 \\
\hline 6 & .234 & .259 & .887 & $1.048 \mathrm{E}-02$ \\
\hline 7 & .524 & .731 & .264 & .292 \\
\hline 8 & .714 & .405 & .395 & $5.049 \mathrm{E}-02$ \\
\hline 9 & .625 & .382 & .472 & .398 \\
\hline 10 & .716 & .507 & .375 & .229 \\
\hline 11 & .515 & .650 & .280 & $7.474 \mathrm{E}-02$ \\
\hline 12 & .611 & .536 & .373 & .354 \\
\hline 13 & .676 & .427 & .346 & .386 \\
\hline 14 & .704 & .460 & .411 & .269 \\
\hline 15 & .666 & .373 & .250 & .275 \\
\hline 16 & .756 & .436 & .425 & .132 \\
\hline 17 & .176 & .459 & $3.323 \mathrm{E}-02$ & .801 \\
\hline 18 & .380 & .692 & .294 & .362 \\
\hline 19 & .680 & .448 & $9.374 \mathrm{E}-02$ & .196 \\
\hline 20 & .468 & 161 & .785 & .224 \\
\hline 21 & .566 & .473 & .224 & .359 \\
\hline 22 & .646 & .512 & .287 & .235 \\
\hline 23 & .729 & .585 & .228 & .213 \\
\hline 24 & .698 & .537 & .354 & .232 \\
\hline 25 & .697 & .538 & .341 & .225 \\
\hline 26 & .710 & .568 & .286 & .171 \\
\hline 27 & .429 & .800 & .241 & .256 \\
\hline 28 & .777 & .371 & .233 & $4.945 \mathrm{E}-02$ \\
\hline 29 & .599 & .686 & .290 & .257 \\
\hline 30 & .632 & .643 & .253 & .315 \\
\hline 31 & .448 & .825 & .162 & .195 \\
\hline 32 & .586 & .615 & .370 & .318 \\
\hline 33 & .544 & .710 & .290 & .300 \\
\hline 34 & .642 & .548 & .399 & .291 \\
\hline 35 & .596 & .681 & .224 & .323 \\
\hline 36 & .720 & .569 & .289 & .156 \\
\hline 37 & .103 & .253 & .662 & .597 \\
\hline 38 & .479 & .659 & .371 & .354 \\
\hline 39 & .780 & .463 & .304 & .278 \\
\hline 40 & .606 & .661 & .250 & .279 \\
\hline 41 & .534 & .741 & .182 & .290 \\
\hline 42 & .482 & .676 & .318 & .404 \\
\hline 43 & .569 & .252 & .626 & .302 \\
\hline 44 & .436 & .820 & .271 & .174 \\
\hline 45 & .695 & .591 & .303 & .191 \\
\hline 46 & .389 & .865 & .179 & $8.572 \mathrm{E}-02$ \\
\hline 47 & .676 & .558 & .368 & .270 \\
\hline 48 & .684 & .517 & .279 & .285 \\
\hline 49 & .285 & .658 & .617 & .246 \\
\hline
\end{tabular}


Post-Survey Unrotated Component Matrix

\begin{tabular}{|c|c|c|c|}
\hline 1 & .307 & .670 & .505 \\
\hline 2 & .976 & $3.685 \mathrm{E}-02$ & $3.064 \mathrm{E}-02$ \\
\hline 3 & .944 & .107 & $4.266 \mathrm{E}-02$ \\
\hline 4 & .979 & $5.972 \mathrm{E}-02$ & $-2.099 \mathrm{E}-02$ \\
\hline 5 & .917 & .154 & .251 \\
\hline 6 & .639 & .379 & -.322 \\
\hline 7 & .969 & $-4.331 \mathrm{E}-02$ & .115 \\
\hline 8 & .934 & .120 & $-8.774 \mathrm{E}-02$ \\
\hline 9 & .961 & .137 & $-1.003 \mathrm{E}-02$ \\
\hline 10 & .985 & -.108 & $2.216 \mathrm{E}-02$ \\
\hline 11 & .897 & $-9.903 \mathrm{E}-02$ & .140 \\
\hline 12 & .965 & $3.020 \mathrm{E}-02$ & $-1.774 \mathrm{E}-02$ \\
\hline 13 & .712 & .397 & -.314 \\
\hline 14 & .993 & $-2.629 \mathrm{E}-02$ & $-5.545 \mathrm{E}-02$ \\
\hline 15 & .926 & $3.970 \mathrm{E}-02$ & -.125 \\
\hline 16 & .984 & $2.525 \mathrm{E}-02$ & $-2.403 \mathrm{E}-02$ \\
\hline 17 & .842 & -.131 & $8.609 \mathrm{E}-02$ \\
\hline 18 & .896 & -.107 & .112 \\
\hline 19 & .975 & $-1.427 \mathrm{E}-02$ & $-2.050 \mathrm{E}-02$ \\
\hline 20 & .736 & .317 & -.503 \\
\hline 21 & .950 & $9.120 \mathrm{E}-02$ & $-3.518 \mathrm{E}-02$ \\
\hline 22 & .956 & .152 & $-1.439 \mathrm{E}-02$ \\
\hline 23 & .976 & -.141 & $-4.132 \mathrm{E}-02$ \\
\hline 24 & .933 & $-7.865 \mathrm{E}-02$ & $8.746 \mathrm{E}-02$ \\
\hline 25 & .982 & -.138 & 5.920E-03 \\
\hline 26 & .980 & -.123 & $-2.048 \mathrm{E}-02$ \\
\hline 27 & .932 & -.181 & $-4.858 E-02$ \\
\hline 28 & .950 & -.129 & $-8.283 \mathrm{E}-02$ \\
\hline 29 & .960 & -.154 & $6.416 \mathrm{E}-02$ \\
\hline 30 & .978 & -.146 & 5.402E-02 \\
\hline 31 & .983 & -.103 & $-3.556 \mathrm{E}-02$ \\
\hline 32 & .847 & $-7.857 \mathrm{E}-02$ & -.298 \\
\hline 33 & .957 & -.105 & .118 \\
\hline 34 & .975 & -.124 & $2.181 \mathrm{E}-02$ \\
\hline 35 & .922 & $-8.498 \mathrm{E}-02$ & $9.185 \mathrm{E}-02$ \\
\hline 36 & .959 & $4.905 \mathrm{E}-02$ & $-2.297 \mathrm{E}-02$ \\
\hline 37 & .370 & .818 & .140 \\
\hline 38 & .974 & -.141 & $2.120 \mathrm{E}-03$ \\
\hline 39 & .968 & $-8.112 E-02$ & $7.260 \mathrm{E}-02$ \\
\hline 40 & .881 & $-8.943 E-02$ & .283 \\
\hline 41 & .976 & -.174 & $2.892 \mathrm{E}-02$ \\
\hline 42 & .985 & $1.185 \mathrm{E}-02$ & $-9.911 \mathrm{E}-02$ \\
\hline 43 & .665 & .488 & $8.209 \mathrm{E}-02$ \\
\hline 44 & .981 &,- 128 & $3.103 \mathrm{E}-02$ \\
\hline 45 & .981 & -.151 & $2.570 \mathrm{E}-02$ \\
\hline 46 & .953 & -.143 & $7.525 \mathrm{E}-02$ \\
\hline 47 & .915 & .112 & $-9.533 \mathrm{E}-02$ \\
\hline 48 & .955 & .103 & $-5.689 \mathrm{E}-02$ \\
\hline 49 & .959 & .122 & $3.082 \mathrm{E}-02$ \\
\hline
\end{tabular}


Post-Survey Rotated Component Matrix

\begin{tabular}{|c|c|c|c|}
\hline 1 & .114 & $1.120 \mathrm{E}-02$ & .886 \\
\hline 2 & .843 & .415 & .270 \\
\hline 3 & .788 & .421 & .325 \\
\hline 4 & .822 & .467 & .261 \\
\hline 5 & .798 & .262 & .471 \\
\hline 6 & .316 & .693 & .275 \\
\hline 7 & .892 & .311 & .250 \\
\hline 8 & .741 & .525 & .262 \\
\hline 9 & .777 & .483 & .325 \\
\hline 10 & .909 & .364 & .150 \\
\hline 11 & .859 & .236 & .202 \\
\hline 12 & .824 & .446 & .235 \\
\hline 13 & .374 & .726 & 311 \\
\hline 14 & .862 & .464 & .176 \\
\hline 15 & .758 & .518 & .175 \\
\hline 16 & .841 & .457 & .232 \\
\hline 17 & .810 & .242 & .135 \\
\hline 18 & .854 & .255 & .180 \\
\hline 19 & .850 & .433 & .200 \\
\hline 20 & .380 & .853 & .148 \\
\hline 21 & .780 & .479 & .271 \\
\hline 22 & .765 & .490 & .334 \\
\hline 23 & .899 & .398 & $8.733 \mathrm{E}-02$ \\
\hline 24 & .868 & .302 & .198 \\
\hline 25 & .915 & .364 & .117 \\
\hline 26 & .900 & .390 & .114 \\
\hline 27 & .876 & .368 & $4.133 \mathrm{E}-02$ \\
\hline 28 & .861 & .424 & $6.833 \mathrm{E}-02$ \\
\hline 29 & .918 & .301 & .131 \\
\hline 30 & .928 & .320 & .136 \\
\hline 31 & .890 & .412 & .123 \\
\hline 32 & .695 & .572 & $-3.249 \mathrm{E}-02$ \\
\hline 33 & .908 & .277 & .199 \\
\hline 34 & .907 & .354 & .135 \\
\hline 35 & .863 & .292 & .193 \\
\hline 36 &, 809 & .455 & .246 \\
\hline 37 & $1.451 \mathrm{E}-02$ & .392 & .820 \\
\hline 38 & .909 & .362 & .110 \\
\hline 39 & .896 & .328 & .196 \\
\hline 40 & .877 & .119 & .285 \\
\hline 41 & .931 & .328 & $9.929 \mathrm{E}-02$ \\
\hline 42 & .828 & .512 & .181 \\
\hline 43 & .395 & .428 & .590 \\
\hline 44 & .916 & .347 & .139 \\
\hline 45 & .925 & .342 & .117 \\
\hline 46 & .910 & .294 & .144 \\
\hline 47 & .726 & .520 & .248 \\
\hline 48 & .774 & .503 & .270 \\
\hline 49 & .792 & .443 & .335 \\
\hline
\end{tabular}




\section{APPENDIX O: FORUM ORIENTATION LETTER}

March 27, 2002

Greetings to our valued participants in the upcoming event Growing a Regional Food Economy: A Forum for Promoting Good Jobs, Food Access, Environmental Stewardship, and Farm Viability on April 11-12. This packet includes materials that will enhance your experience and provide us with critical information to prepare for the forum. This letter confirms your registration for the event.

Please arrive between 8:30 and 8:45 AM on April $11^{\text {th }}$ to allow time for check-in. The forum begins at 9:00 sharply. The forum will be held in the $2^{\text {nd }}$ floor conference center of the Natural Capital Center, 721 NW Ninth Ave., Portland. We will provide coffee and light refreshments each morning and lunch each afternoon. On the $11^{\text {th }}$, there will be an informal evening reception from 5 to $6: 30$ PM. Because space is limited to 100 and the forum activities are designed to carefully build on each other, we respectfully request that you attend the entire forum.

A detailed agenda will be provided on arrival. As your invitation noted, the forum will include a keynote by Wes Jackson, presentations on the state of the region's food system, and time for peer-to-peer learning and launching new projects. The forum also includes a conversation about how to define and measure a healthy regional food system. Will we know it if we see it? You are encouraged to bring along some indicators that measure the health of our food system. 
You will find the following items in this packet:

- If you requested them, complimentary ticket(s) to Wes Jackson's Institute for the Northwest lecture on April 10 ${ }^{\text {th }}$ at 7:30 PM at the Northwest Neighborhood Cultural Center, 1819 NW Everett St., Portland.

- Directions and transportation information for the forum. Public transportation and carpooling are encouraged.

- A survey on community food systems along with an addressed, stamped envelope. Please return this survey before you attend the forum (post-mark by April 10), or turn it in when you check in at the forum. Evaluation of this effort to improve the region's food system will be very helpful to our community and to other groups working on similar issues.

If you have any questions regarding logistics, please call Kara Orvieto at 503467-0758. If you have any questions about the Community Food Matters initiative, please call Janet Hammer at 503-725-4019.

We are looking forward to seeing you at the forum!

Stuart Cowan

Ecotrust
Janet Hammer

Community Food Matters 


\section{APPENDIX P: CFM DECLARATION}

On this day, April 12th, 20o2, Community Food Matters, a coalition of citizens and organizations concerned about the health of our regional food system, is founded.

Community Food Matters believes that a healthy and secure food system must:

1. Bridge the gap between rural and urban eaters, growers and producers

2. Ensure access to quality food for all citizens

3. Improve stewardship of our natural resources

4. Ensure local control of the region's food system

5. Provide living wages in the food industry and a future for young farmers

6. Enhance our unique sense of place.

We, the undersigned, support this vision for a healthy regional food system, acknowledge that achievement of this vision will only occur if we work together and agree to the collaboration, communication, and commitment required to make this vision a reality.

Signed: 


\title{
APPENDIX Q: SEED TO SUPPER DRAFT CURRICULUM CONCEPT
}

\author{
Seed to Supper - A Sustainable Community Food System Education \\ Program
}

This program creates classroom and community-based experiences that build community capacity to effectively engage as citizens and consumers in the food system. Participants learn about economic, environmental, and cultural dimensions of the food system, improve their personal food security skills, gain an understanding of their place in the food system, and contribute to community food assessment and community food security through service learning projects.

This is an innovative model, transferable to other communities, that improves community food security not only by teaching participants how to grow or prepare food, but by providing a critical understanding of food system issues and the knowledge and skills to participate effectively in shaping a sustainable food system (e.g., as grower, eater, and citizen).

This community-based learning program provides an integrated learning experience that includes classroom and garden curricula, field trips, and neighborhood-based research. The unit can be offered in schools or as an "institute" or camp out of school. This community-based, active learning project includes:

- "seed to supper" curriculum on food system issues - biodiversity, growing food, animals and sea creature in the food system, nutrition and food preparation, composting and soil health, food access issues, food and the economy, food and the environment, food and culture

- field trips to farms, food bank, and other food system sites 
- hands-on garden experience

- participation in community food system assessment tied to research skill building and civic participation (assessment results used in policy making)

- service learning such as installation of gardens in homes of low-income residents

- youth initiated pilot projects to improve personal, school, or community food systems.

The curriculum is targeted to middle school youth but should be able to be scaled up or down. The curriculum will include notation about how to use the units in different settings (e.g., classes that meet daily over a year, classes that meet daily for a brief intensive, classes that meet once or twice a week over a certain time period). Whatever the setting, the same content will be covered (though the activities in the content may vary - e.g., a seed activity in a 2 week course may look different than the activity for a year long course).

A sub-objective is to evaluate the effectiveness of the curriculum in various configurations (e.g., intensive or extensive learning setting as discussed above).

Site selection criteria for the summer institute include: indoor/sheltered teaching space, bathrooms, outdoor garden and tools.

For the institute, the team would like to encourage diverse incomes and geographic home bases to mix but acknowledged the logistical difficulty of making this happen. It was felt that east side and west side folks would likely select the institute most convenient to their home. Thus, in our pilot, if we offer one on the east side and one on the west, enough geographic and income diversity exists within east and west that some good mixing would likely still occur; further, field trips help expose learners to different parts of the region. 
The time frame for the institute would likely be 9 to 4 (in that range). We would probably offer a central drop-off/pick up site (or a few). For example, one at 8:30 and one at $8: 45$, with drop off at $4: 30$ and $4: 45$.

Current Team Members:

Trillium Charter School, Portland Community Gardens, Old McDonald's Farm, Oregon Tilth, Growing Gardens, Friends of Zenger Farm, Oregon Food Bank, Community Food Matters, PSU.

Activities:

- Develop Seed to Supper program building on existing regional and national models

- Deliver Seed to Supper program as summer institute and in-school program (Trillium, possibly 1 other)

- Evaluate and revise program

- Deliver modified Seed to Supper Program

- Evaluate and revise program

- Dissemination (events, print, web).

Budget Estimate - $\$ 150,000$. Budget supports hire of Education Specialist to lead the development and implementation of curriculum (in conjunction with team members), stipend to team members, funds for field trips and incidentals. 


\section{APPENDIX R: DRAFT INDICATORS}

\section{Draft Goals for a Sustainable Food System}

\section{Economic Vitality}

Food production businesses are profitable and the food economy contributes to the economic vitality of the region.

\section{Resource Stewardship}

Natural, animal, and marine resources are well stewarded through the system of food production, processing, distribution and disposal.

\section{Resiliency}

The food system is resilient in the face of threats to food supply or safety.

\section{Opportunity and Justice for Workers}

Farmers, fishers, and food workers earn a living wage, have safe working conditions, and have opportunities for advancement.

\section{Food Access}

Residents have easy access to culturally appropriate, healthy, affordable foods that are regionally and sustainably produced.

\section{Food Choices Support Personal and Community Health}

Residents have the information necessary to make food choices that support economic, environmental, and human health, and the power to participate in food policy decisions. 


\section{Sample Indicators}

This is NOT a complete or comprehensive list; this is for example only.

Note, some measures may be listed under more than one goal. ${ }^{2}$

\section{Economic Vitality}

Food production businesses are profitable and the food economy contributes to the economic vitality of the region.

- Farming receipts and \% of total earnings in region

- Food manufacturers/processors receipts and \% of total earnings in region

- Food wholesalers gross receipts and \% of total earnings in region

- Food retailers gross receipts and \% of total earnings in region

- Food service gross receipts and \% of total earnings in region

- Total food and farm earnings, $\%$ of earnings

- Food and farm cluster earnings and \% of earnings

- Farming \# of jobs and $\%$ of jobs in region

- Farming principal occupation of operators, $\%$ of farms

- Food manufacturers/processors \# of jobs and \% of jobs in region

- Food wholesalers \# of jobs and $\%$ of jobs in region

- Food retailers \# of jobs and \% of jobs in region

- Food service \# of jobs and \% of jobs in region

\footnotetext{
${ }^{2}$ A refined indicator list was developed as part of the regional food system assessment report (Hammer \& Margheim, 2006). 
- Total food and farm employment, \% of jobs in region

- Income/employment from commercial fishing and processing (\#s, changes over time, measure of concentration)

- Farms by size, type

- Net farm income; farm production balance - by size, type

- Farmgate to retail spread

- Zoning supports appropriate on-farm business

- \% of retail food businesses locally owned

- \% of processors locally owned

- Processors by size, type

- $\%$ of retail chains locally owned

- \# of retail chains

- Number of federal and state inspected slaughterhouses

- \# of commercial fishing licenses and permits

- Gross receipts from direct farm marketing, $\%$ of total farm earnings in region

- $\%$ of farms engaged in direct marketing

- Number and \% of counties participating in Buy Local/branding campaign(s)

- Number and \% of producers participating in Buy Local/branding campaign(s)

- Number and \% of stores participating in Buy Local/branding campaign(s)

- Total and per capita food expenditures, as a $\%$ of national average, as $\%$ of total food and farm earnings in region

- Achievement of regional food economy potential (e.g., if $\mathrm{x} \%$ of food dollars are spent on local product, impact to farm income and food cluster businesses). 


\section{Resource Stewardship}

Natural, animal, and marine resources are well stewarded through the system of food production, processing, distribution and disposal.

- Farmland in permanent, deeded protection (acres and \# of farms)

- Acres and farms in ag protection zoning

- \# acres $/ \%$ of prime farmland lost since $x$ date

- average farm size

- $\%$ of acres in full, part, and tenant ownership

- Urban ag lands

- \# of acres in no-take marine reserves

- $\%$ of farm acres with conservation plan

- \% of farm acres organic, food alliance, live, and/or salmon safe certified

- \% of farms organic, food alliance, live, and/or salmon safe certified

- $\%$ of animal farmers with humane certification for production

- $\%$ of beef production grass fed

- $\%$ of poultry "free-range"

- $\%$ of dairy $\mathrm{rBGH}$ free

- Number of crops in the region accounting for $75 \%$ of harvested acres

- Number of cultivars for selected commodities accounting for top $75 \%$ of production

- Seed saving, seed exchanges, something from RAFT 
- Amount of GMO drift/biopollution (\# of cases, \# of acres)

- Sub-therapeutic antibiotic use

- Tons of topsoil lost/year

- Total tons of synthetic pesticides used in agriculture

- Funding for pesticide tracking laws

- $\%$ of commercial pesticide operators complying with the Pesticide Use Reporting System requirements

- Amount of water quality limited surface water with agriculture as a source of pollution

- Well water pollution, average nitrate (no3)

- Total water usage (acre-feet) in agriculture

- Fuel, fertilizer and chemical expense in agriculture as $\%$ of total expenses

- Alternative fuels in production

- $\mathrm{Ag}$ and food waste reduction e.g., store containers, farm delivery containers

- Animal waste recovery - e.g., compost, methane

- Food recovery programs

- Participation rate in food diversion programs

- Reuse, recycle in processing

- $\%$ of food business with Food Alliance, Natural Step, ZWA or other sustainability certification

- $\%$ of food and ag waste composted (farm, residential, commercial, institutional)

- Food miles

- Energy intensity of production 
- Average age farmers, fishers

- Ease of entry to new farmers, fishers; programs to facilitate

- Ease of exit from farming and keeping land in agriculture

- Fisheries threatened. 


\section{Resiliency}

The food system is resilient in the face of threats to food supply or safety.

- Farms by size, type, acres per capita, ownership

- Average age of farmers

- Diversity of crops e.g., crops and livestock produced on $x \%$ of farms

- \% of population growing food - farming and gardening

- Fisheries ownership

- Average age of fishers

- Market/retail ownership (number, concentration)

- Number of manufacturers/processors (by size and ownership)

- Diversity of seed source

- Seed saving networks

- Number of crops in the region accounting for $75 \%$ of harvested acres

- Number of cultivars for selected commodities accounting for top $75 \%$ of production

- Fuel, fertilizer and chemical expense in agriculture as \% of total expenses

- Food Miles

- Roads, bridges, trains and ports diverse, maintained, protected to human and natural disasters

- Haccp - Hazard Analysis and Critical Control Point

- Precautionary principals implemented

- Threats to genetic pollution addressed

- Sustainable agriculture programming/resources. 


\section{Opportunity and Justice for Workers}

Farmers, fishers, and food workers earn a living wage, have safe working conditions, and have opportunities for advancement.

- $\%$ of farms fully owned by farmer

- Net farm income

- $\%$ of farmers, full time

- $\%$ of farmers with health insurance

- Ease of entry to new farmers, fishers; programs to facilitate

- Ease of exit from farming and keeping land in agriculture

- Women and minority ownership in farming (\# and acres)

- Average wage paid to farmworkers (median and mean, compared to other industries)

- Percentage of farmworkers employed through farm labor contractors

- Number of farm workers, \% of farmworkers full time/year round

- Percentage of farmworkers with health insurance

- Average wage paid to food processing workers (median and mean, compared to other industries)

- Percentage of food processing workers with health insurance

- Average wage paid to grocery workers ((median and mean, compared to other industries)

- $\%$ of grocery workers with health benefits 
- Average wage paid to food service workers (median and mean, compared to other industries)

- $\%$ of food service workers with health benefits

- Avg age fishers

- \# of commercial fishing licenses and permits

- $\%$ of fishers with health insurance

- Farm worker housing - supply and conditions

- Pesticide exposure of farmworkers and families

- Farmworker pesticide poisonings

- Education and training programs for farmworkers and families

- Programs to assist food entrepreneurs - training, technical assistance, financing, facilities

- Job satisfaction ratings of farmers, farm workers, fishers and food industry workers (compared to others)

- $\%$ of food dollar paid to farmer - region food dollars, net farm earnings

- programs for low-income and minority access to land and food production skills. 


\section{Food Access}

Residents have easy access to culturally appropriate, healthy foods that are locally and sustainably produced.

- \% of population with access to Growing Spaces

- Average wait for Community Garden space

- Square feet of community garden space, number of spaces per capita

- Apartments with garden space/program

- Zoning requirements for garden space

- \# of farmers' markets

- \% of residents with convenient access to Farmers' Markets

- $\%$ of Farmers' Markets accepting FMNP coupons, senior FM coupons and food stamps

- $\%$ of residents with convenient access to Full-service markets or distance (and distance distribution) from eaters to nearest full-service food store

- Convenience stores per capita

- Food access by density, income, ethnicity, transit, accessibility for households without vehicle

- \% of food markets meeting criteria for affordable, culturally appropriate, local, and sustainable

- Price comparability - local, sustainable, conventional

- $\%$ of farms with farm stands and/or u-pick 
- $\%$ of population food secure

- $\%$ of population in poverty (or eligible for food stamps and other programs)

- $\%$ of eligible population receiving food stamps - participation rate

- \% of eligible population in WIC program

- \% of eligible children enrolled in school meal program

- Location of food stamp acceptance to food stamp users

- Distance/time/wait for food stamp and wic?

- Gleaning programs - \# of participants, pounds gleaned

- Persons served by food bank/pantry and \% of population served by food bank/pantry

- Number of gleaning programs, pounds, participants

- \% of restaurants serving local and sustainable ingredients

- $\%$ of food sales to restaurants that are local and sustainable

- $\%$ of governmental and non-governmental institutions purchasing local and sustainable ingredients

- $\%$ of food sales to governmental and non-governmental institutions that are local and sustainable

- $\%$ of schools with (and \% of students in schools with) Farm to School Programs. 
Food Choices Support Personal and Community Health

Residents have the information necessary to make food choices that support economic, environmental, and human health, and the power to participate in food policy decisions.

- Incidence of overweight and obesity

- Incidence of diet related diabetes

- Per capita daily servings of fruits and vegetables

- $\%$ of food and health related surveys with questions pertinent to community food systems

- \% infants breastfed to one year

- $\%$ of schools with food based education program

- $\%$ of students graduating with food based education

- $\%$ of schools with gardens

- $\%$ of schools with farm to school program

- Sales of Foods and beverages of Minimal Nutritional Value in schools

- Schools without corporate food or beverage advertising

- Schools without exclusive pouring rights

- \% of population aware of the term "food mile"

- $\%$ of population that can identify 5 regional, seasonal foods

- \% of population recognizing Buy Local branding 
- \# of agroecology/farm education centers

- $\%$ of residents with a food growing garden

- $\%$ of residents subscribing to a CSA

- Direct ag sales to public as \% of total ag sales

- Farmers' markets sales - per capita, \# of patrons, avg per patron, avg. \# of vendors, waiting list for vendors

- Number of Sustainable Community Food Events

- Family meal - avg. nights per week

- \$ spent on food - home and away

- The estimate piece. E.g., Average per capita consumption (ERS estimate * population) and what's grown; import data for state; greenhouse gas difference local/imported; economic multiplier local/imported.

- Supports cultural diversity

- Number of food policy councils at city, county, state level-diversity of membership

- Country of origin labeling

- GMO products labeled

- Labeling in restaurants - ingredients, origin of sources, and GMO

- Organic and sustainable acreage protected from genetic pollution/drift

- Organic and sustainable growers protected from patent infringement in cases of drift

- $\%$ of stores with slotting fees

- Concentration in food industry - production, processing, wholesale, retail, service. 